SJ Quinney College of Law, University of Utah Utah Law Digital Commons

Utah Law Faculty Scholarship

Utah Law Scholarship

4-2019

Trying Times: Conservation Easements and

Federal Tax Law (April 2019)

Nancy McLaughlin

Follow this and additional works at: https://dc.law.utah.edu/scholarship

Part of the Property Law and Real Estate Commons, and the Tax Law Commons 


\title{
TRYING TIMES
}

\section{CONSERVATION EASEMENTS}

AND

\author{
Federal TAX LAW
}

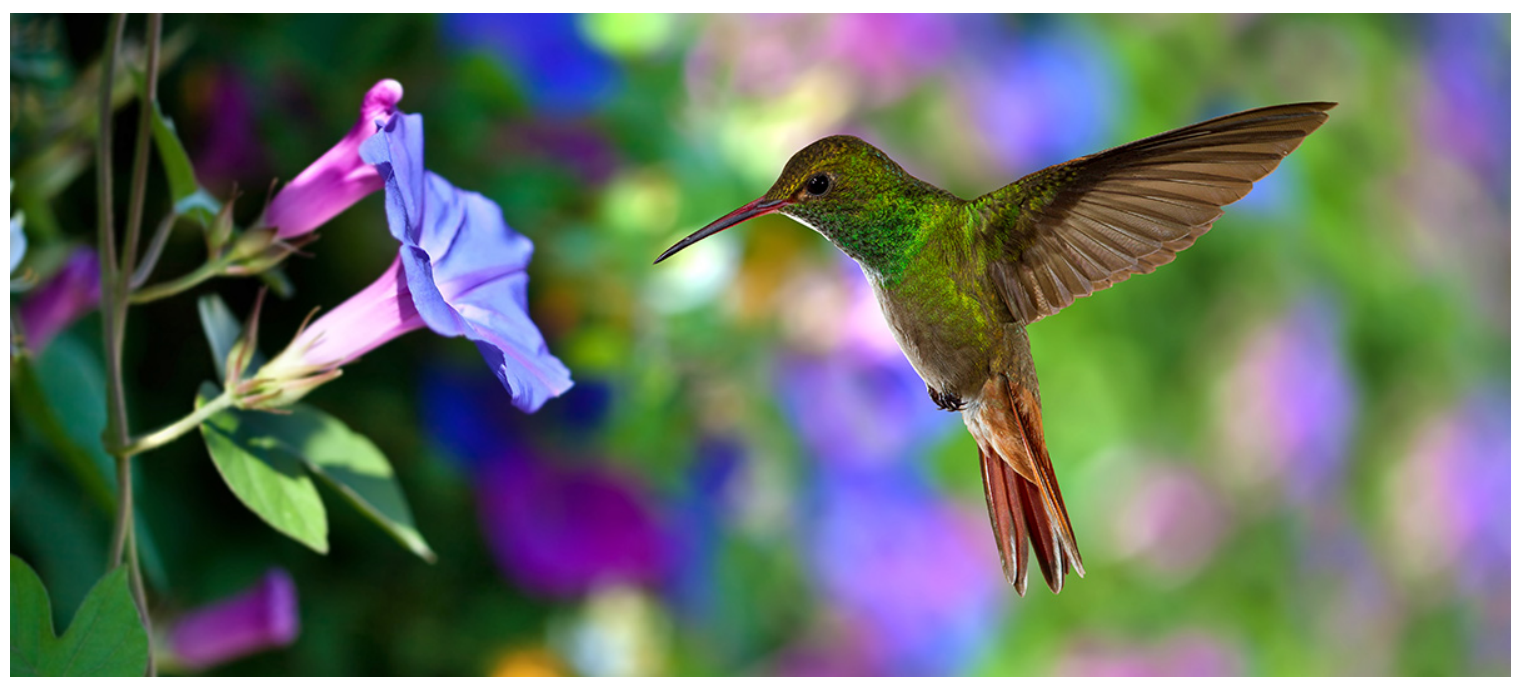

by

Nancy A. McLaughlin

Robert W. Swenson Professor of Law

University of Utah S.J. Quinney College of Law

Salt Lake City, Utah 84112

nancy.mclaughlin@law.utah.edu

(Last updated April 2019)

This outline was originally prepared by Nancy A. McLaughlin and Stephen J. Small for presentations at the Land Trust Alliance annual national conferences. This outline has since been substantially updated by Nancy A. McLaughlin.

This outline intended for educational and informational purposes only. Nothing in this outline or its Appendices is to be considered the rendering of legal advice. Readers are responsible for obtaining legal advice from their own legal counsel. 


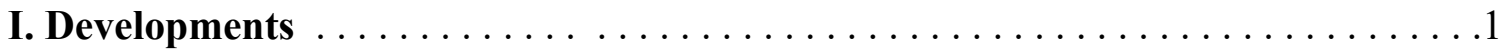

A. IRC $\S 170(\mathrm{~h})$ and Treasury Regulations. . . . . . . . . . . . . . . . 1

B. Washington Post Articles . . . . . . . . . . . . . . . . . . . . . . . . . . 1

C. IRS Notice $2004-41 \ldots \ldots \ldots \ldots \ldots \ldots . \ldots \ldots \ldots$

D. 2005 JCT Report . . . . . . . . . . . . . . . . . . . . . . . 2

E. Proposal to Penalize Charities that Fail to Enforce Restrictions . . . . . . . . . 2

F. 2005 SFC Report . . . . . . . . . . . . . . . . . . . . . . . . . . 2

G. 2005 IRS Testimony Before SFC . . . . . . . . . . . . . . . . 3

H. Pension Protection Act of $2006 \ldots \ldots \ldots \ldots \ldots \ldots \ldots \ldots \ldots \ldots \ldots \ldots \ldots \ldots \ldots$

I. DOJ Suit Against Trust for Architectural Easements . . . . . . . . . . . . . . .4

J. IRS Conservation Easement Audit Techniques Guide. . . . . . . . . . . . 5

K. IRS Form 990 Disclosures . . . . . . . . . . . . . . . . . . . . . . . . . . . . 5

L. Obama Administration Calls for Reform. . . . . . . . . . . . . 6

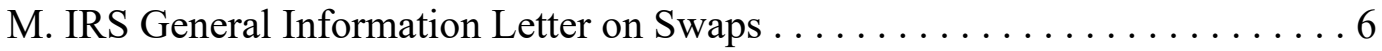

N. IRS General Information Letter on Extinguishment. . . . . . . . . . . . . 7

O. DOJ Suit Against Façade Easement Appraiser. . . . . . . . . . . . . . . . . . . . 7

P. IRS CCA on Conservation Easement Valuation. . . . . . . . . . . . . . . 7

Q. IRS Bars Appraisers From Valuing Easements for Five Years . . . . . . . . .8

R. Enhanced Incentives Made Permanent. . . . . . . . . . . . . . . . 8

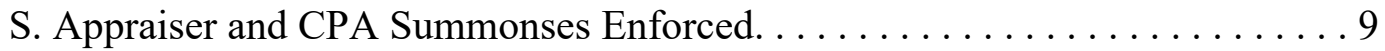

T. Treasury's 2016-2017 Priority Guidance Plan. . . . . . . . . . . . . . . . . 10

U. Syndicated Conservation Easement Transactions. . . . . . . . . . . . . 10

V. Case Law. . . . . . . . . . . . . . . . . . . . . . . . . . . . . 11

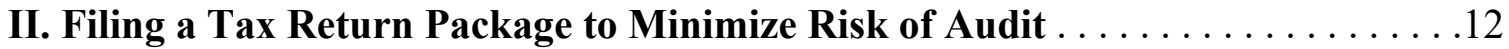

A. Correctly Drafted Conservation Easement Deed . . . . . . . . . . . . . . . 12

1. File Copy of Recorded Conservation Easement Deed . . . . . . . . . 12

2. Include Extensive Recitals . . . . . . . . . . . . . . . . . . . . . . . . . 12

3. "Exclusively for Conservation Purposes" Requirements . . . . . . . . 12

4. Extensive Reserved Rights . . . . . . . . . . . . . . . . . . . 13
a. Glass
b. Butler
c. Additional Case Law
d. Overarching Restriction
e. Liberal Construction Provision

5. Conservation Purposes Test .....................16
a. Turner
b. Glass
c. RP Golf I
d. Atkinson
e. PBBM-Rose Hill
f. Champions Retreat
g. Carroll
h. Herman I 


\section{i. Partita Partners I}

6. Extinguishments (Including Swaps) Require a Judicial Proceeding;

Building Areas; Amendment Clauses . . . . . . . . . . . . . . . . . . . 23

a. Carpenter I

b. Carpenter II

c. Mitchell II

d. Belk

e. Balsam Mountain

f. Bosque Canyon Ranch

g. Pine Mountain II

7. Reserved Development Rights: Regulations and Examples. ....... . 40

a. Treasury Regulations

b. Examples 3 and 4

8. Addressing Reserved Development Rights ............... 43

9. State Law Can Render Conservation Easements Nondeductible. . . . . 44

a. Federal Law Controls

b. Wachter: Termination in 99 Years Not So Remote as to be

Negligible.

10. Interaction Between Federal and State Law ..............45

11. Sample Restriction on Transfer and Extinguishment Provisions. . . . 48

12. Noncompliant Proceeds Clause. ....................... .50

a. Carroll

b. PBBM-Rose Hill

13. Noncompliant Deemed Approval Clause. ................ 55

14. Releasing Land With Transfer to "Comparable" Easement. . ...... 57

15. Reimbursement of Funders on Extinguishment . . . . . . . . . . . 58

16. Safe Harbor Provisions and Amnesty Period. . . . . . . . . . . . 59

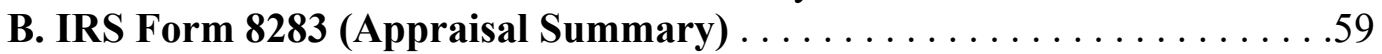

1. History . . . . . . . . . . . . . . . . . . . . . . . . . . 59

2. IRS Form 8283, Section B. .......................62

3. Supplemental Statement. .......................63 63

4. Special Rules for Façade Easement Donations. . . . . . . . . . . . . . 64

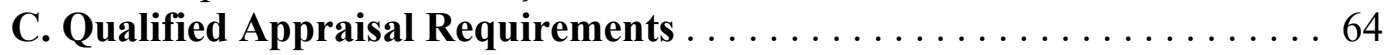

1. General Requirements ...........................64

a. Donors Should Strictly Comply

b. Collective Defects

c. Qualified Appraisals That Are Not Credible

d. Importance of Compliant Appraisals

2. Conservation Easement-Specific Valuation Rules............. 70

3. File Qualified Appraisal with Income Tax Return.............. 71

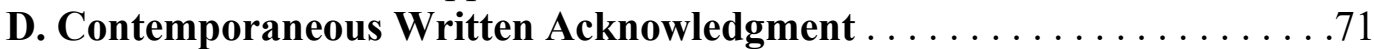

1. IRC $\S 170(f)(8)$ Requirements. . . . . . . . . . . . . . . . . . .71

2. Form 990 Filing Insufficient. . . . . . . . . . . . . . . 72

3. Substantial Compliance Doctrine Inapplicable. ............. 72

4. No Particular Form Required but Form 8283 is not a CWA. . . . . . . .72 72

5. Case Law Unpredictable. ......................... 73 
6. Safety Valve. .................................. 73

E. Compelling and Timely Baseline Documentation............ 73

F. Correct and Timely Lender Agreement (if applicable) . . . . . . . . . 76

1. Full Subordination. ........................... 76

a. Kaufman III

b. Palmolive I

2. Mortgages Must be Subordinated at Time of Donation.......... 78

a. Mitchell III

b. Minnick III

c. RP Golf III

G. So-Remote-As-To-Be-Negligible Does Not Cure Noncompliance . . . . . . .83

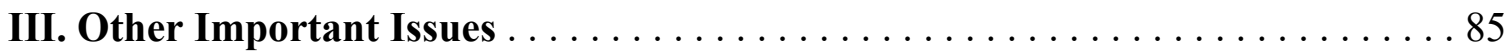

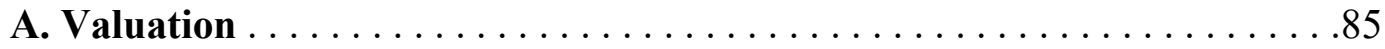

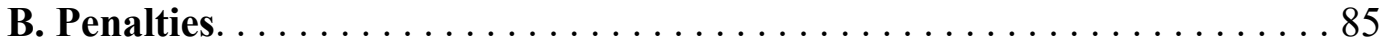

1. Penalty Provisions. . . . . . . . . . . . . . . . . . . . 85

2. Case Law. . . . . . . . . . . . . . . . . . . . . . . . . 85

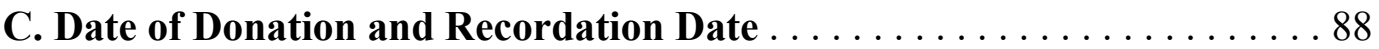

1. IRS Position on Year of Donation. . . . . . . . . . . . . . . . . .89

2. Case Law. . . . . . . . . . . . . . . . . . . . . . . . . . . . . 89

3. Finer Points of Delivery and Recording. ................ 92

D. Quid Pro Quo ................................ 92

1. Treasury Regulation Requirements. ..................92

2. Case Law. . . . . . . . . . . . . . . . . . . . . . . . . . . . .93

E. Side Agreements . . . . . . . . . . . . . . . . . . . . . . . 101

F. Donation by Term-Limited Lessee . . . . . . . . . . . . . . . . . . . . .102

G. "Qualified Farmer or Rancher". . . . . . . . . . . . . . . . . . . . . . . 104

H. Disguised Sales . . . . . . . . . . . . . . . . . . . . . . . . . 104

I. PLRs Recommending Revocation of Tax-Exempt Status. . . . . . . . 105

J. State Tax Credits . . . . . . . . . . . . . . . . . . . . . . . . . . . 107

Appendices

Appendix A: IRC § 170(h)

Appendix B: Treasury Regulation § 1.170A-14 (interpreting § 170(h))

Appendix C: Table of Deduction Cases

Appendix D: IRC $\S 170(f)(11)$

Appendix E: Final Treasury Regulations: Substantiation and Reporting Requirements

Appendix F: Form 8283 Supplemental Statement Example (Stephen J. Small)

Appendix G: Limited Amendment Provision Example (Stephen J. Small) 


\section{Developments}

\section{A. IRC $\$ 170(\mathrm{~h})$ and Treasury Regulations}

IRC $\S 170(\mathrm{~h})$ (attached as Appendix A), which authorizes a federal charitable income tax deduction for the donation of a conservation easement meeting specific requirements, was enacted in 1980. Treasury Regulations interpreting $\S 170(\mathrm{~h})$ (attached as Appendix B) were issued in 1986. The Treasury Regulations are based, in large part, on the detailed Senate Report describing $§ 170(\mathrm{~h})$ (the legislative history). ${ }^{1}$

\section{B. Washington Post Articles}

In May 2003, the Washington Post published a series of articles questioning some of the practices of The Nature Conservancy. ${ }^{2}$ In December of that same year, the Washington Post published a follow-up article describing allegedly abusive conservation easement donation transactions involving "wildly exaggerated" easement appraisals and developers who received "shocking" tax deductions for donating conservation easements encumbering golf course fairways or otherwise undevelopable land. ${ }^{3}$

In December 2004, the Washington Post published a second series of articles alleging abuses in the facade easement donation context. ${ }^{4}$ The articles described a surge in facade easement donations that coincided with the emergence of for-profit facilitators and nonprofit organizations that have "taken in millions of dollars for processing paperwork and monitoring the easements." The articles also noted that facade easements often merely duplicate restrictions already imposed by local law and fail to decrease the value of the buildings they encumber, making tax deductions based on a $10 \%$ to $15 \%$ reduction in the value of the properties unwarranted. One promoter reportedly told property owners they would receive tax breaks for a drop in their property values, but stressed that there would be no actual decline; that "[i]t's a paper concept."

\section{IRS Notice 2004-41}

In June 2004, the IRS issued Notice $2004-41,{ }^{6}$ which states that the IRS is aware that taxpayers who transfer conservation easements to charitable organizations or make payments to charitable organizations in connection with a purchase of real property from the organization may be improperly claiming charitable deductions under $\S 170$. The

\footnotetext{
${ }^{1}$ S. Rep. No. 96-1007 (1980), $96^{\text {th }}$ Cong., $2^{\text {nd }}$ Sess. 1980, 1980-2 C.B. 599, available at 1980 IRB LEXIS 2362 or 1980 WL 12915.

${ }^{2}$ See David B. Ottaway \& Joe Stephens, Nonprofit Land Bank Amasses Billions, Wash. Post, May 4, 2003, at A1; Joe Stephens \& David B. Ottaway, How a Bid to Save a Species Came to Grief, WASH. Post, May 5, 2003, at A1; Joe Stephens \& David B. Ottaway, Nonprofit Sells Scenic Acreage to Allies at a Loss; Buyers Gain Tax Breaks with Few Curbs on Land Use, WASH. Post, May 6, 2003, at A1.

${ }^{3}$ Joe Stephens \& David B. Ottaway, Developers Find Payoff in Preservation, WAsh. Post, Dec. 21, 2003 , at A1.

${ }^{4}$ See Joe Stephens, For Owners of Upscale Homes, Loophole Pays; Pledging to Retain the Facade Affords a Charitable Deduction, WASh. Post, Dec. 12, 2004, at A1 [Loophole Pays]; Joe Stephens, Local Laws Already Bar Alterations; Intervention by Trusts Is Rare for Preservation, WASH. Post, Dec. 12, 2004, at A15; Joe Stephens, Tax Break Turns Into Big Business, WASH. Post, Dec. 13, 2004, at A1.

${ }^{5}$ See Loophole Pays, supra note 4.

${ }^{6}$ Available at https://www.irs.gov/irb/2004-28 IRB\#NOT-2004-41.
} 
Notice warned that the IRS intends to disallow improper deductions and impose penalties and excise taxes on taxpayers, promoters, and appraisers involved in such transactions.

\section{2005 JCT Report}

In January 2005, the Joint Committee on Taxation (JCT) issued a report to Congress recommending, among other things, that:

1. the federal charitable contribution deduction offered to conservation easement donors be eliminated with respect to easements encumbering property on which the donor maintains a personal residence,

2. the deduction be substantially reduced in all other cases, and

3. new standards be imposed on appraisers and appraisals with regard to the valuation of easements. ${ }^{7}$

\section{E. Proposal to Penalize Charities that Fail to Enforce Restrictions}

In March 2005, the JCT published a Description of Revenue Provisions Contained in the President's Fiscal Year 2006 Budget Proposal, one of which was to impose significant penalties on a charity that removes or fails to enforce conservation easement restrictions, or transfers an easement without ensuring that the conservation purposes will be protected in perpetuity. ${ }^{8}$

\section{F. 2005 SFC Report}

In June 2005, the Senate Finance Committee (SFC) held a hearing on the federal tax incentives available with respect to conservation easement donations. In connection with that hearing, the SFC issued a report in which it recommended numerous reforms, including:

1. revocation of the tax-exempt status of conservation organizations that regularly and continuously fail to monitor the conservation easements they hold (or the suspension of the ability of such organizations to accept tax-deductible contributions),

2. implementation of an accreditation program for conservation organizations acquiring easements,

3. limiting charitable contribution deductions for certain small easement donations and providing the IRS with the authority to pre-approve deductions for such donations, and

4. IRS issuance of guidance regarding how a conservation organization can establish that it is appropriately monitoring the easements it holds. ${ }^{9}$

\footnotetext{
${ }^{7}$ Options to Improve Tax Compliance and Reform Tax Expenditures, prepared by the Joint Committee on Taxation, JCS2-05, 281 (Jan. 27, 2005).

${ }^{8}$ Description of Revenue Provisions Contained in the President's Fiscal Year 2006 Budget Proposal, prepared by Joint Committee on Taxation, JCS-3-05, 239-41 (March 2005).

${ }^{9}$ Report of Staff Investigation of The Nature Conservancy (Volume I), U.S. Senate Committee on Finance, Executive

Summary 10-11 (June 2005), available under "Library," then "Committee Prints" at http://finance.senate.gov/.
} 
The Senate Finance Committee report also expresses concern regarding amendments to conservation easements. The report explains that " $[\mathrm{m}]$ odifications to an easement held by a conservation organization may diminish or negate the intended conservation benefits, and violate the present law requirements that a conservation restriction remain in perpetuity." 10 The report notes that modifications made to correct ministerial or administrative errors are permitted under present federal tax law. ${ }^{11}$ But the report expresses concern with regard to "trade-off" amendments, which both negatively impact and further the conservation purpose of an easement, but on balance are arguably either neutral with respect to or enhance such purpose. ${ }^{12}$ The report provides, as an example, an amendment to an easement that would permit the owner of the encumbered land to construct a larger home in exchange for restrictions further limiting the use of the land for agricultural purposes. ${ }^{13}$ The report explains that trade-off amendments "may be difficult to measure from a conservation perspective," and that the "weighing of increases and decreases [in conservation benefits] is difficult to perform by [the holder] and to assess by the IRS." 14

\section{G. 2005 IRS Testimony Before SFC}

In his testimony before the Senate Finance Committee in June 2005, then IRS Commissioner of the Tax-Exempt and Government Entities Division discussed steps the IRS was taking to enforce the law in this area, including:

1. modifications to IRS Forms 1023, 990, and 8283,

2. the formation of a special cross-functional team to "attack all aspects of the problem of conservation easements," and

3 . increased audits of easement donors. ${ }^{15}$

\section{H. Pension Protection Act of 2006}

To combat abuses, the Pension Protection Act of 2006, ${ }^{16}$ among other things:

1. revised the rules in $\S 170(\mathrm{~h})$ with respect to contributions of certain types of façade easements,

2. provided statutory definitions of the terms "qualified appraiser" and "qualified appraisal" in IRC $\S 170(f)(11)$, and

3. lowered the thresholds for accuracy-related penalties and made the gross valuation misstatement penalty with regard to charitable contributions a strict liability penalty.

At the same time, the Pension Protection Act increased the tax benefits offered to conservation easement donors for donations made in 2006 and 2007 by making the percentage limitations and carry-forward periods applicable to resulting charitable

\footnotetext{
${ }^{10} I d$., Executive Summary 9.

${ }^{11} I d$., Executive Summary 9, n. 20.

${ }^{12}$ See id., at Pt. II 5.

${ }^{13}$ See id.

${ }^{14} \mathrm{Id}$.

15 The testimony is available at http://www.finance.senate.gov/hearings/hearing/?id=e821cece-d9eb-1c66-4b9eb4a6602a54f4.

${ }^{16}$ Pub. L. No. 109-280, 120 Stat. 780.
} 
deductions more favorable. ${ }^{17}$ These enhanced incentives were repeatedly temporarily extended and then made permanent in $2015 .^{18}$

\section{DOJ Suit Against Trust For Architectural Easements}

In June 2011, the Department of Justice (DOJ) filed a lawsuit against the Trust for Architectural Easements ("TAE"). ${ }^{19}$ The lawsuit alleged, among other things, that TAE made false and fraudulent statements to prospective donors about the tax benefits available for donating façade easements, steered donors to appraisers who had been coached by it to go along with its questionable practices, helped donors to claim deductions before donations were final, and allowed donors to terminate easements they had already granted. ${ }^{20}$ In July 2011, a U.S. District Court Judge issued a permanent injunction against TAE settling the case. ${ }^{21}$ The injunction permanently prohibits TAE from engaging in what the federal government said were abusive and illegal practices. The injunction bars TAE from, among other things:

1. representing to prospective donors and others that the IRS has established a "safe harbor" for the value of a donated façade easement equal to 10 to $15 \%$ of the subject building's value,

2. participating in the appraisal process for a conservation easement in any regard, including recommending or referring donors to an appraiser or TAE's preferred list of appraisers,

3. accepting easements that lack a conservation purpose or do not satisfy the "protected in perpetuity" requirement of $\S 170(\mathrm{~h})$, and

4. requesting fees or cash donations tied to a percentage of the estimated value of the easement or the deduction to be claimed with regard to the easement's donation.

TAE was also ordered to pay an independent monitor for two years to ensure that it complied with the injunction. ${ }^{22}$

\footnotetext{
${ }^{17}$ Before 2006, as a general rule, a property owner could claim the deduction generated by an easement donation to the extent of $30 \%$ of the property owner's adjusted gross income (AGI) in each of the year of the donation and the following five years. Based on changes made in 2006, which were temporary and repeatedly extended temporarily, easement donors were permitted to claim the resulting deduction to the extent of $50 \%$ of the donor's AGI in the year of the donation and the following 15 years, or, for qualifying farmer and rancher donations, $100 \%$ of the donor's AGI for the 16-year period.. See Technical Explanation Of H.R. 4, The "Pension Protection Act Of 2006," prepared by the Joint Committee on Taxation, JCX-38-06 (August 3, 2006) [hereinafter JCT Explanation of Pension Protection Act of 2006].

${ }^{18}$ For guidance on deductions by individuals for qualified conservation contributions, see IRS Notice 2007-50.

${ }^{19}$ Complaint for Permanent Injunction and Other Relief, U.S. v. McClain, Civ. No. 11-1087 (U.S. Dist. Ct. D.C. June 14, 2011). TAE was formerly known as the National Architectural Trust or "NAT."

${ }^{20}$ Id. See also Janet Novack, Feds Sue Trust Over Historic Easement Tax Breaks, Taxing Matters, ForBES, June 16, 2011.

${ }^{21}$ Stipulated Order of Permanent Injunction, U.S. v. McClain, Civ. No. 11-1087 (U.S. Dist. Ct. D.C. July, 15, 2011) (TAE agreed to the settlement without admitting any wrongdoing).

${ }^{22}$ Id. See also D.C. Federal Court Bars Company from Promoting Alleged Tax Scheme Involving Improper Easements on Historic Buildings, Department of Justice Press Release (July 18, 2011); Joe Stephens, Judge bars D.C. charity from promoting 'façade easement' tax deductions, WASH. Post, July 19, 2011.
} 


\section{J. IRS Conservation Easement Audit Techniques Guide}

The IRS issued a Conservation Easement Audit Techniques Guide in 2012 (last revised in Jan. 2018). ${ }^{23}$ The Guide is not an official pronouncement of the law or the position of the IRS, and it cannot be used, cited, or relied upon as such. The Guide nonetheless provides a detailed summary of many of the requirements that must be met to be eligible for a deduction for the donation of a conservation easement under $\S 170(\mathrm{~h})$ and includes numerous examples. The Guide also alerts readers to various issues that IRS Examiners will consider when reviewing a taxpayer's tax return claiming a $\S 170(\mathrm{~h})$ deduction.

\section{K. IRS Form 990 Disclosures}

IRC $\S 501(c)(3)$ organizations — as most land trusts are - must file an IRS Form 990 (Return of Organization Exempt From Income Tax) each year. Schedule D to IRS Form 990 requires a charitable organization holding a conservation easement to provide certain information, including:

1. the total number of conservation easements held at the end of the year;

2. the total acreage restricted by such easements;

3. the number of easements modified, transferred, released, or extinguished, by the organization during the taxable year;

4. whether the organization has a written policy regarding the monitoring and enforcement of easements;

5. the total number of hours devoted to monitoring, enforcing, and inspecting conservation easements during the tax year; and

6. the expenses incurred during the tax year to monitor, inspect, and enforce easements.

For each easement modified, transferred, released, or extinguished, in whole or in part, the organization must explain the changes in a Supplemental Statement to Schedule D. The Instructions for Schedule D explain:

1. an easement is released, extinguished, or terminated when, among other things, all or part of the property subject to the easement is removed from the protection of the easement in exchange for cash or the protection of some other property;

2. the use of synonyms does not avoid the application of the reporting requirement (e.g., calling an action a "swap" or a "boundary line adjustment" does not mean the action is not also a modification, transfer, or extinguishment); and

3. "[t]ax exemption may be undermined by the modification, transfer, release, extinguishment, or termination of an easement."

\footnotetext{
${ }^{23}$ The IRS Conservation Easement Audit Techniques Guide is available at https://www.irs.gov/businesses/smallbusinesses-self-employed/audit-techniques-guides-atgs.
} 


\section{Obama Administration Calls for Reform}

In its Revenue Proposals for fiscal year's 2013 through 2017, ${ }^{24}$ the Obama Administration proposed a variety of reforms to curb abuses in the conservation easement deduction context, including:

1. elimination of the charitable deduction for contributions of conservation easements on golf courses;

2. disallowance of the deduction for the value of a façade easement associated with forgone upward development above a historic building;

3. requiring all conservation easements to further a clearly delineated Federal or authorized state or tribal governmental policy and yield a significant public benefit; 4. requiring donors to provide detailed information about the conservation purposes and public benefit of contributed easements;

5. requiring donees to meet minimum standards, attest to the accuracy of donor representations to the IRS, and electronically report information about donated easements, and

6. subjecting donees to loss of "eligible donee" status and donees and their managers to penalties for overvalued easements or easements that do not further eligible conservation purposes.

The Administration also proposed to pilot a new tax credit for conservation easement donations "as an alternative" to the $\S 170(\mathrm{~h})$ deduction.

\section{IRS General Information Letter on Swaps}

In a March 2012 Information Letter, the IRS advised that conservation easements that are subject to swaps other than in the very limited situation of a swap that meets the extinguishment and proceeds requirements of Treasury Regulation $\S 1.170 \mathrm{~A}-14(\mathrm{~g})(6)$ are not deductible. ${ }^{25} \mathrm{~A}$ "swap" is defined as the removal of some or all of the originally protected property from the terms of the original deed of conservation easement in exchange for either the protection of some other property or the payment of cash.

\footnotetext{
${ }^{24}$ See General Explanations of the Administration's Fiscal Year 2013 Revenue Proposals, Treas. Dep't 140 (February 2012), available at http://www.treasury.gov/resource-center/tax-policy/Documents/General-Explanations-FY2013.pdf; General Explanations of the Administration's Fiscal Year 2014 Revenue Proposals, Treas. Dep't 161-162 (April 2013), available at http://www.treasury.gov/resource-center/tax-policy/Documents/General-Explanations-FY2014.pdf; General Explanations of the Administration's Fiscal Year 2015 Revenue Proposals, Treas. Dep't 193-196 (March 2014), available at http://www.treasury.gov/resource-center/tax-policy/Documents/General-Explanations-FY2015.pdf; General Explanations of the Administration's Fiscal Year 2016 Revenue Proposals, Treas. Dep't 188-192 (Feb. 2015), available at http://www.treasury.gov/resource-center/tax-policy/Documents/General-Explanations-FY2016.pdf; General Explanations of the Administration's Fiscal Year 2017 Revenue Proposals, available at https://www.treasury.gov/resource-center/tax-policy/Documents/General-Explanations-FY2017.pdf.

${ }^{25}$ Information Letter from Karin Goldsmith Gross, Senior Technician Reviewer, IRS (March 5, 2012), available at http://www.irs.gov/pub/irs-wd/12-0017.pdf.
} 


\section{N. IRS General Information Letter on Extinguishment}

In a September 2012 Information Letter, the IRS advised that, while state law may provide a means for extinguishing a conservation easement for state law purposes, the requirements of $\S 170(\mathrm{~h})$ and the Treasury Regulations, including Treasury Regulation $\S 1.170 \mathrm{~A}-14(\mathrm{~g})(6)$ (the judicial extinguishment and division of proceeds regulation), must nevertheless be satisfied for a contribution to be deductible for federal income tax purposes. ${ }^{26}$

\section{O. DOJ Suit Against Facade Easement Appraiser}

In January 2013, the United States filed a complaint in District Court against an appraiser and the company he owned with his wife. ${ }^{27}$ The complaint alleged, among other things, that the appraiser had appraised more than ninety conservation easements for purposes of the deduction under $\S 170(\mathrm{~h})$ and had repeatedly and continually made material and substantive errors, distorted data, and provided misinformation and unsupported personal opinions in the appraisals to significantly inflate the value of the easements for federal deduction purposes. The complaint also alleged that the appraiser attempted to obstruct IRS enforcement efforts by claiming not to have any work files for his appraisal reports, which professional standards require that an appraiser maintain. "This sort of abuse of a high-dollar charitable contribution deduction," stated the complaint, "inspires contempt for the system of honest, voluntary income tax reporting."

In February 2013, the District Court issued an Agreed Order of Permanent Injunction that, among other things, (i) barred the appraiser and the company from preparing any kind of appraisal report or otherwise participating in the appraisal process for any property relating to federal taxes and (ii) ordered the appraiser and the company to provide to counsel for the United States a list of clients for whom they prepared appraisal reports for tax purposes on or since November 1, 2009. ${ }^{28}$

\section{P. IRS CCA on Conservation Easement Valuation}

In August 2012, the IRS Office of Chief Counsel published helpful guidance on valuing conservation easements in accordance with some of the more technical requirements of Treasury Regulation $\S 1.170 \mathrm{~A}-14(\mathrm{~h})(3)(\mathrm{i}) .{ }^{29}$ The Chief Counsel Advice (CCA) specifically addresses the "contiguous parcel" and "enhancement" rules, and provides twelve examples illustrating the application of those rules.

\footnotetext{
${ }^{26}$ Information Letter from Karin Goldsmith Gross, Senior Technician Reviewer, IRS (Sept. 18, 2012), available at http://bit.ly/1VMfimR.

${ }^{27}$ Complaint for Permanent Injunction and Other Relief, U.S. v. Ehrmann et al., Civ. No. 1:13-cv-214 (N.D. Ohio, Jan. 30, 2013).

${ }^{28}$ Agreed Order of Permanent Injunction, U.S. v. Ehrmann, Civ. No. 1:13-cv-00214-DAP (N.D. Ohio Feb. 12, 2013) (the appraiser and company agreed to the settlement without admitting any wrongdoing). See also Ohio Federal Court Bars Appraiser of Historic-Preservation Easements, Department of Justice Press Release (Feb. 13, 2013).

29 IRS Chief Counsel Advice 201334039 (released Aug. 23, 2012), available at http://www.irs.gov/pub/irswd/1334039.pdf. See also IRS on Conservation Easement Valuation, at

$\underline{\text { http://lawprofessors.typepad.com/nonprofit/2014/09/irs-on-conservation-easement-appraisals.html. }}$
} 


\section{Q. IRS Bars Appraisers from Valuing Easements for Five Years}

In March 2014, the IRS announced that its Office of Professional Responsibility (OPR) had entered into a settlement agreement with a group of appraisers from the same firm accused of aiding in the understatement of federal tax liabilities by overvaluing facade easements for charitable donation purposes. ${ }^{30}$ To value facade easements, the appraisers had simply multiplied the "before" value of the subject property by a fixed percentage, generally $15 \%$. Under the settlement agreement, the appraisers admitted to violating relevant sections of Circular 230. According to the Director of OPR:

Appraisers need to understand that they are subject to Circular 230, and must exercise due diligence in the preparation of documents relating to federal tax matters. Taxpayers expect advice rendered with competence and diligence that goes beyond the mere mechanical application of a rule of thumb based on conjecture and unsupported conclusions.

The appraisers agreed to a five-year suspension of valuing facade easements and undertaking any appraisal services that could subject them to penalties under the Internal Revenue Code. The appraisers also agreed to abide by all applicable provisions of Circular 230.

\section{R. Enhanced Incentives Made Permanent}

On December 18, 2015, President Obama signed into law the Protecting Americans from Tax Hikes Act of 2015 (the PATH Act). ${ }^{31}$ Before the PATH Act, as a general rule, a property owner could claim the deduction generated by an easement donation to the extent of $30 \%$ of the property owner's adjusted gross income (AGI) in each of the year of the donation and the following five years. Based on changes made in 2006, which were temporary and repeatedly extended temporarily, easement donors were permitted to claim the resulting deduction to the extent of $50 \%$ of the donor's AGI in the year of the donation and the following 15 years, or, for qualifying farmer and rancher donations, $100 \%$ of the donor's AGI for the 16-year period. The PATH Act made these favorable rules for easement donations permanent. In addition, beginning in 2016, the Act allows an Alaska Native Corporation donating a conservation easement with respect to certain lands to claim the resulting deduction to the extent of $100 \%$ of taxable income in the year of the donation and the following 15 years. Accordingly, farmers, ranchers, and Alaska Native Corporations that make qualifying easement donations can potentially avoid paying any federal income tax for up to 16 years. The PATH Act made the enhanced incentives

\footnotetext{
${ }^{30}$ IRS, IRS Bars Appraisers from Valuing Facade Easements for Federal Tax Purposes for Five Years, IR-2014-31 (March 19, 2014), available at http://www.irs.gov/uac/Newsroom/IRS-Bars-Appraisers-from-Valuing-FacadeEasements-for-Federal-Tax-Purposes-for-Five-Years.

${ }^{31}$ See Technical Explanation of the Protecting Americans From Tax Hikes Act of 2015, prepared by the Joint Committee on Taxation, JCX-144-15 (Dec. 17, 2015).
} 
permanent without implementing any reforms proposed by the Treasury or others to curb abuses. $^{32}$

The incentives for conservation easement donations are complex. It is important to have a competent tax professional who has up to date software estimate the potential tax benefits. Neither the donor nor the donee should attempt to guess or estimate the potential benefits.

\section{S. Appraiser and CPA Summonses Enforced}

In April 2016, a U.S. District Judge for the Northern District of Georgia granted the IRS's petition to enforce a summons served on an appraiser. ${ }^{33}$ The summons requested, among other things, all documents reflecting the customers for whom the appraiser prepared or approved conservation or historic easement appraisals during the period beginning January 1,2010 , through the present, and all appraisal work files for such appraisals. The judge found that the summons had a legitimate purpose (to determine whether the appraiser had improperly appraised conservation easements), the summons was not overbroad, and the IRS was not acting in bad faith.

In June 2016, a U.S. District Judge for the Northern District of Georgia granted the IRS's petition to enforce a summons served on a certified public accountant (CPA) ${ }^{34}$ Among other things, the IRS was seeking client files, tax returns, and supporting documentation for federal tax returns prepared by the CPA for tax years 2010-2012 that were either conservation easement partnership returns or federal income tax returns where the client claimed a charitable deduction arising from a conservation easement. Quoting the Eleventh Circuit, which was quoting the Supreme Court, the judge explained, in part, that:

"[T]he Government depends upon the good faith and integrity of each potential taxpayer to disclose honestly all information relevant to tax liability.... The purpose of ... [a summons] is not to accuse, but to inquire. Although such investigations unquestionably involve some invasion of privacy, they are essential to our selfreporting system, and the alternatives could well involve far less agreeable invasions of house, business, and records."

\footnotetext{
32 See, e.g., Roger Colinvaux, Conservation Easements: Design Flaws, Enforcement Challenges, and Reform, 2013 UTAH LAw ReVIEW 755; Wendy C. Gerzog, Alms to the Rich: The Façade Easement Deduction, 34 VA. TAX REV. 229 (2014); Daniel Halperin, Incentives for Conservation Easements: The Charitable Deduction or a Better Way, 74 LAW \& Contemp. Probs. 29 (2011); Nancy A. McLaughlin, Conservation Easements and the Valuation Conundrum, 19 FLA. TAX REV. 225 (2016); Nancy A. McLaughlin, Extinguishing and Amending Tax-Deductible Conservation Easements: Protecting the Federal Investment After Carpenter, Simmons, and Kaufman, 13 Fla. TAx Rev. 217 (2012); Jeff Pidot, Reinventing Conservation Easements: A Critical Examination and Ideas for Reform (Lincoln Institute of Land Policy 2005). See also Nancy A. McLaughlin, Tax-Deductible Conservation Easements and the Essential Perpetuity Requirements, 37 Va. Tax Rev. 1 (2017).

${ }^{33}$ U.S. v. Clower, 2016 WL 3144048 (N.D. Ga. Apr. 29, 2016), adopting Judge's Report and Recommendation in U.S. v. Clower, 2016 WL 3129451 (N.D. Ga. March 22, 2016), aff'd U.S. v. Clower, 666 Fed.Appx. 869 (11 ${ }^{\text {th }}$ Cir. 2016) (unpublished). See also U.S. v. Richey, 632 F.3d 559 ( $9^{\text {th }}$ Cir. 2011) (holding that IRS summons seeking production of appraiser's work file was issued in good faith and the file was not protected from disclosure by the work-product doctrine, but remand was required to determine whether some of the contents of file were protected by attorney-client privilege); Stern v. U.S., 2010 WL 7096092 (D. Idaho 2010).

${ }^{34}$ U.S. v. Greenberger, 2016 WL 3912060 (N.D. Ga. June 21, 2016), adopting Judge's Report and Recommendation in U.S. v. Greenberger, 2016 WL 391206 (N.D. Ga. Jan. 11, 2016). See also Greenberger v. IRS, 283 F.Supp.3d 1354 (N.D. Ga. 2017), in which the court denied Greenberger's FOIA request seeking the IRS's investigation file concerning him.
} 


\section{T. Treasury's 2016-2017 Priority Guidance Plan}

The Treasury's 2016-2017 Priority Guidance Plan contained projects that were priorities for allocation of the resources of its offices from July 2016 through June $2017 .{ }^{35}$ One of the listed projects was "[g]uidance under $\$ 170$ regarding charitable contributions of conservation easements."

\section{U. Syndicated Conservation Easement Transactions}

In December 2016, the IRS issued Notice 2017-10, which identifies certain conservation easement donation transactions involving pass-through entities as "listed" (or tax avoidance) transactions and requires certain parties to such transactions to make disclosures to the IRS. The Notice identifies the following transactions and those substantially similar thereto as "listed" transactions: if an investor received oral or written promotional materials that offered prospective investors in a pass-through entity the possibility of a deduction that equals or exceeds two and one-half times the investor's investment. Donees described in $\S 170(\mathrm{c})$ are not treated as parties to, participants in, or material advisors with respect to such transactions for purposes of the Notice. ${ }^{36}$

In May 2017, an economist at the Brookings Institution published a report discussing problems and abuses in the conservation easement donation context, including grossly inflated easement appraisals and easements that do not fulfill bona fide conservation purposes. ${ }^{37}$ In December 2017, the economist published a follow-up piece on abuses that explains that the deduction program is costing billions of dollars annually in terms of lost revenue and now ranks among the largest federal environmental and land management programs in the U.S. budget. ${ }^{38}$

In September 2018, the IRS announced Syndicated Conservation Easement Transactions as one of its compliance campaigns. ${ }^{39}$

In December 2018, the DOJ filed a complaint in U.S. District Court for the Northern District of Georgia seeking an order to shut down certain promoters of syndicated donation

\footnotetext{
${ }^{35}$ Department of the Treasury, 2016-2017 Priority Guidance Plan, available at https://www.irs.gov/pub/irs-utl/20162017 pgp initial.pdf.

${ }^{36}$ See also Notice 2017-29; Notice 2017-58.

37 Adam Looney, Charitable Contributions of Conservation Easements, Brookings Institution 5 (May 2017), https://www.brookings.edu/wp-content/uploads/2017/05/looney conservationeasements.pdf.

${ }_{38}$ Adam Looney, Estimating the Rising Costs of a Surprising Tax Shelter: The Syndicated Conservation Easement, Brookings Institution (Dec. 20, 2017), https:/www.brookings.edu/blog/up-front/2017/12/20/estimating-the-rising-costof-a-surprising-tax-shelter-the-syndicated-conservation-easement/. For additional reporting on syndicated transactions, see, e.g., Peter Elkind, The Billion-Dollar Loophole, ProPublica (Dec. 20, 2017), https://www.propublica.org/article/conservation-easements-the-billion-dollar-loophole; Richard Rubin, Thousands of Investors Got Big Tax Breaks for Land-Rights Donations, IRS Finds, Wall St. J. (Mar. 14, 2018).

${ }^{39}$ See IRS Announces the Identification and Selection of Five Large Business and International Compliance Campaigns (Sept. 10, 2018), https://www.irs.gov/businesses/irs-announces-the-identification-and-selection-of-five-large-businessand-international-compliance-campaigns-0. This campaign is intended to encourage taxpayer compliance and ensure consistent treatment of similarly situated taxpayers by ensuring the easement contributions meet the legal requirements for a deduction and the fair market values are accurate.
} 
transactions operating out of Georgia and require them to disgorge all profits related to such transactions, plus interest. ${ }^{40}$

In March 2019, the IRS announced that syndicated deals are on their annual "Dirty Dozen" list of Tax Scams to avoid. ${ }^{41}$ The Senate Finance Committee launched an investigation into the potential abuse of syndicated conservation easement transactions. ${ }^{42}$ In addition, a bipartisan bill was introduced into Congress that would limit deductions under $\S 170(\mathrm{~h})$ for certain easement contributions made by partnerships. ${ }^{43}$ The bill is designed to curb abuses by promoters of syndicated deals, while still allowing partners in family or other legitimate conservation partnerships to benefit from the deduction.

\section{Case Law}

Since 2005, the courts have decided more than 70 cases involving challenges to deductions claimed with respect to easement donations. More than 100 opinions have been issued in these cases, some of which were appealed, had a motion for reconsideration filed, or resulted in opinions addressing different issues. Appendix $\mathrm{C}$ lists the cases and opinions as of April 2019. The cases and opinions are referred to in this outline by case name and numerical designation (e.g., Belk III, Carpenter I, Palmer Ranch II).

\footnotetext{
${ }^{40}$ See DOJ, Office of Public Affairs, Justice Department Sues to Shut Down Promoters of Conservation Easement Tax Scheme Operating out of Georgia (Dec. 19, 2018), https://www.justice.gov/opa/pr/justice-department-sues-shut-downpromoters-conservation-easement-tax-scheme-operating-out; Complaint, U.S. v. Zak et al., Case 1:18-cv-05774-AT (N.D. Ga., Dec. 18, 2018). See also Jay Adkisson, DOJ Sues to Shut Down Conservation Easement Tax Shelter Promoters, Forbes, Personal Finance (Dec. 20, 2018), https://goo.gl/FD5vSP.

${ }^{41}$ IRS, Abusive tax shelters, trusts, conservation easements make IRS' 2019 "Dirty Dozen" list of tax scams to avoid, (March 19, 2019), https://www.irs.gov/newsroom/abusive-tax-shelters-trusts-conservation-easements-make-irs-2019dirty-dozen-list-of-tax-scams-to-avoid.

${ }_{42}$ U.S. Senate Committee on Finance, Grassley, Wyden Launch Probe of Conservation Tax Benefit Abuse, March 27, 2019, https://www.finance.senate.gov/chairmans-news/grassley-wyden-launch-probe-of-conservation-tax-benefitabuse.

${ }^{43}$ U.S. Congressman Mike Thompson, Thompson and Kelly Introduce Legislation to Help Stop Abuse of Conservation Tax Incentive, March 28, 2019, https://mikethompson.house.gov/newsroom/press-releases/thompson-and-kellyintroduce-legislation-to-help-stop-abuse-of-conservation.
} 


\section{Filing a Tax Return Package to Minimize Risk of Audit}

- Correctly Drafted Conservation Easement Deed

- IRS Form 8283 \& Supplemental Statement

- Qualified Appraisal

- Contemporaneous Written Acknowledgment

- Correct and Timely Baseline Documentation

- Correct and Timely Lender Agreement (if applicable)

\section{A. Correctly Drafted Conservation Easement Deed}

1. File Copy of Recorded Conservation Easement Deed. A copy of the correctly drafted and recorded conservation easement deed should be either (i) filed with IRS Form 8283, Section B (the appraisal summary) or (ii) if the easement is valued at more than $\$ 500,000$, included in the qualified appraisal filed with IRS Form 8283.

a. Best practice is to either (i) file the date stamped copy of the recorded easement deed with the Form 8283 or (ii) have the appraiser include the date stamped copy of the recorded easement deed in the appraisal.

b. It is imperative that the appraiser values the easement as described in the final recorded easement deed rather than in an earlier draft.

c. As noted in the discussion of IRS Form 8283 in Part II.B below, the IRS has informally suggested that a copy of the qualified appraisal be included in the package filed with the federal income tax return on which a deduction for the easement donation is first claimed even if the appraised value of the easement is $\$ 500,000$ or less.

Façade easements on buildings in registered historic districts are subject to special rules. The taxpayer must include with the taxpayer's return for the year of the contribution, in addition to the Form 8283: (i) a qualified appraisal, (ii) photos of the entire exterior of the building, and (iii) a description of all restrictions on the development of the building. ${ }^{44} \mathrm{~A}$ date stamped copy of the recorded easement deed should be included with these items. If the deduction claimed is more than $\$ 10,000$, it will be allowed only if the taxpayer also includes a $\$ 500$ filing fee. ${ }^{45}$

2. Include Extensive Recitals. The conservation easement deed should include extensive recitals clearly indicating the conservation or historic values of the property that are worthy of protection.

3. "Exclusively for Conservation Purposes" Requirements. To be eligible for a deduction, the donation of a conservation easement must, among other things, be a contribution made "exclusively" for one of more of the four "conservation

\footnotetext{
${ }^{44}$ See IRC $\S 170(\mathrm{~h})(4)(\mathrm{B})(\mathrm{iii})$.

${ }^{45}$ See IRC § 170(f)(13); IRS Form 8283-V.
} 
purposes" enumerated in $\S 170(\mathrm{~h}) .{ }^{46}$ The contribution will not be treated as made exclusively for conservation purposes unless the conservation purpose is "protected in perpetuity." 47 Satisfying the "protected in perpetuity" requirement requires satisfying all of the following requirements: ${ }^{48}$

a. the eligible donee requirement, ${ }^{49}$

b. the restriction on transfer requirement, ${ }^{50}$

c. the no inconsistent uses requirement, ${ }^{51}$

d. the general enforceable in perpetuity requirement, ${ }^{52}$

e. the mortgage subordination requirement, ${ }^{53}$

f. the mineral extraction restrictions requirement, ${ }^{54}$

g. the baseline documentation, donee notice, donee access, and donee enforcement requirements, ${ }^{55}$ and

h. the extinguishment and proceeds requirements. ${ }^{56}$

Analysis by the IRS and the courts of the "exclusively for conservation purposes" requirement generally has not been systematic, making the cases somewhat difficult to categorize. Areas of focus have included whether the purpose is "protected in perpetuity" despite reserved rights or inconsistent uses, satisfaction of the conservation purposes test generally, whether the extinguishment and division of proceeds requirements were satisfied, and whether the mortgage subordination requirement was satisfied.

4. Extensive Reserved Rights. In Glass, Butler, and Pine Mountain II, the IRS argued unsuccessfully that, at full exercise of all reserved rights, the conservation purposes of the easements at issue would not be protected in perpetuity. For discussion of reserved development rights and the siting of building areas, see Part II.A.6, 7 , and 8 below.

\footnotetext{
${ }^{46}$ IRC $\S 170(\mathrm{~h})(1)(\mathrm{C}),(\mathrm{h})(4)$; Treas. Reg. $\S 1.170 \mathrm{~A}-14(\mathrm{a}),-14(\mathrm{~d})$. The four conservation purposes are protection of habitat, protection of open space, historic preservation, and preservation of land for outdoor recreation by or education of the general public.

${ }^{47}$ IRC $\S 170(\mathrm{~h})(1)(\mathrm{C}),(5)(\mathrm{A})$.

${ }^{48}$ See IRC $\S 170(\mathrm{~h})(5)(\mathrm{B})$ (addressing surface mining); Treas. Reg. § 1.170A-14(e)(1) ("To meet the requirements of this section, a donation must be exclusively for conservation purposes. See paragraphs (c)(1) and (g)(1) through (g)(6)(ii) of this section."). In addition, in explaining the "protected in perpetuity" requirement, the Senate Finance Committee provided instructions that were incorporated into the regulations as the restriction on transfer and no inconsistent use requirements of Treasury Regulation $\S \S 1.170 \mathrm{~A}-14(\mathrm{c})(2)$ and -14(e)(2). See S. Rep. No. 96-1007, 1980-2 C.B.

${ }^{49}$ Treas. Reg. $\S 1.170 \mathrm{~A}-14(\mathrm{c})(1)$.

${ }^{50}$ Treas. Reg. $\$ 1.170 \mathrm{~A}-14(\mathrm{c})(2)$.

${ }^{51}$ Treas. Reg. § 1.170A-14(e)(2), (3).

52 Treas. Reg. § 1.170A-14(g)(1).

${ }^{53}$ Treas. Reg. $\S 1.170 \mathrm{~A}-14(\mathrm{~g})(2)$ (applicable only if the property is subject to a mortgage at the time of the donation).

${ }^{54}$ IRC $\S 170(\mathrm{~h})(5)(\mathrm{B})$; Treas. Reg. § 1.170A-14(g)(4).

55 Treas. Reg. $\S 1.170 \mathrm{~A}-14(\mathrm{~g})(5)(\mathrm{i})$ and (ii). These requirements are applicable only if the "donor reserves rights the exercise of which may impair the conservation interests associated with the property." However, that will almost always be the case. Moreover, it is common practice and recommended that these requirements be satisfied with regard to every conservation easement donation because they help to ensure the holder will have the information as well as the notice, access, and enforcement rights needed to properly enforce the easement.

${ }^{56}$ Treas. Reg. § 1.170A-14(g)(6)(i) and (ii).
} 
a. Glass. In Glass, the Sixth Circuit affirmed the Tax Court's holding that two conservation easements protecting small portions of a ten-acre parcel located along the shoreline of Lake Michigan satisfied the "exclusively" for habitat protection "conservation purposes" requirement. The IRS argued, among other things, that the easements failed to satisfy this requirement because (i) the protected properties were too small, (ii) the taxpayers reserved too many rights in the easements, and (iii) there were no limits on building on neighboring properties. The Sixth Circuit rejected those arguments, finding that (i) neither $\S 170(\mathrm{~h})$ nor the Treasury Regulations require that the subject property be a minimum size, ${ }^{57}$ (ii) although the easements reserved various use rights to the taxpayers, both also contained an overarching restriction prohibiting "[a]ny activity on or use of the Property that is inconsistent with the purpose of this Conservation Easement," and provided that the easement "shall be liberally construed in favor of the purpose of [the easement, the land trust holder, and the state conservation easement enabling statute]," and (iii) neither $\S 170(\mathrm{~h})$ nor the Treasury Regulations require consideration of neighboring property owners' building rights when assessing the deductibility of a conservation easement. The taxpayers in Glass also provided credible testimony at trial indicating that exercise of the reserved rights would not be inconsistent with the habitat protection purpose of the easements, while the IRS failed to provide any evidence to the contrary. For more on Glass, see Part II.A.5 below.

b. Butler. In Butler, the IRS asserted that the rights retained by the landowners in the conservation easement deeds meant that the habitat and open space protection conservation purposes of the easements were not "protected in perpetuity." The Tax Court disagreed, finding that the habitat protection conservation purpose test would still be satisfied even if the properties were developed to the fullest extent permitted by the easement deeds. ${ }^{58}$ However, the holding in Butler should not be viewed as a green light for retaining extensive development and use rights in a conservation easement deed for a number of reasons.

(i) The burden of proof regarding satisfaction of the conservation purposes test, which normally falls on the taxpayer, had shifted to the IRS.

(ii) The parties disagreed about whether the conservation easement deeds restricted the location of the building sites. The donors argued that the deeds incorporated the baseline documentation by reference, and the baseline included a map stipulating the placement of the

\footnotetext{
${ }^{57}$ For a critique of the Sixth Circuit's holding on this point, see Jonathan M. Burke, A Critical Analysis of Glass $v$. Commissioner: Why Size Should Matter for Conservation Easements, 61 TAX LAWYER 599 (2008).

${ }^{58}$ Because the court found that the easements satisfied the habitat protection conservation purposes test it did not address the open space conservation purposes test.
} 
building sites in locations consistent with the preservation of the conservation purposes. The court found that, under Georgia law, reference in the recorded deeds to the baseline effectively made the baseline (including the map) part of the recorded deeds, and the restrictions on the location of the lots in the map were therefore binding.

(iii) The donors offered some (albeit "sparse") evidence in the form of testimony of environmental consultants to support their contention that the reserved rights were not inconsistent with the conservation purposes of the easements and, as in Glass, the IRS failed to introduce any evidence to the contrary.

c. Additional Case Law. After Butler was decided, the IRS informally indicated that in future cases it intended to hire its own environmental experts to testify as to whether the conservation purpose of an easement would be protected in perpetuity upon full exercise of all reserved rights. As discussed in Part II.A.5 below, the IRS hired its own environmental experts in Atkinson, PBBM-Rose Hill, and Champions Retreat and was able to establish that the easements at issue did not satisfy habitat protection conservation purpose test due, in part, to the reserved rights in the deeds. ${ }^{59}$ However, in Pine Mountain II, as discussed in Part II.A.6 below, the IRS again lost the argument that extensive reserved rights in an easement permitted the subject property to be used in ways inconsistent with the conservation purposes of the donation because the taxpayer provided expert testimony (in the form of the land trust's biologist) that this was not the case, and the IRS failed to provide any evidence to the contrary.

d. Overarching Restriction. To prevent uses inconsistent with the conservation purposes of the donation, a conservation easement should (1) specifically reserve to the grantor (and the grantor's successors) only those rights that, even if fully exercised, would be consistent with the conservation purpose of the easement, (2) specifically prohibit activities that are inconsistent with the conservation purpose of the easement (such as subdivision, mining, and industrial uses), and (3) because it is impossible at the time of conveyance to specify in the deed every conceivable variation of use, activity, or practice that in the future might have an adverse impact on the conservation purpose of the easement, include an overarching restriction prohibiting any activities that are inconsistent with the conservation purpose of the easement or the perpetual protection of the property's conservation values. The overarching restriction is necessary to prevent the present or a future landowner from claiming that she has the right to do anything not specifically prohibited by the easement even if it

\footnotetext{
${ }^{59}$ See also IRS Conservation Easement Audit Techniques Guide, supra note 23, at 18 ("The Tax Court's reliance on the Service's expert reports and testimony in Atkinson demonstrates the importance of expert evidence in these types of 'protecting natural habitat' cases.").
} 
would be inconsistent with the purpose of the easement or continued protection of the property's conservation values. ${ }^{60}$

e. Liberal Construction Provision. A conservation easement should also include a provision stating that the parties to the easement (and their successors) affirmatively agree and intend that, notwithstanding any general rule of construction to the contrary, the easement shall be liberally construed in favor of permanently protecting the property's conservation values and carrying out the conservation purposes of the easement. ${ }^{61}$ In the absence of such a provision, there is a danger that ambiguous terms in the easement will be construed in favor of free use of land and that the conservation purposes of the easement will not be deemed "protected in perpetuity" as required by $\S 170(\mathrm{~h}){ }^{62}$

Some state conservation easement enabling statutes mandate that conservation easements be liberally construed in favor of effecting their conservation purposes. ${ }^{63}$ However, given that statutes are subject to change at any time, every conservation easement deed should nonetheless include a liberal construction provision.

5. Conservation Purposes Test. Satisfaction of the conservation purposes test was an issue in Turner, Glass, RP Golf I, Atkinson, PBBM-Rose Hill I and II, Champions Retreat, Carroll, Herman I, Partita Partners $I^{64}$

a. Turner. In Turner, the Tax Court sustained the IRS's disallowance of deductions claimed with respect to the donation of a conservation easement because the donation did not satisfy either the open space or historic

${ }^{60}$ See Glass; Priv. Ltr. Rul. 200836014

${ }^{61}$ See, e.g., Byers \& Ponte, The Conservation Easement Handbook 376, 466-67 (2d ed. 2005).

${ }^{62}$ See Wetlands America Trust v. White Cloud Nine Ventures, 782 S.E.2d 131 (Va. 2016), in which the court held that the common law rule of construction requiring land use restrictions to be interpreted in favor of free use of land applied to the conservation easement at issue and the enabling statutes in Virginia do not abrogate that rule of construction. There was a strong dissent:

Contrary to the majority's conclusion, the common law principle of strict construction in favor of free use of land no longer applies to conservation easements. The strict construction principle was applied under the common law because easements in gross, including negative easements in gross, were disfavored as a matter of public policy. Today, and for at least the last four decades, Virginia public policy strongly favors the conservation of land and open spaces.... The oft-stated policy of the Commonwealth in favor of conservation easements such as the type at issue here could not be a clearer rejection of the common law strict construction principle.

See id. See also Nancy A. McLaughlin, Interpreting Conservation Easements, 29 PROB. \& Prop. 30 (2015) (explaining why conservation easements should be interpreted in favor of carrying out their public-benefiting conservation purposes rather than in favor of free use of land), available at http://bit.ly/1KSyi2U.

${ }^{63}$ See 32 Pa. CONS. STAT. $§ 5055$ (c)(2) ("Any general rule of construction to the contrary notwithstanding, conservation or preservation easements shall be liberally construed in favor of the grants contained therein to effect the purposes of those easements and the policy and purpose of this act"); W. VA. CODE § 20-12-5(b) ("Notwithstanding provision of law to the contrary, conservation and preservation easements shall be liberally construed in favor of the grants contained therein to effect the purposes of those easements and the policy and purpose of this article").

${ }^{64}$ See also Patel v. Comm'r, 138 T.C. 395 (2012) (while contribution of a taxpayer's house to a volunteer fire department for destruction by burning during training exercises serves to further the protection of property by providing valuable training experience for volunteer firefighters, it does not satisfy the conservation purpose test of $\S 170(\mathrm{~h})$ ). 
preservation conservation purposes tests. Turner involved a purported donation to Fairfax County, Virginia, of a conservation easement encumbering a 29.3-acre parcel located in a historic overlay district. ${ }^{65}$ The subject property is in the general vicinity of Mount Vernon, President George Washington's 500-acre residential estate; adjacent to President Washington's Grist Mill; and in close proximity to the Woodlawn Plantation, which was built in 1805 on land owned by President Washington. In obtaining an appraisal of the easement, the donor (an attorney whose practice concentrated on real estate transactions) represented that 60 residences could be built on the 29.3-acre parcel and that the easement reduced the number of permitted residences to 30 . In reality, however, zoning regulations already limited development to 30 residences because slightly more than half of the parcel (15.04 acres) was situated within a designated 100-year floodplain. ${ }^{66}$

The Tax Court held that the easement did not satisfy the open space conservation purpose test because it did not limit the size of the residences that could be built on the 15 acres (either in square footage or height) and did not contain any provisions to protect the views from the nearby historic sites. The easement also did not satisfy the historic preservation conservation purpose test because it did not preserve a historic structure or historically important land area. The court explained:

Here there has been no preservation of open space. Nor [has the donor] preserved anything that is historically unique about the property or the surrounding historical areas. [The donor] simply developed the property to its maximum yield within the property's zoning classification. ${ }^{67}$

b. Glass. In Glass, the Sixth Circuit affirmed the Tax Court's holding that two conservation easements protecting small portions of a ten-acre parcel located along the shoreline of Lake Michigan satisfied the habitat protection conservation purposes test. The IRS argued that the easements failed to satisfy this test because, among other things, threatened species had not actually been sighted living on the properties. The Sixth Circuit rejected that argument, finding that (i) the habitat protection conservation purposes test can be satisfied if the easement protects property that is potential habitat for rare, threatened, or endangered species, and (ii) one of the taxpayers and the executive director of the donee land trust credibly testified that the property

\footnotetext{
65 The donation is referred to as "purported" because Fairfax County did not sign or acknowledge the conservation easement deed or sign the Form 8283.

${ }^{66}$ Although the donor could have attempted to obtain approval to rezone the parcel, the court noted that obtaining such approval would have been time-consuming and costly, and success was not guaranteed.

${ }^{67}$ See also Joe Stephens, IRS Gets 'First Big Win' in Push to Stem Abuse of Conservation Tool, Wash. Post A01 (June 4,2006 ) (describing the transaction as a $\$ 3.1$ million donation that promised not to overdevelop scenic land once owned by George Washington and located down the road from Mount Vernon, but developers clear-cut acres of trees on the property and erected 29 sprawling homes that preservationists today deride as 'McMansions.'”).
} 
was a "famous roosting spot" for bald eagles and that there were threatened plant species on the properties. As explained in Part II.A.4 above, the Sixth Circuit also rejected the IRS's arguments that the easements failed to satisfy the habitat protection conservation purposes text because (i) the protected properties were too small, (ii) the taxpayers reserved too many rights in the easements, and (iii) there were no limits on building on neighboring properties.

c. $R P$ Golf I. In RP Golf I, the IRS asserted that the conservation easement donation at issue was not made "exclusively for conservation purposes," in part because the Missouri conservation policy the taxpayer referenced in the easement deed was limited to certain areas of the state and there was no evidence that the subject property was located in such an area on the date of the donation. The taxpayer was forced to concede that the easement was not made pursuant to a "clearly delineated governmental conservation policy." 68

d. Atkinson. In Atkinson, the Tax Court sustained the IRS's disallowance of $\$ 7.88$ million of deductions claimed with regard to the conveyance of conservation easements encumbering land on and adjacent to golf courses located in a gated and guarded residential community in North Carolina. The court determined that the easements, which were conveyed to the North American Land Trust, did not satisfy either the habitat or open space protection conservation purposes tests. The properties subject to the easements consisted of noncontiguous tracts (i.e., fairways, greens, teeing grounds, ranges, roughs, ponds, and wetland areas); residential lots bordered most of the tracts; and a concrete golf cart path winded its way through the tracts. The taxpayers argued that each of the subject properties had independent conservation significance and contributed to the ecological viability of surrounding conservation areas. The IRS focused on the operation of the golf courses and argued that the rights retained in the easements negated any purported conservation purpose.

Unlike in Glass and Butler, in Atkinson both the taxpayers and the IRS presented expert environmental testimony to establish their respective positions regarding the habitat protection conservation purposes test. In holding that the conservation easements did not satisfy this test, the Tax Court noted, among other things, that the most significant ecological features on the subject properties - the longleaf pine "remnants"-were not maintained in a relatively natural state worthy of conservation and were not protected in any event because the easements permitted cutting and removal of the trees; very few of the ponds had a natural edge and the few edges that

\footnotetext{
${ }^{68}$ The court found that material facts regarding the easement's preservation of a natural habitat continued to be in dispute. The court ultimately did not rule on that issue because it sustained the IRS's disallowance of the deduction on the ground that the taxpayer failed to obtain mortgage subordination agreements at the time of the easement's donation. See Part II.F.2 below.
} 
existed were regularly sprayed with pesticides; there were no natural fruits and seeds for foraging on the properties; the properties provided no cover for animals; and animal migration was deterred by the residential development surrounding each of the noncontiguous tracts, the level of human activity, and the frequent watering. In addition, the only birds the IRS's environmental expert observed on one of the properties were geese, which the community attempted to "control" (i.e., drive away) using a border collie. The court also found that the use of pesticides and other chemicals in the operation of the golf course injured the ecosystems on the subject properties and, thus, violated the "no inconsistent use" requirement of Treasury Regulation $\S 1.170 \mathrm{~A}-14(\mathrm{e})(2)$. The court concluded that wildlife and plants were not "most likely" to be found and did not "normally live" on the properties subject to the easements, but declined to decide whether operating a golf course is inherently inconsistent with the conservation purpose of protecting relatively natural habitat.

With regard to the open space conservation purposes test, the Tax Court noted that the taxpayers did not mention or provide any analysis of governmental conservation policies in their briefs, and the court deemed that argument abandoned. The taxpayers also failed to establish that preservation of the subject properties was for the scenic enjoyment of the general public. Since the golf courses were in a gated and guarded community and ringed by houses, the court found that the general public did not have visual access to the properties. The taxpayers argued that the general public had visual access because most of the population of the Town of St. James lived within the gated community. The court, however, did not deem the population of one town to constitute "the general public." 69

e. PBBM-Rose Hill. In PBBM-Rose Hill I, the Tax Court, in a Bench Opinion, sustained the IRS's disallowance of a $\$ 15.16$ million deduction claimed by the PBBM-Rose Hill partnership for the conveyance of a conservation easement encumbering a 27-hole golf course interspersed among houses in a gated and guarded residential community in South Carolina. Among other things, the court determined that the easement, which was conveyed to the North American Land Trust, did not satisfy the habitat protection, open space protection, or outdoor recreation for the general public conservation purposes tests.

Unlike in Glass and Butler, both the taxpayer and the IRS presented expert environmental testimony to establish their respective positions regarding the habitat protection conservation purposes test. In determining that the easement failed that test, the Tax Court explained that the IRS's expert testified credibly that, among other things, most of the encumbered property consisted of the golf course, which was dominated by non-native grasses,

${ }^{69}$ For media coverage, see Richard Rubin, IRS Tees Off on GolfCourses' Green Tax Claims, WaLl St. J. (Jan. 14, 2016). Atkinson is on appeal in the Fourth Circuit. 
required continued application of fungicides and pesticides, and was not conducive to wildlife; the quality of the ponds on the property was similar to that of waterways in urban areas; and many of the trees on the property were in isolated patches or thin strips.

In finding that the easement failed the open space conservation purposes test, the Tax Court explained that the easement (i) did not preserve the property for the scenic enjoyment of the general public because it mainly benefited the homeowners in the gated and guarded residential community and (ii) did not preserve the property pursuant to a clearly delineated governmental conservation policy because the relevant policies addressed ecological preservation and the IRS's expert testified that the ecological value of the easement was low.

In finding that the easement failed to preserve the property for the outdoor recreation of the general public, the Tax Court noted that (i) there were conflicting provisions in the easement regarding public access and (ii) the owner of the property (the homeowners association) had converted a significant portion of the property into a private park.

The case was appealed, and in PBBM-Rose Hill II, while affirming the denial of the deduction, ${ }^{70}$ the Fifth Circuit held that the easement satisfied the outdoor recreation for the general public conservation purposes test ${ }^{71}$ because (i) the provision in the easement requiring that the property remain open for substantial and regular outdoor-recreation use by the general public was deemed to be "specific" and thus given greater weight than the conflicting provision that stated that nothing in the deed shall be construed to create any right of public access to the property, which was deemed to be "general," and (ii) in determining whether the public-access requirement is satisfied, the focus should generally be on the terms of the deed and not on the actual use of the land after the easement's donation. As the Fifth Circuit noted, however: "The public does not have access to the park; a sign on the road to the park states '[p]roperty owners, residents \& guests only beyond this point."' Accordingly, the IRS and the South Carolina Attorney General could seek to sanction the North American Land Trust for failing to enforce the "specific" public access provision of the easement given that such failure benefits the homeowners in the gated and guarded community (i.e., provides a private benefit). It also would be helpful for the IRS to provide guidance regarding what is meant by "substantial and regular use by the general public" to help ensure that only easements that actually provide a significant benefits to the general public are subsidized through the $\S 170(\mathrm{~h})$ deduction.

\footnotetext{
${ }^{70}$ As discussed in Part II.A.12, the Fifth Circuit determined that the clause included in the easement deed providing for the payment of a share of the proceeds to the holder following extinguishment did not comply with the proceeds requirement in Treasury Regulation $\S 1.170 \mathrm{~A}-14(\mathrm{~g})(6)(\mathrm{ii})$ and, thus, the partnership was not entitled to a deduction. The Fifth Circuit also agreed with the Tax Court that the easement had a value of only $\$ 100,000$.

${ }^{71}$ This was the only conservation purposes test at issue on appeal.
} 
f. Champions Retreat. In Champions Retreat, the Tax Court sustained the IRS's disallowance of a $\$ 10.427$ million deduction claimed by the Champions Retreat LLC for the conveyance of a conservation easement encumbering most of a 27-hole golf course interspersed among houses in a gated and guarded residential community in Evans, Georgia. The court determined that the easement, which was conveyed to the North American Land Trust, did not satisfy the habitat or open space protection conservation purposes tests.

Unlike in Glass and Butler, both the taxpayer and the IRS presented expert environmental testimony to establish their respective positions regarding the habitat protection conservation purposes test. In determining that the easement failed that test, the Tax Court noted, among other things, that: (i) the golf course property had very little plant species diversity and the wetland, forested, and open pond areas that had survived the golf course development accounted for only a little over $16 \%$ of the property, (ii) environmentally hazardous fungicides, herbicides, and insecticides were applied to the property, the staff members applying these chemicals were required to wear protective gear including gloves and respirators, and some of the holes were specifically designed to drain into the creeks, ponds, and remaining wetland and forested areas on the property, (iii) the streams on the property exhibited little variety of aquatic life and one emitted a sulfurous odor and had an oily sheen, and (iv) while the LLC argued that the property provided a habitat for several species of conservation concern, including the southern fox squirrel and the denseflower knotweed, the squirrel was still legally hunted in Georgia (hunters could kill up to 12 per day during the six-month hunting season), and the bottomland forest areas that could provide habitat for the denseflower knotweed constituted less than $17 \%$ of the property and were used as drainage for the holes, thus subjecting those areas to the chemicals used on the course.

In finding that the easement failed the open space conservation purposes test, the Tax Court explained that the easement did not preserve the property for the scenic enjoyment of the general public because the property was physically accessible only to members and their guests through a gate manned 24 hours a day, visual access to the property was very limited, and the annual charity events held at the golf club did not provide sufficient physical access to public. In addition, the court determined that the easement did not preserve the property pursuant to a clearly delineated governmental conservation policy because the policies cited by the LLC did not satisfy the Treasury Regulation requirements and one of the policies was focused on development rather than conservation.

g. Carroll. In Carroll, the Tax Court sustained the IRS's disallowance of deductions claimed with regard to the donation of a conservation because 
the easement contained a noncompliant "proceeds" clause. ${ }^{72}$ However, the court also held that the easement satisfied the open space conservation purpose test under $\S 170(\mathrm{~h})(4)(\mathrm{A})(\mathrm{iii})(\mathrm{II})$, which requires that preservation of the property be "pursuant to a clearly delineated Federal, State, or local governmental conservation policy" and "yield a significant public benefit." The easement, which encumbers a 21-acre property located in a historic district in Maryland, was granted to the Maryland Environmental Trust (MET) and the Land Preservation Trust (LPT), as joint holders. MET is a quasi-public entity that the Maryland legislature established in 1967 to conserve the environment; it is both a unit of the Maryland Department of Natural Resources and governed by a board of trustees. LPT is a charitable conservation organization.

In interpreting the governmental conservation policy requirement, Treasury Regulation $\S 1.170 \mathrm{~A}-14(\mathrm{~d})(4)(\mathrm{iii})(\mathrm{B})$ provides that:

Acceptance of an easement by an agency of the Federal Government or by an agency of a state or local government (or by a commission, authority, or similar body duly constituted by the state or local government and acting on behalf of the state or local government) tends to establish the requisite clearly delineated governmental policy, although such acceptance, without more, is not sufficient. The more rigorous the review process by the governmental agency, the more the acceptance of the easement tends to establish the requisite clearly delineated governmental policy. For example, in a state where the legislature has established an Environmental Trust to accept gifts to the state which meet certain conservation purposes and to submit the gifts to a review that requires the approval of the state's highest officials, acceptance of a gift by the Trust tends to establish the requisite clearly delineated governmental policy. However, if the Trust merely accepts such gifts without a review process, the requisite clearly delineated governmental policy is not established.

In finding that the easement in Carroll satisfied the open space conservation purpose test, the Tax Court explained that the thoroughness of MET's easement-review process, combined with the fact that Maryland's highest officials (the Governor, the Comptroller, and the Treasurer of Maryland) approved the easement, established that the easement preserves open space pursuant to a clearly delineated governmental conservation policy. The Tax Court also determined that preservation of the 21 -acre property yielded a significant public benefit because (i) the property was in a highly desirable area under development pressure, (ii) the property was subject to a restrictive type of zoning established to foster and protect agricultural lands in certain areas, (iii) the valley in which the property was located was

\footnotetext{
${ }^{72}$ See Part II.A. 12 below.
} 
specifically designated in the county's Master Plan as an agricultural preservation area, and (iv) four properties adjacent to the property were encumbered by conservation easements held by MET or a state agency.

h. Herman I. In Herman I the Tax Court sustained the IRS's disallowance of a \$21.8 million deduction for the conveyance in 2003 of a facade easement to the National Architectural Trust. The easement encumbered 10,000 unspecified square feet of the approximately 22,000 square feet of unused development rights (UDRs) above a certified historic structure (or 45 percent of the UDRs). ${ }^{73}$ The easement did not, however, prevent alteration or demolition of the structure or prohibit the building of six stories over any half (front, back, or side) of the structure. Accordingly, the court found that the easement did not protect either the structure or the historic significance of the underlying land and, thus, did not satisfy the historic preservation conservation purposes test. In 2006, $\S 170(\mathrm{~h})$ was amended to expressly require that, to be deductible, a façade easement with respect to a building in a registered historic district must preserve the entire exterior of the building (including the front, sides, rear, and height of the building). ${ }^{74}$

i. Partita Partners I. In Partita Partners I, the U.S. District Court for the Southern District of New York sustained the IRS's disallowance of a $\$ 4.186$ million deduction for the conveyance in 2008 of a façade easement to the Trust for Architectural Easements (formerly the National Architectural Trust). The easement did not preserve the entire exterior of the building as required by $\S 170(\mathrm{~h})$. Partita Partners LLC argued that, because any construction would require the approval of the Trust for Architectural Easements, alteration of the exterior of the building was unlikely. The court rejected that argument, explaining that $\S 170(\mathrm{~h})$ requires a restriction that preserves the entire exterior of the building, not a conditional restriction that delegates to the grantee future decisions regarding development of the exterior.

\section{Extinguishments (Including Swaps) Require a Judicial Proceeding;} Building Areas; Amendment Clauses. The conservation easement deed should include provisions satisfying the restriction on transfer and extinguishment requirements of Treasury Regulation $\S \S 1.170 \mathrm{~A}-14(\mathrm{c})(2)$ and $-14(\mathrm{~g})(6)$, which are related. ${ }^{75}$ Sample "Restriction on Transfer" and "Extinguishment" Provisions are included in Part II.A.11 below.

a. Carpenter I. In Carpenter I, the Tax Court held that conservation easements extinguishable by mutual agreement of the parties, even if

\footnotetext{
73 The certified historic structure was an eleven-story apartment building located on Fifth Avenue in New York City that had been designed by the late Henry Otis Chapman in 1923 in the neo-Italianate Renaissance style of architecture.

${ }^{74}$ See IRC $\S 170(\mathrm{~h})(4)(B)(\mathrm{i})$. See also JCT Explanation of Pension Protection Act of 2006, supra note 17, at 294-95.

${ }^{75}$ See Treas. Reg. $\S 1.170 \mathrm{~A}-14$ (c)(2). In the last sentence of this regulation, the cross-reference to (b)(3) should be to (b)(2), and the cross-reference to (g)(5)(ii) should be to $(\mathrm{g})(6)$; the Treasury failed to update the cross-references when it finalized the proposed regulations in 1986.
} 
subject to a standard such as "impossibility," fail as a matter of law to satisfy the judicial extinguishment requirements in Treasury Regulation $\S 1.170 \mathrm{~A}-$ 14(g)(6)(i).

(i) In support of its holding, the Tax Court explained:

Extinguishment by mutual consent of the parties does not guarantee that the conservation purpose of the donated property will continue to be protected in perpetuity. As at least one commentator has noted, the "restrictions [in a deed] are supposed to be perpetual in the first place, and the decision to terminate them should not be [made] solely by interested parties. With the decision-making process pushed into a court of law, the legal tension created by such judicial review will generally tend to create a fair result." Small, Federal Tax Law of Conservation Easements 16-4 (1986).

The court referenced this passage again in reaffirming and supplementing its opinion in Carpenter II.

(ii) With regard to federal and state law interaction, the court in Carpenter I explained:

To determine whether the conservation easement deeds comply with requirements for the...deduction under Federal tax law, we must look to State law to determine the effect of the deeds. State law determines the nature of the property rights, and Federal law determines the appropriate tax treatment of those rights. ${ }^{76}$

(iii) The court in Carpenter I also held that the "so-remote-as-to-benegligible" standard of Treasury Regulation $\S 1.170 \mathrm{~A}-14(\mathrm{~g})(3)$ does not modify the extinguishment requirements of Treasury Regulation $\S 1.170 \mathrm{~A}-14(\mathrm{~g})(6)(\mathrm{i})$. Accordingly, failure to comply with the extinguishment requirements cannot be cured by a showing that the possibility of extinguishment is so remote as to be negligible.

b. Carpenter II. In Carpenter II, the Tax Court confirmed that "extinguishment by judicial proceedings is mandatory." 77 The court

\footnotetext{
${ }^{76}$ See also Patel v. Comm'r, 138 T.C. 395 (2012) (State law determines only which sticks are in a person's bundle. . . . Once property rights are determined under State law, as announced by the highest court of the State, the tax consequences are decided under Federal law).

77 See also IRS General Information Letter on extinguishment, supra note 26 and accompanying text. The Land Trust Alliance's 2007 amendment report instructs:

If the conservation easement was the subject of a federal income tax deduction, then Internal Revenue Code Section 170(h) and the Treasury Regulations Section 1.170A-14 apply.... The easement must be transferable only to another government entity or qualified charitable organization that agrees to continue to enforce the easement. The easement can only be extinguished by the holder through a judicial proceeding, upon a finding
} 
specifically rejected the taxpayers' arguments that the Treasury Regulations contemplate alternatives to judicial extinguishment and that the judicial proceeding requirement is "merely a safe harbor."

The court also rejected the taxpayers' argument that the First Circuit's decision in Kaufman III was an intervening change in the law that required the court to reconsider its holding in Carpenter I. The court explained that, not only is Kaufman III not binding in the Tenth Circuit (to which Carpenter would have been appealed), Kaufman III addressed legal issues different from those present in Carpenter. ${ }^{78}$ The court also noted that it does not read Kaufman III as sanctioning "putting into the hands of the parties to a conservation agreement the authority to determine when to extinguish the conservation easement so long as the donee organization gets its shares of the proceeds of a subsequent sale."

c. Mitchell II. In Mitchell II, the Tax Court similarly rejected the argument that Kaufman III was an intervening change in the law requiring it to reconsider its holding in Mitchell $I .{ }^{79}$ The court explained that, not only is Kaufman III not binding in the Tenth Circuit (to which Mitchell was appealed and affirmed), Kaufman III addressed legal issues different from those present in Mitchell. ${ }^{80}$ The court reiterated that Treasury Regulation $1.170 \mathrm{~A}-14(\mathrm{~g})(6)$ is not "merely...a safe harbor," and the specific provisions of Treasury Regulation $\S 1.170 \mathrm{~A}-14(\mathrm{~g})(1)$ through $(\mathrm{g})(6)$ "are mandatory and may not be ignored." The court further rejected the taxpayer's argument that the court should "draw a general rule" with respect to the in-perpetuity requirement of $\S 170(\mathrm{~h})(5)(\mathrm{A})$ and Treasury Regulation $\S 1.170 \mathrm{~A}-14(\mathrm{~g})$ from the analysis in Kaufman III. The taxpayer had asserted: "The regulation emphasizes perpetuating an easement's purpose as opposed to the conservation easement itself. The proceeds are protected which is the goal of the law." The Tax Court disagreed, stating: "Nowhere in Kaufman III did the Court of Appeals for the First Circuit state a general rule that protecting the proceeds from an extinguishment of a conservation easement would satisfy the in-perpetuity requirements of section $\S 1.170 \mathrm{~A}-14(\mathrm{~g})$... generally." In other words, the court held that $\S 170(\mathrm{~h})$ requires perpetuation of the conservation easement itself, not conservation purposes generally.

that continued use of the encumbered land for conservation purposes has become "impossible or impractical," and with the payment to the holder of a share of proceeds from a subsequent sale or development of the land to be used for similar conservation purposes. To the extent an amendment amounts to an extinguishment, the land trust must satisfy these requirements.

Land Tr. Alliance, Amending Conservation Easements: Evolving Practices and Legal Principles 24 (2007).

${ }^{78}$ Kaufman III involved interpretation of Treasury Regulation $\S 1.170 \mathrm{~A}-14(\mathrm{~g})(1)$ (the "general enforceable in perpetuity" requirement) and Treasury Regulation $\S 1.170 \mathrm{~A}-14(\mathrm{~g})(6)(\mathrm{ii})$ (the "proceeds" requirement). Carpenter, on the other hand, involved interpretation of Treasury Regulation $\S 1.170 \mathrm{~A}-14(\mathrm{~g})(6)(\mathrm{i})$ (the "extinguishment" requirement)).

${ }^{79}$ In Mitchell I the Tax Court sustained the IRS's disallowance of a deduction for an easement donation because the taxpayer failed to obtain a mortgage subordination agreement at the time of the gift. See Part II.F.2.

80 Mitchell involved interpretation of Treasury Regulation $\S 1.170 \mathrm{~A}-14(\mathrm{~g})(2)$ (the "mortgage subordination" requirement). 
Mitchell was appealed to the Tenth Circuit, which affirmed the Tax Court (see Part II.F.2 below).

d. Belk. In Belk III, the Fourth Circuit affirmed the Tax Court in holding that a conservation easement that authorizes the parties to agree to "substitutions" or "swaps" (i.e., to remove some or all of the original protected land from the easement, or unencumber that land, in exchange for the protection of similar contiguous land upon the approval of the donee land trust) is not eligible for a deduction. The Fourth Circuit explained that such an easement is not "a restriction (granted in perpetuity) on the use which may be made of the real property" as required under $\S 170(\mathrm{~h})(2)(\mathrm{C})$. The Fourth Circuit agreed with the Tax Court that, to be eligible for a deduction under $\S 170(\mathrm{~h})$, a donor must grant an easement with regard to a "single, immutable" or "defined and static" parcel.

(i) The Easement. The easement at issue in Belk encumbers a 184acre semi-private golf course located in a high-end residential development near Charlotte, North Carolina. The Belks donated the easement to the Smoky Mountain National Land Trust and claimed a $\$ 10.5$ million deduction. ${ }^{81}$ The easement deed authorizes the landowner to remove land from the easement in exchange for adding an equal or greater amount of contiguous land, provided that, in the opinion of the grantee:

- the substitute property is of the same or better ecological stability,

- the substitution will have no adverse effect on the conservation purposes of the easement, and

- the fair market value of the "easement interest" placed on the substitute land will be at least equal to or greater than the fair market value of the "easement interest" extinguished with regard to the land removed from the easement.

(ii) Single Narrow Exception to Perpetuity. In affirming the Tax Court's holding that the Belks were not eligible for a deduction, the Fourth Circuit explained that the "Treasury Regulations offer a single - and exceedingly narrow - exception to the requirement that a conservation easement impose a perpetual use restriction":

[if a] subsequent unexpected change in the conditions surrounding the property...make[s] impossible or impractical the continued use of the property for conservation purposes, the conservation purpose can nonetheless be treated as protected in perpetuity if the restrictions are extinguished by judicial proceeding and all of the donee's proceeds...from a subsequent sale or exchange of the property are used by the donee

\footnotetext{
${ }^{81}$ The Smoky Mountain National Land Trust has since changed its name to Southwest Regional Land Conservancy.
} 
organization in a manner consistent with the conservation purposes of the original contribution. Treas. Reg. $\S 1.170 \mathrm{~A}-$ 14(g)(6)(i) (emphasis added by the court).

"[A]bsent these 'unexpected' and extraordinary circumstances," explained the Fourth Circuit, "real property placed under easement must remain there in perpetuity in order for the donor of the easement to claim a charitable deduction."

(iii) Critical Requirements. The Fourth Circuit explained that permitting a deduction for the donation of the Belk easement would enable taxpayers to bypass several requirements critical to the statutory and regulatory schemes governing deductions for charitable contributions.

- For example, permitting the Belks to change the boundaries of the easement would render "meaningless" the requirement that an easement donor obtain a qualified appraisal because the appraisal would no longer be an accurate reflection of the value of the easement, parts of which could be clawed back. "It matters not," said the court, "that the Easement requires that the removed property be replaced with property of 'equal or greater value,' because the purpose of the appraisal requirement is to enable the Commissioner, not the donee or donor, to verify the value of a donation. The Easement's substitution provision places the Belks beyond the reach of the Commissioner in this regard."

- Similarly, the baseline documentation requirement "would also be skirted if the borders of an easement could shift." "Not only does this regulation confirm that a conservation easement must govern a defined and static parcel," explained the court, "it also makes clear that holding otherwise would deprive donees of the ability to ensure protection of conservation interests by, for instance, examination of maps and photographs of "the protected property."'

(iv) Kaufman and Simmons Distinguishable. The Belks argued that Kaufman III and Simmons II support the notion that $\S 170(\mathrm{~h})$ does not require that easement restrictions attach to a single, defined parcel. The Fourth Circuit rejected that argument, explaining that those "out-of-circuit" cases:

plausibly stand only for the proposition that a donation will not be rendered ineligible simply because the donee reserves its right not to enforce the easement. They do not support the Belks' view that the grant of a conservation easement qualifies for a 
charitable deduction even if the easement may be relocated. Indeed, as we have explained, such a holding would violate the plain meaning of $\S 170(\mathrm{~h})(2)(\mathrm{C}){ }^{82}$

(v) Federal Law Controls. The Belks argued that, because North Carolina law permits parties to amend or swap easements, like a right-of-way easement between neighbors, not permitting swaps would render all conservation easements in North Carolina ineligible for a deduction under $\S 170(\mathrm{~h})$. The Fourth Circuit found this argument "unpersuasive," explaining:

whether state property and contract law permits a substitution in an easement is irrelevant to the question of whether federal tax law permits a charitable deduction for the donation of such an easement...§ $170(\mathrm{~h})(2)(\mathrm{C})$ requires that the gift of a conservation easement on a specific parcel of land be granted in perpetuity to qualify for a federal charitable deduction, notwithstanding the fact that state law may permit an easement to govern for some shorter period of time. Thus, an easement that, like the one at hand, grants a restriction for less than a perpetual term, may be a valid conveyance under state law, but is still ineligible for a charitable deduction under federal law.

With the exception of North Dakota, which limits the duration of any easement created in the State to 99 years, it appears that the parties to a conservation easement can include provisions in the deed to comply with the federal tax law perpetuity requirements and, provided the easement is drafted appropriately, those provisions will be legally binding on both the landowner and the holder even though they impose conditions on the transfer or extinguishment of the easement that may be different or more restrictive than those imposed by state law (see Parts II.A. 9, 10, and 11 below, discussing the interaction between state and federal law).

(vi) Savings Clause Did Not Save Deduction. The substitution provision in the Belk conservation easement provided that substitutions become final when they are reflected in a formal recorded "amendment." The amendment provision in the easement provided that the land trust could not agree to any amendment that would result in the easement failing to qualify as a qualified

\footnotetext{
${ }^{82}$ In Simmons II, the D.C. Circuit implicitly rejected the argument of the amici curiae (the National Trust for Historic Preservation et al.) that land trusts should be permitted to agree with developers to extinguish perpetual easements on some properties to allow development of those properties in exchange for the receipt of easements on other properties. The D.C. Circuit held, in part, that an "eligible donee" must have a "commitment to protect the conservation purposes of the donation" and "the resources to enforce the restrictions" and that a tax-exempt organization would fail to enforce a conservation easement "at its peril." The D.C. Circuit also concluded that the donated easements at issue in Simmons II "will prevent in perpetuity any changes to the properties inconsistent with conservation purposes."
} 
conservation contribution under $\S 170(\mathrm{~h})$ or the applicable regulations. The Belks referred to this latter provision as a "savings clause." They argued that, if the Fourth Circuit found that the substitution provision violated the requirements of $\S 170(\mathrm{~h})$, the savings clause would render the substitution provision inoperable, thus making the easement eligible for the deduction. In other words, the Belks argued that the savings clause would operate to negate a right clearly articulated in the easement (the right to substitute property), but only if triggered by an adverse determination by the court.

The Fourth Circuit dismissed this argument, noting that the Belks were asking the court to employ the savings clause to rewrite the easement in response to the court's holding, which the court was unwilling to do. The court refused to condone such "trifling with the judicial process." The court also explained that holding for the Belks "would dramatically hamper the Commissioner's enforcement power. If every taxpayer could rely on a savings clause to void, after the fact, a disqualifying deduction....enforcement of the Internal Revenue Code would grind to a halt."

The Fourth Circuit also rejected the Belks' "last-ditch" argumentthat the savings clause was designed "to accommodate evolving...interpretation of Section 170(h)" - explaining

the statutory language of $\S 170(\mathrm{~h})(2)(\mathrm{C})$ has not "evolved" since the provision was enacted in $1980 \ldots$. The simple truth is this: the Easement was never consistent with $\S 170(\mathrm{~h})$, a fact that brings with it adverse tax consequences. The Belks cannot now simply reform the Easement because they do not wish to suffer those consequences.

e. Balsam Mountain. In Balsam Mountain, the Tax Court held that a conservation easement that authorized the parties, for a period of up to five years, to remove up to $5 \%$ of the land from the easement in exchange for protecting a similar amount of contiguous land was not eligible for a deduction under $\S 170(\mathrm{~h})$.

(i) The Easement. The easement at issue in Balsam Mountain, which was granted to the North American Land Trust (NALT) on 22 acres in North Carolina, allowed the landowner to, for five years following the donation, make alterations to the boundaries of the area protected by the easement, subject to the following conditions:

- the total amount of land protected by the easement could not be reduced,

- land added to the easement had to be contiguous to the originally protected land, 
- land added to the easement had to, in NALT's reasonable judgment, make an equal or greater contribution to the easement's conservation purpose,

- the "location and reconfiguration of a boundary" could not, in NALT's judgment, result in any material adverse effect on the easement's conservation purposes, and

- no more than $5 \%$ of the originally protected land could be removed from the easement as a result of such alterations.

(ii) Belk Not Distinguishable. Based on Belk, the Tax Court held that the Balsam Mountain easement was not "a restriction (granted in perpetuity) on the use which may be made of the real property" as required by $\S 170(\mathrm{~h})(2)(\mathrm{C})$ and, thus, was not eligible for a deduction. The donor argued that Belk was distinguishable because the Belk easement allowed for the substitution of all of the land originally protected by the easement, while the Balsam Mountain easement allowed for the substitution of only $5 \%$ of the originally protected land. The Tax Court was not persuaded. While the court agreed that the Belk and Balsam Mountain easements were different, it said "the difference does not matter." For five years following the donation, the donor, with the approval of NALT, could change the boundaries of the area protected by the easement (i.e., extinguish the original easement in part without satisfying the judicial extinguishment, impossibility or impracticality, or proceeds requirements). Accordingly, the easement was not an interest in an identifiable, specific piece of real property and, thus, was not deductible.

(iii) The holdings in Belk and Balsam Mountain prohibiting swaps are consistent with Carpenter $I$ and $I I$, in which the Tax Court held that extinguishment of a tax-deductible easement requires a judicial proceeding. Removing land from a conservation easement, whether in connection with a swap or otherwise, constitutes an extinguishment of the easement with regard to the removed land. It allows the removed land to be used for previously prohibited purposes, such as development, thus permitting the conservation values of the removed land, which had previously been protected in perpetuity, to be destroyed. The holdings in Belk and Balsam Mountain are also consistent with Congress's admonition in the legislative history "that provisions allowing deductions for conservation easements should be directed at the preservation of unique or otherwise significant land areas or structures," as well as the detailed threshold conservation purpose and other qualification 
and valuation requirements that must be met to be eligible for a deduction under $\S 170(\mathrm{~h}){ }^{83}$

f. Bosque Canyon Ranch. In Bosque Canyon Ranch, the Fifth Circuit majority vacated the Tax Court's holding that two conservation easements that permitted 47 unencumbered 5-acre homesites to be moved around the properties subject to the easements with the approval of the holder (North American Land Trust, or NALT) violated $\S 170(\mathrm{~h})(2)(\mathrm{C})$ 's "granted in perpetuity" requirement. The Tax Court determined that, as in Belk, the easements permitted property that was originally protected by the easements to lose that protection. The Fifth Circuit majority held that Belk was distinguishable for the following reasons.

- The easements allowed only the homesite parcels' boundaries to be changed and then only (1) within the tracts that are subject to the easements and (2) without increasing the acreage of the homesite parcel in question. The easements did not allow any change in the exterior boundaries of the easements or in their acreages. Thus, neither the exterior boundaries nor the total acreage of the easements would ever change: only the lot lines of one or more the five-acre homesite parcels were potentially subject to change and then only (1) within the easements and (2) with NALT's consent.

- The IRS's expert reportedly confirmed that the unencumbered homesite parcels had roughly the same per-acre value as the rest of the ranch that was encumbered by the easements. Thus, changing the boundaries of some of the homesite parcels would not return any value to the easement donors.

- The development plan for the ranch at the time of the trial indicated that (1) the vast majority of the homesites would be tightly clustered, largely contiguous, and located in the northernmost tip of the ranch; (2) together, the homesites closely resembled a typical suburban subdivision; (3) almost every homesite shared one or two common side line boundaries with one or more other homesites; and (4) most homesites were located on or in close proximity to the only road inside the easements, which road provided the sole access to the nearest public roads. Given this subdivision-like layout and the homesites' contiguity or close proximity to each other and to the only interior road providing ingress and egress to and from the public roads, "the plan visually eschewed any realistic likelihood of significant future changes in homesite location - at most, only theoretical or hypothetical changes."

${ }^{83}$ S. Rep. No. 96-1007, 1980-2 C.B. 599, at 603. See also supra note 25 and accompanying text, discussing IRS General Information Letter regarding swaps 
The majority also determined that any homesite parcel adjustments would be "de minimis" and "common-sense reasoning" indicated "that an easement may be modified to promote the underlying conservation interests." Finally, the majority held that "the usual strict construction of intentionally adopted tax loopholes is not applicable to grants of conservation easements made pursuant to $\S 170(\mathrm{~h})$ " and, instead, "the ordinary standard of statutory construction" should apply.

Fifth Circuit Judge Dennis issued a strong dissent in Bosque. He pointed out that the statutory requirement of a qualified appraisal would be rendered meaningless if a donor were permitted to change the boundaries of a conservation easement after the deduction was claimed. He disagreed that homesite parcel adjustments would constitute de minimis changes, explaining that there is no time limit within which the homesite modifications must occur and there is no limit upon the distance or the number of times a homesite can be relocated within the outer boundaries of the tract.

Judge Dennis argued that the Bosque easement is not distinguishable from the Belk easement because the forty-seven homesites were not a part of the land protected by the conservation easement. By permitting changes to the location of the homesite parcels, the easement authorized the removal of previously-protected conservation habitat from the easement and conversion of that habitat into residential development. In other words, the substitutions would change "the real property" that is subject to the easement.

Judge Dennis also rejected reliance on the existing development plan for the ranch, focusing instead on what could be done over the perpetual life of the conservation easement. He noted:

there is nothing in the modification provision that would stop the limited partners from later deciding that they would rather not be organized as a stereotypical subdivision and spread the sites across the tract...there is nothing to prevent a limited partner from seeking modification of his or her homesite even after a ranch home has been constructed...

Judge Dennis further pointed out that there was nothing in the record to suggest that the movable-homesite provision was designed to promote conservation interests. Rather, it appeared that the provision would more likely be used to benefit the partnerships and homeowners rather than conservation goals. He explained that, because most of the homesites are grouped together as a typical residential subdivision in the plan, they are not as valuable for wildlife conservation purposes as land within the heart of the 3,744-acre tract, and, thus, the swap of a homesite for a five-acre tract 
of initially-protected land would in most instances be detrimental to conservation.

As for the fact that NALT had to approve movement of the homesites, Judge Dennis explained:

Congress did not intend for possibly enormous tax deductions to be based on the likelihood of continued agreement between the donortaxpayer and the non-profit donee as to the land designated as subject to the conservation easement; rather, it specifically and unequivocally required that a qualified conservation easement be perpetual.

And, citing the Supreme Court's opinion in INDOPCO, Inc. v. Commissioner, Judge Dennis noted the well-established rule that tax deductions are a matter of legislative grace and are therefore "strictly construed and allowed only as there is a clear provision therefor." $84 \mathrm{He}$ explained that, contrary to the majority's assertion, this rule applies and has been applied in other circuits to a deduction for the donation of a conservation easement. ${ }^{85}$

The impact of the Fifth Circuit majority's holding in Bosque is likely to be limited given that (i) it is contrary to the Fourth Circuit's holding in Belk, (ii) it was based on very specific and unusual facts, (iii) the rule of construction applied by the majority differed from that applied in other circuits to $\S 170(\mathrm{~h})$ and to charitable deductions generally, (iv) there was a strong dissent, and (v) in Pine Mountain II, discussed immediately below, the Tax Court expressly declined to follow Bosque in cases not appealable to the Fifth Circuit.

g. Pine Mountain II. In Pine Mountain II, the Tax Court held that two conservation easements that allowed residential "building areas" to be moved or identified following the easements' donation, subject to the holder's approval, did not qualify for a deduction because neither easement was a "restriction (granted in perpetuity) on the use which may be made of the real property" as required by $\S 170(\mathrm{~h})(2)(\mathrm{C})$. The Tax Court held that the two easements were analogous to the easements in Belk, Balsam Mountain, and Bosque, and the court expressly declined to follow the Fifth Circuit's majority opinion in Bosque, instead relying on its own analysis in

\footnotetext{
${ }^{84}$ INDOPCO, Inc. v. Commissioner, 503 U.S. 79, 84 (1992).

${ }^{85}$ See Minnick v. Commissioner, 796 F.3d 1156, 1159 (9th Cir.2015); Belk v. Commissioner, 774 F.3d 221, 225 (4th Cir.2014); Scheidelman v. Commissioner, 755 F.3d 148, 154 (2d Cir.2014); Esgar Corp. v. Commissioner, 744 F.3d 648, 653 (10th Cir.2014). The strict-construction rule of INDOPCO has also been applied to charitable deductions generally. See, e.g., Zavaldi v. Commissioner, 793 F.3d 866 (8th Cir.2015) (charitable income-tax deduction); Galloway v. United States, 492 F.3d 219 (3d Cir.2007) (charitable estate tax deduction); Hewitt v. Commissioner, 166 F.3d 332 (4th Cir.1998) (charitable income-tax deduction; " "the taxpayer seeking the benefit of a deduction must show that every condition which Congress has seen fit to impose has been fully satisfied"').
} 
Bosque and Fifth Circuit Judge Dennis's dissent in Bosque. The Tax Court explained that appeal of its decision in Pine Mountain would be to the Eleventh Circuit, and the Tax Court is not bound to follow a Fifth Circuit holding in cases appealable in other circuits. ${ }^{86}$

The Tax Court further held that neither the reserved rights nor the amendment clause included in a third easement meant that the conservation purpose of that easement was not protected in perpetuity, and allowed a deduction for the donation of that easement.

Tax Court Judge Morrison published a strong dissent taking issue with various of the Tax Court majority's arguments. Given the dissent and the loss of sizable deductions by the taxpayer, ${ }^{87}$ it is likely that this case will be appealed and, thus, the Tax Court's holdings should not be viewed as the final word on these issues.

(i) Background. Pine Mountain involved a developer's donation of three conservation easements to the North American Land Trust (NALT). The easements, donated in 2005, 2006, and 2007, encumbered relatively small portions (collectively approximately $20 \%$ ) of a large tract of land slated for development near Birmingham, Alabama (6,224 acres).

- The 2005 easement encumbered approximately $47 \%$ of one parcel and consisted of approximately 560 mostly contiguous acres. Among other significant rights, the 2005 easement reserved to the developer (and the developer's successors) the right to construct a single family residence and associated structures within each of ten building areas, each as large as one acre. ${ }^{88}$ While Exhibit $\mathrm{C}$ of the easement situated the building areas around a man-made lake, the 2005 easement permitted the building areas to be relocated anywhere on the encumbered land, provided the relocation "shall not, in NALT's 'reasonable judgment,' adversely affect conservation purposes."

- The 2006 easement encumbered approximately 500 acres consisting of seven noncontiguous plots within three parcels, and the encumbered area constituted $17.6 \%$ of the total acreage of the parcels. Among other

\footnotetext{
${ }^{86}$ This is based on the "Golsen rule," established by Golsen v. Commissioner, 54 T.C. 742, 756-757 (1970), aff'd, 445 F.2d 985 (10th Cir. 1971).

${ }^{87}$ At trial, the taxpayer claimed that it was entitled to a collective deduction of $\$ 88.26$ million for the donation of the 2005 and 2006 easements. This was considerably in excess of the \$29.276 million the taxpayer had claimed on its tax return with respect to those easements.

${ }^{88}$ Other rights reserved to the developer include the right to construct ten 5,000-square foot barns each of which could include a dwelling, another barn, a riding stable, and indoor riding ring, two scenic overlooks that could involve treeclearing, fourteen piers and boat launches, five ponds, access roads and driveways, raised walkways, hunting stands and blinds, and wells.
} 
significant rights, ${ }^{89}$ the 2006 easement reserved to the developer (and the developer's successors) the right to construct a single family residence and associated structures within each of six building areas, each as large as one acre. The 2006 easement did not specify the location of the building areas and placed no limitation on where they could be located, except to state that NALT had to approve the locations and could withhold its approval if it believed a proposed location would result "in any material adverse effect on the Conservation Values or Conservation Purposes."

- The 2007 easement encumbered approximately 240 acres consisting of seven noncontiguous plots within three parcels, and the encumbered area represented $7.5 \%$ of the total acreage of the parcels. The developer did not reserve any residential development rights in the 2007 easement, but did reserve certain other rights (e.g., the right to construct a water tower and underground pipelines that could service other properties; the right to construct fences, raised walkways, service vehicle trials, and utility installations; and the right to hunt, trap, and otherwise harvest fish and wildlife on the property).

(ii) Movable Building Areas. In holding that the 2005 and 2006 easements were analogous to the easements in Belk, Balsam Mountain, and Bosque, and thus not eligible for a deduction, the Tax Court noted that its thinking was well captured by the "Swiss cheese" metaphor used by Fifth Circuit Judge Dennis in his dissent in Bosque. The Tax Court explained that one must imagine the area encumbered by an easement as a large slice of Emmenthaler cheese. The cheese represents the real property initially restricted by the easement; the holes represent the zones reserved for commercial or residential development; and $\S 170(\mathrm{~h})(2)(\mathrm{C})$, which requires that an easement attach to a "defined parcel of real property" or a "single, immutable parcel," bars the putting of any new holes in the cheese.

The court explained that a developer could consider two techniques for reserving the right to put new holes in the cheese.

- First, the developer could put new holes in the cheese and make up for it by adding an equal amount of previously unprotected land to the conservation area. That was the pattern in Belk.

- Alternatively, the developer could put new holes in the cheese and make up for it by plugging the same number of holes elsewhere in the conservation area. That was the pattern in Bosque and in Pine Mountain.

\footnotetext{
${ }^{89}$ These rights were to some extent similar to those reserved in the 2005 easement (see supra note 88 ) and further included the right to construct a water tower and underground pipelines that could service residential and commercial development on portions of the larger property not protected by a conservation easement.
} 
The court explained that, in each instance, the acreage subject to the easement remains exactly the same. But in each instance, the developer has achieved the impermissible objective of putting new holes in the cheese, i.e., subjecting to commercial or residential development land that was supposed to be protected in perpetuity from such development. ${ }^{90}$ The court explained that reserved development rights in Belk, Bosque, and Pine Mountain were all paths to the same bottom line - the developer retaining the right to develop a portion of the originally-protected conservation area by substituting other property. Compare Butler, discussed in Part II.A.4. above, in which the location of the building sites was fixed by the conservation easement deed because a map stipulating the placement of building sites in locations that were consistent with preservation of the conservation purposes was found to be incorporated into the deed and binding under Georgia law.

The Tax Court determined that the 2007 easement, which did not reserve to the developer any residential development rights, did not suffer from the same fatal flaw as the 2005 and 2006 easements because it did not permit the developer to place any new holes in the cheese.

Tax Court Judge Morrison, in his dissenting opinion, argued that the 2005 and 2006 easements were distinguishable from the easements in Bosque because the homesite parcels in Bosque were completely free of the easements while the building areas in Pine Mountain allowed residential development but were otherwise subject to the easements' restrictions (that is, he argued that the easements attached to "defined parcels"). Judge Morrison argued that the relative weakness of the easement deeds' restrictions in the building areas was relevant only to whether the easements protected conservation purposes in perpetuity as required by $\S$ $170(\mathrm{~h})(5)(\mathrm{A})$.

The Tax Court majority said that the fact that the building areas in Pine Mountain were technically encumbered by the easements, while the homesites in Bosque were not, was a distinction without a difference. The majority explained that, by permitting the building areas to be relocated to other sections of the conservation area, the easements allowed the developer to subject to residential development land that was supposed to be protected in perpetuity from any form of development. The court also explained that, although the building areas were not literally exempt from the easements,

\footnotetext{
${ }^{90}$ The court also explained that, because the 2005 easement permits Pine Mountain to construct a variety of other buildings (at least eleven of which may include additional living quarters) anywhere within the conservation area, Pine Mountain had reserved the right, not only to put new holes in the cheese for the ten residences, but to put twenty acres of extra holes in the cheese for structures appurtenant to those residences. With regard to the 2006 easement, where the location of the six building areas was not identified in the easement at the time of the donation, the court explained that it was impossible to identify, when the easement was granted, the "real property" that would actually be restricted from development because the residential lots could literally be placed anywhere on the property. As a result, the perpetual use restriction did not attach at the outset "to a defined parcel of real property" or to "a single, immutable parcel."
} 
they were not subject to the easements in any meaningful sense because they permitted uses that were antithetical to the habitat and open space protection conservation purposes of the easements. The court concluded that it made no difference to anyone--the land trust, the developer, or the homeowners--whether the building areas were encumbered (or not) by the easements; either way the developer had the right to construct residential development in those areas and that development was exempt, for all practical purposes, from the restrictions imposed by the easements.

(iii) Extensive Reserved Rights. The IRS argued that the conservation purposes of the Pine Mountain easements were not "protected in perpetuity" because the extensive rights reserved to the developer (and the developer's successors) permitted the properties to be used in ways inconsistent with those conservation purposes. Because the Tax Court majority determined that the 2005 and 2006 easements did not qualify for a deduction due to the movable building areas, this argument was relevant only to the 2007 easement and the majority held for the taxpayer on this issue. A NALT biologist presented testimony that none of the reserved rights in the 2007 easement would impair the conservation purposes and, as in Glass and Butler (discussed in Part II.A.4), the IRS failed to provide any evidence to the contrary. The Tax Court held that since there was no conflicting testimony as to whether the conservation purposes of the 2007 easement were protected in perpetuity, it found that those purposes were so protected. This holding and the holdings in Glass and Butler signal that, regardless of the conservation purposes at issue, to succeed with this argument, the IRS must hire its own experts to testify as to why, upon full exercise of all reserved rights, the conservation purposes of an easement will not be protected in perpetuity.

Because Judge Morrison in his dissent determined that the 2005 and 2006 easements were not rendered nondeductible as a result of the movable building areas, and the 2007 easement was not rendered nondeductible by the amendment clause (as discussed below), he viewed the "too many reserved rights" argument as relevant to all of the Pine Mountain easements. He held that the 2005 and 2007 easements did not permit uses inconsistent with conservation purposes, but the 2006 easement did. With regard to the 2005 easement, Judge Morrison relied on the testimony of NALT's biologist that the man-made lake, the ten building areas around it, and the other extensive reserved rights would not affect the conservation value of the easement. He also noted that the "dense clustering" of the ten houses around the lake would not appreciably affect the scenic value of the protected land.

With regard to the 2006 easement, where the location of the building areas was not specified in an exhibit to the easement, Judge Morrison felt differently. He found that the right to build six houses was inconsistent with 
the habitat and scenic enjoyment conservation purposes because he did not know where the building areas for the six houses would be. He noted that, for the 2005 easement, the IRS had the opportunity to present evidence that the initial locations of the building areas were inconsistent with conservation purposes. He said there was no such opportunity regarding the 2006 easement. Rather "[t]here is only a vague hope that NALT will exercise its veto over boundary areas that would undermine the conservation purposes." This hope, he said, was not enough to convince him that the right to build in the yet-to-be-specified building areas is consistent with the conservation purposes. He did not explain, however, why developer's ability to relocate the ten building areas in the 2005 easement, which was also subject to only the "vague hope" that NALT would exercise its veto power to prevent the undermining of conservation purposes, did not similarly disqualify that easement.

(iv) Amendment Clause. The IRS argued that the amendment clause included in the 2007 easement, which authorized the parties to agree to amendments that are "not inconsistent with the Conservation Purposes," enabled the parties to amend the easement in ways that would clearly violate the statutory perpetuity requirements, such as by reducing the size or otherwise modifying the boundary of the protected area or by permitting residential construction within the protected area. The Tax Court majority rejected this argument on three grounds.

- First, the Tax Court noted that it was hard to imagine how NALT could conscientiously find such amendments to be "consistent with the Conservation Purposes" set forth in the easement, and that an easement's restrictions should not be deemed "nonperpetual" because of the risk that the qualified organization might be unfaithful to the charitable purposes on which its exemption rests. Citing to Simmons, the court noted that "[a]ny donee might fail to enforce a conservation easement, with or without a clause stating that it may consent or abandon its rights, and a tax-exempt organization would do so at its peril."

- Second, the Tax Court's noted that a conservation easement involves a conveyance, which is a form of contract and, generally speaking, the parties to a contract are free to amend it, whether or not they explicitly reserve the right to do so. According to the court, the amendment clause could thus reasonably be regarded as a limiting provision, confining the permissible subset of amendments to those that would not be "inconsistent with the Conservation Purposes" of the easement.

- Third, the Tax Court noted that the IRS's argument would apparently prevent the donor of any easement from qualifying for a deduction under $\S 170(\mathrm{~h})$ if the easement permitted amendments, and the court said it found no support for that argument in the statute, 
the regulations, the decided cases, or the legislative policy underlying the statute.

Dissenting Tax Court Judge Morrison disagreed with the Tax Court majority on this issue as well. He noted that the amendment clause included in the 2007 easement states that the developer and NALT "recognize that circumstances could arise which would justify the modification of certain of the restrictions contained in this Conservation Easement," and "[t]o this end," NALT and the owner of the land in the conservation area have the right to agree to amendments that are not inconsistent with the conservation purposes. Judge Morrison argued that because the amendment clause authorizes only modification of "the restrictions," it limits the parties to modifying the specific restrictions in the deed and, thus, would not permit the parties to modify the exterior boundary of the easement.

Judge Morrison also noted that the Tax Court majority made unfounded assumptions about NALT's behavior. He explained that, while it is true that the amendment clause provides that no amendment can be agreed to by NALT unless the amendment is not inconsistent with the conservation purposes, this does not require NALT to review proposed amendments to see whether the amendments comply with $\S 170(\mathrm{~h})(2)(\mathrm{C})$, which does not refer to conservation purposes and requires only that an easement to be "a restriction (granted in perpetuity) on the use which may be made of the real property." Judge Morrison argued that the Tax Court majority mixed up the "granted in perpetuity" and "protected in perpetuity" tests and made the unsupported assumption that NALT would refuse to consent to amendments that would bar a deduction for the donation of the easement under section $170(\mathrm{~h})(2)(\mathrm{C})$ (i.e., amendments that would change the boundary of the easement), and this "unrealistically supposes that NALT will essentially act as a tax compliance officer."

Judge Morrison further argued that the Tax Court majority made "radical claims" about the consequences of the IRS's interpretation of the amendment clause. The majority asserted that the clause in the 2007 easement was similar to the amendment provisions in many other conservation easement deeds and supported this assertion by citing an amicus brief filed by the Land Trust Alliance in different case. Judge Morrison pointed out that the amendment clause in the easement involved in that other case was different from the amendment clause in the Pine Mountain easements and, thus, that amicus brief was irrelevant to the Pine Mountain Case. Judge Morrison also explained that the Land Trust Alliance amicus briefs (he had refused to accept the one filed in Pine Mountain) made unsubstantiated claims about particular amendment clauses being "widely used" and, thus, were unreliable and should not affect the court's analysis of the amendment clause. 
Finally, Judge Morrison argued that, in wrapping up its discussion of the amendment clause, the Tax Court majority misleadingly summarized the IRS's argument by stating that the IRS's argument "would apparently prevent the donor of any easement from qualifying for a charitable contribution deduction under section $170(\mathrm{~h})$ if the easement permitted amendments." Judge Morrison noted that, actually, the IRS had argued only that the particular amendment clause in the Pine Mountain easement deeds prevented the donor of those easements from qualifying for a deduction. The IRS did not attack all amendment clauses in all easement deeds. Judge Morrison noted that amendment clauses can and do differ, and that the courts must interpret each clause to see whether it satisfies $\S 170(\mathrm{~h})$ 's requirements.

Although not mentioned by Judge Morrison in his dissent, the argument that the 2007 easement involved a conveyance, which is a form of contract, and generally speaking the parties to a contract are free to amend it, whether or not they explicitly reserve the right to do so, makes no sense in the taxdeductible conservation easement context. First, that argument ignores the fact that tax-deductible conservation easements are by definition charitable gifts (they have to be in order to be eligible for a deduction), and under state law charitable organizations are generally not free to alter the terms of a charitable gift made for a specific purpose except to the extent that the organization is granted the power to do so in the terms of the gift. ${ }^{91}$ Accordingly, an amendment clause is not a limiting provision; it does not constrain an otherwise unlimited power to amend. Rather, it is in empowering provision-granting the donee certain rights to alter the terms of the gift that the donee otherwise would not have. Moreover, if an easement were simply a contract that could be amended by the current landowner and donee at any time, the amendment provision itself could be amended, and thus would not be a limiting provision. It also would be impossible to comply with the various requirements in $170(\mathrm{~h})-\mathrm{e} . \mathrm{g}$., the restriction on transfer, judicial extinguishment, and payment of a minimum proportionate share of proceeds to the holder upon extinguishment requirements - because the clauses included in a deed to satisfy those requirements could be amended at any time.

\section{Reserved Development Rights: Regulations and Examples.}

a. Treasury Regulations. The following Treasury Regulations, among others, limit reserved development rights.

(i) Treasury Regulation $\S 1.170 \mathrm{~A}-14(\mathrm{~d})(4)(\mathrm{v})$ contains a limitation on the reservation of rights in an open space easement - a deduction will not be allowed "if the terms of the

\footnotetext{
${ }^{91}$ See Part II.A.10 below, discussing the interaction between federal and state law.
} 
easement permit a degree of intrusion or future development that would interfere with the essential scenic quality of the land or the governmental conservation policy being furthered by the donation."

(ii) Treasury Regulation $\S 1.170 \mathrm{~A}-14(\mathrm{e})(2)$ provides that "a deduction will not be allowed if the contribution would accomplish one of the enumerated conservation purposes but would permit destruction of other significant conservation interests" (the "no inconsistent use" requirement). ${ }^{92}$

(iii) Treasury Regulation $\S 1.170 \mathrm{~A}-14(\mathrm{~g})(1)$ provides that "any interest in the property retained by the donor...must be subject to legally enforceable restrictions...that will prevent uses of the retained interest inconsistent with the conservation purposes of the donation" (the "general enforceable in perpetuity" requirement).

b. Examples 3 and 4. The Treasury Regulations provide two examples addressing "future development" in an open space easement. ${ }^{93}$

(i) Example 3 involves Greenacre, a 900-acre parcel of woodland, rolling pasture, and orchards on the crest of a mountain, all of which is clearly visible from a nearby national park. The highest and best use of Greenacre is as a subdivision of 40-acre tracts (potentially twenty-two residential lots). The landowner wishes to donate a scenic easement on Greenacre and "would like to reserve the right to subdivide Greenacre into 90acre parcels with no more than one single-family home allowable on each parcel." Example 3 concludes that "[r]andom building on the property, even as little as one home for each 90 acres [a total of only ten homes], would destroy the scenic character of the view. Accordingly, no deduction would be allowable."

(ii) Example 4 assumes the same facts as Example 3, except:

- "not all of Greenacre is visible from the park"

- "the deed of easement allows for limited cluster development of no more than five nine-acre clusters (with four houses on each cluster) located in areas

\footnotetext{
92 The regulations provide, as an example, that the preservation of farmland will not qualify for a deduction if, under the terms of the easement, a significant naturally occurring ecosystem could be injured or destroyed by the use of pesticides in the operation of the farm. Treas. Reg. $\S 1.170 \mathrm{~A}-14(\mathrm{e})(2)$. A use that is destructive of conservation interests is permitted only if the use is necessary for the protection of the conservation interests that are the subject of the contribution, such as allowing site excavation that may impair scenic values on property preserved as an archaeological site. Treas. Reg. $\S$ $1.170 \mathrm{~A}-14(\mathrm{e})(3)$.

93 Treas. Reg. § 1.170A-14(f), Examples 3 and 4.
} 
generally not visible from the national park and subject to site and building plan approval by the donee organization in order to preserve the scenic view from the park,"

- "[t]he donor and the donee have already identified sites where limited cluster development would not be visible from the park or would not impair the view," and

- "[o]wners of homes in the clusters will not have any rights with respect to the surrounding Greenacre property that are not also available to the general public."

Example 4 concludes that the donation qualifies for a deduction.

Example 3 involves rights to build that could be exercised by the landowner anywhere on the property. The donation is not eligible for a deduction, despite the easement reducing the number of potential residential lots from twenty-two to ten, because such rights could (i) interfere with the essential scenic quality of the land or the governmental conservation policy being furthered by the donation, ${ }^{94}$ (ii) permit destruction of other significant conservation interests, ${ }^{95}$ and (iii) permit uses of the retained interest inconsistent with the conservation purposes of the donation. ${ }^{96}$

Example 4 indicates that, even if the number of permitted homes is increased (from ten to twenty), if the conditions specified in the Example are met, the donation will be eligible for a deduction. Given that Example 4 provides that the "donor and the donee have already [i.e., at the time of the donation] identified sites where limited cluster development would not be visible from the park or would not impair the view," the Example does not appear to give the donee the discretion to determine the location of such sites at some later date. Rather, to give each of the specified conditions in Example 4 meaning, the Example could be interpreted to (i) give the donee the discretion to later approve the site and building plans of the four homesites within each cluster (rather than the sites of the clusters themselves) or (ii) give the donor and donee the right to identify, at the time of the donation, more than five possible sites "where limited cluster development would not be visible from the park or would not impair the view," thus giving the donor and the donee some flexibility to later choose the five cluster sites from the more than five possible sites identified on the date of the donation..$^{97}$

Identification of the possible sites of cluster development at the time of the donation is also consistent with the Treasury Regulation requirements noted

94 Treas. Reg. $\$ 1.170 \mathrm{~A}-14(\mathrm{~d})(4)(\mathrm{v})$.

95 Treas. Reg. § 1.170A-14(e)(2).

${ }^{96}$ Treas. Reg. $\S 1.170 \mathrm{~A}-14(\mathrm{~g})(1)$.

${ }^{97}$ This is not an uncommon technique that is used to give donors some flexibility, while ensuring that the extent of the reserved rights can be assessed by the IRS and the courts at the time of the donation. 
above because it would allow the IRS (and, if litigated, a court) to assess whether - at the time of the donation - the reserved development rights would (i) interfere with the essential scenic quality of the land or the governmental conservation policy being furthered by the donation, (ii) permit destruction of other significant conservation interests, or (iii) permit uses of the retained interest inconsistent with the conservation purposes of the donation. Alternatively, interpreting Example 4 to permit the donee to determine the sites of the five cluster developments at some point after the donation is made would render those threshold requirements meaningless because the IRS and the courts would have no way to assess, at the time of the donation, whether the easement satisfied those requirements. Similar to the Fourth Circuit's reasoning in Belk (discussed in Part II.A.6 above), the purpose of these threshold requirements is to enable the Commissioner, not the donee or donor, to verify that the reserved rights in a conservation easement will not (i) interfere with the essential scenic quality of the land or the governmental conservation policy being furthered by the donation, (ii) permit destruction of other significant conservation interests, or (iii) permit uses of the retained interest inconsistent with the conservation purposes of the donation. Allowing the holder to identify or relocate building areas at some point following the donation places taxpayers beyond the reach of the Commissioner in this regard. ${ }^{98} \mathrm{Had}$ Congress intended to grant holders the discretion to approve the location of building areas and other intensive use of protected lands after the donation of an easement, $\S 170(\mathrm{~h})$ and the Treasury Regulations would be much shorter and simpler. ${ }^{99}$

8. Addressing Reserved Development Rights. Reserved development rights could be addressed in a number of ways:

a. The parties could identify the building areas in the conservation easement deed.

b. The parties could identify more building areas in the conservation easement deed than are permitted to be used. For example, the easement might reserve to the grantor the right to build two additional single-family residences on the subject property, each in a one-acre building area, but four possible sites for the building areas may be identified in the deed. The deed would also provide that the unused sites will be retired once the reserved rights have been exercised. ${ }^{100}$

\footnotetext{
${ }^{98}$ Allowing the holder to identify or relocate building areas at some point following the donation would also further complicate an already challenging appraisal process, as the appraiser, who is not an attorney or an employee of the donee, would be required to try and determine where on the subject property the holder might (and might not) permit the building areas to be located.

${ }^{99}$ See supra note 1 and accompanying text (explaining that the Treasury Regulations are based, in large part, on the detailed Senate Report describing § 170(h)).

100 The deed might provide that the unused sites will remain extant even after the reserved rights have been exercised, to be used if a future property owner decides to relocate a residence. However, given the difficulties associated with
} 
c. The parties could designate all conservation sensitive areas as "no-build" areas," and the remaining portions of the subject property as "build areas." However, the no-build areas would have to be more than just token setbacks; they would have to be extensive enough to protect the property's conservation values.

d. The parties could exclude the building areas from the legal description of the property encumbered by the conservation easement. A significant drawback to this approach is that the holder would not be able to limit intensive uses of the excluded areas, and those uses could negatively impact the protection of conservation values on the encumbered land. Excluding the building areas from the easement also might reduce the donor's donation as a result of the "entire contiguous parcel" valuation rule, which is designed to reduce an easement donor's deduction to the extent that the donation increases the value of contiguous property owned by the donor or a member of the donor's family. ${ }^{101}$

In addition, the conservation easement and the baseline documentation should explain why the location of each identified building site or build area will not adversely impact the property's conservation values or the conservation purposes of the easement.

9. State Law Can Render Conservation Easements Nondeductible. In Wachter, the Tax Court held that North Dakota law, which limits the duration of easements created after July 1, 1977, to a maximum of 99 years, precludes conservation easement donors in the state from qualifying for a deduction under $\S 170(\mathrm{~h})$ because easements in North Dakota cannot be granted "in perpetuity."

a. Federal Law Controls. The Tax Court in Wachter reiterated the fundamental principle that, while state law determines the nature of property rights, it is federal law that determines the federal tax treatment of those rights. Wachter confirmed that state law can render all conservation easement donations in a state ineligible for the federal deduction if state law prevents conservation easements from complying with federal requirements.

Some states have considered making changes to their state codes that could render conservation easements in the state ineligible for federal tax

restoration of developed sites to their natural condition, the possible negative impacts on conservation values might be too extensive to warrant a deduction for the donation.

${ }^{101}$ See Treas. Reg. $\S 1.170 \mathrm{~A}-14(\mathrm{~h})(3)(\mathrm{i})$. The donor might also consider donating two easements, one nondeductible easement encumbering the designated building areas, and a second deductible easement encumbering the remaining property that satisfies all federal tax law requirements. While this could address the concern about intensive uses of the unencumbered areas, the conveyance of two easements would increase the expense and complexity of the transaction. For more on this and the option of excluding building areas from easement protections altogether, see the discussion of PBBM-Rose Hill in Part II.A.12 below. 
incentives. ${ }^{102}$ Potential easement donors and their advisors should be aware of this issue.

b. Wachter: Termination in 99 Years Not So Remote as to be Negligible. The taxpayers in Wachter argued that North Dakota's 99-year limitation should be considered the equivalent of a remote future event that does not prevent an easement from being considered perpetual. They cited Treasury Regulation $\S 1.170 \mathrm{~A}-14(\mathrm{~g})(3)$, which provides, in part, that:

[a] deduction shall not be disallowed ... merely because the interest which passes to, or is vested in, the donee organization may be defeated by the performance of some act or the happening of some event, if on the date of the gift it appears that the possibility that such act or event will occur is so remote as to be negligible.

The Tax Court in Wachter noted that the courts have construed the soremote- as-to-be-negligible standard to mean:

'a chance which persons generally would disregard as so highly improbable that it might be ignored with reasonable safety in undertaking a serious business transaction' or 'a chance which every dictate of reason would justify an intelligent person in disregarding as so highly improbable and remote as to be lacking in reason and substance.'

The Tax Court explained that the term "remote" refers to the likelihood of the event that could defeat the donee's interest in the gift. It then explained that the likelihood of the event in Wachter that could defeat the donee's interest in the charitable gifts of the conservation easements - expiration of the easements after 99 years - was not "remote." On the date of the donation of the easements, the court explained, it was not only possible, it was inevitable that the donee would be divested of its interests in the easements by operation of North Dakota law. Accordingly, the easements were not restrictions granted "in perpetuity" and, thus, were not deductible under $\S 170(\mathrm{~h})$.

10. Interaction Between Federal and State Law. Numerous courts have addressed the interaction between federal and state law in the conservation easement context. As noted in the discussions of Carpenter $I^{103}$ and Wachter ${ }^{104}$ above, while state law determines the nature of the property rights in an easement, it is federal law that determines the tax treatment of those rights. Thus, in determining whether an easement complies with federal tax law requirements, one

\footnotetext{
102 See, e.g., Keeping the Perpetual in Perpetual Conservation Easements, http://lawprofessors.typepad.com/nonprofit/2015/12/keeping-the-perpetual-in-perpetual-conservation-easements. html.

${ }^{103}$ See Part II.A.6 above.

${ }^{104}$ See Part II.A.9 above.
} 
must look to the terms of the deed and applicable state law to determine how a particular easement may, for example, be transferred, extinguished, or amended, and then ask whether the easement, so configured, satisfies federal tax law requirements.

a. In Belk III, the Fourth Circuit held that $\S 170(\mathrm{~h})$ "requires that the gift of a conservation easement on a specific parcel of land be granted in perpetuity to qualify for a federal charitable deduction, notwithstanding the fact that state law may permit an easement to govern for some shorter period of time." Thus, while an easement that grants restrictions for less than a perpetual term, like the easement at issue in Belk, may be a valid conveyance under state law, it will be ineligible for a deduction under federal law.

b. With the exception of North Dakota, which limits the duration of any easement created in the State to 99 years, it appears that the parties to a conservation easement can include provisions in the deed to comply with the federal tax law perpetuity requirements and, provided the easement is drafted appropriately, those provisions will be enforceable under state law even though they impose conditions on the transfer or extinguishment of the easement that are different from or more restrictive than those imposed by state law. As the Tax Court noted in Wachter, "[b]oth parties allege that the State law at issue here is unique because [North Dakota] is the only State that has a law that provides for a maximum duration that may not be overcome by agreement."

c. The drafters of the Uniform Conservation Easement Act, which has been adopted in just over half the states and the District of Columbia, ${ }^{105}$ specifically intended that the Act would allow parties to draft a conservation easement that would comply with federal tax law requirements. The drafters explained:

The Act enables the structuring of transactions so as to achieve tax benefits which may be available under the Internal Revenue Code, but parties intending to attain them must be mindful of the specific provisions of the income, estate and gift tax laws which are applicable. ${ }^{106}$

The Act enables parties to create a conservation easement of unlimited duration subject to the power of a court to modify or terminate the easement in accordance with the principles of law and equity.... Allowing the parties to create such easements also enables

\footnotetext{
105 See Nancy A. McLaughlin, Uniform Conservation Easement Act Study Committee Background Report (prepared for the Uniform Law Commission, June 11, 2017), available at https://www.uniformlaws.org/HigherLogic/System/DownloadDocumentFile.ashx?DocumentFileKey=dde6ced5-c42ef02a-ff3b-95ce0f53d3d6\&forceDialog $=0$.

${ }_{106}$ Unif. Conservation Easement Act, Prefatory Note, at 3 (2008).
} 
them to fit within federal tax law requirements that the interest be "in perpetuity" if certain tax benefits are to be derived. ${ }^{107}$

The Uniform Conservation Easement Act drafters also contemplated that the terms of a conservation easement could be enforced by the relevant state attorney general on behalf of the public if the holder failed to enforce the easement or agreed to an improper amendment or extinguishment:

the Act also recognizes that the state's other applicable law may create standing [to bring an action] in other persons. For example, independently of the Act, the Attorney General could have standing in his capacity as supervisor of charitable trusts, either by statute or at common law. ${ }^{108}$

d. In 1980, at the congressional hearings on proposed $\S 170(\mathrm{~h})$, in response to the Treasury's concern that charitable conservation organizations might not properly enforce conservation easements, nineteen land trusts submitted an Appendix to their testimony in which they acknowledged the status of tax-deductible conservation easements as "charitable grants," and noted the power and duty of courts of competent jurisdiction and state attorneys general to enforce such grants. ${ }^{109}$

e. In Carpenter I, the Tax Court held that the conservation easements at issue were restricted charitable gifts, or "contributions conditioned on the use of the gift in accordance with the donor's precise directions and limitations." Restricted gift status means that both the donor and the donee (and their successors) are bound by the terms of the easement deed under state law, including the provisions included in the deed to satisfy federal tax law requirements. Thus, if an easement deed is drafted appropriately, the provisions included in the deed governing transfer, amendment, and extinguishment should be binding on both parties (owner and holder) and enforceable by the state attorney general, even though the state enabling statute may contain different or less restrictive provisions addressing those actions. For example, if a conservation easement enabling statute provides that a conservation easement can be extinguished with the approval of a public official, that state law requirement must be satisfied in addition to the judicial extinguishment and division of proceeds requirements set forth in the easement deed to satisfy $\S 1.170 \mathrm{~A}-14(\mathrm{~g})(6)$.

\footnotetext{
${ }^{107}$ Unif. Conservation Easement Act, $\S 2$, Comment (2008).

${ }^{108}$ Unif. Conservation Easement Act, $\S 3$, Comment (2008). See also Part II.A.13 below, discussing the Tax Court Order in Hoffman Properties, which provides, in part, "it is undisputed that Ohio law empowers the AG to initiate a suit to enforce the terms of an easement if the holder neglects to do so...."

109 See Minor Tax Bills: Hearings Before the Subcomm. on Select Revenue Measures of the House Comm. on Ways and Means, 96 ${ }^{\text {th }}$ Cong. 238, 242 (1980) (Appendix to Testimony of French and Pickering Creeks Conservation Trust, the Brandywine Conservancy, and other Conservation Organizations in re H.R. 7318 on June 26, 1980).
} 
11. Sample Restriction on Transfer and Extinguishment Provisions. A conservation easement deed should include transfer and extinguishment provisions that comply with Treasury Regulation requirements. The following are sample provisions. ${ }^{110}$

\section{Article X. Transfer and Extinguishment}

\section{a. Restriction on Transfer. ${ }^{111}$}

(1) Grantee is prohibited from assigning or otherwise transferring this Easement, whether or not for consideration, unless:

(i) the transferee is, at the time of the transfer, a "qualified organization" and an "eligible donee," as those terms are defined in $\S 170(\mathrm{~h})$ of the Code and the regulations promulgated thereunder, and

(ii) Grantee, as a condition of the transfer, requires that the transferee agree in writing that the conservation purpose(s) that the contribution of this Easement was originally intended to advance will continue to be carried out.

Any subsequent transfer of this Easement shall also be subject to this paragraph.

(2) If Grantee shall cease to exist, or cease to be a "qualified organization" or an "eligible donee," as those terms are defined in $\S$ 170(h) of the Code and the regulations promulgated thereunder, and a prior transfer is not made in accordance with the requirements of this paragraph, then Grantee's rights and obligations under this Easement shall vest in such entity as a court of competent jurisdiction shall direct pursuant to the applicable laws of [State in which Property is located] governing charitable gifts, provided that the requirements of subparagraphs (1)(i) and (ii) of this paragraph shall be satisfied.

\section{b. Extinguishment; Proceeds. ${ }^{112}$}

(1) Grantor and Grantee agree that the donation of this Easement creates a property right that immediately vests in Grantee. Grantor and Grantee further agree that this property right has a fair market value that is at least equal to the proportionate value that this Easement, at the time of the gift, bore to the value of the Property as a whole (unencumbered by this Easement) at that time, and such

\footnotetext{
110 These sample provisions are drafted to comply with $\S 170(\mathrm{~h})$ and Treasury Regulation requirements. However, neither the IRS nor the courts have blessed these sample provisions. Readers are responsible for obtaining legal advice from their own legal counsel.

111 See Treas. Reg. $\S 1.170 \mathrm{~A}-14(\mathrm{c})(2)$. In the last sentence of this regulation, the cross-reference to (b)(3) should be to (b)(2), and the cross-reference to $(\mathrm{g})(5)$ (ii) should be to $(\mathrm{g})(6)$; the Treasury failed to update the cross-references when it finalized the proposed regulations in 1986.

112 See Treas. Reg. $§ 1.170 \mathrm{~A}-14(\mathrm{~g})(6)$.
} 
minimum proportionate value of Grantee's property right, expressed as a percentage (the "Minimum Percentage"), shall remain constant.

(2) This Easement can be extinguished in whole or in part (whether through release, termination, eminent domain, abandonment, swap, exchange, reconfiguration, or otherwise) only:

(i) in a judicial proceeding in a court of competent jurisdiction,

(ii) upon a finding by the court that a subsequent unexpected change in the conditions surrounding the Property has made impossible or impractical the continued use of the Property (or the portion thereof to be removed from this Easement) for conservation purposes, and

(iii) with a payment of proceeds to Grantee, calculated as provided in subparagraph (3) below, and all such proceeds shall be used by Grantee in a manner consistent with the conservation purposes of this gift.

(3) In the event of an extinguishment, Grantee shall be entitled to a share of the proceeds from a subsequent sale, exchange, lease, or involuntary conversion of the property removed from this Easement equal to the greater of:

(i) the Minimum Percentage of such proceeds or

(ii) the appraised value of this Easement (or portion of this Easement encumbering the property to be removed) immediately before and ignoring the extinguishment, calculated using before and after valuation methodology similar to that provided in Treasury Regulation $\S 1.170 \mathrm{~A}$ 14(h)(3)).

If Grantee, in Grantee's sole discretion, determines that the cost to Grantee of obtaining an appraisal of this Easement (or relevant portion thereof) at the time of extinguishment is likely to exceed any benefit to Grantee from obtaining such appraisal, or that the benefit of having such an appraisal prepared is so small as to be insignificant, Grantee may elect to receive the amount determined pursuant to (i) of this subparagraph (the "Minimum Percentage of such proceeds"). ${ }^{113}$

113 The "greater of" proceeds formula complies with federal tax law requirements because the Grantee will always receive at least the minimum proportionate (or floor) share of proceeds required by Treasury Regulation $\S 1.170 \mathrm{~A}-14(\mathrm{~g})(6)(\mathrm{ii})$. The "greater of" formula also helps to (i) ensure that the Grantee will receive the appreciation (if any) in the value of easement to be used "in a manner consistent with the conservation purposes of the original contribution" (i.e., to replace 
(4) If all or any part of the Property is taken under the power of eminent domain, Grantor and Grantee shall participate in appropriate proceedings at the time of such taking to recover the full value of their respective interests subject to the taking and all incidental or direct damages resulting from the taking. Grantee shall be entitled to compensation from the recovered proceeds pursuant to subparagraph (3) above. The respective rights of Grantor and Grantee set forth in this subparagraph shall be in addition to, and not in limitation of, any rights they may have at common law.

(5) For purposes of this Easement, any removal of any land from this Easement, however characterized, constitutes an extinguishment.

(6) All provisions of this Article shall survive any extinguishment of this Easement in whole or in part. Any attempted extinguishment of all or a portion of the Easement contrary to this paragraph shall be invalid.

c. Interaction With State Law. Grantor and Grantee are prohibited from exercising any power or discretion granted under state law regarding the transfer or extinguishment of this Easement that would be inconsistent with the provisions of this Easement, including the provisions in this Article, or the continued protection in perpetuity of the conservation values of the Property and the conservation purposes of this Easement.

12. Noncompliant Proceeds Clause. The courts have denied deductions for failure to meet the proceeds requirement of Treasury Regulation $\S 1.170 \mathrm{~A}-14(\mathrm{~g})(6)$ (ii) in two cases: Carroll and PBBM-Rose Hill.

a. Carroll. In Carroll, the Tax Court sustained the IRS's disallowance of approximately $\$ 650,000$ of carryover deductions claimed with regard to a conservation easement donation because the easement contained a noncompliant proceeds clause. The court explained that the minimum proportionate share of proceeds that must be payable to the holder of an easement following extinguishment is equal to the percentage determined by (i) the fair market value of the easement on the date of the gift, which is the numerator, over (ii) the fair market value of the property as a whole on the date of the gift, which is the denominator. For example, if the fair market value of an easement on the date of the gift was $\$ 300,000$, and the fair market value of the property as a whole on the date of the gift was $\$ 1,000,000$, the easement represented $30 \%$ of the value of the property on the date of the gift, and the holder must be entitled to at least $30 \%$ of the proceeds following the easement's extinguishment.

lost conservation or historic values) and (ii) eliminate the property owner's perverse incentive to seek extinguishment to benefit from any appreciation in the value of the easement following its donation, which may be significant. 
In Carroll, the conservation easement deed limited the numerator of the formula noted above to "the deduction for federal income tax purposes allowable" by reason of the donation. The court explained that, if the IRS were to disallow the deduction for reasons other than valuation and the easement were later extinguished in a judicial proceeding, the numerator would be zero and the holder of the easement would not receive the minimum proportionate share of proceeds as is required. The court also noted that deductions are denied for many reasons unrelated to valuation, and, in fact, the IRS made numerous arguments for disallowance of the taxpayers' claimed deductions in Carroll that were not based on valuation.

Although not mentioned by the court, mandating that the holder receive at least a minimum proportionate share of proceeds following extinguishment even if the donor's deduction is disallowed for other than valuation reasons is appropriate from a policy perspective. Donors of other types of charitable gifts are not entitled to a return of those gifts or the value attributable thereto if their deductions are denied for such things as failure to obtain a contemporaneous written acknowledgment or qualified appraisal. Moreover, regardless of whether a donor's deduction is denied, holders have an ongoing obligation to monitor and enforce the easements on behalf of the public and they must invest time and resources fulfilling that obligation. The value attributable to a conservation easement is a charitable asset held for the benefit of the public and it should not be permitted to revert to the donors (or the donors' successors in interest) upon extinguishment. Rather, such value should remain in the charitable sector and be used to replace lost conservation values, as Treasury Regulation $\S$ $1.170 \mathrm{~A}-14(\mathrm{~g})(6)$ requires.

The Tax Court distinguished its holding in Carroll from the First Circuit's holding in Kaufman III. In Kaufman III, the First Circuit held that the donors of a facade easement had satisfied the proceeds requirement because the easement deed correctly stated the proceeds formula and the donee organization had an absolute right as against the donors for its share of proceeds upon extinguishment. ${ }^{114}$ In Carroll, in contrast, the donee organizations would not be entitled to any proceeds in certain circumstances based on the formula included in the easement deed. Consistent with the First Circuit's reasoning in Kaufman III, failing to guarantee that the donees would be entitled to at least the required minimum proportionate share of proceeds upon extinguishment, and providing a potential windfall to the donor or the donor's successors as a result, was fatal to the deduction.

The Tax Court also dismissed the taxpayers' argument that noncompliance with the proceeds requirement should be forgiven because the probability of extinguishment of the easement was "so remote as to be negligible." Citing Kaufman III, the Tax Court explained that easement donors cannot

\footnotetext{
114 The Tax Court has declined to follow this holding in Palmolive I, as discussed in Part II.F.1 below.
} 
satisfy the requirements of the extinguishment regulation by merely establishing that the possibility of a change in conditions triggering judicial extinguishment is unexpected. To accept such an argument, explained the Tax Court, would nullify the requirements because the extinguishment regulation, by its terms, applies only to "unexpected" conditions. ${ }^{115}$

Finally, the Tax Court explained that the taxpayers in Carroll "could have avoided this adverse outcome by strictly following the proportionality formula set forth in the regulation." In addition, in finding that the taxpayers were liable for accuracy-related penalties, the court noted:

[The taxpayers] offered no evidence which would explain why the terms of the conservation easement varied from the requirements of [Treasury Regulation $\S 1.170 \mathrm{~A}-14(\mathrm{~g})(6)$ ], nor do they clarify why [they] failed to seek competent advice from a tax attorney or other adviser to ensure the conservation easement's compliance with pertinent regulations. In the light of [the taxpayers'] high level of sophistication and experience with conservation easements, we conclude that [the taxpayers] have not demonstrated that they acted with reasonable cause and in good faith in not seeking competent tax advice regarding the conservation easement.

There are a number of takeaways from Carroll. First, conservation easement donations generally involve high-dollar deductions and the requirements of $\S 170(\mathrm{~h})$ and the regulations are numerous. Accordingly, prospective easement donors should hire experienced tax counsel to assist them with their donations. If they do not, they run the risk of not only having their deductions denied, but also being subject to penalties. Too often easement donors are either unrepresented by legal counsel, or represented by legal counsel with little or no relevant tax expertise.

Second, donors of conservation easements should not rely on a donee organization, or donee's template, or any other template or model easement (many of which are out-of-date) to satisfy the requirements for the deduction. The risks of noncompliance (audit, litigation, denial of

\footnotetext{
115 The Tax Court further found that the donors' deductions were not saved by the last sentence in Treasury Regulation $\S 1.170 \mathrm{~A}-14(\mathrm{~g})(6)(\mathrm{ii})$, which provides an exception to the requirement that the holder must receive at least a minimum proportionate share of proceeds upon extinguishment if "state law provides that the donor is entitled to the full proceeds from the conversion without regard to the terms of the [easement]." Maryland has an unusual provision in its state code. Pursuant to this provision, if land subject to an easement held by Maryland Environmental Trust (MET) is condemned, damages must be awarded "to the fee owner...and shall be the fair market value of the land or interest in it, computed as though the easement...did not exist." This presumably means the holder would receive nothing unless the parties agreed that the fee owner would give a portion of the proceeds to the holder. The Carroll easement had been granted to MET and a local land trust as co-holders. The Tax Court held that the state code provision above did not save the deduction because (i) the provision applies only to easements held by MET and, thus, the proceeds formula in the deed still violated the proceeds requirement with regard to the local land trust, and (ii) the provision applies only to condemnations and, thus, the proceeds formula in the deed still violated the proceeds requirement with regard to judicial extinguishments not based on condemnation.
} 
deductions, and interest and penalties) fall on the shoulders of the donor, and it is the responsibility of the donor and the donor's tax counsel to ensure that all requirements are satisfied. Most donees are careful to instruct donors that they cannot and do not provide legal advice, and donors need to take that warning to heart.

b. PBBM-Rose Hill. In PBBM-Rose Hill II, the Fifth Circuit similarly sustained the IRS's disallowance of a $\$ 15,160,000$ deduction claimed with regard to a conservation easement donation because the easement contained a noncompliant proceeds clause. The proceeds clause included in the PBBM-Rose Hill easement provided that, following extinguishment, the holder was entitled to a share of the proceeds from a subsequent sale, exchange, or involuntary conversion of the property equal to the greater of (i) the fair market value of the easement around the date of the gift or (ii) a "defined share" of the amount of such proceeds remaining after both the expenses of the sale and the amount attributable to any improvements constructed upon the property pursuant to reserved rights was deducted. The defined share was the percentage determined by (i) the fair market value of the easement around the date of the gift over (ii) the fair market value of the property as a whole around the date of the gift (e.g., the $30 \%$ in the example provided in the discussion of Carroll above).

The Fifth Circuit held that this formula did not satisfy the proceeds requirement because the plain language of Treasury Regulation $\S 1.170 \mathrm{~A}$ 14(g)(6)(ii) does not permit the value of improvements to be subtracted from the proceeds prior to the holder taking its share. The court also held that an IRS Private Letter Ruling sanctioning a proceeds clause that provided for such subtraction was not relevant because (i) the Regulation is not ambiguous and (ii) even if the Regulation were ambiguous, the court would not defer to an IRS interpretation in a Private Letter Ruling because such a ruling is binding only with respect to the parties at issue and cannot be cited as precedent. ${ }^{116}$

It seems likely that, in crafting the proceeds requirement of Treasury Regulation $\S 1.170 \mathrm{~A}-14(\mathrm{~g})(6)(\mathrm{ii})$, the Treasury specifically chose to create a simple, bright-line rule that relies on the qualified appraisal of a conservation easement obtained at the time of its donation. The Treasury was aware of the issue of reserved rights, which are addressed elsewhere in the Treasury Regulations, and it presumably also was aware that a conservation easement might appreciate in value relative to the property it encumbers over time (development pressures were increasing in the 1980s when the Regulations were drafted). Yet the Treasury did not address those

\footnotetext{
${ }^{116}$ A Private Letter Ruling (PLR) is a written statement issued to a taxpayer that interprets and applies tax laws to the taxpayer's specific set of facts. A PLR may not be relied on as precedent by other taxpayers or IRS personnel. PLRs are generally made public after all information has been removed that could identify the taxpayer to whom it was issued. See IRS, Understanding IRS Guidance - A Brief Primer, available at http://www.irs.gov/uac/Understanding-IRS-GuidanceA-Brief-Primer.
} 
issues in $\S 1.170 \mathrm{~A}-14(\mathrm{~g})(6)(\mathrm{ii})$. The Treasury may have considered that any variation from the simple, bright-line rule to take into account the value of post-donation improvements or possible appreciation in the value of an easement would require that an additional appraisal be obtained at a later date, and a host of difficult issues would be raised by such a future appraisal. In addition to the property owner and holder having opposing interests with regard to such a future appraisal, a number of questions would arise: Would it have to be a "qualified appraisal"? Who would choose the appraiser? Who would define the scope of the assignment? What valuation methods should be employed (e.g., should improvements be valued using the before and after or replacement cost method)? Who would pay for the appraisal? What would be done if the owner and holder did not agree on the appraised value? The Treasury may have determined that the Regulation's simple, bright-line rule is, on balance, the better approach because it is based on the qualified appraisal already required to be obtained at the time of donation and avoids difficult future valuation issues.

In response to $P B B M$-Rose Hill, an easement donor that plans to construct valuable improvements on the encumbered property might be prompted to consider either (i) leaving designated building areas out of the conservation easement and therefore unrestricted or (ii) conveying two easements, one nondeductible easement encumbering the designated building areas, and a second deductible easement encumbering the remaining property that satisfies all federal tax law requirements. However, neither of these options is ideal. The first — leaving building areas entirely unrestricted — could have a detrimental effect on the protection of the conservation values of the encumbered land and reduce the donor's deduction as a result of the "entire contiguous parcel" valuation rule. ${ }^{117}$ The second-conveyance of two easements - would increase the expense and complexity of the donation transaction. The costs associated with these options also may be disproportionate to the potential benefits obtained for a number of reasons.

- First, the Treasury Regulation's formula, which requires the payment of only a fixed minimum percentage of proceeds to the holder following extinguishment, will benefit the property owner if the value of the easement relative to the value of the land increases following the date of the donation, which may often be the case.

- Second, extinguishments, which require a judicial proceeding and a finding of impossibility or impracticality, should be extremely rare, occurring only in "extraordinary circumstances" (see Belk III, Carpenter).

- Third, the likelihood of an extinguishment during the donor's limited ownership period is even more remote.

- And fourth, while condemnation is a possibility, condemnations are also relatively rare, and condemning authorities generally go out of

${ }^{117}$ See Part II.A.8 above, discussing options for addressing reserved development rights. 
their way to avoid condemning structures, particularly personal residences.

Thus, while for some donors the costs associated with the two options noted above may be worth the potential benefits, for many donors, given that extinguishment of a perpetual easement is extremely unlikely, encumbering the entire property (including the building areas) with a single easement and including a compliant proceeds clause that does not subtract the value of improvements will be the best option.

13. Noncompliant Deemed Approval Clause. In a July 12, 2017, pre-trail Order issued in Hoffman Properties II, LP v. Comm'r (Docket No. 14130-15), ${ }^{118}$ the Tax Court determined that the Hoffman partnership was not entitled to a $\$ 15$ million deduction for the donation of a façade easement on a building because the easement contained an "automatic approval" clause. Specifically, the easement reserved to Hoffman the right to modify, alter, or expand the building and its exterior in any manner desired, provided that Hoffman obtained prior approval from the holder. The easement further provided that if the holder failed to expressly reject a request for approval within 45 days of receiving it, the request was automatically approved and Hoffman could proceed with the proposed activity - even if the activity were inconsistent with the historic character of the exterior and the conservation purposes of the easement. The court explained that the automatic approval clause stripped the holder of any right to object to or remedy alterations or modifications that might be inconsistent with the historic character of the exterior or otherwise jeopardize the easement's conservation purpose. As a result, the conservation purpose of the easement was not protected in perpetuity and the easement failed to qualify for a deduction under $\S 170(\mathrm{~h})$.

In a March 14, 2018, Order, the court denied Hoffman's motion to reconsider its holdings in its July 2017 Order and affirmed those holdings. The court also addressed Hoffman's argument that the shortcomings in the easement were irrelevant because the general public or the Ohio Attorney General (AG) had the right to prevent Hoffman from altering or modifying the building's façade in a manner inconsistent with the building's historic character. In support of this argument, Hoffman cited to Ohio statutory and case law empowering the AG to enforce, oversee, and administer charitable interests and nonprofit corporations. In rejecting this argument, the court explained that, while it is undisputed that Ohio law empowers the AG to initiate a suit to enforce the terms of an easement if the holder neglects to do so, the AG does not possess any greater rights than those granted to the holder under the easement. Thus, neither the holder nor the AG could object to an activity undertaken by Hoffman that had been automatically approved under the automatic approval clause.

Finally, in a second March 14, 2018, Order, in which the court came to similar conclusions regarding the portion of the easement relating the air space above the building, Hoffman argued that the possibility that the holder would fail to deny a

118 Tax Court Orders are available on the Tax Court website: https://www.ustaxcourt.gov. 
request to do something inconsistent with the purpose of the easement within the 45-day period was "so remote as to be negligible." In rejecting this argument, the court explained that inclusion of the automatic approval clause in the easement indicated that the parties did not consider that possibility to be improbable (i.e., so remote as to be negligible).

Although not mentioned by the court, denying a deduction for a conservation easement containing an automatic approval clause is also appropriate from a policy perspective. A tax-deductible conservation easement should not be rendered unenforceable as a result of the holder's inaction. A holder may fail to respond to a request from the landowner for a variety of reasons, such as other pressing obligations, misplaced mail, email oversight, turnover in staff, or gross negligence, none of which should result in the forfeiture of the public's rights and investment in an easement. ${ }^{119}$

Although Tax Court Orders are of limited precedential value, ${ }^{120}$ the Hoffman Orders signal the position of the Tax Court and the IRS with regard to automatic approval clauses. Sometimes attorneys representing property owners treat conservation easement donations as if they are commercial transactions rather than charitable contributions, and these attorneys negotiate to include clauses in the easement deed that they think will benefit the property owner, such as an automatic approval clause. These attorneys fail to recognize that they are dealing with a charitable contribution intended to provide perpetual benefits to the public and, to be eligible for a deduction, the conservation purpose of the easement must be protected in perpetuity. The Hoffman Orders should make clear that such clauses are not appropriate in the tax-deductible conservation easement context.

Rather than automatic approval, a holder's failure to respond should be deemed a constructive denial. Below is a sample "constructive denial" clause. ${ }^{121}$

For activities or uses that are expressly permitted by the terms of this Easement only with Holder's approval, Owner's request for approval shall be in writing and shall describe the nature, scope, design, location, timetable, and any other material aspect of the proposed activity or use in sufficient detail to permit Holder to make an informed determination regarding approval or denial of the request. Such a request shall be delivered to Holder at least sixty (60) days prior to the anticipated start date of such activity or use. Holder agrees to use reasonable diligence to respond to the request within sixty (60) days of delivery. Holder's failure to respond to

\footnotetext{
${ }^{119}$ For cases in which the court held that the public's rights with respect to a conservation easement were not forfeited as a result of the actions or inactions of the holder, see, e.g., Feduniak v. California Coastal Commission, 148 Cal. App. 4th 1346 (2007); Weston Forest and Trail Assoc. v. Fishman, 849 N.E. 2d 916 (Mass. App. Ct. 2006).

${ }^{120}$ U.S. Tax Court Rules of Practice and Procedure, Rule 50(f) ("Orders shall not be treated as precedent, except as may be relevant for purposes of establishing the law of the case, res judicata, collateral estoppel, or other similar doctrine.").

${ }^{121}$ This sample provision is drafted to comply with $\S 170(\mathrm{~h})$ and Treasury Regulation requirements. However, neither the IRS nor the courts have blessed this sample provision. Readers are responsible for obtaining legal advice from their own legal counsel.
} 
such a request within the sixty (60) day period shall be deemed a constructive denial. Because a constructive denial is not a decision by Holder based on the merits of Owner's request, it is not final or binding on Holder, and Owner can resubmit the same or a similar request for approval.

This clause protects the public because the easement will not be rendered unenforceable due to the holder's failure to respond within the specified time period. This clause also protects the property owner from an unreasonable or negligent holder because the property owner can seek redress in the courts if the holder fails to use "reasonable diligence" to respond within the designated time period.

14. Releasing Land With Transfer to "Comparable" Easement. In Salt Point Timber, the Tax Court sustained the IRS's disallowance of a \$2.1 million deduction claimed by an LLC for the donation of a conservation easement on a 1,032-acre parcel in South Carolina. The conservation easement contained a "boundary line adjustment" provision that required the holder to release land from the original easement (an extinguishment of the original easement with regard to the released land) if (i) the released land was transferred to the owner of adjacent property encumbered by a "comparable" conservation easement and (ii) the owner of the adjacent property and the holder of the comparable easement agreed to modify the comparable easement to add the released land.

The Tax Court denied the deduction because the boundary line adjustment provision did not require the holder of the "replacement" (comparable) easement to be a "qualified organization" within the meaning of $\S 170(\mathrm{~h})$. The court explained that, had the parties intended the replacement easement to be held by a qualified organization, they could have easily written such a restriction into the boundary line adjustment provision, which they did not do. In addition, the expectation that the word "comparable," which was not defined in the easement, incorporated such a specific requirement was not objectively reasonable.

The Tax Court also determined that the possibility that acreage would be released from the original easement and encumbered by a replacement easement was not "so remote as to be negligible." There was an expectation that the donation of the original easement would "encourage neighboring landowners to commit their properties to conservation in a domino-effect fashion," state and local entities were encouraging and subsidizing the donation of conservation easements in the area, and, significantly, the parties had "bothered to put" the boundary line adjustment provision in the easement.

Because the Tax Court denied the deduction on the grounds noted above, it did not address the IRS's argument that the boundary line adjustment provision permitted the restrictions of the original easement to be extinguished with regard to the released land without satisfaction of the Treasury Regulations' judicial extinguishment requirements. 
15. Reimbursement of Funders on Extinguishment. Irby analyzed Treasury Regulation $\S 1.170 \mathrm{~A}-14(\mathrm{~g})(6)(\mathrm{ii})$ (the division of proceeds portion of the extinguishment regulation) as applied to conservation easements conveyed in bargain sale transactions. The conservation easements in Irby had been conveyed to a land trust, but three government entities had supplied funding to pay approximately $75 \%$ of the value of the easements to the landowners, and the landowners made charitable gifts of the remaining $25 \%$. To be eligible for a deduction for the donation component of a bargain sale transaction, the donation must meet all of the statutory and regulatory requirements for the deduction. ${ }^{122}$

The easement deeds in Irby provide that the grantee (the land trust) is entitled to Treasury Regulation $\S 1.170 \mathrm{~A}-14(\mathrm{~g})(6)(\mathrm{ii})$ 's mandated minimum proportionate share of proceeds following extinguishment, but must pay $75 \%$ of those proceeds to the government entities to reimburse them for their contributions to the purchase price of the easements, which would leave the grantee with only $25 \%$ of the proceeds.

a. The IRS argued that the reimbursement obligation meant that the grantee was not actually entitled to the mandated minimum proportionate share of proceeds following extinguishment-i.e., that its entitlement was merely "superficial." The Tax Court disagreed. The court explained that, unlike the situation where a lender holding an outstanding mortgage on the property is given priority to proceeds upon extinguishment (which furthers the taxpayer's interests because the proceeds will be used to pay down the taxpayer's debt), there was no risk that the taxpayers in Irby could reap a similar windfall upon extinguishment because the proceeds payable by the grantee to the governmental entities, each of which has a conservation mission, would be used by such entities "in a manner consistent with the original conservation purposes of the contribution" (as explained in the next paragraph). Thus, the court found that the easement deeds met the requirements of division of proceeds regulation.

b. The Tax Court noted that the IRS's concerns in Irby more properly seemed to address the question of whether all of the extinguishment proceeds would be used by the grantee "in a manner consistent with the conservation purposes of the original contribution" as required by Treasury Regulation $\S 1.170 \mathrm{~A}-14(\mathrm{~g})(6)(\mathrm{i})$. The court determined that they would. It explained that all three government entities "were established to assist the conservation of open land" and are "legally obligated to fulfill their conservation purpose." In addition, the court stated that it appeared that the reimbursements would enhance the ability of the government entities "to conserve and protect more land, since the reimbursed funds would be used to do just that." Accordingly, the court found that the reimbursement

${ }^{122}$ See IRS Conservation Easement Audit Techniques Guide, supra note 23, at 39 and 40. 
provision in Irby did not violate the requirements of either the extinguishment or division of proceeds regulations. ${ }^{123}$

c. The Tax Court issued stipulated decisions in Irby in December 2013 ordering the taxpayers to pay agreed upon deficiencies in income tax for taxable years 2003 and 2004, but no penalties were imposed.

16. Safe Harbor Provisions and Amnesty Period. The amount of litigation in this context could be significantly reduced if the IRS developed safe harbor or "sample" conservation easement provisions to satisfy the key perpetuity requirements of $\S$ 170(h). While many provisions of an easement must be tailored to the specific property and situation, many of the perpetuity requirements, including those addressing restriction on transfer, judicial extinguishment, and division of proceeds upon extinguishment, could be satisfied with provisions that generally should not vary from easement to easement. Safe harbor provisions would facilitate both donor compliance and IRS review, and would help to ensure that the public investment in easements and their conservation purposes is actually "protected in perpetuity" as Congress intended. Moreover, developing safe harbor provisions would not be a novel approach to facilitating compliance and curbing abuse. The Treasury developed safe harbor trust provisions with annotations in the charitable remainder trust and charitable lead trust contexts and those provisions, which are widely used, have greatly facilitated compliance and reduced abuses.

The IRS and Treasury also could consider providing a temporary amnesty period upon issuance of safe harbor provisions. That is, give taxpayers a period of time (e.g., 6 months) to amend already recorded easement deeds to bring noncompliant clauses into compliance and, if they do, the fact that the deeds contained those noncompliant clauses at the time of their donation would not result in a denial of the deduction. But if taxpayers do not amend their deeds to come into compliance during the amnesty period, the donations could be challenged on those grounds.

\section{B. IRS Form 8283 (Appraisal Summary)}

\section{History.}

a. In 1984, as part of the Deficit Reduction Act of 1984 (DEFRA), ${ }^{124}$ Congress required taxpayers claiming deductions for noncash charitable contributions in excess of $\$ 5,000$ to obtain a qualified appraisal prepared by a qualified appraiser and attach an appraisal summary to the return on which

\footnotetext{
${ }^{123}$ Some have argued that the court reached the correct result in Irby, but for the wrong reason. Treasury Regulation $\S$ $1.170 \mathrm{~A}-14(\mathrm{~g})(6)$ (ii) could be viewed as applying only to the portion of the proceeds attributable to the contribution component of a bargain sale transaction, and not to the portion of the proceeds attributable to the sales component of the transaction. Allowing the funders to be reimbursed for the funds they contributed to the purchase price should thus not run afoul of the proceeds requirement, although the priority of the payments might be an issue.

124 Pub. L. No. 98-369, 98 Stat. 691 (1984).
} 
the deduction is first claimed for the property contributed. ${ }^{125}$ DEFRA also directed the Secretary of the Treasury to prescribe regulations implementing the statutory requirements. Pursuant to this legislative mandate, the IRS and the Treasury Department promulgated Treasury Regulation $\S 1.170 \mathrm{~A}-13$ (c), which provides that no deduction shall be allowed for a noncash contribution in excess of $\$ 5,000$ unless the taxpayer:

(i) obtains a qualified appraisal prepared by a qualified appraiser, and

(ii) attaches a fully completed appraisal summary (IRS Form 8283) to the tax return on which the taxpayer first claims a deduction for the contribution.

b. In 2004, Congress added $\S 170(f)(11)$ to the Internal Revenue Code effective for contributions made after June 3, 2004. ${ }^{126}$ Section 170(f)(11) provides, among other things, that:

(i) in the case of contributions of property for which a deduction of more than $\$ 5,000$ is claimed, the taxpayer must obtain a qualified appraisal and attach to the return for the taxable year in which such contribution is made such information regarding such property and such appraisal as the Secretary may require, ${ }^{127}$ and

(ii) in the case of contributions of property for which a deduction of more than $\$ 500,000$ is claimed, the taxpayer must attach the full qualified appraisal to the return (i.e., the entire qualified appraisal must be filed with the Form 8283). ${ }^{128}$

c. In 2006, Congress amended $\S 170(f)(11)$ to add statutory definitions of the terms "qualified appraiser" and "qualified appraisal" $(\S 170(\mathrm{f})(11)$, as amended, is attached as Appendix D). ${ }^{129}$

d. Later in 2006, the IRS issued Notice 2006-96, which, among other things, provided transitional guidance regarding $\S 170(f)(11)(E)$ 's definitions of qualified appraisal and qualified appraiser.

\footnotetext{
${ }^{125}$ DEFRA $\S 155(a)$. Congress defined the term "qualified appraisal" to mean an appraisal prepared by a qualified appraiser that includes, among other information: (1) a description of the property appraised, (2) the fair market value of the property on the contribution date and the specific basis for valuation, (3) a statement that the appraisal was prepared for income tax purposes, (4) the qualifications of the appraiser, and (5) any additional information the Secretary may prescribe by regulation. DEFRA $\S 155(a)(4)$.

${ }^{126}$ See $\S 883$ of the American Jobs Creation Act of 2004, Pub. L. No. 108-357, 118 Stat. 1418.

127 IRC $§ 170(f)(11)(C)$.

${ }^{128}$ IRC $\S 170(f)(11)(D)$.

${ }^{129}$ IRC $\S 170(f)(11)(E)$. See $\S 1219$ of the Pension Protection Act of 2006, Pub. L. No. 109-280, 120 Stat. 780 . For an explanation of the Pension Protection Act of 2006 changes, see JCT Explanation of Pension Protection Act of 2006, supra note 17.
} 
e. In 2008, the Treasury Department issued proposed regulations implementing the substantiation and reporting requirements for charitable contribution deductions. ${ }^{130}$ Until these regulations were finalized and effective, the transitional guidance in IRS Notice 2006-96 applied.

f. In July 2018, the Treasury Department issued final regulations implementing substantiation and reporting requirements for charitable contribution deductions (attached as Appendix E). ${ }^{131}$

(i) Treasury Regulation $\S 1.170 \mathrm{~A}-16$ sets forth the substantiation and reporting requirements for noncash charitable contributions made after July 30, 2018, although taxpayers may rely on the rules of this regulation for contributions made after June 3, 2004, or appraisals prepared for returns or submissions filed after August 17, 2006. ${ }^{132}$ Pursuant to this regulation:

(1) No deduction is allowed for a noncash charitable contribution of more than $\$ 5,000$ unless the donor:

- substantiates the contribution with a contemporaneous written acknowledgment from the donee,

- obtains a qualified appraisal prepared by a qualified appraiser, and

- completes Form 8283 (Section B) and files it with the return on which the deduction is claimed. ${ }^{133}$

(2) For a noncash charitable contributions of more than $\$ 500,000$, the donor must also attach a copy of the qualified appraisal to the return on which the deduction is claimed. ${ }^{134}$

(3) These requirements also apply to a return filed for any carryover year. ${ }^{135}$

(ii) Treasury Regulation $\S 1.170 \mathrm{~A}-17$ sets forth the requirements for "qualified appraisals" and "qualified appraisers" for contributions made on or after January 1, 2019, although taxpayers may rely on the rules of this regulation for appraisals prepared for returns or submissions filed after August 17, 2006. ${ }^{136}$

\footnotetext{
${ }^{130}$ See Substantiation and Reporting Requirements for Cash and Noncash Charitable Contribution Deductions, 73 Federal Register 45908 (proposed August 7, 2008).

131 TD 9836, Final Regulations, Substantiation and Reporting Requirements for Cash and Noncash Charitable Contribution Deductions (July 30. 2018) [hereinafter Final Substantiation and Reporting Regulations] (attached at Appendix E).

${ }^{132}$ Treas. Reg. $\S 1.170 \mathrm{~A}-16(\mathrm{~g})$.

${ }^{133}$ Treas. Reg. § 1.170A-16(d)(1).

134 Treas. Reg. $\S 1.170 \mathrm{~A}-16(\mathrm{e})(1)$

135 Treas. Reg. $\$ 1.170 \mathrm{~A}-16(\mathrm{f})(3)$.

136 Treas. Reg. $\S 1.170 \mathrm{~A}-17(\mathrm{c})$.
} 
(iii) Treasury Regulation $\S 1.6050 \mathrm{~L}-1(\mathrm{~d})(2)$ provides that a donee must retain the Form 8283 "for so long as it may be relevant in the administration of any internal revenue law."

g. As the foregoing indicates, the qualified appraisal, qualified appraiser, and appraisal summary requirements are both statutory and regulatory requirements.

2. IRS Form 8283, Section B. Donors should correctly and completely fill out Section B of IRS Form 8283 and attach a Supplemental Statement as described below. Donors should not rely on substantial compliance.

a. DEFRA specifically requires taxpayers to include on the return on which a deduction is first claimed such information as may be prescribed by Treasury Regulations, including the cost basis and acquisition date of the donated property. ${ }^{137}$ The Treasury Regulations implement this requirement by providing that the appraisal summary (Form 8283) must include, among other things: (i) the fair market value of the property on the "valuation effective date"; (ii) the manner and approximate date of acquisition of the property by the donor; (ii) the cost or other basis of the property; and (iv) a statement explaining whether the contribution was made by means of a bargain sale and, if so, the amount of any consideration received. ${ }^{138}$

b. The donee and the individual appraiser or appraisers (if more than one) must all sign the Form 8283. ${ }^{139}$

c. The Instructions for Form 8283 state, with regard to Section B, Part I, Line 5, Columns (d)-(f) (addressing date acquired, how acquired, and basis): "If you have reasonable cause for not providing the information in columns (d), (e), or (f), attach an explanation so your deduction will not automatically be disallowed" (emphasis added). The Instructions also provide: "For a qualified conservation contribution, indicate whether you are providing information about the underlying property or about the easement."

d. The case law in this context is unpredictable. For example, in Kaufman III, the First Circuit held that the taxpayers' failure to include the date, manner of acquisition, and cost or other basis relating to a façade easement on the Form 8283 was not fatal to the deduction. ${ }^{140}$ However, in Belair, the Tax Court held that the taxpayer, who on the advice of a consultant had declined to include the cost basis relating to a conservation easement on the Form 8283, neither strictly nor substantially complied with the Treasury

\footnotetext{
${ }^{137}$ DEFRA $\S 155(\mathrm{a})(1)(\mathrm{C})$.

${ }^{138}$ See Treas. Reg. § 1.170A-16(d)(3).

${ }^{139}$ See Treas. Reg. § 1.170A-16(d)(3), (4), (5), (7).

140 See also Scheidelman III.
} 
Regulation requirements. The taxpayer in Belair claimed a deduction for the donation that presupposed that the encumbered land had increased in value by $1,380 \%$ in the $2 \frac{1}{2}$ years since its purchase, amid the worst real estate crisis since the Great Depression. The court explained:

When a taxpayer claims a charitable contribution deduction for recently purchased property, a wide gap between cost basis and claimed value raises a red flag suggesting that the return merits examination. Unless the taxpayer complies with the regulatory requirement that he disclose his cost basis and the date and manner of acquiring the property, the Commissioner will be deprived of an essential tool that Congress intended him to have.

In response to the taxpayer's claim that it effectively disclosed its cost basis elsewhere on its tax return, the court noted:

The IRS reviews millions of returns each year for audit potential, and the disclosure of cost basis on the Form 8283 itself is necessary to make this process manageable. Revenue agents cannot be required to sift through dozens or hundreds of pages of complex returns looking for clues about what the taxpayer's cost basis might be.... If cost basis is not explicitly disclosed where it is required to be disclosed, the Commissioner will be handicapped in identifying suspicious charitable deductions and deterring taxpayers from "continu[ing] to play the 'audit lottery.'

Moreover, Belair was not a case were the taxpayer had omitted the information through inadvertence. Rather, the taxpayer made a conscious election not to supply the required information. However, the Tax Court determined that it did not have sufficient facts to resolve the issue of whether the taxpayer could qualify for the reasonable cause defense. ${ }^{141}$

e. The IRS Conservation Easement Audit Techniques Guide provides the following list of common errors in Section B of Form 8283:

- Inadequate description of the property

- Missing information

- Missing signatures

- Inconsistent dates ${ }^{142}$

3. Supplemental Statement. The Instructions for Form 8283 require the donor to attach a supplemental statement to the form.

a. The supplemental statement must:

\footnotetext{
${ }^{141}$ See $\S 170(\mathrm{f})(11)(\mathrm{A})(\mathrm{ii})(\mathrm{II})$.

${ }^{142}$ See IRS Conservation Easement Audit Techniques Guide, supra note 23, at 27.
} 
(i) identify the conservation purposes furthered by the donation,

(ii) show, if before and after valuation is used, the fair market value of the underlying property before and after the gift,

(iii) state whether the donation was made in order to get a permit or other approval from a local or other governing authority and whether the donation was required by a contract (i.e., was there a quid pro $q u o)$, and

(iv) if the donor or a related person has any interest in other property nearby, describe that interest.

b. The Supplemental Statement should be comprehensive and detailed (numerous pages long). An example of a supplemental statement is attached as Appendix F.

4. Special Rules for Facade Easement Donations. For the donation of a façade easement on a building in a registered historic district, in addition to the Form 8283 and Supplemental Statement, the taxpayer must include with the taxpayer's return for the year of the contribution: (a) a qualified appraisal, (b) photos of the entire exterior of the building, (c) a description of all restrictions on the development of the building, and (d) if the deduction claimed is more than $\$ 10,000$, a $\$ 500$ filing fee. ${ }^{143}$

In Gemperle, the Tax Court sustained the IRS's disallowance of deductions claimed with regard to the donation of a façade easement because the taxpayers, a married couple who represented themselves in Tax Court, failed to include a qualified appraisal of the easement with the return they filed for the year of the contribution. The court also found the Gemperles liable for $20 \%$ penalties for "disregard of rules or regulations" under IRC $\S 6662(a)$ and (b)(1). The court explained that the requirement that the full qualified appraisal be included with the tax return filed for the year of the contribution is stated not only in the Internal Revenue Code but also in the instructions for the Form 8283, and the taxpayers "were at least careless, if not reckless, in ignoring the warning that an appraisal was required." The court further found that the Gemperles were alternatively liable for $40 \%$ strict liability penalties under IRC $\S 6662(\mathrm{~h})$ for making gross valuation misstatements on their 2007 and 2008 returns with regard to the easement.

\section{Qualified Appraisal Requirements}

1. General Requirements. The current "qualified appraisal" requirements are found in IRC $\S 170(\mathrm{f})(11)$ (attached as Appendix D) and Treasury Regulation $\S$ 1.170A-17 (attached as Appendix E). Treasury Regulation $\S 1.170 \mathrm{~A}-17$ applies to contributions made on or after January 1, 2019, although taxpayers may rely on the

\footnotetext{
${ }^{143}$ See IRC $\S \S 170(\mathrm{~h})(4)(B)(i i i)$ and 170(f)(13). See also IRS Form 8283-V.
} 
rules of this regulation for appraisals prepared for returns or submissions filed after August 17, 2006. ${ }^{144}$

For the "qualified appraisal" regulations in effect before Treasury Regulation $\S$ 1.170A-17, see Treasury Regulation $\S 1.170 \mathrm{~A}-13$. For transitional guidance regarding $\S 170(f)(11)(E)$ 's definitions of "qualified appraisal" and "qualified appraiser," see IRS Notice 2006-96. Taxpayers may rely on Notice 2006-96 prior to the effective date of Treasury Regulation $\S 1.170 \mathrm{~A}-17$, noted above. ${ }^{145}$ For a history of these requirements, see Part II.B.1 above.

Because Treasury Regulation $\S 1.170 \mathrm{~A}-17$ incorporates or only slightly modifies many of the qualified appraisal and qualified appraiser requirements in place before its effective date, the cases below, which were decided based on the former requirements, remain relevant.

a. Donors Should Strictly Comply. Donors should strictly comply with all statutory and regulatory qualified appraisal requirements. While in some cases the courts have been willing to forgive failures to strictly comply with some of the requirements, ${ }^{146}$ in the following cases failures to strictly comply led to a complete disallowance of the claimed deductions.

(i) Lord. In Lord, the Tax Court sustained the disallowance of a deduction for the donation of a conservation easement because the taxpayer's appraisal (which did not include the easement contribution date, the date the appraisal was performed, or the appraised fair market value of the easement on the contribution date) was not a qualified appraisal. The doctrine of substantial compliance was not applicable because significant information was omitted.

(ii) Costello. In Costello, landowners conveyed a conservation easement permanently prohibiting development of their 73-acre farm to Howard County, Maryland, in exchange for the right to sell 16 development rights to a developer for $\$ 2.5$ million. The developer was able to use those rights to increase density on parcels located in a "receiving area" of the county (i.e., the exchange was pursuant to the county's transfer of development rights program). Seven months later, the landowners hired an appraiser to appraise

\footnotetext{
144 Treas. Reg. $\S 1.170 \mathrm{~A}-17(\mathrm{c})$.

${ }^{145}$ See Final Substantiation and Reporting Regulations, supra note 131, at 36418.

${ }^{146}$ In Zarlengo, the Tax Court held that the taxpayer complied or substantially complied with the various qualified appraisal requirements even though, among other things, the appraisal was "premature" (i.e., prepared more than sixty days prior to the date of the contribution). In Irby, the Tax Court held that an appraisal report's discussion of the purpose of the appraisal (i.e., to value an easement for purposes of $\S 170(\mathrm{~h})$ ) was sufficient to satisfy Treasury Regulation $\S$ $1.170 \mathrm{~A}-13(\mathrm{c})(3)(\mathrm{ii})(\mathrm{G})$ 's requirement that the appraisal contain "[a] statement that the appraisal was prepared for income tax purposes." In Simmons II, Scheidelman II, and Friedberg II, the courts held that the appraisals obtained to substantiate façade easement donations sufficiently detailed the method used and basis of valuation for purposes of Treasury Regulation $\S 1.170 \mathrm{~A}-13(\mathrm{c})(3)(\mathrm{ii})(\mathrm{J})$ and $(\mathrm{K})$. Provision of the basis of valuation is also required by DEFRA $\S 155(a)(4)(B)$.
} 
their property before and after a "hypothetical" sale of development rights. The appraiser was unaware of the existing conservation easement and assumed the property could be developed into a 25lot subdivision. He estimated the value of the hypothetical development rights to be $\$ 5.5$ million and the taxpayers filed a tax return claiming a charitable income tax deduction of that amount. Howard county refused to sign an IRS Form 8283 as the "donee" because it questioned whether the conveyance of the easement constituted a charitable donation.

The IRS disallowed the claimed deduction on a number of grounds, including that the taxpayers failed to obtain a "qualified appraisal." The Tax Court sustained the disallowance, finding, among other things, that the taxpayer's appraisal failed to include the following three elements required for a qualified appraisal: (a) the appraisal did not contain an accurate description of the contributed property (the appraiser didn't describe or purport to value the conservation easement because the appraiser was unaware of its existence), (b) the appraisal did not contain the date of the contribution (unsurprising given that the appraiser was unaware of the easement conveyance), and (c) the appraisal did not contain the salient terms of any of the agreements relating to the contributed property (again, unsurprising given that the appraiser was unaware that the landowners had agreed to grant the easement to the county in exchange for the right to sell development rights for $\$ 2.5$ million).

After filing their initial income tax return and claiming a $\$ 5.5$ million deduction, the landowners apparently had second thoughts. They had their appraiser prepare an addendum to his appraisal that took into account their sale of development rights to the developer for $\$ 2.5$ million, and they filed an amended income tax return claiming a deduction of only $\$ 3$ million. However, the appraiser's addendum was not prepared within the required time period for the qualified appraisal (i.e., no more than 60 days before the date of the gift and no later than the due date (including extensions) of the return on which the deduction was first claimed). ${ }^{147}$ The Tax Court held that the untimely addendum did not convert the original appraisal into a qualified appraisal. The court also held that the appraisal did not "substantially comply" with the reporting requirements because it omitted numerous categories of important information and appraised the wrong asset.

The Tax Court further explained that, pursuant to IRC $\S 170(\mathrm{f})(11)(\mathrm{A})(\mathrm{ii})(\mathrm{II})$ (see Appendix D), "[e]ven absent strict or substantial compliance with the 'qualified appraisal' and reporting

${ }^{147}$ See Treas. Reg. § 1.170A-13(c)(3)(i)(A). 
requirements, a deduction will not be denied if the failure to meet those requirements is due to 'reasonable cause and not to willful neglect." The burden of proving reasonable cause is on the taxpayer, however, and the court held that, given the magnitude of the omissions from the appraisal and the Form 8283, particularly the failure to disclose the prior sale of development rights for $\$ 2.5$ million, the taxpayers could not show that their failures were due to reasonable cause.

(iii) Mecox. In Mecox, the U.S. District Court for the Southern District of New York sustained the IRS's complete disallowance of a deduction claimed with regard to the donation of a façade easement because (i) the easement was found not to have been contributed until the year it was recorded, which was the year following the year in which the taxpayer claimed the deduction and (ii) the appraisal was untimely (i.e., the appraisal was made more than 60 days prior to the date of the contribution ${ }^{148}$ ). For a more detailed discussion of Mecox, see Part III.C.2 below.

b. Collective Defects. After the Second Circuit's holding in Scheidelman II (discussed below), the Tax Court in Rothman II reconsidered its earlier opinion and concluded that the Rothman appraisal met the method used and basis of valuation requirements of the Treasury Regulations. However, the court noted that Treasury Regulation $\S 1.170 \mathrm{~A}-13$ imposed fifteen distinct requirements and the appraisal in Rothman failed to satisfy eight of the fifteen requirements. Because of the "collective defects," the court reconfirmed its holding that the appraisal was not qualified. The court further noted that, because the qualified appraisal regulation was promulgated under an express delegation of congressional authority and has been found to be valid, the U.S. Supreme Court instructs that courts respect the lines the Secretary of the Treasury has drawn therein as a valid exercise of rulemaking authority. Whether the donor in Rothman qualified for the "reasonable cause" exception for not having a qualified appraisal under $\S$ $170(\mathrm{f})(11)(\mathrm{A})(\mathrm{ii})(\mathrm{II})$ was an issue that remained to be tried, but the case settled.

c. Qualified Appraisals That Are Not Credible. In a number of façade easement cases the courts held that the appraisals met the minimal requirements of a qualified appraisal but did not provide credible evidence of value.

(i) Scheidelman. In Scheidelman II, the Second Circuit explained:

[f]or the purpose of gauging compliance with the reporting requirement, it is irrelevant that the IRS believes the method

${ }^{148}$ See Treas. Reg. $§ 1.170 \mathrm{~A}-13(\mathrm{c})(3)(\mathrm{i})(\mathrm{A})$. 
employed [a mechanical application of a percentage diminution] was sloppy or inaccurate, or haphazardly applied - it remains a method, and [the appraiser] described it. The regulation requires only that the appraiser identify the valuation method "used"; it does not require that the method adopted be reliable.

However, the Second Circuit went on to explain that its conclusion that the appraisal met the minimal requirements of a qualified appraisal mandated neither that the Tax Court find the appraisal persuasive nor that Scheidelman be entitled to any deduction for the donated façade easement, and it remanded to the Tax Court.

In Scheidelman III, the Tax Court held that, although the taxpayers' appraisal was a qualified appraisal: (a) the taxpayers did not provide sufficient credible evidence to meet their burden of establishing entitlement to the claimed deduction and (b) the preponderance of the evidence supported the IRS's position that the façade easement had no value.

In Scheidelman IV the Second Circuit affirmed the Tax Court's holding that the easement had no value. ${ }^{149}$ In support of its holding, the Second Circuit quoted the IRS's valuation expert, who explained that "in highly desirable, sophisticated home markets like historic brownstone Brooklyn, the imposition of an easement, such as the one granted...does not materially affect the value of the subject property." The Second Circuit also found persuasive the fact that the donee had assured one of Scheidelman's mortgagors that:

[a]s a practical matter, the easement does not add any new restrictions on the use of the property because the historic preservation laws of the City of New York already require a specific historic review of any proposed changes to the exterior of this property.

\footnotetext{
${ }^{149}$ In Evans, Dunlap, Foster, Scheidelman, Kaufman, Chandler, and Reisner, façade easements on residential properties were found to have no value (in Reisner the parties so stipulated). However, in some cases courts have determined that façade easements reduced the value of the properties they encumbered, albeit by less than the taxpayers' claimed. In Simmons I, Zarlengo, and Gorra, the Tax Court held that façade easements reduced the value of the subject residential properties by $5 \%, 3.5 \%$, and $\%$, respectively. In Seventeen Seventy Sherman Street, the IRS argued that a façade easement had no effect on the value of a historic shrine because of already existing local historic preservation restrictions. The Tax Court disagreed, holding that the easement was more protective of the shrine than local law. In Whitehouse Hotel, after two appeals, the Fifth Circuit affirmed the Tax Court's holding that a façade easement encumbering the historic Maison Blanche building (which is located in the French Quarter in New Orleans and is now used as a Ritz Carlton hotel) reduced the value of the building by $14.9 \%$. For a comprehensive discussion of the valuation case law through 2015, see Nancy A. McLaughlin, Conservation Easements and the Valuation Conundrum, 19 FLA. TAX REV. 225 (2016), available at http://papers.ssrn.com/sol3/papers.cfm?abstract id=2704576.
} 
(ii) Kaufman. In Kaufman III, the First Circuit vacated the Tax Court's opinions in Kaufman I and Kaufman II in part and remanded to the Tax Court on the issue of valuation. ${ }^{150}$ The First Circuit noted that the Kaufmans had expressed concern to the donee, the National Architectural Trust (NAT), about the high appraised value of the façade easement they were donating because it implied a substantial reduction in the resale value of their home, which was located in Boston's South End Historic District. "In an effort to reassure them, a [NAT] representative told the Kaufmans that experience showed that such easements did not reduce resale value." "This," said the First Circuit, "could easily be the IRS's opening argument in a valuation trial." 151 And so it apparently was.

In Kaufman $I V$, on remand from the First Circuit, the Tax Court sustained the IRS's complete disallowance of the deductions claimed with regard to the façade easement donation on the ground that the easement had no value. Although the Tax Court assumed the Kaufman's appraisal was a "qualified appraisal," the court gave no weight to the appraisal's estimate of value because it found the appraiser's method (application of a standard diminution percentage to the value of the property before the easement's donation) to be unreliable and his analysis unpersuasive. The Tax Court found the IRS's valuation expert, who determined that the value of the easement was zero, to be more persuasive. The IRS's expert opined, among other things, that the typical buyer would find the restrictions in the façade easement no more burdensome than local historic preservation restrictions and, even if the façade easement were more restrictive, it would not necessarily reduce the value of the property because homeowners in historic districts place a premium value on the assurance that the neighborhood surrounding their homes will remain unchanged over time. In Kaufman IV the Tax Court also sustained the IRS imposition of accuracy-related penalties.

The indefatigable Kaufmans appealed the holding imposing penalties to the First Circuit. In Kaufman V(discussed in Part III.B.2 below), the First Circuit affirmed, noting that the Tax Court did not clearly err when it found that the Kaufmans were liable for penalties for claiming a deduction for the donation of "a worthless historic preservation easement on their home."

(iii) Chandler. In Chandler, the Tax Court sustained the IRS's complete disallowance of deductions claimed with regard to two façade easement donations. As in Kaufman, the properties were

\footnotetext{
${ }^{150}$ For discussion of other issues in Kaufman, see Part II.B.2 above and Part II.F.1 and Part III.B below.

151 The First Circuit also noted "Section 170(h) does not allow taxpayers to obtain six-figure deductions for gifts of lesser or no value."
} 
located in Boston's South End Historic District and the easements were donated to NAT. Relying on its analysis in Kaufman IV, the court explained that, although there were minor differences (in scope, monitoring, and enforcement) between the easement restrictions and the restrictions already imposed by local law, those differences do not affect property values because a typical buyer would perceive no difference between the two sets of restrictions. The court did not find the taxpayer's appraisal, which asserted a $16 \%$ diminution in the value of the properties, to be credible. The appraiser who prepared the appraisal has been barred from preparing any kind of appraisal report or otherwise participating in the appraisal process for any property relating to federal taxes. ${ }^{152}$

d. Importance of Compliant Appraisals. Donors should not rely on appraisals that do not strictly comply with the qualified appraisal requirements or use questionable valuation methods or bases. ${ }^{153}$ While failures to strictly comply with the rules have been forgiven in some cases, in other cases they have resulted in complete disallowance of the claimed deductions. Moreover, even though an appraisal might be found to be a qualified appraisal, if it is poorly written, employs questionable methods or bases, or is otherwise unconvincing, it may nonetheless trigger an audit and, if litigated, the donor may be found to have failed to provide sufficient credible evidence of value. In situations where a donation has already been made and satisfaction of the qualified appraisal requirements is an issue on audit or in litigation, however, the decisions in Simmons II, Scheidelman II, Friedberg II, Irby, and Zarlengo may be helpful.

2. Conservation Easement-Specific Valuation Rules. Donors should strictly comply with the conservation easement-specific valuation rules in Treasury Regulation $\S 1.170 \mathrm{~A}-14(\mathrm{~h})(3)$, including the "entire contiguous parcel" and "enhancement" rules.

a. Pursuant to the entire contiguous parcel rule, ${ }^{154}$ the amount of the deduction in the case of a conservation easement covering a portion of contiguous property owned by the donor and the donor's "family" is the difference between the fair market value of the entire contiguous parcel before and after the granting of the easement.

b. Pursuant to the enhancement rule, ${ }^{155}$ if the granting of a conservation easement has the effect of increasing the value of any other property owned by the donor or a "related person," the amount of the deduction must be

\footnotetext{
152 See Part I.O above.

${ }^{153}$ For the IRS's view of appraisals, see Nonprofit Law Professors Blog, IRS on Conservation Easement Appraisals, at http://bit.ly/1UqHbTl.

${ }^{154}$ The entire contiguous parcel rule is found in the fourth sentence of Treasury Regulation $\S 1.170 \mathrm{~A}-14(\mathrm{~h})(3)(\mathrm{i})$.

155 The enhancement rule is found in the fifth sentence of Treasury Regulation $\S 1.170 \mathrm{~A}-14(\mathrm{~h})(3)(\mathrm{i})$.
} 
reduced by the amount of the increase in the value of the other property, whether or not such property is contiguous.

c. IRS Office of Chief Counsel Advice 201334039 (CCA) provides helpful guidance on the application of the entire contiguous parcel and enhancement rules. ${ }^{156}$

(i) The CCA discusses the meaning of the term "family" for purposes of the entire contiguous parcel rule, the meaning of the term "related person" for purposes of the enhancement rule, and rules relating to constructive ownership and entity classification and their impact on both the entire contiguous parcel and enhancement rules. The CCA provides twelve examples of the application of these rules to various situations involving property owned by individuals and entities (LLCs, partnerships, and corporations).

(ii) The CCA also explains in a footnote that, for purposes of the entire contiguous parcel rule, whether the entire contiguous parcel is valued as one large property or as separate properties depends on the highest and best use of the entire contiguous parcel. ${ }^{157}$

3. File Qualified Appraisal with Income Tax Return. The IRS has informally suggested that a copy of the qualified appraisal be included in the package filed with the income tax return on which a deduction for the easement donation is first claimed even if the appraised value of the easement is $\$ 500,000$ or less. If possible, the qualified appraisal should include a copy of the recorded (date stamped) conservation easement deed. In all cases, the appraiser should have valued the restrictions as they appear in the final recorded easement deed rather than in an earlier draft.

\section{Contemporaneous Written Acknowledgment}

1. IRC \& 170(f)(8) Requirements. No deduction is allowed for a charitable contribution of $\$ 250$ or more unless the taxpayer substantiates the contribution with a contemporaneous written acknowledgment (CWA) obtained from the donee. ${ }^{158}$

a. A CWA must include the following information:

(i) the amount of cash and a description (but not value) of any property other than cash contributed,

\footnotetext{
156 IRS Chief Counsel Advice 201334039 (released Aug. 23, 2012), available at http://www.irs.gov/pub/irswd/1334039.pdf.

157 See IRS on Conservation Easement Appraisals, supra note 153 (discussing this issue).

${ }^{158}$ IRC $\S 170(f)(8)(A)$. While not a conservation easement donation case, Van Dusen v. Comm'r, 136 T.C. 515, contains a detailed discussion of the CWA requirement.
} 
(ii) whether the donee provided any goods or services in consideration, in whole or in part, for the contributed property, and

(iii) if goods and services were provided, a description and good faith estimate of the value of such goods or services. ${ }^{159}$

b. A CWA will be contemporaneous only if the taxpayer obtains it on or before the earlier of

(i) the date on which the taxpayer files a return for the taxable year in which the contribution was made, or

(ii) the due date (including extensions) for the filing of such return. ${ }^{160}$

2. Form 990 Filing Insufficient. Failure of a donor to obtain a CWA cannot be cured by having the donee file a Form 990 containing the required information. In 15 West 17th St. LLC, the Tax Court held that $\S 170(f)(8)(D)$ 's exception to the CWA requirement, which provided that the requirement shall not apply if the donee files a return including the CWA information "on such form and in accordance with such regulations as the Secretary may prescribe," was not available because the Treasury had not issued such form or regulations. ${ }^{161}$ The Tax Cuts and Jobs Act signed into law by President Trump on December 22, 2017, repealed the $\S$ 170(f)(8)(D) exception to the CWA requirement for contributions made in tax years beginning after December 31, 2016. ${ }^{162}$

3. Substantial Compliance Doctrine Inapplicable. As noted in 310 Retail LLC, "“[t]he doctrine of substantial compliance does not apply to excuse failure to obtain a CWA meeting the statutory requirements." To justify the seeming harshness of the rule disallowing a deduction for failure to obtain a CWA, the Ninth Circuit explained: "The deterrence value of section 170(f)(8)'s total denial of a deduction comports with the effective administration of a self-assessment and self-reporting system."163

\section{No Particular Form Required but Form 8283 is not a CWA.}

a. As noted in 310 Retail $L L C$, a CWA need not take any particular form and may be furnished to the donor by (for example) letter, postcard, or computer-generated media. Whatever form the acknowledgment takes,

\footnotetext{
${ }^{159}$ IRC $\S 170(f)(8)(B)$.

${ }^{160}$ IRC $\S 170(\mathrm{f})(8)(\mathrm{C})$.

${ }^{161}$ See also 310 Retail LLC; Big River Development, LP; IRS Chief Counsel Advice 201120022 (May 20, 2011). 15 West 17th St. LLC involved a New York facade easement for which the taxpayer claimed a $\$ 64,490,000$ deduction. The property had been acquired $2 \frac{1}{2}$ years before the donation for $\$ 10$ million, and the taxpayer was positing that the property had appreciated in value by almost $600 \%$ during that time. By deciding the case on lack of CWA grounds, the court avoided the fact-intensive valuation issue.

162 Pub. L. 115-97, § 13705.

163 See Addis v. Commissioner, 374 F.3d 881 (9th Cir. 2004).
} 
however, it must include all of the information required by $\S 170(\mathrm{f})(8)(\mathrm{B})$, including an affirmative indication that the donee has provided no goods or services to the donor, if that is the case.

b. An IRS Form 8283 (appraisal summary), even if fully completed, does not constitute a CWA because only Section B, Part IV of that form constitutes a donee acknowledgement, and that acknowledgement does not contain all of the information required by $\S 170(\mathrm{f})(8)(\mathrm{B}) .^{164}$

5. Case Law Unpredictable. In Schrimsher and French, the Tax Court held that the conservation easement deed could not serve as a CWA. See also Bruzewicz (letter identifying cash contributions relating to façade easement donation was not a CWA; doctrine of substantial compliance inapplicable) and Didonato (settlement agreement was not a CWA). In Simmons I, ${ }^{165}$ Averyt, RP Golf I, 310 Retail LLC, and Big River Development, $L P$, however, the Tax Court held that the conservation easement deed could serve as a CWA. And in Irby, the Tax Court held that documents associated with the bargain sale of two easements collectively constituted a CWA. Given the fact-specific holdings in the cases, donors should not rely on a conservation easement deed or other documentation to serve as the CWA. Rather, donors should always obtain a separate CWA from the donee.

6. Safety Valve. Some government entities accepting conservation easement donations have refused to provide donors with a CWA. Donors and their counsel should discuss this issue early on with a prospective government holder. To address this issue and, in general, to serve as both a good "safety valve" and a reminder to the parties, some practitioners include a statement in the easement deed that (i) no goods or services were provided by the donee in consideration for the easement (if that is the case) and (ii) the donee agrees to provide the donor with a separate letter containing the information required by $\S 170(\mathrm{f})(8)$.

\section{E. Compelling and Timely Baseline Documentation}

1. The Treasury Regulations require that an easement donor make available to the donee, prior to the time the donation is made, documentation sufficient to establish the condition of the subject property at the time of the gift ("baseline documentation"). ${ }^{166}$

\footnotetext{
${ }^{164}$ See Final Substantiation and Reporting Regulations, supra note 131, at 36419.

${ }^{165}$ In Simmons I, Tax Court Judge Goeke stated that the easement deed could serve as a CWA. However, the donee in Simmons had provided the donor with a separate letter that complied with the statutory CWA requirements, so it is not clear why the Judge addressed the issue. The judge did not fully discuss whether or how the easement deed satisfied the CWA requirements.

${ }^{166}$ See Treas. Reg. $§ 1.170 \mathrm{~A}-14(\mathrm{~g})(5)(\mathrm{i})$. Although this requirement is applicable only if the "donor reserves rights the exercise of which may impair the conservation interests associated with the property," that will almost always be the case. Moreover, it is common practice and recommended that this requirement be satisfied with regard to every conservation easement donation because it helps to ensure the holder will have the information needed to properly enforce the easement.
} 
a. The baseline documentation must describe in detail the subject property and its open space, habitat, scenic, historic, and other conservation values. In addition, if the easement deed contains restrictions with regard to a particular natural resource to be protected, such as water quality or air quality, then the condition of that resource at or near the time of the gift must also be established in the baseline documentation. ${ }^{167}$

b. The baseline documentation must be accompanied by a statement signed by the donor and a representative of the donee clearly referencing the documentation and in substance stating: "This natural resources inventory is an accurate representation of [the protected property] at the time of the transfer" (referred to hereinafter as a "certification"). ${ }^{168}$

- In some cases, the parties have drafted the certification to provide that the parties agree the inventory (or baseline documentation) may be supplemented in the future (e.g., where the baseline documentation is prepared when the property is covered with snow). This has caused problems on audit. The baseline documentation must be fully completed prior to the time the donation is made. While annual or more frequent monitoring reports should be added to the file maintained for the easement following its donation, the baseline documentation is a snapshot of the condition of the property at the time of the easement's donation and should not be modified.

- Assuming the baseline documentation is timely completed, easement drafters may want to include language in the easement deed confirming that the baseline documentation is complete and that the parties agree that it is an accurate representation of the protected property at the time of the donation.

c. The baseline documentation should be detailed and compelling; it is the donor's best opportunity (as part of the tax filing) to persuade the IRS that the property has important conservation or historic values worthy of preservation. In some instances, easement donees hire qualified consultants to put together comprehensive and extensive baseline documentation. The Treasury Regulations, however, technically put the burden on the donor to make the baseline documentation available to the donee prior to the time the donation is made. ${ }^{169}$ Accordingly, it is the donor's responsibility to ensure that the baseline documentation requirements are satisfied.

d. The baseline documentation is also critical for enforcement purposes; it provides evidence of the condition of the property, including the property's conservation values and any improvements or incursions, on the date of the

167 Treas. Reg. $\S 1.170 \mathrm{~A}-14(\mathrm{~g})(5)(\mathrm{i})(\mathrm{D})$.

168 Treas. Reg. $\$ 1.170 \mathrm{~A}-14(\mathrm{~g})(5)(\mathrm{i})(\mathrm{D})$.

${ }^{169}$ See Treas. Reg. § 1.170A-14(g)(5)(i). 
donation. The Treasury Regulations explain that the purpose of the baseline is to "protect the conservation interests associated with the property, which although protected in perpetuity by the easement, could be adversely affected by the exercise of the reserved rights." 170 The baseline is thus essential to ensuring that the conservation purpose of the easement is "protected in perpetuity," and failure to timely prepare a fully completed baseline could be fatal to the deduction.

e. The IRS Conservation Easement Audit Techniques Guide provides that a comprehensive baseline study would generally include the following:

- A description of the encumbrance

- A description and map of the conservation characteristics and areas (i.e., listing of identified plants or wildlife)

- A map or series of maps depicting roads, fences, existing structures, trails, water bodies, wetlands, and any other property features

- Identification of any reserved building sites

- Surveys or plat maps

- Description of any management plans, such as a timber plan

- On-site photographs including aerial photographs

- The study author's name and professional credentials ${ }^{171}$

The Guide explains that the IRS examiner will need to assess the credibility of the baseline study. A baseline study prepared by an independent qualified expert such as a conservationist, biologist, forester or botanist would generally be given greater evidentiary weight than one prepared by a less qualified person or the taxpayer's self-assessment. Also, a baseline with a lot of documentary support is more credible than one with little support. ${ }^{172}$

The Guide further explains that some baseline studies are not propertyspecific and, instead, include a narrative about the general area or State without any specific reference to the donated property, and those baseline studies do not meet Treasury Regulation requirements. ${ }^{173}$

2. In Bosque Canyon Ranch, the Tax Court sustained the IRS's disallowance of $\$ 15.9$ million of deductions claimed for the donation of conservation easements to the North American Land Trust (NALT). Among other things, the court found that the baseline documentation reports, which NALT had prepared, were "slipshod" and "unreliable, incomplete, and insufficient to establish the condition of the relevant property on the date the respective easements were granted." Although the

\footnotetext{
170 Treas. Reg. $\S 1.170 \mathrm{~A}-14(\mathrm{~g})(5)(\mathrm{i})$.

${ }^{171}$ See IRS Conservation Easement Audit Techniques Guide, supra note 23, at 69.

172 See id., at 70.

173 See id., at 70.
} 
Fifth Circuit reversed the Tax Court, its opinion should not be viewed as a green light for shoddy and untimely baselines.

- Bosque Canyon Ranch is controlling only in the Fifth Circuit.

- Preparation of comprehensive baseline documentation at the time of the donation is in the interest of both the donor and the donee. Aside from the risk of having the deduction denied, if there is no or an incomplete record of the improvements and incursions on the subject property at the time the donation was made, it may be impossible for the holder to prove, at some later date, that a violation has occurred. Similarly, if there is no or an incomplete record of the condition of the conservation values the easement is intended to protect at the time the donation was made, it may be impossible for the holder to prove, at some later date, that such conservation values have been degraded or destroyed, or the extent of the damage or destruction.

3. The IRS routinely asks for the baseline documentation on audit.

\section{F. Correct and Timely Lender Agreement (if applicable)}

1. Full Subordination. Donors should obtain a lender agreement that subordinates the lender's rights to all of the rights of the holder under the conservation easement, including the holder's right to at least a minimum proportionate share of the proceeds received following extinguishment of the easement as specified in Treasury Regulation $\S 1.170 \mathrm{~A}-14(\mathrm{~g})(6)(\mathrm{ii}) .{ }^{174}$ Although the First Circuit took a somewhat liberal approach to this issue in Kaufman III, in Palmolive I the Tax Court indicated that it will not follow the First Circuit's holding regarding this issue in other circuits, and it appears that the IRS will continue to challenge deductions on this ground in other circuits.

a. Kaufman III. In Kaufman III, the First Circuit vacated the Tax Court's holdings in Kaufman $I$ and $I I$ that priority language in a lender agreement impermissibly limited the operation of the "proceeds" clause included in a facade easement to satisfy Treasury Regulation $\S 1.170 \mathrm{~A}-14(\mathrm{~g})(6)(\mathrm{ii})$. The lender agreement in Kaufman provided that, if the easement were extinguished as a result of a casualty event (such as a fire or flood) or condemnation, the bank holding an outstanding mortgage on the property

\footnotetext{
${ }^{174}$ For an example of such a "full subordination" clause, see the subordination agreement template of the Compact of Cape Cod Conservation Trusts, which provides:

[Name and address of financial institution] ("Mortgagee"), present holder of a mortgage from, [donors] ("Mortgagor"), recorded on [date] in the [County] Registry of Deeds in Deed Book [ ] Page [ ], for consideration paid, hereby recognizes and assents to the terms and provisions of a Conservation Restriction running to the Conservation Trust, to be recorded herewith, and agrees to subordinate and hold its mortgage subject to the terms and provisions of said Conservation Restriction to the same extent as if said mortgage had been recorded subsequent to the recording of the Conservation Restriction, and the undersigned shall, in the exercise of its rights pursuant to said instrument, recognize the terms and provisions of the aforesaid Conservation Restriction.
} 
had first priority to any insurance or condemnation proceeds. The Tax Court held that the easement, as qualified by the lender agreement, failed to satisfy Treasury Regulation $\S 1.170 \mathrm{~A}-14(\mathrm{~g})(6)(\mathrm{ii})$ because the intent of the drafters of that regulation was that the donee have a right to a share of the proceeds following extinguishment, and not merely a contractual claim against the owner of the property for an amount equal to such share. The First Circuit reversed, holding that it was sufficient that the donee had such a contractual claim against the owner.

In footnote 5 of Kaufman III, however, the First Circuit noted that Treasury Regulation $\S 1.170 \mathrm{~A}-14(\mathrm{~g})(2)$ (the "mortgage subordination" regulation) could be read broadly to require that a lender subordinate its rights to the donee's right to post-extinguishment proceeds, which, pursuant to Treasury Regulation $\S 1.170 \mathrm{~A}-14(\mathrm{~g})(6)(\mathrm{i})$, must be used by the donee to advance conservation purposes. The First Circuit noted that it did not pursue this issue because the IRS had "disclaimed" that broad reading of the mortgage subordination regulation in Kaufman III.

b. Palmolive I. In Palmolive I, which is appealable to the Seventh Circuit, the Tax Court declined to follow the First Circuit's holding in Kaufman III and, instead, reaffirmed its decisions Kaufman $I$ and $I I .{ }^{175}$ In Palmolive I, the easement deed and the lender agreements provided that two banks holding outstanding mortgages on the subject property had first priority to any insurance or condemnation proceeds. The Tax Court held that these priority rights violated both Treasury Regulation $\S 1.170 \mathrm{~A}-14(\mathrm{~g})(2)$ (the "mortgage subordination" regulation) and Treasury Regulation $\S 1.170 \mathrm{~A}-$ 14(g)(6)(ii) (the "proceeds" regulation).

Among other things, the Tax Court rejected the argument that the mortgage subordination regulation is satisfied as long as the lender is prevented from extinguishing the easement in foreclosure. The court explained that, if the mortgage subordination regulation was intended to require that a lender subordinate only its right to foreclose on the property to the rights of the donee, then the regulation would have been drafted to say that. Instead, the regulation requires that a lender subordinate its rights in the property

${ }^{175}$ In Irby, decided after Kaufman III, the Tax Court noted:

In cases involving a conservation easement where we determined that the regulation's requirements were not met and thus denied the claimed charitable contribution deduction, the grantee organization had been prevented by the deeds themselves from receiving the full proportionate value of the extinguishment proceeds.... The funds diverted by the deeds were used to further the donor taxpayer's interests. For example, in Wall, the deed of conservation easement provided that if the property was condemned, the grantee conservation organization would be entitled to the easement's proportionate value, but only after any claim of a mortgagee was satisfied. Hence, the first use of the extinguishment proceeds was to further the donor taxpayer's interest in repaying the mortgage on the property, with the grantee conservation organization's receiving only a residual amount of money.... Our conclusions in those cases (i.e., denying the deduction) reflect the purpose of the regulation. 
(including its rights to any insurance and condemnation proceeds) to the rights of the donee. ${ }^{176}$

The Tax Court also held that the "so remote as to be negligible" rule of Treasury Regulation $\S 1.170 \mathrm{~A}-14(\mathrm{~g})(3)$ is not an alternative provision on which taxpayers may rely if they otherwise fail to satisfy the express requirements of the regulations, like the mortgage subordination and extinguishment requirements.

Finally, the Tax Court rejected Palmolive's argument that a "savings clause" in the easement, which purportedly operated to amend the easement after the donation to the extent necessary to comply with the Treasury Regulations, saved the deduction. The court explained that the requirements of $\S 170$ and the Treasury Regulations must be satisfied at the time of the gift, and a savings clause cannot retroactively modify an easement to comply with such requirements.

\section{Mortgages Must be Subordinated at Time of Donation.}

a. Mitchell III. In Mitchell III, the Tenth Circuit affirmed the Tax Court's holdings in Mitchell $I$ and $I I$ that, to be eligible for a deduction for the donation of a conservation easement under $\S 170(\mathrm{~h})$, any outstanding mortgages on the underlying property must be subordinated to the rights of the holder of the easement at the time of the gift. This means the lender agreement should be recorded at the same time as the conservation easement.

(i) The Facts. The donor in Mitchell did not obtain a subordination agreement from the lender holding an outstanding mortgage on the subject property until almost two years following the date of the donation. The IRS argued that the mortgage subordination requirement in the Treasury Regulations is a bright-line requirement that requires any existing mortgage to be subordinated to the rights of the holder of the easement at the time of the gift, irrespective of

\footnotetext{
${ }^{176}$ See also Nancy A. McLaughlin, Internal Revenue Code Section 170(h): National Perpetuity Standards for Federally Subsidized Conservation Easements, Part 1, The Standards, 45 Real Prop. TR. \& Est. L.J. 473, 493 (2010), which explains:

The Treasury Regulations do not provide that a lender must subordinate its rights to the right of the holder to enforce the easement. Rather, the regulations provide that the lender must subordinate its rights to the rights of the holder to enforce the conservation purposes of the gift in perpetuity. That language embraces all of the elements of a donated easement's perpetual nature, not just the holder's right to enforce the particular restrictions in the easement. Thus, the holder's rights to which a lender must subordinate its rights should necessarily include, among other things, the holder's right to receive proceeds upon extinguishment of the easement to be used to replace lost conservation values as provided in Treasury Regulation section 1.170A$14(\mathrm{~g})(6)$. This makes sense from a policy perspective because the value attributable to the gift that was made for the benefit public and for which a federal subsidy was provided should remain in the charitable sector and be devoted to similar conservation purposes (as opposed to being paid to the landowner's lender). If the holder is not entitled to receive proceeds upon extinguishment because of a limited subordination agreement, the donation should not be deemed to comply with the statutory mandate that the conservation purpose of the contribution be protected in perpetuity. (emphasis added)
} 
the likelihood of foreclosure or any alternate safeguards. The IRS also asserted that subordination must occur at the time of the gift because, without subordination, the easement would be vulnerable to extinguishment upon foreclosure and, thus, the conservation purpose would not be protected in perpetuity as required under $\S$ 170(h). The Tenth Circuit agreed.

(ii) Deference to Commissioner. Citing to the U.S. Supreme Court's holding in Mayo Found. for Med. Educ. \& Research v. United States, 131 S.Ct. 704, 711 (2011), the Tenth Circuit explained that, because the Commissioner promulgated the regulations under $\S 170$ (h) pursuant to the authority granted to him by Congress, the regulations are binding unless they are "arbitrary and capricious in substance, or manifestly contrary to the statute." Where Congress has delegated to the Commissioner the power to promulgate regulations, said the court, "we must defer to his regulatory interpretations of the Code so long as they are reasonable." Requiring existing mortgages to be subordinated to conservation easements prevents extinguishment of the easements in the event the landowners default on the mortgages. In this way, said the Tenth Circuit, the mortgage subordination requirement is "reasonably related" to Congress's mandate in $\S 170(\mathrm{~h})(5)(\mathrm{A})$ that the conservation purpose of an easement be "protected in perpetuity."

- The Tenth Circuit also rejected the donor's claim that the mortgage subordination regulation is arbitrary and capricious, and therefore unenforceable. Although declining to consider that argument because it was raised for the first time on appeal, the Tenth Circuit noted that the argument would fail because the regulation is "a reasonable exercise of the Commissioner's authority to implement the statute."

(iii) Subordination Must Be Timely. The donor in Mitchell argued that, since the mortgage subordination regulation contains no explicit time frame for compliance, it should be interpreted to allow for subordination to occur at any time. The Tenth Circuit rejected this argument, noting that the regulation "expressly provides that subordination is a prerequisite to allowing a deduction." The Tenth Circuit further noted that, even if it were to view the regulation as ambiguous with respect to timing, the result would be no different because the court must defer to the Commissioner's reasonable interpretation on this point.

(iv) Functional Subordination Not Sufficient. The donor in Mitchell argued that strict compliance with the mortgage subordination requirement was unnecessary because the easement deed allegedly contained sufficient safeguards to protect the conservation purpose 
in perpetuity. The Tenth Circuit rejected this argument as inconsistent with the plain language of the mortgage subordination provision. The court pointed out that the regulation contains one narrow exception to the "unambiguous" subordination requirement-for donations occurring prior to $1986 .{ }^{177}$ In the case of a pre-1986 donation, a taxpayer may be entitled to a deduction without subordination if the taxpayer can demonstrate that the conservation purpose is nonetheless protected in perpetuity. The negative implication of this express, time-limited exception, said the court, is that no alternative to subordination will suffice for post1986 donations. ${ }^{178}$

(v) Likelihood of Foreclosure Irrelevant. The donor in Mitchell argued that strict compliance with the mortgage subordination requirement was unnecessary in her case because the risk of foreclosure was "so remote as to be negligible" (the partnership that donated the easement apparently paid its debts on time and had sufficient assets to satisfy in full the amounts due). ${ }^{179}$ The donor pointed to Treasury Regulation $\S 1.170 \mathrm{~A}-14(\mathrm{~g})(3)$, which provides that a deduction will not be disallowed merely because the interest that passes to the donee organization may be defeated by the happening of some future event, "if on the date of the gift it appears that the possibility that such ... event will occur is so remote as to be negligible." She argued that this provision acts as an exception to the mortgage subordination provision-i.e., that because the risk of foreclosure in her case was arguably so remote as to be negligible, failure to satisfy the mortgage subordination requirement should be forgiven.

- The Tenth Circuit rejected this argument, holding that the "so-remote-as-to-be-negligible" provision cannot be reasonably read as modifying the strict mortgage subordination requirement. In promulgating the rules, explained the court, the Commissioner specifically considered the risk of mortgage foreclosure to be neither remote nor negligible, and therefore chose to target the accompanying risk of extinguishment of the conservation easement by strictly requiring mortgage subordination.

\footnotetext{
177 The mortgage subordination requirement first appeared when the Treasury Regulations were finalized in 1986, hence the 1986 effective date.

${ }^{178}$ In Palmolive I, the Tax Court similarly explained:

The different regime for contributions before February 1986 should be noted: Literal subordination was not required, as long as "protect[ion] in perpetuity" by other means could be demonstrated. For subsequent contributions, "no deduction will be permitted" without subordination.

${ }^{179}$ A partnership of which Ms. Mitchell was a partner donated the easement. For convenience purposes, Ms. Mitchell is referred to as the donor in this summary.
} 
- The Tenth Circuit also noted that, even if the regulations were unclear with respect to the interplay between the mortgage subordination and remote future event provisions, the donor would not prevail because the court is required to defer to the Commissioner's interpretation to resolve any ambiguity unless it is "plainly erroneous or inconsistent with the regulations" or there is any other "reason to suspect the interpretation does not reflect the agency's fair and considered judgment on the matter." "[I]t is reasonable," said the court, "for the Commissioner to adopt an easilyapplied subordination requirement over a case-by-case, factspecific inquiry into the financial strength or credit history of each taxpayer." The court quoted a law review article in support of its holding:

The specific requirements in the Code and Treasury Regulations establish bright-line rules that promote efficient and equitable administration of the federal tax incentive program. If individual taxpayers could fail to comply with such requirements and claim that their donations are nonetheless deductible because the possibility of defeat of the gift is so remote as to be negligible, the Service and the courts would be required to engage in an almost endless series of factual inquiries with regard to each individual conservation easement donation. ${ }^{180}$

b. Minnick III. In Minnick III, the Ninth Circuit affirmed the Tax Court's holding in Minnick I that, to be eligible for a deduction for the donation of a conservation easement, any outstanding mortgages on the underlying property must be subordinated to the rights of the holder of the easement at the time of the gift.

(i) Citing to Mitchell III, the Ninth Circuit explained that the plain language of the mortgage subordination regulation supports the Tax Court's interpretation. The regulation specifies that "no deduction will be permitted ... unless the mortgagee subordinates its rights in the property." Strictly construed, said the Ninth Circuit, that language makes clear that "subordination is a prerequisite to allowing a deduction." Since there was no dispute that Minnick's lender had not subordinated its rights in the subject property when Minnick donated the easement at issue (despite warranties in the easement deed to the contrary), under the plain meaning of the regulation no deduction was permitted.

180 Nancy A. McLaughlin, Internal Revenue Code Section 170(h): National Perpetuity Standards for Federally Subsidized Conservation Easements Part 1: The Standards, 45 Real Prop. TR. \& Est. L.J. 473, 505-06 (2010). 
(ii) The Ninth Circuit further explained that, even if the regulation was deemed ambiguous, that would not change the outcome. Under Auer v. Robbins, 519 U.S. 452 (1997), courts defer to the IRS's reasonable interpretation of its own regulations and, as explained in Mitchell III, the IRS's interpretation is reasonable and not plainly erroneous or inconsistent with the regulation. The Ninth Circuit noted:

An easement can hardly be said to be protected 'in perpetuity' if it is subject to extinguishment at essentially any time by a mortgage holder who was not a party to, and indeed (as here) may not even have been aware of, the agreement between the Taxpayers and a [land] trust.

(iii) In Minnick II, an unpublished opinion issued the same day as Minnick III, the Ninth Circuit addressed the remaining issues in Minnick, holding for the IRS on each point.

- Like the Tenth Circuit in Mitchell III, the Ninth Circuit in Minnick II held that the taxpayer's failure to comply with the mortgage subordination requirement could not be excused by invoking the so-remote-as-to-be-negligible regulation.

- The Minnicks argued that their failure to obtain a timely subordination agreement should be excused because there was "verifiable evidence of original intent to enforce the easement in perpetuity" in the easement deed, which specifically stated that there were "no outstanding mortgages...in the Property that have not been expressly subordinated to the Easement." The Ninth Circuit rejected this argument, explaining that, even if the statement in the deed evidenced an intent to subordinate, intent is irrelevant. A mortgage must be subordinated at the time of the gift.

- The Minnicks argued that Idaho's cy pres doctrine, which "restricted the Minnicks from abandoning or otherwise encumbering the easement," adequately ensured that the easement would continue in perpetuity and, thus, the subordination requirement was satisfied. The Ninth Circuit rejected this argument, noting that the "cy pres doctrine is inapplicable here because it has no effect on the ability of the bank holding the unsubordinated mortgage to extinguish the easement by foreclosure." Cy pres would have no effect on the ability of the bank to extinguish the easement in the event of foreclosure because the easement had been granted to the 
land trust subject to the mortgage and, thus, the bank's rights had priority over those of the land trust and the public.

- The Minnicks argued that the Tax Court improperly imposed a $20 \%$ negligence penalty on them under IRC $\S 6662(a)$. The Ninth Circuit rejected this argument, explaining that the Minnicks did not have reasonable cause for claiming a deduction because Mr. Minnick had a law degree and reading the Treasury Regulations would have given him notice that subordination may have been required.

(iv) Mr. Minnick (a former member of the U.S. House of Representatives from Idaho) sued his attorney for malpractice. The Idaho Supreme Court ruled that the suit was not barred by the statute of limitations. ${ }^{181}$

c. RP Golf III. In RP Golf III, the Eighth Circuit affirmed the Tax Court's holding in $R P$ Golf II that, to be eligible for a deduction for the donation of a conservation easement, any outstanding mortgages on the underlying property must be subordinated to the rights of the holder of the easement at the time of the gift. In RP Golf II, the Tax Court sustained the IRS's disallowance of a $\$ 16.4$ million deduction for the donation of a conservation easement on two private golf courses in Kansas City, Missouri. Although the IRS challenged the claimed deduction on a number of grounds (including failure to satisfy the conservation purposes test, overvaluation, and the taxpayer's lack of ownership of a portion of the subject property), in RP Golf II, the Tax Court denied the deduction because the taxpayer failed to obtain subordination agreements at the time of the gift of the easement. The Tax Court considered and rejected the taxpayer's argument that the lenders had orally agreed to subordinate their interests before the date of the gift, finding no evidence of a binding oral or written agreement under state law. The Tax Court explained that, because the easement could have been extinguished by foreclosure after the date of the gift, the easement "was not protected in perpetuity and, therefore, was not a qualified conservation contribution." In affirming the Tax Court, the Eighth Circuit relied in part on Mitchell and Minnick and determined that the Tax Court's finding that there were no oral agreements to subordinate was not clearly erroneous.

G. So-Remote-As-To-Be-Negligible Does Not Cure Noncompliance. Based on the holdings in numerous cases, the "so-remote-as-to-be-negligible" provision ${ }^{182}$ will not cure

\footnotetext{
${ }^{181}$ Legal Malpractice Lawyer Blog, Minnick v. Ennis, No. 41663: Supreme Court of Idaho Remands Dismissal of Legal Malpractice Case, http://www.legalmalpracticelawyer.com/2015/01/22/461/ (last visited April 25, 2015).

182 Treasury Regulation $\S 1.170 \mathrm{~A}-14(\mathrm{~g})(3)$ provides in part:

[a] deduction shall not be disallowed ... merely because the interest which passes to, or is vested in, the donee organization may be defeated by the performance of some act or the happening of some event, if on the date of the gift it appears that the possibility that such act or event will occur is so remote as to be negligible.
} 
noncompliance with a specific requirement in the $\S 170(\mathrm{~h})$ or the Treasury Regulations. Below is a sampling of the relevant cases. ${ }^{183}$

1. In Carpenter I, the Tax Court held that the "so-remote-as-to-be-negligible" provision does not modify Treasury Regulation $\S 1.170 \mathrm{~A}-14(\mathrm{~g})(6)(\mathrm{i})$. Thus, failure to comply with the extinguishment requirements of Treasury Regulation $\S 1.170 \mathrm{~A}-$ 14(g)(6)(i) cannot be cured by a showing that the possibility of extinguishment is so remote as to be negligible.

2. In Mitchell I, the Tax Court explained that the so-remote-as-to-be-negligible standard cannot be used to avoid any of the following specific requirements: (i) Treasury Regulation $\S 1.170 \mathrm{~A}-14(\mathrm{~g})(2)$ 's mortgage subordination requirement, (ii) Treasury Regulation $\S 1.170 \mathrm{~A}-14(\mathrm{~g})(6)(\mathrm{i})$ 's judicial proceeding requirement, or (iii) Treasury Regulation $\S 1.170 \mathrm{~A}-14(\mathrm{~g})(6)(\mathrm{ii})$ 's proceeds requirement.

3. In Mitchell III, the Tenth Circuit noted that the D.C. Circuit in Simmons did not excuse the taxpayer from complying with the mortgage subordination requirement, or excuse noncompliance with any express precondition to taking a deduction contained in the regulations. Rather, it applied the so-remote-as-to-be-negligible provision to allow a deduction despite the risk of noncompliance with $\S 1.170 \mathrm{~A}-$ 14's more general perpetuity requirement. Thus Simmons does not support an interpretation that the so-remote-as-to-be-negligible provision will excuse noncompliance with the mortgage subordination provision's plain and specific mandate that "no deduction will be permitted...unless" the mortgage is subordinated. The Tenth Circuit also noted that Kaufman III similarly "provides little guidance." In Kaufman III the First Circuit held that the taxpayer was entitled to a deduction because the donation satisfied the in perpetuity requirement, but specifically declined to address whether the taxpayer had complied with the mortgage subordination provision or to base its holding on the so-remote-as-to-benegligible provision.

4. In Palmolive I, the Tax Court explained that:

Paragraph $(\mathrm{g})(3)$ of section $1.170 \mathrm{~A}-14$ is not an alternative provision on which taxpayers may rely if they otherwise fail to satisfy the express requirements of paragraph $(\mathrm{g})(2)$ or $(\mathrm{g})(6) \quad \ldots$ regularly occurring circumstances that are expressly foreseen and are explicitly provided for in the regulations (i.e., mortgages and extinguishment proceeds) are by their nature not "remote", and the specific requirements in the regulations as to those contingencies are not affected by paragraph $(g)(3)$.

${ }^{183}$ See also Hoffman Order (discussed in Part II.A.13 above), and Wachter, Carroll, and Salt Point Timber. 


\section{Other Important Issues}

A. Valuation. For a comprehensive discussion of conservation and facade easement valuation rules and the relevant valuation case law through 2015, see Nancy A. McLaughlin, Conservation Easements and the Valuation Conundrum. ${ }^{184}$ For cases involving valuation after 2015, see, e.g., Gemperle, Palmer Ranch, Mountanos, McGrady, Wendell Falls, PBBM Rose-Hill II, Pine Mountain I. ${ }^{185}$

\section{B. Penalties.}

1. Penalty Provisions. As part of the Pension Protection Act of 2006 (the PPA), Congress expanded the circumstances under which penalties can be imposed for overvaluations. Before enactment of the PPA, a substantial valuation misstatement (subject to a $20 \%$ penalty) existed if the value of property reported on a tax return was two times $(200 \%)$ or more of the amount determined to be the correct value. A gross valuation misstatement (subject to a $40 \%$ penalty) existed if the value reported on a tax return was four times $(400 \%)$ or more of the amount determined to be the correct value. ${ }^{186}$ Taxpayers could avoid these penalties if they made the valuation misstatement in good faith and with reasonable cause.

The PPA lowered the threshold from $200 \%$ to $150 \%$ for a substantial valuation misstatement and from $400 \%$ to $200 \%$ for a gross valuation misstatement. The PPA also eliminated the reasonable cause exception for gross valuation misstatements of charitable deduction property, making that penalty a strict liability penalty. The PPA further enacted new penalties for preparers of an appraisal to be used to support a tax position if the appraisal results in a substantial or gross valuation misstatement. ${ }^{187}$ The PPA changes apply to (i) returns claiming deductions for façade easement donations that are filed after July 25, 2006, and (ii) returns claiming deductions for donations of easements encumbering land that are filed after August 17, 2006. ${ }^{188}$

2. Case Law. Below is a sampling of court holdings regarding penalties. For additional more recent cases involving penalties, see, e.g., Partita Partners II, Graev III, Roth, PBBM Rose-Hill II, and Palmolive II.

a. Kaufman $V$. In Kaufman $V$, the First Circuit affirmed the Tax Court's holding in Kaufman $I V$ that the Kaufmans were liable for gross valuation misstatement penalties for claiming a deduction "for a worthless historic preservation easement on their home." Because the Kaufmans' returns were

\footnotetext{
${ }^{184}$ Available at http://papers.ssrn.com/sol3/papers.cfm?abstract id=2704576.

${ }^{185}$ For a recent case that did not involve a conservation easement donation but discusses the definition of "fair market value" for charitable deduction purposes, see Grainger v. Comm'r, T.C. Memo. 2018-117.

${ }^{186}$ If the correct value of an easement is determined to be zero, the value claimed on the taxpayer's return is deemed to be $400 \%$ or more of the correct amount and, thus, a gross valuation misstatement. See Treas. Reg. § 1.6662-5(g).

187 See IRC $\S 6695 \mathrm{~A}$.

${ }^{188}$ For an explanation of the Pension Protection Act of 2006 (PPA) changes, see JCT Explanation of Pension Protection Act of 2006, supra note 17. See also Chandler (discussing the PPA effective dates).
} 
filed before the effective date of the PPA, the gross valuation misstatement penalty was not a strict liability penalty. However, the Kaufmans were unable to avoid penalties by showing that they made a good-faith investigation of the value of the easement or acted with reasonable cause and in good faith. This was due, in large part, to the following factors.

- The Kaufmans represented in a letter to the lender holding an outstanding mortgage on the subject property (for purposes of obtaining a subordination agreement) that "[t]he easement restrictions are essentially the same restrictions as those imposed by current local ordinances that govern this property."

- The Kaufmans used an appraiser that the donee-the National Architectural Trust (NAT) - both recommended and taught to do façade easement appraisals. NAT also suggested language for the appraiser to include in his appraisals, which he incorporated "almost verbatim" into all of his reports, regardless of the property involved. The First Circuit further noted that the appraiser "at least arguably had an incentive to calculate a high value for the easement, given that he performed appraisals for [NAT] and [NAT] received cash donations corresponding to a set percentage of the assessed value of the donated easements."

- After receiving the appraisal indicating that the easement would reduce the value of their home by $\$ 220,800$ (or by $12 \%$ ), Dr. Kaufman expressed concern to NAT that the reduction in the resale value of the home would be so large as to "overwhelm the tax savings" from the donation. In a "smoking gun email," NAT responded that façade easements do not actually reduce the value of the properties they encumber. Among other things, the email noted:

One of our directors, Steve McClain, owns fifteen or so historic properties and has taken advantage of this tax deduction himself. He would never have granted any easement if he thought there would be a risk or loss of value in his properties.

Despite the evidence indicating that the easement had no value, the Kaufmans proceeded to claim a $\$ 220,800$ deduction. The First Circuit agreed with the Tax Court that "the Kaufmans should have recognized obvious warning signs indicating that the appraisal's validity was subject to serious question, and should have undertaken further analysis in response." The First Circuit further noted that the Tax Court did not purport to equate "good faith investigation" with "exhaustive investigation." Rather, it "merely required that the Kaufmans do some basic inquiry into the validity of an appraisal whose result was squarely contradicted by other available evidence glaringly in front of them." The Kaufmans were highly intelligent 
and very well educated, said the First Circuit, 189 "and the Tax Court reasonably found that developments casting doubt on the... appraisal should have alerted them that they needed to take further steps to assess their "proper tax liability."'

The First Circuit also noted that decisions in which the courts have declined to impose penalties (Whitehouse, Chandler, Zarlengo, and Scheidelman) were not inconsistent with its conclusion to impose penalties in Kaufman V. In contrast to Kaufman, there were no "red flags" in those other cases suggesting that the easements had no value.

b. Chandler. In Chandler, the Tax Court sustained the IRS's complete disallowance of deductions claimed with regard to two façade easement donations on the same grounds as in Kaufman (the easements had no value because the typical buyer would find the easement restrictions no more burdensome than local historic preservation restrictions). The taxpayers in Chandler claimed deductions with regard to the easement donations on their 2004, 2005, and 2006 returns and, because the Tax Court determined the easements had no value, the valuation misstatement for each year was a gross valuation misstatement. Chandler raised the novel issue of whether the taxpayers could assert the reasonable cause defense for the underpayment on their 2006 return (despite the PPA having made the gross valuation misstatement penalty a strict liability penalty with regard to returns filed after August 17, 2006) because the underpayment was the result of a carryover of deductions from their 2004 return. The taxpayers argued that denying their right to raise a reasonable cause defense with regard to their 2006 return would amount to retroactively applying the PPA. The Tax Court disagreed, noting that (i) the penalty statute as revised by the PPA by its plain language applies to returns filed after a certain date and (ii) when the taxpayers filed their 2006 return they "reaffirmed" the easement's grossly misstated value. For similar holdings, see Reisner and Mountanos III.

The court in Chandler did, however, find that the taxpayers were not liable for penalties for their 2004 and 2005 underpayments because they underpaid with reasonable cause and in good faith. The IRS argued that Mr. Chandler should have known the easements were overvalued because he was well educated (he had a JD and an MBA). The Tax Court disagreed, noting that even experienced appraisers find valuing conservation easements difficult, and the flaws in the appraisals would not have been evident to the Chandlers. The court also distinguished Kaufman because the Kaufmans had been assured by the donee that their easement would not reduce the value of the property. In Chandler there was no evidence that the taxpayers had similarly relied on appraisals in bad faith.

${ }^{189}$ Dr. Kaufman was an emeritus professor of statistics at MIT and Mrs. Kaufman was a company president with a Ph.D. in psychology. 
c. Gorra. In Gorra, the Tax Court rejected the taxpayers' argument that the gross valuation misstatement penalty was an "excessive fine" under the Eighth Amendment to the United States Constitution, noting that such penalties are remedial in nature, not "punishments," and are an important tool because they enhance voluntary compliance with tax laws.

d. Legg. In Legg, the Tax Court held that the IRS's determination that the Leggs were liable for strict liability $40 \%$ gross valuation misstatement penalties was proper. The Leggs argued that the IRS examiner had not made an "initial determination" of the $40 \%$ penalties as required by IRC $\S$ $6751(\mathrm{~b})(1)$ because the examination report calculated the penalties using the $20 \%$ rate and the $40 \%$ penalties were posed only as an alternative position. The Tax Court disagreed, explaining that Congress enacted $\S 6751(\mathrm{~b})$ to ensure that taxpayers understand the penalties imposed on them and the examination report sent to the Leggs clearly explained why the Leggs were liable for the $40 \%$ penalties. Accordingly, the IRS satisfied the procedural requirements of $\S 6751(\mathrm{~b})$ and imposition of the $40 \%$ penalties was proper.

e. Carroll. In Carroll, the Tax Court sustained the IRS's disallowance of deductions claimed with regard to the donation of a conservation easement because the easement contained a noncompliant "proceeds" clause. The court also found that the taxpayers were liable for $20 \%$ accuracy-related penalties and did not qualify for the reasonable cause exception to those penalties. The court explained that one of the taxpayers was a highly educated medical school graduate who had previous experience with conservation easements; although the taxpayers had hired an attorney to draft a related gift deed for the subject property, that attorney was not a tax attorney and " $\mathrm{d}[\mathrm{id}]$ not answer tax-related questions or give tax advice;" the taxpayers offered no evidence that would explain why the terms of the easement varied from the proceeds requirement in the Treasury Regulation; and the taxpayers did not explain why they failed to seek competent advice from a tax attorney or other adviser to ensure that the easement complied with the pertinent regulations. The court concluded that, in the light of the high level of sophistication of one of the taxpayers and his experience with conservation easements, the taxpayers did not demonstrate that they acted with reasonable cause and in good faith in not seeking competent tax advice regarding the donation. The court declined to impose substantial or gross valuation misstatement penalties, however, because the IRS did not assert those penalties on a timely basis.

C. Date of Donation and Recordation Date. Treasury Regulation $\S 1.170 \mathrm{~A}-14(\mathrm{~g})(1)$ provides:

any interest in the property retained by the donor (and the donor's successors in interest) must be subject to legally enforceable restrictions (for example, by recordation in the land records of the jurisdiction in which the property is located) 
that will prevent uses of the retained interest inconsistent with the conservation purposes of the donation.

The donor of a conservation easement should see to it that the easement is recorded in the year in which the donor intends to claim the donation was made. Absent recordation of an easement, a purchaser of the subject property who records the purchase deed will generally take the property free of the easement. In addition, many state conservation easement enabling statutes specifically require recordation for an easement to be legally enforceable. ${ }^{190}$ Accordingly, absent recordation in the year of the purported donation, the IRS can argue that the easement was not "granted in perpetuity" and its conservation purpose was not "protected in perpetuity" in that year.

1. IRS Position on Year of Donation. The IRS Conservation Easement Audit Techniques Guide provides that "An easement is not enforceable in perpetuity before it is recorded." 191 The Guide further instructs that, "for conservation easements, the year of the deduction is the year of recordation" and provides the following as an example:

A conservation easement was granted to a qualified organization on December 20, 2007, as evidenced by the dated signatures on the conservation easement deed. However, the easement was not recorded in the public records until March 12, 2008. The year of donation is 2008. ${ }^{192}$

The Guide also instructs that, in addition to the easement deed, all exhibits or attachments to the deed, such as diagrams and lender agreements, may need to be recorded. ${ }^{193}$

\section{Case Law.}

a. Gorra. Gorra involved a donation to the National Architectural Trust (NAT) of a façade easement on a building in the Carnegie Hill Historic District of New York City. NAT delivered the easement to the recorder's office on December 28, 2006, paid the recording fees and taxes, and obtained a receipt for the delivery. Due to a cover sheet error, however, the easement was not recorded until January 18, 2007. The IRS argued that the deed was not recorded until 2007. The Tax Court disagreed, holding that, under New York law, delivery of the deed to the recorder's office, with receipt acknowledged, constituted recordation, even though there was a delay in the actual recording until the following year because of the cover sheet error. The court cited N.Y. Real Prop. Law $\S 317$, which provides that

\footnotetext{
${ }^{190}$ For example, the Uniform Conservation Easement Act provides that "[n]o right or duty in favor of or against a holder and no right in favor of a person having a third-party right of enforcement arises under a conservation easement before its acceptance by the holder and a recordation of the acceptance." Uniform Conservation Easement Act § 2(b) (Last Revised or Amended in 2007).

${ }^{191}$ See IRS Conservation Easement Audit Techniques Guide, supra note 23, at 12.

${ }^{192}$ Id., at 9.

${ }^{193} I d$., at 12 .
} 
every instrument entitled to be recorded is considered recorded from the time of delivery to the recording officer.

b. Zarlengo. Zarlengo involved a donation to NAT of a façade easement on a building in a Manhattan historic district. The easement donors and NAT signed the easement in 2004, NAT sent the donors a letter thanking them for the donation in 2004, and the donors claimed deductions for the donation on their 2004 returns. For reasons not explained in the Tax Court's opinion, however, the easement was not recorded until January 26, 2005. The IRS argued that the taxpayers were not entitled to deductions in 2004 because the façade easement was neither (i) a "qualified real property interest" as defined in $\S 170(\mathrm{~h})(2)(\mathrm{C})$ (i.e., "a restriction (granted in perpetuity) on the use which may be made of the real property") nor (ii) donated exclusively for conservation purposes as required under $\S 170(\mathrm{~h})(5)$ (i.e., the conservation purpose of the easement was not "protected in perpetuity") in 2004.

In analyzing these issues, the Tax Court first reiterated the well settled rule that, "[i]n a Federal tax controversy, State law controls the determination of a taxpayer's interest in property while the tax consequences are determined under Federal law." Accordingly, New York law governed when the taxpayers' donation of the façade easement was regarded as complete, but Federal tax law determined the tax consequences. Because New York law provides that conservation easements in the state have no legal effect unless they are recorded, the court found that the façade easement was not effective until January 26, 2005. ${ }^{194}$ Unlike in Gorra, the façade easement in Zarlengo presumably was not delivered to the recording office in 2004 and thus, was not considered recorded in that year.

The Tax Court further explained that, even assuming the façade easement had been legally enforceable by NAT against the donors in 2004 because both parties signed the easement that year, the easement still would not have satisfied the perpetuity requirements in 2004 "because neither the use restriction nor the conservation purpose of the conservation easement was protected in perpetuity until January 26, 2005." The court explained that, if a buyer had purchased the subject townhouse and recorded the purchase deed before January 26, 2005, the buyer would have taken the townhouse free and clear of the conservation easement. Moreover, the possibility that this could have occurred was not so remote as to be negligible.

The Tax Court concluded that the donors in Zarlengo were not entitled to deductions on their 2004 returns because the perpetuity requirements were

\footnotetext{
${ }^{194}$ The Tax Court held similarly in Rothman I. See also Satullo (although decided on lack of mortgage subordination grounds, the Tax Court stated "Georgia law clearly provides that until an easement is recorded its intended property restrictions are legally unenforceable" and "although the Deed of Gift created an easement that was accepted by [the land trust] during December 1985, its terms were not enforceable as required by [Treas. Reg. $§ 1.170 \mathrm{~A}-14(\mathrm{~g})(1)]$ until January 19, 1988, when it was recorded").
} 
not satisfied in 2004, and it followed that the donors also were not entitled to carryover deductions on subsequent years' returns. However, the IRS had acknowledged that the easement could be considered "made in perpetuity" in 2005 for purposes of $\S 170(\mathrm{~h})(2)(\mathrm{C})$ and $\S 170(\mathrm{~h})(5)(\mathrm{A})$ because the easement was recorded in that year, and the Tax Court determined that "both the use restriction and the conservation purpose of the conservation easement were protected in perpetuity as of January 26, 2005." Accordingly, given that the other requirements of $\S 170(\mathrm{~h})$ and the substantiation requirements were satisfied, the donors' tax liability for 2005, 2006, and 2007 could be redetermined assuming the donation had been made in 2005 .

c. Mecox. Mecox involved a donation to NAT of a façade easement on a building in New York's Greenwich Village Historic District. The donor (the Mecox partnership) and NAT signed the easement in December 2004 and Mecox claimed a \$2.21 million deduction for the donation on its 2004 partnership tax return. However, the easement was not recorded until November 17, 2005, almost one year later. The IRS disallowed the claimed deduction in full, arguing that (i) the contribution was not made until 2005, the year in which the easement was recorded, and (ii) the appraisal was not timely because it was made more than 60 days before the date of the contribution. The U.S. District Court for the Southern District of New York held for the IRS on both counts.

As in Zarlengo and Rothman I, the District Court found that, as a matter of law, Mecox had not made a charitable contribution of the façade easement in 2004 because the easement was not effective under New York law until it was recorded in November 2005. The District Court further explained that, even if the court were to accept that the date the easement was contributed was the date of the delivery of the deed to NAT, the easement still did not satisfy $\S 170(\mathrm{~h})$ 's definition of a "qualified conservation contribution" until the easement was recorded in 2005 (i.e., the conservation purpose of the contribution was not "protected in perpetuity" and the underlying property was not "subject to legally enforceable restrictions" until 2005). Absent recordation, a purchaser of the property who recorded the purchase deed would take the property free of the easement.

Mecox argued that, because the easement did not specifically reference the New York conservation easement enabling statute, that statute did not apply and the easement was a common law restrictive covenant that does not require recordation to be effective. The court dismissed that argument, finding that there was "no question" that the easement fell under the New York enabling statute's definition of a conservation easement.

Failure to record the easement until November 2005 also rendered Mecox's appraisal untimely. The appraisal was dated June 13, 2005, and estimated 
the value of the easement as of November 1, 2004. The court found that the appraisal was "conducted" on June 13, 2005, but the easement was not "contributed" to NAT until it was recorded on November 17, 2005 (5 months later). Accordingly, the appraisal "took place" more than 60 days before the contribution date and thus, did not satisfy the timing requirement in Treasury Regulation $\S 1.170 \mathrm{~A}-13$ (c)(3)(i).

d. Ten Twenty Six Investors. Ten Twenty Six Investors also involved a donation to NAT of a façade easement on a building in New York City. The donor (a partnership) and a representative of NAT signed the easement in December 2004 and the partnership claimed a $\$ 11.3$ million deduction for the donation on its 2004 partnership tax return. However, the easement was not recorded until December 2006. The IRS disallowed the claimed deduction in full and the Tax Court sustained the disallowance.

The partnership in Ten Twenty Six Investors argued that Zarlengo, Rothman, and Mecox were wrongly decided. The Tax Court disagreed, holding that those closely analogous cases compelled the conclusion that the partnership was not entitled to a deduction in 2004 for the conveyance. However, "for the sake of completeness," the court addressed the partnership's key arguments in greater detail in the Ten Twenty Six Investors opinion and concluded that the perpetuity requirements of $\S 170(\mathrm{~h})(2)(\mathrm{C})$ and $\S 170(\mathrm{~h})$ (5)(A) were not met for 2004 because neither the use restriction nor the conservation purpose of the easement was protected in perpetuity as of the date of donation.

3. Finer Points of Delivery and Recording. In many jurisdictions, where the recording offices are backed up, a document may be delivered to the recording office in December but not recorded by the office staff until January or even later. As explained in the discussion of Gorra above, in some states, like New York, delivery to the recording office constitutes recording, but that may not be the rule in all states. In addition, many conservation easement deeds have an "effective date" provision that says the easement is effective when it is signed and recorded. Legal counsel to donors should consider whether it would be prudent to instead include a provision in an easement deed stating that the easement is effective when the deed is signed and "delivered for recording." In addition, the person who delivers the signed easement deed to the recording office should obtain a datestamped copy indicating the delivery date. At the very least, easement holders, donors, and their advisors should be aware of this issue.

\section{Quid Pro Quo.}

1. Treasury Regulation Requirements. A charitable contribution is not deductible if it is structured as a quid pro quo exchange. ${ }^{195}$ Treasury Regulation $\S 1.170 \mathrm{~A}-$ 14(h)(3)(i) provides:

${ }^{195}$ Hernandez v. Comm'r, 490 U.S. 680, 681 (1989) ("The legislative history of the 'contribution or gift' limitation reveals that Congress intended to differentiate between unrequited payments to qualified recipients, which are deductible, 
- If, as a result of the donation of a [conservation easement], the donor or a related person receives, or can reasonably expect to receive, financial or economic benefits that are greater than those that will inure to the general public from the transfer, no deduction is allowable under this section.

- However, if the donor or a related person receives, or can reasonably expect to receive, a financial or economic benefit that is substantial, but it is clearly shown that the benefit is less than the amount of the transfer, then a deduction under this section is allowable for the excess of the amount transferred over the amount of the financial or economic benefit received or reasonably expected to be received by the donor or the related person. ${ }^{196}$

\section{Case Law. Quid pro quo has been an issue in a number of cases.}

a. Pollard. In Pollard, the Tax Court sustained the IRS's disallowance of a deduction of more than $\$ 1$ million claimed with respect to a conservation easement conveyance because the conveyance was part of a quid pro quo exchange. The taxpayer had purchased a 67-acre parcel in Boulder County, Colorado, and had to obtain approval from the county to increase the property's building density. After public hearings, the board of county commissioners agreed to grant the taxpayer's subdivision exemption request, which allowed the property to be split into two residential lots, provided the taxpayer granted a conservation easement encumbering the property to the county.

The taxpayer in Pollard maintained that no quid pro quo arrangement existed, arguing, among other things, that approval of his subdivision

and payments made to such recipients with some expectation of a quid pro quo in terms of goods or services, which are not deductible."). See also Boone v. Comm'r, T.C. Memo 2013-101 (conveyance of fill to city not a deductible charitable contribution because taxpayer failed to meet its burden of proving that the fair market value of the fill exceeded the fair market value of the consideration received in exchange); Perlmutter v. Comm'r, 45 T.C. 311 (1965) (transfers of land to school districts and a recreation district in accordance with zoning regulations were not charitable contributions); Ottawa Silica Co. v. U.S., (Ct. Cl. Trial Div.), 49 A.F.T.R.2d 82-1162, 82-1 USTC P 9308 ("It is...quite apparent that plaintiff conveyed the land to the school district fully expecting that as a consequence of the construction of public access roads through its property it would receive substantial benefits in return"); Small, Real Estate Developers and Conservation Easements-Not as Simple as it Sounds, 19-JUN PROB. \& PROP. 24 (2005).

196 See Rev. Rul. 76-185, from which the Treasury Regulation language appears to be derived, and which provides that "payments made by the taxpayer for the restoration and maintenance of the historic mansion and its grounds are not deductible as charitable contributions...unless the taxpayer can establish that the payments exceed the monetary value of all benefits received or expected to be received." See also United States v. Amer. Bar Endowment, 477 U.S. 105 (1986) ("The sine qua non of a charitable contribution is a transfer of money or property without adequate consideration. The taxpayer, therefore, must at a minimum demonstrate that he purposely contributed money or property in excess of the value of any benefit he received in return."); Treas. Reg. $\S 1.170 \mathrm{~A}-1(\mathrm{~h})(1)$ ("No part of a payment that a taxpayer makes to or for the use of an organization described in section 170 (c) that is in consideration for...goods or services...is a contribution or gift within the meaning of section 170(c) unless the taxpayer-(i) Intends to make a payment in an amount that exceeds the fair market value of the goods or services; and (ii) Makes a payment in an amount that exceeds the fair market value of the goods or services."); Treas. Reg. § 1.170A-1(h)(2)(i) (“The charitable contribution deduction under section 170(a) for a payment a taxpayer makes partly in consideration for goods or services may not exceed the excess of - (A) The amount of any cash paid and the fair market value of any property (other than cash) transferred by the taxpayer to an organization described in section 170(c); over (B) The fair market value of the goods or services the organization provides in return."). 
exemption request had been "virtually guaranteed," that the land use code sections governing his exemption request did not require the grant of a conservation easement, and that all documents relating to the grant of the easement referred to it as a "gift." One of the county commissioners even wrote a letter to the taxpayer (apparently at the taxpayer's request in preparation for the Tax Court trial) stating that, to the best of his recollection, he did not require the taxpayer to grant the easement in exchange for the subdivision exemption.

The Tax Court was not persuaded. Based on its examination of the "external features of the transaction," the court found that the subdivision exemption request was far from being virtually guaranteed and, in fact, had little chance of being granted without the taxpayer's promise to grant the easement. ${ }^{197}$ The taxpayer also did not establish that the value of the easement he conveyed to the county exceeded the value of the subdivision exemption granted to him, or that he intended to make a charitable contribution. ${ }^{198}$

The Tax Court also sustained the IRS's imposition of an accuracy-related penalty in Pollard, finding that the taxpayer did not act with reasonable cause and in good faith in claiming the deduction. The evidence produced at trial, said the court, demonstrated that all of the parties involved understood that the easement was contributed for the express purpose of encouraging the county to grant the taxpayer a subdivision exemption, and it would be unreasonable for the court to believe that anyone involved in the transaction (i.e., the taxpayer, his advisers, or the county commissioners) believed there was an unrequited contribution.

b. Seventeen Seventy Sherman Street. In Seventeen Seventy Sherman Street, the Tax Court sustained the IRS's complete disallowance of an LLC's claimed \$7.15 million deduction for the conveyance of interior and exterior easements restricting the use of a shrine in Denver, Colorado, because the conveyance was part of a quid pro quo exchange. The shrine is listed on the National Register of Historic Places and as a historic landmark by the City and County of Denver. The LLC owned two properties on Sherman Streetthe shrine and a parking lot. Prior to granting the easements, the LLC and the City of Denver entered into a development agreement in which, among other things, the LLC agreed to convey the easements to Historic Denver and rehabilitate the shrine in exchange for certain zoning changes to the shrine and the parking lot.

\footnotetext{
${ }^{197}$ In ascertaining whether a given payment is a contribution or gift, or is made with the expectation of quid pro quo, the IRS and the courts examine "the external features of the transaction," thus avoiding the need to conduct an imprecise inquiry into the motivations of individual taxpayers. Hernandez v. Comm'r, 490 U.S. 680, 701-702 (1989).

198 See supra note 196 and accompanying text.
} 
The Tax Court's opinion detailed the following elements of a quid pro quo analysis in the charitable deduction context.

- A taxpayer's contribution is deductible 'only if and to the extent it exceeds the market value of the benefit received.'

- '[t]he sine qua non of a charitable contribution is a transfer of money or property without adequate consideration.'

- 'a charitable gift or contribution must be a payment made for detached and disinterested motives. This formulation is designed to ensure that the payor's primary purpose is to assist the charity and not to secure some benefit personal to the payor.'

- The consideration received by the taxpayer need not be financial. Medical, educational, scientific, religious, or other benefits can be consideration that vitiates charitable intent.

- In ascertaining whether a given payment was made with the expectation of anything in return, courts examine the external features of the transaction. This avoids the need to conduct an imprecise inquiry into the motivations of individual taxpayers.

- The taxpayer claiming a deduction must, at a minimum, demonstrate that "he purposely contributed money or property in excess of the value of any benefit he received in return."

- Thus, a taxpayer who receives goods or services in exchange for a contribution of property may still be entitled to a charitable deduction if the taxpayer (1) makes a contribution that exceeds the fair market value of the benefits received in exchange and (2) makes the excess payment with the intention of making a gift. ${ }^{199}$

- If the taxpayer satisfies these requirements, the taxpayer is entitled to a deduction not to exceed the fair market value of the property the taxpayer transferred less the fair market value of the goods or services received. ${ }^{200}$

The Tax Court explained that a quid pro quo analysis in the conservation easement donation context ordinarily consists of two parts-(1) valuation of the contributed conservation easement and then (2) valuation of the consideration received in exchange for the easement. The court explained, however, that when a taxpayer grants a conservation easement as part of a quid pro quo exchange and fails to identify or value all of the consideration received, the taxpayer is not entitled to a deduction because he failed to comply with $\S 170$ and the regulations. In such a case, it is unnecessary to determine either the value of the easement or whether the taxpayer made an excess payment with the intention of making a gift. The taxpayer's failure to identify or value all of the consideration received and, thus, to prove that

199 See id.

${ }^{200}$ See id. 
the value of the easement exceeded the value of the consideration is fatal to the deduction. ${ }^{201}$

The Tax Court determined that the LLC had received two types of consideration in exchange for its conveyance of the interior and exterior easements:

- a zoning change that eliminated authorization to develop residential condominium units within the shrine but also permitted development on the parking lot up to 650 feet, subject to a "view plane" restriction of 155 feet (a view plane restriction limits the height of buildings from a specified view point within Denver's city park and is meant to preserve the view of the Rocky Mountain Skyline from that view point), and

- the Denver Community Planning and Development Agency's recommendation to the Denver Planning Board to approve a view plane variance (which variance was ultimately approved).

On its 2003 tax return, however, the LLC claimed a \$7.15 million charitable deduction for its conveyance of the easements and made no adjustment for the consideration it received in exchange. At trial, the LLC conceded that it had received the zoning change in exchange for its conveyance of the easements and argued that its deduction should be reduced by just over $\$ 2$ million as a result. The LLC also asserted that the Planning and Development Agency's recommendation to the Planning Board to approve a view plane variance was either not consideration received in exchange for the grant of the easements, or was consideration but had no real value. The Tax Court disagreed, finding that the Agency's view-plane-variance recommendation was consideration and had substantial value. The court concluded that the LLC's failure to identify or value all of the consideration received, or to provide any credible evidence to permit the court to accurately value all of the consideration received, was fatal to the deduction.

Also notable is that the consideration the LLC received in exchange for its conveyance of the easements did not come from the donee, Historic Denver, but instead came from the City of Denver. The IRS argued that the LLC failed to substantiate its claimed deduction because it failed to (i) obtain a contemporaneous written acknowledgment (CWA) meeting the requirements of IRC $\S 170(\mathrm{f})(8)$ or (ii) disclose that the contribution was part of a bargain sale on Form 8283. The LLC argued that $\S 170(f)(8)$

\footnotetext{
${ }^{201}$ See also Cohan v. Comm'r, T.C. Memo. 2012-8, in which the Tax Court upheld the IRS's complete disallowance of a charitable income tax deduction claimed with respect to a bargain sale transaction because the contemporaneous written acknowledgment (CWA) that the donee provided to the donor did not include a description or good faith estimate of the total consideration provided to the donor, and the donor's reliance on the CWA was therefore unreasonable. The court explained that "the deterrence value of $\S 170(f)(8)$ 's total denial of a deduction comports with the effective administration of a self-assessment and self-reporting system."
} 
requires a donor to obtain a CWA providing a good-faith estimate of the value of the consideration received from the donee (i.e., Historic Denver), and it received no consideration from Historic Denver. The LLC also argued that the grant of the easements to Historic Denver was not a bargain sale because it received no consideration from Historic Denver and, thus, it was not required to report the conveyance as a bargain sale on the Form 8283 . The Tax Court found these contentions "dubious." The court noted that the grant of the easements was a complex negotiation among the LLC, the city, and Historic Denver, and Historic Denver's role was largely as the city's designee to hold the easements. The court thus generally found persuasive the IRS's argument that the consideration received should have been disclosed on the CWA and the Form 8283. However, because the court denied the deduction in full on quid pro quo grounds, it did not decide these substantiation issues.

The Tax Court also agreed with the IRS that the LLC was liable for the accuracy-related penalty because it acted negligently or in disregard of the requirements of $\S 170$ and the regulations. "Negligence," said the court, is strongly indicated where a taxpayer fails to make a reasonable attempt to ascertain the correctness of a deduction that would seem to a reasonable and prudent person to be "too good to be true." And a taxpayer acts with "disregard" when, among other things, he does not exercise reasonable diligence to determine the correctness of a return position. The LLC conveyed the easements as part of a quid pro quo exchange but reported the conveyance on its 2003 return as a charitable contribution without making any adjustment for the consideration it received in exchange. The court found that the LLC acted negligently or with disregard because it did not make a reasonable attempt to ascertain the correctness of the deduction.

The LLC argued that it was eligible for the reasonable cause and good faith exception to the penalty because it relied on professional advice. The Tax Court disagreed. Although the LLC had consulted with a tax attorney regarding the conveyance, that attorney testified at trial that he had advised the LLC that it had to reduce the value of its deduction by the consideration received in the quid pro quo exchange. The Tax Court noted that it would be unreasonable for the court to believe that at the time of the contribution or at the time of filing the LLC's return either the LLC or its advisers believed that the contribution of the easements was an unrequited contribution or that the consideration received had no value. Consequently, the LLC's disregard of the attorney's advice was not reasonable and in good faith, and the LLC could not rely on the professional advice of the attorney to negate the penalty.

c. Wendell Falls. In Wendell Falls I, the Tax Court sustained the IRS's disallowance of a $\$ 1.798$ million deduction claimed by the Wendell Falls Development, LLC, with regard to a conservation easement donation. The 
LLC owned 1,280 acres in Wake County, North Carolina, and planned to subdivide the land into a master-planned community with residential areas, commercial spaces, an elementary school, and a park. The LLC identified 125 of the 1,280 acres as the land upon which the park would be placed.

In mid-2005, the LLC and the county began discussions regarding the county's purchase of the 125 acres for use as a county park. Sometime after those discussions began, the LLC proposed placing a conservation easement on the 125 acres before the sale to restrict the 125 acres to park use. The LLC presumably wanted to be able to assure purchasers of the residential and commercial lots on the remaining land that the 125 acres would be permanently protected as a park. Throughout 2006, the LLC and the county discussed the restrictions the easement would include and which charitable organization would hold the easement.

In October 2006, the Town of Wendell approved the Planned Unit Development (PUD), which contemplated up to 4,000 residential lots and stated that 125 acres would be dedicated to the creation of a park. However, the 125 acres was "unaffected by the town's approval of the PUD" because, even though the 125 acres was described in the PUD, it was outside the boundaries of the town and therefore not subject to the town's zoning ordinances. The Tax Court noted that "[t]he PUD stated that Wendell Falls received no preferential zoning in exchange for setting aside the 125 acres for use as a park. This statement is consistent with the rest of the record."

In December 2006, the county and the LLC entered into a purchase agreement regarding the 125 acres. The purchase agreement stated that placing a mutually agreeable conservation easement on the land was a precondition to the sale. The purchase agreement was later revised to correct for some errors, and in June of 2007, the county reauthorized the purchase of the 125 acres for just over $\$ 3$ million, which was the appraised value of the 125 acres unrestricted by the easement (i.e., the "before" easement value of the 125 acres). In exchange for $\$ 3$ million, the LLC (i) conveyed a conservation easement on the 125 acres to a local land trust and (ii) conveyed the restricted fee to the county. Thus, it appears that the county paid the LLC for both the easement and the restricted fee, although the easement was conveyed to a third-party land trust.

The LLC then claimed a $\$ 1.8$ million deduction for its "donation" of the easement to the land trust based on an appraisal that asserted that the easement had a value of more than $\$ 4.8$ million (that is, the LLC claimed a deduction for the difference between an alleged $\$ 4.8$ million value for the easement and the $\$ 3$ million the LLC had received from the county). The LLC then later filed an amended return on which it claimed it was entitled to a deduction for full $\$ 4.8$ million and, at trial, its valuation expert asserted that the easement had a value of over $\$ 5.9$ million. 
The IRS argued, among other things, that the deduction should be disallowed because LLC expected a substantial benefit from the easement - namely that the prospect of a public park on the 125 acres would increase the value of the rest of the adjoining 1,280 acres owned by the LLC. The Tax Court agreed, explaining that (i) no deduction for a charitable contribution is allowed if the taxpayer expects a substantial benefit from the contribution, (ii) in assessing whether a taxpayer expected a substantial benefit, the court looks to the external features of the transaction, and (iii) the LLC did expect a substantial benefit from the easement because having the park as an amenity would increase the value of the lots on the LLC's adjoining land.

The Tax Court also held, in the alternative, that the easement had no value. The court explained that, as evidenced by the LLC's development plan for the 1,280 acres (which included the 125 acres), the best use of the 125 acres was as parkland in the midst of a master-planned community. The conservation easement therefore did not diminish the value of the 125 acres because it did not prevent it from being put to its best use. The court further explained that its answer would not change if the land valued before and after the easement were the entire contiguous parcel (the entire 1,280 acres). Using the 125 acres as a park would make the master-planned community more desirable and therefore increase the value of the residential and commercial lots the LLC intended to sell. Taking that enhancement into account, the court said, the total value of the 1,280 acres would be undiminished by the easement.

The LLC was not, however, found liable for a $20 \%$ penalty because it satisfied the reasonable cause and good faith exception. The court noted that the most important factor in determining reasonable cause and good faith is the extent of the taxpayer's effort to ascertain the proper tax treatment of the transaction in question. As to the value of the easement, the LLC had retained two different state-certified real estate appraisers to appraise the easement. Although neither appraiser correctly accounted for the enhancement conferred by the easement on the unencumbered property, neither did the IRS's trial expert. Thus, the court held that " $[\mathrm{u}]$ nder the narrow circumstances of this case," there was reasonable cause for reporting the deduction and the deduction was reported in good faith.

In Wendell Falls II, the Tax Court denied the LLC's motion for reconsideration and supplemented its first opinion.

d. Costello. In Costello, taxpayers conveyed a conservation easement to Howard County, Maryland, in exchange for the right to sell 16 development rights to a developer pursuant to the county's transfer of development rights program. The right to sell the development rights was conditioned on the conveyance of the easement, which prohibited any future development of 
the subject property. In filing their tax return and claiming a deduction for the conveyance of the easement, the taxpayers failed to indicate that they had received the right to sell the development rights (and $\$ 2.5$ million on their sale) as a result of the conveyance. The Tax Court held that, even if the taxpayers had complied with the qualified appraisal and appraisal summary requirements (which they did not), the court would nonetheless disallow the deduction because the easement was conveyed as part of a quid pro quo exchange.

The taxpayers argued that easement's value exceeded the \$2.5 million of consideration they received in exchange for its conveyance (in the form of proceeds from their sale of the 16 development rights). The Tax Court dismissed that argument because (i) the taxpayers failed to provide evidence that the property could have been developed into more than 16 lots and (ii) the taxpayers could not sell the 16 development rights until they had placed the easement on the property and, once they did, all future development was prohibited, so there was no "excess" development potential that they could have contributed to the county in the form of a bargain sale.

The Tax Court sustained the IRS's imposition of accuracy-related penalties in Costello, explaining, in part, that the taxpayers "knew or reasonably should have known" that the sale of the development rights for \$2.5 million was relevant in determining any deduction to which they might be entitled.

e. McGrady. In McGrady, the taxpayers donated a conservation easement on their 25-acre homestead property to a Bucks County, Pennsylvania, Township, and fee-title to an adjacent 20 -acres to a local nonprofit. The taxpayers claimed a $\$ 2.35$ million deduction for each donation. The conveyances were components of a complex conservation transaction involving the taxpayers' property and neighboring property, and the parties involved included the Township, the local nonprofit, the owners of the neighboring property, and a local developer.

The IRS disallowed the deductions, claiming that the donations were made as part of a quid pro quo transaction. The IRS argued that the donations were components of a conservation transaction that benefited the taxpayers by reducing development on the neighboring property and ensuring that much of that property was conserved, thus protecting the taxpayers' privacy and views. The Tax Court rejected that argument, finding that neither the grant of the easement nor the conveyance of the 20 -acre parcel was conditioned on the Township or nonprofit supplying any return benefit to the taxpayers. The court held that the taxpayers were mere "incidental beneficiaries" of the overall conservation transaction, and neither the nonprofit, the Township, nor the developer intended to benefit the taxpayers. 
The court, however, reduced the allowable deductions for the donations of the 20-acre parcel and the conservation easement to $\$ 2.19$ million and $\$ 1.49$ million respectively, and further reduced those deductions by $\$ 29,000$ for an access easement the taxpayers received as part of the overall conservation transaction. Although the taxpayers had an informal access agreement with the owners of the neighboring property, they received a recorded access easement as part of the overall transaction, and the court found that the access easement constituted a return benefit that had to be valued and reduce the amount of the taxpayer's charitable contributions.

The value of the conservation easement reported on the taxpayer's return ( $\$ 2.35$ million) exceeded $150 \%$ of the value that the court determined to be correct (\$1.49 million) and, thus, constituted a substantial valuation misstatement. The taxpayers were not liable for valuation or other penalties, however, because they met the reasonable cause and good faith exceptions.

f. Pesky. In Pesky, the IRS asserted not only that the taxpayer's conveyance of a conservation easement was made in exchange for a quid pro quo, but also that the taxpayer was liable for a civil fraud penalty under IRC $\S 6663$. Section 6663 imposes a $75 \%$ penalty on tax underpayments due to fraud. Fraud is defined as an "intentional wrongdoing on the part of the taxpayer with the specific intent to avoid a tax known to be owing." The government must prove fraud by clear and convincing evidence, but intent can be inferred from strong circumstantial evidence.

After a review of the facts and circumstances surrounding the easement conveyance, the District Court was unable to conclude that a reasonable jury could find it "highly likely" that the taxpayer's deduction was due to fraud. Because the government did not produce sufficient evidence to meet its burden of showing fraud by clear and convincing evidence, the court granted the taxpayer's motion for summary judgment on the issue. The court determined, however, that other issues could not be resolved on summary judgment, including whether the conveyance of the easement was made in exchange for quid pro quo and whether the taxpayer obtained a contemporaneous written acknowledgment accurately reflecting any goods and services provided by the donee in exchange for the contribution. The parties in Pesky appear to have settled the case after the District Court rejected the fraud claim.

E. Side Agreements. In Graev I, the Tax Court sustained the IRS's disallowance of deductions claimed with regard to the donation to the National Architectural Trust (NAT) of both a façade easement valued at $\$ 990,000$ and an accompanying $\$ 99,000$ cash contribution. NAT had written a side letter to Mr. Graev, the donor, promising that, if the deduction for the easement were disallowed, NAT would "promptly refund [Mr. Graev's] entire cash endowment contribution and join with [him] to immediately remove the facade conservation easement from the property's title." The Tax Court disallowed the deductions 
for both the easement and cash contributions because the gifts were conditional and, at the time they were made, the possibility they would be defeated was not so remote as to be negligible.

Section 170 and the corresponding Treasury Regulations provide instructions and limitations that, at least in part, ensure that a donor will be able to deduct no more than what the donee actually receives. Three such limitations effectively provide that no deduction for a charitable contribution will be allowed unless, on the date of the contribution, the possibility that the donee's interest in the contribution will be defeated is "so remote as to be negligible." Those limitations are found in Treasury Regulations $\S$ $1.170 \mathrm{~A}-1$ (e) (pertaining to conditional gifts), $\S 1.170 \mathrm{~A}-7$ (pertaining to partial interest gifts), and $\S 1.170 \mathrm{~A}-14(\mathrm{~g})(3)$ (pertaining to gifts of conservation easements).

Based on the facts in Graev I, the court found that, on the date of the contributions, the possibility that the IRS would disallow the easement deduction and NAT would return the cash to Mr. Graev and remove the easement (i.e., that the gifts would be defeated) was not so remote as to be negligible. The facts the court found persuasive included the IRS's announced intention to scrutinize deductions for facade easement donations; Mr. Graev's insistence that NAT issue the side letter; NAT's practice of issuing side letters, the very essence of which "implies a non-negligible risk;" the enforceability of the side letter under state law; and NAT's incentive to honor its promises in the side letter so as not to impair its ability to obtain future contributions.

The possibility that a gift will be defeated will be considered so remote as to be negligible only if it is "so highly improbable that one might ignore it with reasonable safety in undertaking a serious business transaction" or "so highly improbable and remote as to be lacking in reason and substance." 202 In Graev I, the court explained: "the mere fact that he required the side letter is strong evidence that, at the time of Mr. Graev's contribution, the risk that his corresponding deductions might be disallowed could not be (and was not) 'ignored with reasonable safety in undertaking a serious business transaction." Obtaining the side letter also indicated that Mr. Graev did not think the chance of disallowance was "so highly improbable and remote as to be lacking in reason and substance." Accordingly, the mere fact of obtaining a side letter such as that at issue in Graev I may be a tripwire that destroys deductibility.

F. Donation by Term-Limited Lessee. In Harbor Lofts, the Tax Court held that the Harbor Lofts partnership, which leased two buildings from a Massachusetts public corporation for a term of years, was not entitled to a deduction for a façade easement on the buildings that Harbor Lofts and the corporation jointly conveyed to a historic preservation nonprofit. Harbor Lofts claimed a \$4,457,515 deduction for the donation, presumably because the owner of the building, the Massachusetts public corporation, which is a nonprofit corporation established under state law, could not benefit from the deduction.

${ }^{202}$ See Briggs v. Comm'r, 72 T.C. 646, 656-57 (1979). 
Harbor Lofts argued, among other things, that $\S 170(\mathrm{~h})(2)(\mathrm{C})$ does not explicitly require that an easement donor own the real property that is subject to the easement and that multiple parties, such as tenants in common, may join together in granting an easement. The IRS argued that Harbor Lofts, as a "time-limited" lessee, did not have a perpetual interest to give and that a time-limited leasehold interest could not be equated to the fee interest of a tenant in common.

In agreeing with the IRS, the Tax Court explained that:

(i) state law determines the nature of property rights, whereas federal law determines the appropriate tax treatment of those rights, and under Massachusetts law, a term-of-years leasehold interest constitutes personal property,

(ii) Harbor Lofts was not a tenant in common and the limited duration of a leasehold interest is far different from fee ownership as a tenant in common,

(iii) Harbor Lofts did not hold perpetual property rights in the buildings, so it was not possible for it to contribute a perpetual restriction on the use of the buildings as required by $\S 170(\mathrm{~h})(2)(\mathrm{C})$,

(iv) while $\S 170(\mathrm{~h})$ does not specifically require that an easement donor hold a fee interest, only the holder of a fee interest is able to grant a perpetual conservation restriction,

(v) when Harbor Lofts joined in the grant of the easement, it gave up contractual rights under the lease agreement, which are personal property rights, and a charitable contribution of a personal property right is not a "qualified real property interest" under $\S 170(\mathrm{~h})(2)(\mathrm{C})$,

(vi) while Harbor Lofts gave up something of value when it joined in the grant of the easement (the rights it held under the lease contract to make certain improvements or alterations to the buildings), it ceded those rights to the Massachusetts public corporation, not the holder of the easement,

(vii) even if Harbor Lofts were deemed to hold equitable ownership interests in the buildings as a result of the long-term lease, those interests would be for only a finite period and could not satisfy the perpetuity requirements of $\S 170(\mathrm{~h})$, and

(viii) as a time-limited lessee, Harbor Lofts did not have the power to impose perpetual restrictions on the buildings - it could not give what it did not have - and, thus, it could not protect the conservation purpose in perpetuity.

The Harbor Lofts opinion raises a number of questions. For example, could the holder of a life estate and the holder of the remainder interest in real property jointly donate a conservation easement on the property and share the deduction based on the value of their respective interests? Or is the owner of a life estate, which is effectively a term-limited interest, prevented from granting a perpetual use restriction? What if a long-term lessee and the owner of the fee contribute their interests to a partnership, the partnership donates an easement, and the partnership allocates the entire resulting deduction to the lessee? If a term-limited lessee like Harbor Lofts were deemed to have a sufficient interest in the real property to claim a deduction, would other parties with limited interests similarly be entitled to claim a deduction, such as a lender holding an outstanding mortgage on the property? Or is the answer that any party holding an interest that is not an undivided portion of the entire fee must agree to subordinate its interest to the easement for the easement to 
qualify for the deduction, but the deduction can be claimed only by the owner (or owners) of undivided portions of the fee (like the sole owner of the fee or tenants in common)?

G. "Qualified Farmer or Rancher." Pursuant to IRC $\S 170(\mathrm{~b})(1)$, an individual can generally claim the deduction generated by a conservation easement donation to the extent of $50 \%$ of the individual's adjusted gross income (AGI) in each of the year of the donation and the following fifteen years. However, an individual who is a "qualified farmer or rancher" can deduct the value of the donation to the extent of $100 \%$ of his or her AGI in each of the year of the donation and the following fifteen years. A "qualified farmer or rancher" is an individual whose gross income from the trade or business of farming (within the meaning of IRC $\S 2032 \mathrm{~A}(\mathrm{e})(5))$ is greater than $50 \%$ of the individual's gross income for the taxable year. ${ }^{203}$

In Rutkoske, two brothers who ran a complex farming operation involving multiple entities claimed that they were qualified farmers or ranchers and, thus, eligible to benefit from the $100 \%$ of AGI deduction provision with regard to the donation component of the bargainsale of a conservation easement by an LLC in which they each owned a $50 \%$ interest. The Tax Court disagreed, finding that neither brother had gross income from the trade or business of farming greater than $50 \%$ of his gross income for the taxable year on two grounds.

1. Neither the sale of land nor the bargain sale of a conservation easement are activities listed in $\S 2032 \mathrm{~A}(\mathrm{e})(5)$. Accordingly, the proceeds from such sales, which flowed through the LLC to the brothers for the taxable year, did not constitute "income from the trade or business of farming."

2. If a partnership is not in the trade or business of farming, income or gain flowing through the partnership to the partners does not constitute "income from the trade or business of farming." In Rutkoske, the LLC was not in the business of farming; it was in the business of leasing real estate. Thus, the income from the LLC that flowed through to the Rutkoske brothers did not constitute income from the trade or business of farming.

The court acknowledged that the statutory rules make it difficult for a farmer to receive the maximum charitable contribution deduction if the farmer sells property in a year in which he donates a conservation easement, especially in a state with high land values. However, the court explained that it is not its task to rewrite statutes, and "being a farmer does not make one a "qualified farmer"' for purposes of the $100 \%$ of AGI deduction rule.

H. Disguised Sales. In each of SWF Real Estate, LLC, and Route 231, LLC v. Comm'r, 810 F.3d 247 ( $4^{\text {th }}$ Cir. 2016), the IRS successfully invoked a tax avoidance principle - the "disguised sales" rules under IRC $\S 707$ - to attack the special allocation of state income tax credits generated by a partnership's donation of a conservation easement. The courts held that each partnership's transfer to a $1 \%$ partner of more than $90 \%$ of the state income

${ }^{203}$ For guidance on deductions by individuals for qualified conservation contributions, including farmers and ranchers, see IRS Notice 2007-50. 
tax credits generated by the donation was a taxable disguised sale. In Route 231, LLC, the Fourth Circuit explained that $\S 707$ "prevents use of the partnership provisions to render nontaxable what would in substance have been a taxable exchange if it had not been "run through' the partnership."

In Bosque Canyon Ranch I, the Tax Court held that two partnerships' transfers of 5-acre homesites on a shared-amenities ranch to limited partners in exchange for purported "capital contributions" were, in fact, taxable disguised sales. The court found that the distributions of the 5-acre homesites to the limited partners were made in exchange for the limited partners' payments and were not subject to the entrepreneurial risks of the partnerships' operations. Accordingly, the court held that the partnerships were required to recognize and include in their gross income any gains relating to the disguised sales. In Bosque Canyon Ranch II, however, the Fifth Circuit vacated the Tax Court's determination that the entirety of the limited partners' contributions were disguised sales and remanded for that court to determine the correct amount of any taxable income that resulted from the disguised sales.

I. PLRs Recommending Revocation of Tax-Exempt Status. ${ }^{204}$ The IRS has issued a number of Private Letter Rulings (PLRs) recommending revocation of the tax-exempt status of organizations holding conservation easements based on fairly egregious facts. ${ }^{205}$ These PLRs illustrate some of the issues the IRS has focused on when examining organizations that accept and hold conservation easements.

1. Although the PLRs are impossible to accurately summarize in an outline because of their highly fact specific nature, some of the problems noted in the PLRs include:

- the organization served as a vehicle for its founder, the founder's family, or other related parties to donate conservation easements and claim deductions;

- the easements donated to the organization did not satisfy the conservation purpose test under $\S 170(\mathrm{~h})(4)$ (e.g., the preservation was not pursuant to a clearly delineated government conservation policy; the easement encumbered ordinary farmland with no unique features like native plants, trees, or animals; or the easement encumbered land in a gated condominium tennis resort and contained a private miniature golf course used for the pleasure of the residents only);

- the organization did not take steps to ensure that the easements it accepts serve a conservation purpose (e.g., the organization's officers, trustees, and employees did not have backgrounds or expertise in botany, biology, ecological sciences, or other fields that would enable them to credibly process or evaluate the property, or no baselines were obtained or consisted

\footnotetext{
${ }^{204}$ See supra note 116 for a description of Private Letter Rulings.

205 See, e.g., PLR 201044026; PLR 201048045; PLR 201109030; PLR 201110020; PLR 201405018. See also PLR 201234029 (organization created for the purpose of carrying on a for-profit hay farm on property that is not ecologically significant or open to the public is not operated for an exempt purpose).
} 
of one page or one paragraph reports; or the organization was unaware of the extensive retained rights in the easements it accepted);

- the organization did not monitor the easements it accepted on a regular basis (or at all), did not have the commitment to protect the conservation purposes (if any) of the donations, and did not have the resources to enforce the easements should enforcement become necessary;

- there was no one associated with the organization that had any formal education, training, or expertise in conservation matters;

- the organization allowed one of its easement-encumbered properties to be damaged by illegal dumping and vehicles, and another, located in an exclusive small waterfront residential development, to be encroached upon by the residents who constructed, among other things, large ponds and a boat and recreational vehicle storage facility for the exclusive use of the residents;

- the organization amended a conservation easement to allow additional development for a fee;

- the easements the organization acquired violated the perpetuity requirement under $\S 170(\mathrm{~h})$ because the organization had the right to terminate the easements;

- the organization did not develop or sponsor any educational events, solicit the general public for support, or appear to hold itself out to the public as a charitable conservation organization; and

- the organization was not operated in accordance with its bylaws (e.g., there were no meetings of officers or board members, no elections, and no internal controls, and there was only the bare minimum with regard to records and recordkeeping).

2. PLR 201048045 explains:

To establish that it operates exclusively for charitable conservation purposes under section 501(c)(3), an organization must do more than merely accept and hold easements for which donors are claiming charitable contribution deductions under section 170(h). The organization must establish that any accepted easements actually serve a conservation purpose. The organization must also operate as an effective steward to ensure that the easement continues to further a conservation purpose. The easement is a set of legal rights. It can serve conservation purposes only if enforced where necessary. The need for enforcement can be determined only through monitoring. The extent of an organization's due diligence and monitoring activities, combined with its capacity for and commitment to enforcement when necessary, becomes highly significant in determining whether accepting and holding easements actually furthers a charitable conservation purpose and thus whether an organization with the primary purpose of accepting and holding easements qualifies for exemption under section 501(c)(3).

3. The IRS Conservation Easement Audit Techniques Guide notes: 
A "self-serving" donee organization organized solely for the purpose of accepting one easement may lack charitable purpose or be engaged in selfdealing. If there is a question or concern as to the operations of the organization, examiners should submit a referral to Tax Exempt and Governmental Entities (TEGE). ${ }^{206}$

The Guide also provides that an IRS examiner should:

Ask for the [donee] organization's monitoring reports to verify whether the taxpayer is in compliance with, and the donee organization is enforcing, the terms of the easement. In some cases, donee organizations have allowed changes that were in violation of the terms of the easement.

Examiners should consult Counsel for assistance if the easement was terminated or not being enforced. In addition, a referral to TEGE should be considered. ${ }^{207}$

J. State Tax Credits. A number of states offer state income tax credits to donors of conservation easements and several cases have addressed issues relating to such credits.

Esgar involved three taxpayers, each of whom donated a conservation easement on land located in Colorado, received transferable income tax credits from Colorado as a result of the donation, and sold a portion of the credits to third parties within two weeks. The taxpayers reported the proceeds from the credit sales as long-term capital gain, short-term capital gain, and ordinary income, respectively. After an audit of the taxpayers' income tax returns, the IRS determined that the proceeds from the sales of the credits should have been reported as ordinary income.

In Tempel v. Comm'r, 136 T.C. 341 (2011), the Tax Court held that the taxpayers' state tax credits were zero-basis capital assets and, given the short holding periods, income from the sale of such credits was short-term capital gain. Several months later, the IRS released a Chief Counsel Advice that addresses the tax consequences of the sale of state tax credits to both the seller and the buyer. ${ }^{208}$

The taxpayers appealed both Esgar I (in which the Tax Court held that the taxpayers had substantially overvalued the conservation easements) and Tempel to the Tenth Circuit. In Esgar II, the taxpayers argued that their state tax credits, which they held for only about two weeks, were nonetheless long-term capital assets because they held the underlying real properties for longer than one year, they relinquished development rights in those properties through the donation of the easements, and they received the tax credits because of the donations. The Tenth Circuit disagreed, noting that the Tax Court correctly concluded in Tempel that the taxpayers had no property rights in the tax credits until the easement donations were complete and the credits were granted, and the credits never were,

\footnotetext{
206 See IRS Conservation Easement Audit Techniques Guide, supra note 23, at 57.

${ }^{207}$ See id., at 71.

${ }^{208}$ Chief Counsel Advice 201147024, available at http://www.irs.gov/pub/irs-wd/1147024.pdf.
} 
nor did they become, part of the taxpayers' real property rights. The Tenth Circuit also agreed with the Tax Court that the taxpayers' holding period in the credits began at the time the credits were granted and ended when taxpayers sold them, and since the taxpayers sold the credits in the same month in which they received them, the gains from the sale of the credits were short-term capital gains.

The Tenth Circuit also summarily rejected the argument that the transactions amounted to some sort of like-kind exchange of conservation easements for tax credits that might result in the "tacking" of holding periods. The court further noted that if these were like-kind exchanges it would negate the charitable nature of the taxpayers' contributions of the easements.

As noted in Part III.H above, in each of SWF Real Estate, LLC, and Route 231, LLC v. Comm'r, 810 F.3d 247 ( $4^{\text {th }}$ Cir. 2016), the IRS successfully invoked the "disguised sales" rules under $\S 707$ to attack the nonpro rata allocation of state income tax credits generated by a partnership's donation of a conservation easement. 
Appendix A

Internal Revenue Code $\S 170(\mathrm{~h})$

\section{(h) Qualified conservation contribution.}

(1) In general. For purposes of subsection (f)(3)(B)(iii), the term "qualified conservation contribution" means a contribution--

(A) of a qualified real property interest,

(B) to a qualified organization,

(C) exclusively for conservation purposes.

(2) Qualified real property interest. For purposes of this subsection, the term "qualified real property interest" means any of the following interests in real property:

(A) the entire interest of the donor other than a qualified mineral interest,

(B) a remainder interest, and

(C) a restriction (granted in perpetuity) on the use which may be made of the real property.

(3) Qualified organization. For purposes of paragraph (1), the term "qualified organization" means an organization which--

$(A)$ is described in clause (v) or (vi) of subsection (b)(1)(A), or

(B) is described in section 501(c)(3) [IRC Sec. 501(c)(3)] and--

(i) meets the requirements of section 509(a)(2) [IRC Sec.

509(a)(2)], or

(ii) meets the requirements of section 509(a)(3) [IRC Sec. 509(a)(3)] and is controlled by an organization described in subparagraph $(A)$ or in clause (i) of this subparagraph.

(4) Conservation purpose defined.

(A) In general. For purposes of this subsection, the term "conservation purpose" means--

(i) the preservation of land areas for outdoor recreation by, or the education of, the general public,

(ii) the protection of a relatively natural habitat of fish, wildlife, or plants, or similar ecosystem,

(iii) the preservation of open space (including farmland and forest land) where such preservation is--

(I) for the scenic enjoyment of the general public, or

(II) pursuant to a clearly delineated Federal, State, or local governmental conservation policy,

and will yield a significant public benefit, or

(iv) the preservation of an historically important land area or a certified historic structure. 
(B) Special rules with respect to buildings in registered historic districts. In the case of any contribution of a qualified real property interest which is a restriction with respect to the exterior of a building described in subparagraph (C)(ii), such contribution shall not be considered to be exclusively for conservation purposes unless--

(i) such interest--

(I) includes a restriction which preserves the entire exterior of the building (including the front, sides, rear, and height of the building), and

(II) prohibits any change in the exterior of the building which is inconsistent with the historical character of such exterior,

(ii) the donor and donee enter into a written agreement certifying, under penalty of perjury, that the donee--

(I) is a qualified organization (as defined in paragraph (3)) with a purpose of environmental protection, land conservation, open space preservation, or historic preservation, and (II) has the resources to manage and enforce the restriction and a commitment to do so, and

(iii) in the case of any contribution made in a taxable year beginning after the date of the enactment of this subparagraph [Aug. 17, 2006], the taxpayer includes with the taxpayer's return for the taxable year of the contribution--

(I) a qualified appraisal (within the meaning of subsection (f)(11)(E)) of the qualified property interest,

(II) photographs of the entire exterior of the building, and (III) a description of all restrictions on the development of the building.

(C) Certified historic structure. For purposes of subparagraph (A)(iv), the term "certified historic structure" means--

(i) any building, structure, or land area which is listed in the National Register, or

(ii) any building which is located in a registered historic district (as defined in section 47 (C)(3)(B) and is certified by the Secretary of the Interior to the Secretary as being of historic significance to the district.

A building, structure, or land area satisfies the preceding sentence if it satisfies such sentence either at the time of the transfer or on the due date (including extensions) for filing the transferor's return under this chapter for the taxable year in which the transfer is made. 
(5) Exclusively for conservation purposes. For purposes of this subsection-(A) Conservation purpose must be protected. A contribution shall not be treated as exclusively for conservation purposes unless the conservation purpose is protected in perpetuity.

(B) No surface mining permitted.

(i) In general. Except as provided in clause (ii), in the case of a contribution of any interest where there is a retention of a qualified mineral interest, subparagraph (A) shall not be treated as met if at any time there may be extraction or removal of minerals by any surface mining method.

(ii) Special rule. With respect to any contribution of property in which the ownership of the surface estate and mineral interests has been and remains separated, subparagraph (A) shall be treated as met if the probability of surface mining occurring on such property is so remote as to be negligible.

(6) Qualified mineral interest. For purposes of this subsection, the term "qualified mineral interest" means--

(A) subsurface oil, gas, or other minerals, and

(B) the right to access to such minerals 


\section{Appendix B}

\section{Treasury Regulation §1.170A-14}

\section{$\S$ 1.170A-14 Qualified Conservation Contributions.}

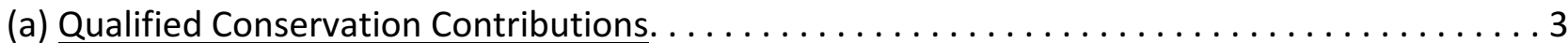

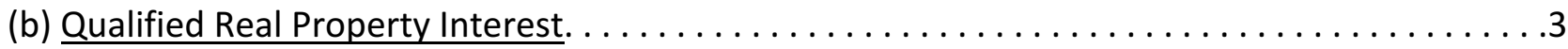

(1) Entire interest of donor other than qualified mineral interest

(2) Perpetual conservation restriction

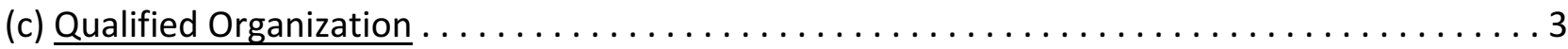

(1) Eligible donee

(2) Transfers by donee

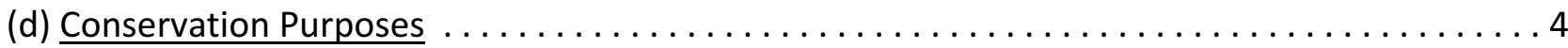

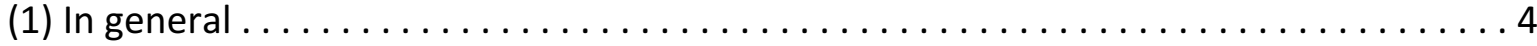

(2) Recreation or education $\ldots \ldots \ldots \ldots \ldots \ldots \ldots \ldots \ldots \ldots \ldots \ldots \ldots \ldots \ldots$

(i) In general

(ii) Access

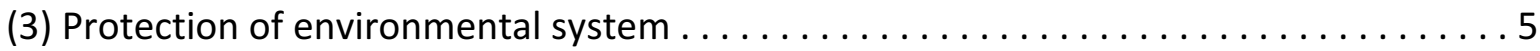

(i) In general

(ii) Significant habitat or ecosystem

(iii) Access

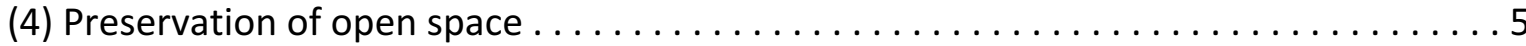

(i) In general

(ii) Scenic enjoyment
(A) Factors
(B) Access

(iii) Governmental conservation policy
(A) In general
(B) Effect of acceptance by governmental agency
(C) Access

(iv) Significant public benefit
(A) Factors
(B) Illustrations

(v) Limitation

(vi) Relationship of requirements

(A) Clearly delineated governmental policy and significant public benefit

(B) Scenic enjoyment and significant public benefit

(C) Donations may satisfy more than one test

(5) Historic preservation. .

(i) In general

(ii) Historically important land area

(iii) Certified historic structure 
(iv) Access

(v) Examples

(e) Exclusively for Conservation Purposes $\ldots \ldots \ldots \ldots \ldots \ldots \ldots \ldots \ldots \ldots \ldots \ldots \ldots \ldots$

(1) In general

(2) Inconsistent use

(3) Inconsistent use permitted

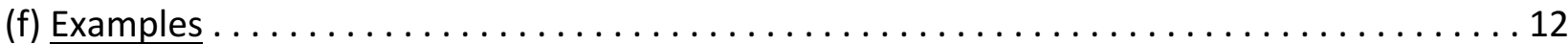

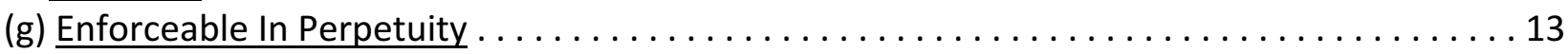

(1) In general

(2) Protection of a conservation purpose in case of donation of property subject to a mortgage

(3) Remote future event

(4) Retention of qualified mineral interest

(i) In general

(ii) Exception for qualified conservation contributions after July 1984

(iii) Examples

(5) Protection of conservation purpose where taxpayer reserves certain rights

(i) Documentation

(ii) Donee's right to inspection and legal remedies

(6) Extinguishment

(i) In general

(ii) Proceeds

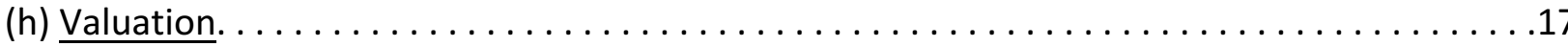

(1) Entire interest of donor other than qualified mineral interest

(2) Remainder interest in real property

(3) Perpetual conservation restriction

(i) In general

(ii) Fair market value of property before and after restriction

(iii) Allocation of basis

(4) Examples

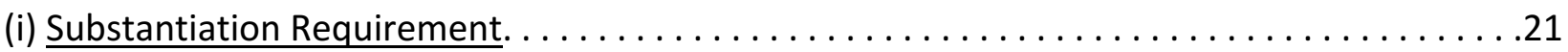

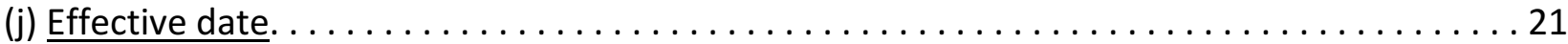




\section{$\underline{\S 1.170 A-14 \text { Qualified conservation contributions. }}$}

(a) Qualified conservation contributions. A deduction under section 170 is generally not allowed for a charitable contribution of any interest in property that consists of less than the donor's entire interest in the property other than certain transfers in trust (see $\S 1.170 \mathrm{~A}-6$ relating to charitable contributions in trust and $\S 1.170 \mathrm{~A}-7$ relating to contributions not in trust of partial interests in property). However, a deduction may be allowed under section $170(f)(3)(B)(i i i)$ for the value of a qualified conservation contribution if the requirements of this section are met. $A$ qualified conservation contribution is the contribution of a qualified real property interest to a qualified organization exclusively for conservation purposes. To be eligible for a deduction under this section, the conservation purpose must be protected in perpetuity.

(b) Qualified real property interest -- (1) Entire interest of donor other than qualified mineral interest. (i) The entire interest of the donor other than a qualified mineral interest is a qualified real property interest. A qualified mineral interest is the donor's interest in subsurface oil, gas, or other minerals and the right of access to such minerals.

(ii) A real property interest shall not be treated as an entire interest other than a qualified mineral interest by reason of section $170(h)(2)(A)$ and this paragraph $(b)(1)$ if the property in which the donor's interest exists was divided prior to the contribution in order to enable the donor to retain control of more than a qualified mineral interest or to reduce the real property interest donated. See Treasury regulations $\S 1.170 A-7(a)(2)(i)$. An entire interest in real property may consist of an undivided interest in the property. But see section $170(\mathrm{~h})(5)(\mathrm{A})$ and the regulations thereunder (relating to the requirement that the conservation purpose which is the subject of the donation must be protected in perpetuity). Minor interests, such as rights-of-way, that will not interfere with the conservation purposes of the donation, may be transferred prior to the conservation contribution without affecting the treatment of a property interest as a qualified real property interest under this paragraph (b)(1).

(2) Perpetual conservation restriction. A "perpetual conservation restriction" is a qualified real property interest. A "perpetual conservation restriction" is a restriction granted in perpetuity on the use which may be made of real property -- including, an easement or other interest in real property that under state law has attributes similar to an easement (e.g., a restrictive covenant or equitable servitude). For purposes of this section, the terms easement, conservation restriction, and perpetual conservation restriction have the same meaning. The definition of perpetual conservation restriction under this paragraph $(b)(2)$ is not intended to preclude the deductibility of a donation of affirmative rights to use a land or water area under $\S 1.170 \mathrm{~A}-13(\mathrm{~d})(2)$. Any rights reserved by the donor in the donation of a perpetual conservation restriction must conform to the requirements of this section. See e.g., paragraph (d)(4)(ii), (d)(5)(i), (e)(3), and (g)(4) of this section.

(c) Qualified organization -- (1) Eligible donee. To be considered an eligible donee under this section, an organization must be a qualified organization, have a commitment to protect the conservation purposes of the donation, and have the resources to enforce the restrictions. A conservation group organized or operated primarily or substantially for one of the conservation purposes specified in section $170(\mathrm{~h})(4)(A)$ will be considered to have the commitment required by the preceding sentence. A qualified organization need not set aside funds to enforce the 
restrictions that are the subject of the contribution. For purposes of this section, the term qualified organization means:

(i) A governmental unit described in section $170(b)(1)(A)(v)$;

(ii) An organization described in section 170(b)(1)(A)(vi);

(iii) A charitable organization described in section 501 (c)(3) that meets the public support test of section $509(a)(2)$;

(iv) A charitable organization described in section 501(c)(3) that meets the requirements of section 509(a)(3) and is controlled by an organization described in paragraphs (c)(1) (i), (ii), or (iii) of this section.

(2) Transfers by donee. A deduction shall be allowed for a contribution under this section only if in the instrument of conveyance the donor prohibits the donee from subsequently transferring the easement (or, in the case of a remainder interest or the reservation of a qualified mineral interest, the property), whether or not for consideration, unless the donee organization, as a condition of the subsequent transfer, requires that the conservation purposes which the contribution was originally intended to advance continue to be carried out. Moreover, subsequent transfers must be restricted to organizations qualifying, at the time of the subsequent transfer, as an eligible donee under paragraph (c)(1) of this section. When a later unexpected change in the conditions surrounding the property that is the subject of a donation under paragraph (b)(1), (2), or (3) of this section makes impossible or impractical the continued use of the property for conservation purposes, the requirement of this paragraph will be met if the property is sold or exchanged and any proceeds are used by the donee organization in a manner consistent with the conservation purposes of the original contribution. In the case of a donation under paragraph (b)(3) of this section to which the preceding sentence applies, see also paragraph (g)(5)(ii) of this section.

(d) Conservation purposes -- (1) In general. For purposes of section $170(\mathrm{~h})$ and this section, the term conservation purposes means --

(i) The preservation of land areas for outdoor recreation by, or the education of, the general public, within the meaning of paragraph $(d)(2)$ of this section,

(ii) The protection of a relatively natural habitat of fish, wildlife, or plants, or similar ecosystem, within the meaning of paragraph $(d)(3)$ of this section,

(iii) The preservation of certain open space (including farmland and forest land) within the meaning of paragraph $(d)(4)$ of this section, or

(iv) The preservation of a historically important land area or a certified historic structure, within the meaning of paragraph $(d)(5)$ of this section.

(2) Recreation or education -- (i) In general. The donation of a qualified real property interest to preserve land areas for the outdoor recreation of the general public or for the education of the general public will meet the conservation purposes test of this section. Thus, conservation purposes would include, for example, the preservation of a water area for the use of the public for boating or fishing, or a nature or hiking trail for the use of the public. 
(ii) Access. The preservation of land areas for recreation or education will not meet the test of this section unless the recreation or education is for the substantial and regular use of the general public.

(3) Protection of environmental system -- (i) In general. The donation of a qualified real property interest to protect a significant relatively natural habitat in which a fish, wildlife, or plant community, or similar ecosystem normally lives will meet the conservation purposes test of this section. The fact that the habitat or environment has been altered to some extent by human activity will not result in a deduction being denied under this section if the fish, wildlife, or plants continue to exist there in a relatively natural state. For example, the preservation of a lake formed by a man-made dam or a salt pond formed by a man-made dike would meet the conservation purposes test if the lake or pond were a nature feeding area for a wildlife community that included rare, endangered, or threatened native species.

(ii) Significant habitat or ecosystem. Significant habitats and ecosystems include, but are not limited to, habitats for rare, endangered, or threatened species of animal, fish, or plants; natural areas that represent high quality examples of a terrestrial community or aquatic community, such as islands that are undeveloped or not intensely developed where the coastal ecosystem is relatively intact; and natural areas which are included in, or which contribute to, the ecological viability of a local, state, or national park, nature preserve, wildlife refuge, wilderness area, or other similar conservation area.

(iii) Access. Limitations on public access to property that is the subject of a donation under this paragraph (d)(3) shall not render the donation nondeductible. For example, a restriction on all public access to the habitat of a threatened native animal species protected by a donation under this paragraph (d)(3) would not cause the donation to be nondeductible.

(4) Preservation of open space -- (i) In general. The donation of a qualified real property interest to preserve open space (including farmland and forest land) will meet the conservation purposes test of this section if such preservation is --

(A) Pursuant to a clearly delineated Federal, state, or local governmental conservation policy and will yield a significant public benefit, or

(B) For the scenic enjoyment of the general public and will yield a significant public benefit.

An open space easement donated on or after December 18, 1980, must meet the requirements of section $170(\mathrm{~h})$ in order to be deductible.

(ii) Scenic enjoyment -- (A) Factors. A contribution made for the preservation of open space may be for the scenic enjoyment of the general public. Preservation of land may be for the scenic enjoyment of the general public if development of the property would impair the scenic character of the local rural or urban landscape or would interfere with a scenic panorama that can be enjoyed from a park, nature preserve, road, waterbody, trail, or historic structure or land area, and such area or transportation way is open to, or utilized by, the public. "Scenic enjoyment" will be evaluated by considering all pertinent facts and circumstances germane to the contribution. Regional variations in topography, geology, biology, and cultural and economic conditions require flexibility in the application of this test, but do not lessen the burden on the taxpayer to 
demonstrate the scenic characteristics of a donation under this paragraph. The application of a particular objective factor to help define a view as "scenic" in one setting may in fact be entirely inappropriate in another setting. Among the factors to be considered are:

(1) The compatibility of the land use with other land in the vicinity;

(2) The degree of contrast and variety provided by the visual scene;

(3) The openness of the land (which would be a more significant factor in an urban or densely populated setting or in a heavily wooded area);

(4) Relief from urban closeness;

(5) The harmonious variety of shapes and textures;

(6) The degree to which the land use maintains the scale and character of the urban landscape to preserve open space, visual enjoyment, and sunlight for the surrounding area;

(7) The consistency of the proposed scenic view with a methodical state scenic identification program, such as a state landscape inventory; and

(8) The consistency of the proposed scenic view with a regional or local landscape inventory made pursuant to a sufficiently rigorous review process, especially if the donation is endorsed by an appropriate state or local governmental agency.

(B) Access. To satisfy the requirement of scenic enjoyment by the general public, visual (rather than physical) access to or across the property by the general public is sufficient. Under the terms of an open space easement on scenic property, the entire property need not be visible to the public for a donation to qualify under this section, although the public benefit from the donation may be insufficient to qualify for a deduction if only a small portion of the property is visible to the public.

(iii) Governmental conservation policy -- (A) In general. The requirement that the preservation of open space be pursuant to a clearly delineated Federal, state, or local governmental policy is intended to protect the types of property identified by representatives of the general public as worthy of preservation or conservation. A general declaration of conservation goals by a single official or legislative body is not sufficient. However, a governmental conservation policy need not be a certification program that identifies particular lots or small parcels of individually owned property. This requirement will be met by donations that further a specific, identified conservation project, such as the preservation of land within a state or local landmark district that is locally recognized as being significant to that district; the preservation of a wild or scenic river, the preservation of farmland pursuant to a state program for flood prevention and control; or the protection of the scenic, ecological, or historic character of land that is contiguous to, or an integral part of, the surroundings of existing recreation or conservation sites. For example, the donation of a perpetual conservation restriction to a qualified organization pursuant to a formal resolution or certification by a local governmental agency established under state law specifically identifying the subject property as worthy of protection for conservation purposes will meet the requirement of this paragraph. A program need not be funded to satisfy this requirement, but the program must involve a significant commitment by the government with respect to the 
conservation project. For example, a governmental program according preferential tax assessment or preferential zoning for certain property deemed worthy of protection for conservation purposes would constitute a significant commitment by the government.

(B) Effect of acceptance by governmental agency. Acceptance of an easement by an agency of the Federal Government or by an agency of a state or local government (or by a commission, authority, or similar body duly constituted by the state or local government and acting on behalf of the state or local government) tends to establish the requisite clearly delineated governmental policy, although such acceptance, without more, is not sufficient. The more rigorous the review process by the governmental agency, the more the acceptance of the easement tends to establish the requisite clearly delineated governmental policy. For example, in a state where the legislature has established an Environmental Trust to accept gifts to the state which meet certain conservation purposes and to submit the gifts to a review that requires the approval of the state's highest officials, acceptance of a gift by the Trust tends to establish the requisite clearly delineated governmental policy. However, if the Trust merely accepts such gifts without a review process, the requisite clearly delineated governmental policy is not established.

(C) Access. A limitation on public access to property subject to a donation under this paragraph (d)(4)(iii) shall not render the deduction nondeductible unless the conservation purpose of the donation would be undermined or frustrated without public access. For example, a donation pursuant to a governmental policy to protect the scenic character of land near a river requires visual access to the same extent as would a donation under paragraph (d)(4)(ii) of this section.

(iv) Significant public benefit -- (A) Factors. All contributions made for the preservation of open space must yield a significant public benefit. Public benefit will be evaluated by considering all pertinent facts and circumstances germane to the contribution. Factors germane to the evaluation of public benefit from one contribution may be irrelevant in determining public benefit from another contribution. No single factor will necessarily be determinative. Among the factors to be considered are:

(1) The uniqueness of the property to the area;

(2) The intensity of land development in the vicinity of the property (both existing development and foreseeable trends of development);

(3) The consistency of the proposed open space use with public programs (whether Federal, state or local) for conservation in the region, including programs for outdoor recreation, irrigation or water supply protection, water quality maintenance or enhancement, flood prevention and control, erosion control, shoreline protection, and protection of land areas included in, or related to, a government approved master plan or land management area;

(4) The consistency of the proposed open space use with existing private conservation programs in the area, as evidenced by other land, protected by easement or fee ownership by organizations referred to in $\S 1.170 \mathrm{~A}-14(\mathrm{c})(1)$, in close proximity to the property;

(5) The likelihood that development of the property would lead to or contribute to degradation of the scenic, natural, or historic character of the area; 
(6) The opportunity for the general public to use the property or to appreciate its scenic values;

(7) The importance of the property in preserving a local or regional landscape or resource that attracts tourism or commerce to the area;

(8) The likelihood that the donee will acquire equally desirable and valuable substitute property or property rights;

(9) The cost to the donee of enforcing the terms of the conservation restriction;

(10) The population density in the area of the property; and

(11) The consistency of the proposed open space use with a legislatively mandated program identifying particular parcels of land for future protection.

(B) Illustrations. The preservation of an ordinary tract of land would not in and of itself yield a significant public benefit, but the preservation of ordinary land areas in conjunction with other factors that demonstrate significant public benefit or the preservation of a unique land area for public employment would yield a significant public benefit. For example, the preservation of a vacant downtown lot would not by itself yield a significant public benefit, but the preservation of the downtown lot as a public garden would, absent countervailing factors, yield a significant public benefit. The following are other examples of contributions which would, absent countervailing factors, yield a significant public benefit: The preservation of farmland pursuant to a state program for flood prevention and control; the preservation of a unique natural land formation for the enjoyment of the general public; the preservation of woodland along a public highway pursuant to a government program to preserve the appearance of the area so as to maintain the scenic view from the highway; and the preservation of a stretch of undeveloped property located between a public highway and the ocean in order to maintain the scenic ocean view from the highway.

(v) Limitation. A deduction will not be allowed for the preservation of open space under section 170(h)(4)(A)(iii), if the terms of the easement permit a degree of intrusion or future development that would interfere with the essential scenic quality of the land or with the governmental conservation policy that is being furthered by the donation. See $\S 1.170 \mathrm{~A}-14(\mathrm{e})(2)$ for rules relating to inconsistent use.

(vi) Relationship of requirements -- (A) Clearly delineated governmental policy and significant public benefit. Although the requirements of "clearly delineated governmental policy" and "significant public benefit" must be met independently, for purposes of this section the two requirements may also be related. The more specific the governmental policy with respect to the particular site to be protected, the more likely the governmental decision, by itself, will tend to establish the significant public benefit associated with the donation. For example, while a statute in State X permitting preferential assessment for farmland is, by definition, governmental policy, it is distinguishable from a state statute, accompanied by appropriations, naming the $X$ River as a valuable resource and articulating the legislative policy that the $X$ River and the relatively natural quality of its surrounding be protected. On these facts, an open space easement on farmland in State $X$ would have to demonstrate additional factors to establish "significant public benefit." The specificity of the legislative mandate to protect the X River, however, would by itself tend to 
establish the significant public benefit associated with an open space easement on land fronting the $\mathrm{X}$ River.

(B) Scenic enjoyment and significant public benefit. With respect to the relationship between the requirements of "scenic enjoyment" and "significant public benefit," since the degrees of scenic enjoyment offered by a variety of open space easements are subjective and not as easily delineated as are increasingly specific levels of governmental policy, the significant public benefit of preserving a scenic view must be independently established in all cases.

(C) Donations may satisfy more than one test. In some cases, open space easements may be both for scenic enjoyment and pursuant to a clearly delineated governmental policy. For example, the preservation of a particular scenic view identified as part of a scenic landscape inventory by a rigorous governmental review process will meet the tests of both paragraphs $(d)(4)(i)(A)$ and (d)(4)(i)(B) of this section.

(5) Historic preservation -- (i) In general. The donation of a qualified real property interest to preserve an historically important land area or a certified historic structure will meet the conservation purposes test of this section. When restrictions to preserve a building or land area within a registered historic district permit future development on the site, a deduction will be allowed under this section only if the terms of the restrictions require that such development conform with appropriate local, state, or Federal standards for construction or rehabilitation within the district. See also, $\S 1.170 \mathrm{~A}-14(\mathrm{~h})(3)(\mathrm{ii})$.

(ii) Historically important land area. The term historically important land area includes:

(A) An independently significant land area including any related historic resources (for example, an archaeological site or a Civil War battlefield with related monuments, bridges, cannons, or houses) that meets the National Register Criteria for Evaluation in 36 CFR 60.4 (Pub. L. 89-665, 80 Stat. 915);

(B) Any land area within a registered historic district including any buildings on the land area that can reasonably be considered as contributing to the significance of the district; and

(C) Any land area (including related historic resources) adjacent to a property listed individually in the National Register of Historic Places (but not within a registered historic district) in a case where the physical or environmental features of the land area contribute to the historic or cultural integrity of the property.

(iii) Certified historic structure. The term certified historic structure, for purposes of this section, means any building, structure or land area which is --

(A) Listed in the National Register, or

(B) Located in a registered historic district (as defined in section 48(g)(3)(B)) and is certified by the Secretary of the Interior (pursuant to 36 CFR 67.4) to the Secretary of the Treasury as being of historic significance to the district.

A structure for purposes of this section means any structure, whether or not it is depreciable. Accordingly easements on private residences may qualify under this section. In addition, a structure would be considered to be a certified historic structure if it were certified either at the 
time the transfer was made or at the due date (including extensions) for filing the donor's return for the taxable year in which the contribution was made.

(iv) Access. (A) In order for a conservation contribution described in section $170(\mathrm{~h})(4)(\mathrm{A})(\mathrm{iv})$ and this paragraph $(\mathrm{d})(5)$ to be deductible, some visual public access to the donated property is required. In the case of an historically important land area, the entire property need not be visible to the public for a donation to qualify under this section. However, the public benefit from the donation may be insufficient to qualify for a deduction if only a small portion of the property is so visible. Where the historic land area or certified historic structure which is the subject of the donation is not visible from a public way (e.g., the structure is hidden from view by a wall or shrubbery, the structure is too far from the public way, or interior characteristics and features of the structure are the subject of the easement), the terms of the easement must be such that the general public is given the opportunity on a regular basis to view the characteristics and features of the property which are preserved by the easement to the extent consistent with the nature and condition of the property.

(B) Factors to be considered in determining the type and amount of public access required under paragraph (d)(5)(iv)(A) of this section include the historical significance of the donated property, the nature of the features that are the subject of the easement, the remoteness or accessibility of the site of the donated property, the possibility of physical hazards to the public visiting the property (for example, an unoccupied structure in a dilapidated condition), the extent to which public access would be an unreasonable intrusion on any privacy interests of individuals living on the property, the degree to which public access would impair the preservation interests which are the subject of the donation, and the availability of opportunities for the public to view the property by means other than visits to the site.

(C) The amount of access afforded the public by the donation of an easement shall be determined with reference to the amount of access permitted by the terms of the easement which are established by the donor, rather than the amount of access actually provided by the donee organization. However, if the donor is aware of any facts indicating that the amount of access that the donee organization will provide is significantly less than the amount of access permitted under the terms of the easement, then the amount of access afforded the public shall be determined with reference to this lesser amount.

(v) Examples. The provisions of paragraph (d)(5)(iv) of this section may be illustrated by the following examples:

Example 1. A and his family live in a house in a certified historic district in the State of X. The entire house, including its interior, has architectural features representing classic Victorian period architecture. A donates an exterior and interior easement on the property to a qualified organization but continues to live in the house with his family. A's house is surrounded by a high stone wall which obscures the public's view of it from the street. Pursuant to the terms of the easement, the house may be opened to the public from 10:00 a.m. to 4:00 p.m. on one Sunday in May and one Sunday in November each year for house and garden tours. These tours are to be under the supervision of the donee and open to members of the general public upon payment of a small fee. In addition, under the terms of the easement, the donee organization is given the right 
to photograph the interior and exterior of the house and distribute such photographs to magazines, newsletters, or other publicly available publications. The terms of the easement also permit persons affiliated with educational organizations, professional architectural associations, and historical societies to make an appointment through the donee organization to study the property. The donor is not aware of any facts indicating that the public access to be provided by the donee organization will be significantly less than that permitted by the terms of the easement. The 2 opportunities for public visits per year, when combined with the ability of the general public to view the architectural characteristics and features that are the subject of the easement through photographs, the opportunity for scholarly study of the property, and the fact that the house is used as an occupied residence, will enable the donation to satisfy the requirement of public access.

Example 2. B owns an unoccupied farmhouse built in the 1840's and located on a property that is adjacent to a Civil War battlefield. During the Civil War the farmhouse was used as quarters for Union troops. The battlefield is visited year round by the general public. The condition of the farmhouse is such that the safety of visitors will not be jeopardized and opening it to the public will not result in significant deterioration. The farmhouse is not visible from the battlefield or any public way. It is accessible only by way of a private road owned by B. B donates a conservation easement on the farmhouse to a qualified organization. The terms of the easement provide that the donee organization may open the property (via B's road) to the general public on four weekends each year from 8:30 a.m. to 4:00 p.m. The donation does not meet the public access requirement because the farmhouse is safe, unoccupied, and easily accessible to the general public who have come to the site to visit Civil War historic land areas (and related resources), but will only be open to the public on four weekends each year. However, the donation would meet the public access requirement if the terms of the easement permitted the donee organization to open the property to the public every other weekend during the year and the donor is not aware of any facts indicating that the donee organization will provide significantly less access than that permitted.

(e) Exclusively for conservation purposes -- (1) In general. To meet the requirements of this section, a donation must be exclusively for conservation purposes. See paragraphs (c)(1) and (g)(1) through (g)(6)(ii) of this section. A deduction will not be denied under this section when incidental benefit inures to the donor merely as a result of conservation restrictions limiting the uses to which the donor's property may be put.

(2) Inconsistent use. Except as provided in paragraph (e)(4) of this section, a deduction will not be allowed if the contribution would accomplish one of the enumerated conservation purposes but would permit destruction of other significant conservation interests. For example, the preservation of farmland pursuant to a State program for flood prevention and control would not qualify under paragraph $(\mathrm{d})(4)$ of this section if under the terms of the contribution a significant naturally occurring ecosystem could be injured or destroyed by the use of pesticides in the operation of the farm. However, this requirement is not intended to prohibit uses of the property, such as selective timber harvesting or selective farming if, under the circumstances, those uses do not impair significant conservation interests. 
(3) Inconsistent use permitted. A use that is destructive of conservation interests will be permitted only if such use is necessary for the protection of the conservation interests that are the subject of the contribution. For example, a deduction for the donation of an easement to preserve an archaeological site that is listed on the National Register of Historic Places will not be disallowed if site excavation consistent with sound archaeological practices may impair a scenic view of which the land is a part. A donor may continue a pre-existing use of the property that does not conflict with the conservation purposes of the gift.

(f) Examples. The provisions of this section relating to conservation purposes may be illustrated by the following examples.

Example 1. State $\mathrm{S}$ contains many large tract forests that are desirable recreation and scenic areas for the general public. The forests' scenic values attract millions of people to the State. However, due to the increasing intensity of land development in State $S$, the continued existence of forestland parcels greater than 45 acres is threatened. J grants a perpetual easement on a 100acre parcel of forestland that is part of one of the State's scenic areas to a qualifying organization. The easement imposes restrictions on the use of the parcel for the purpose of maintaining its scenic values. The restrictions include a requirement that the parcel be maintained forever as open space devoted exclusively to conservation purposes and wildlife protection, and that there be no commercial, industrial, residential, or other development use of such parcel. The law of State $S$ recognizes a limited public right to enter private land, particularly for recreational pursuits, unless such land is posted or the landowner objects. The easement specifically restricts the landowner from posting the parcel, or from objecting, thereby maintaining public access to the parcel according to the custom of the State. J's parcel provides the opportunity for the public to enjoy the use of the property and appreciate its scenic values. Accordingly, J's donation qualifies for a deduction under this section.

Example 2. A qualified conservation organization owns Greenacre in fee as a nature preserve. Greenacre contains a high quality example of a tall grass prairie ecosystem. Farmacre, an operating farm, adjoins Greenacre and is a compatible buffer to the nature preserve. Conversion of Farmacre to a more intense use, such as a housing development, would adversely affect the continued use of Greenacre as a nature preserve because of human traffic generated by the development. The owner of Farmacre donates an easement preventing any future development on Farmacre to the qualified conservation organization for conservation purposes. Normal agricultural uses will be allowed on Farmacre. Accordingly, the donation qualifies for a deduction under this section.

Example 3. H owns Greenacre, a 900-acre parcel of woodland, rolling pasture, and orchards on the crest of a mountain. All of Greenacre is clearly visible from a nearby national park. Because of the strict enforcement of an applicable zoning plan, the highest and best use of Greenacre is as a subdivision of 40 -acre tracts. $\mathrm{H}$ wishes to donate a scenic easement on Greenacre to a qualifying conservation organization, but $\mathrm{H}$ would like to reserve the right to subdivide Greenacre into 90acre parcels with no more than one single-family home allowable on each parcel. Random building on the property, even as little as one home for each 90 acres, would destroy the scenic character of the view. Accordingly, no deduction would be allowable under this section. 
Example 4. Assume the same facts as in example (3), except that not all of Greenacre is visible from the park and the deed of easement allows for limited cluster development of no more than five nine-acre clusters (with four houses on each cluster) located in areas generally not visible from the national park and subject to site and building plan approval by the donee organization in order to preserve the scenic view from the park. The donor and the donee have already identified sites where limited cluster development would not be visible from the park or would not impair the view. Owners of homes in the clusters will not have any rights with respect to the surrounding Greenacre property that are not also available to the general public. Accordingly, the donation qualifies for a deduction under this section.

Example 5. In order to protect State S's declining open space that is suited for agricultural use from increasing development pressure that has led to a marked decline in such open space, the Legislature of State S passed a statute authorizing the purchase of "agricultural land development rights" on open acreage. Agricultural land development rights allow the State to place agricultural preservation restrictions on land designated as worthy of protection in order to preserve open space and farm resources. Agricultural preservation restrictions prohibit or limit construction or placement of buildings except those used for agricultural purposes or dwellings used for family living by the farmer and his family and employees; removal of mineral substances in any manner that adversely affects the land's agricultural potential; or other uses detrimental to retention of the land for agricultural use. Money has been appropriated for this program and some landowners have in fact sold their "agricultural land development rights" to State S. K owns and operates a small dairy farm in State $\mathrm{S}$ located in an area designated by the Legislature as worthy of protection. $\mathrm{K}$ desires to preserve his farm for agricultural purposes in perpetuity. Rather than selling the development rights to State $\mathrm{S}, \mathrm{K}$ grants to a qualified organization an agricultural preservation restriction on his property in the form of a conservation easement. $K$ reserves to himself, his heirs and assigns the right to manage the farm consistent with sound agricultural and management practices. The preservation of $\mathrm{K}$ 's land is pursuant to a clearly delineated governmental policy of preserving open space available for agricultural use, and will yield a significant public benefit by preserving open space against increasing development pressures.

(g) Enforceable in perpetuity -- (1) In general. In the case of any donation under this section, any interest in the property retained by the donor (and the donor's successors in interest) must be subject to legally enforceable restrictions (for example, by recordation in the land records of the jurisdiction in which the property is located) that will prevent uses of the retained interest inconsistent with the conservation purposes of the donation. In the case of a contribution of a remainder interest, the contribution will not qualify if the tenants, whether they are tenants for life or a term of years, can use the property in a manner that diminishes the conservation values which are intended to be protected by the contribution.

(2) Protection of a conservation purpose in case of donation of property subject to a mortgage. In the case of conservation contributions made after February 13, 1986, no deduction will be permitted under this section for an interest in property which is subject to a mortgage unless the mortgagee subordinates its rights in the property to the right of the qualified organization to enforce the conservation purposes of the gift in perpetuity. For conservation contributions made prior to February 14, 1986, the requirement of section $170(h)(5)(A)$ is satisfied 
in the case of mortgaged property (with respect to which the mortgagee has not subordinated its rights) only if the donor can demonstrate that the conservation purpose is protected in perpetuity without subordination of the mortgagee's rights.

(3) Remote future event. A deduction shall not be disallowed under section 170(f)(3)(B)(iii) and this section merely because the interest which passes to, or is vested in, the donee organization may be defeated by the performance of some act or the happening of some event, if on the date of the gift it appears that the possibility that such act or event will occur is so remote as to be negligible. See paragraph (e) of $\S 1.170 \mathrm{~A}-1$. For example, a state's statutory requirement that use restrictions must be rerecorded every 30 years to remain enforceable shall not, by itself, render an easement nonperpetual.

(4) Retention of qualified mineral interest -- (i) In general. Except as otherwise provided in paragraph (g)(4)(ii) of this section, the requirements of this section are not met and no deduction shall be allowed in the case of a contribution of any interest when there is a retention by any person of a qualified mineral interest (as defined in paragraph (b)(1)(i) of this section) if at any time there may be extractions or removal of minerals by any surface mining method. Moreover, in the case of a qualified mineral interest gift, the requirement that the conservation purposes be protected in perpetuity is not satisfied if any method of mining that is inconsistent with the particular conservation purposes of a contribution is permitted at any time. See also $\S 1.170 \mathrm{~A}-$ 14(e)(2). However, a deduction under this section will not be denied in the case of certain methods of mining that may have limited, localized impact on the real property but that are not irremediably destructive of significant conservation interests. For example, a deduction will not be denied in a case where production facilities are concealed or compatible with existing topography and landscape and when surface alteration is to be restored to its original state.

(ii) Exception for qualified conservation contributions after July 1984. (A) A contribution made after July 18, 1984, of a qualified real property interest described in section 170(h)(2)(A) shall not be disqualified under the first sentence of paragraph $(\mathrm{g})(4)(\mathrm{i})$ of this section if the following requirements are satisfied.

(1) The ownership of the surface estate and mineral interest were separated before June 13, 1976 , and remain so separated up to and including the time of the contribution.

(2) The present owner of the mineral interest is not a person whose relationship to the owner of the surface estate is described at the time of the contribution in section $267(b)$ or section 707(b), and

(3) The probability of extraction or removal of minerals by any surface mining method is so remote as to be negligible.

Whether the probability of extraction or removal of minerals by surface mining is so remote as to be negligible is a question of fact and is to be made on a case by case basis. Relevant factors to be considered in determining if the probability of extraction or removal of minerals by surface mining is so remote as to be negligible include: Geological, geophysical or economic data showing the absence of mineral reserves on the property, or the lack of commercial feasibility at the time of the contribution of surface mining the mineral interest. 
(B) If the ownership of the surface estate and mineral interest first became separated after June 12, 1976, no deduction is permitted for a contribution under this section unless surface mining on the property is completely prohibited.

(iii) Examples. The provisions of paragraph (g)(4)(i) and (ii) of this section may be illustrated by the following examples:

Example 1. K owns 5,000 acres of bottomland hardwood property along a major watershed system in the southern part of the United States. Agencies within the Department of the Interior have determined that southern bottomland hardwoods are a rapidly diminishing resource and a critical ecosystem in the south because of the intense pressure to cut the trees and convert the land to agricultural use. These agencies have further determined (and have indicated in correspondence with $\mathrm{K}$ ) that bottomland hardwoods provide a superb habitat for numerous species and play an important role in controlling floods and purifying rivers. $\mathrm{K}$ donates to a qualified organization his entire interest in this property other than his interest in the gas and oil deposits that have been identified under K's property. K covenants and can ensure that, although drilling for gas and oil on the property may have some temporary localized impact on the real property, the drilling will not interfere with the overall conservation purpose of the gift, which is to protect the unique bottomland hardwood ecosystem. Accordingly, the donation qualifies for a deduction under this section.

Example 2. Assume the same facts as in example (1), except that in $1979, \mathrm{~K}$ sells the mineral interest to A, an unrelated person, in an arm's-length transaction, subject to a recorded prohibition on the removal of any minerals by any surface mining method and a recorded prohibition against any mining technique that will harm the bottomland hardwood ecosystem. After the sale to $\mathrm{A}, \mathrm{K}$ donates a qualified real property interest to a qualified organization to protect the bottomland hardwood ecosystem. Since at the time of the transfer, surface mining and any mining technique that will harm the bottomland hardwood ecosystem are completely prohibited, the donation qualifies for a deduction under this section.

(5) Protection of conservation purpose where taxpayer reserves certain rights. (i) Documentation. In the case of a donation made after February 13, 1986, of any qualified real property interest when the donor reserves rights the exercise of which may impair the conservation interests associated with the property, for a deduction to be allowable under this section the donor must make available to the donee, prior to the time the donation is made, documentation sufficient to establish the condition of the property at the time of the gift. Such documentation is designed to protect the conservation interests associated with the property, which although protected in perpetuity by the easement, could be adversely affected by the exercise of the reserved rights. Such documentation may include:

(A) The appropriate survey maps from the United States Geological Survey, showing the property line and other contiguous or nearby protected areas;

(B) A map of the area drawn to scale showing all existing man-made improvements or incursions (such as roads, buildings, fences, or gravel pits), vegetation and identification of flora and fauna (including, for example, rare species locations, animal breeding and roosting areas, and 
migration routes), land use history (including present uses and recent past disturbances), and distinct natural features (such as large trees and aquatic areas);

(C) An aerial photograph of the property at an appropriate scale taken as close as possible to the date the donation is made; and

(D) On-site photographs taken at appropriate locations on the property. If the terms of the donation contain restrictions with regard to a particular natural resource to be protected, such as water quality or air quality, the condition of the resource at or near the time of the gift must be established. The documentation, including the maps and photographs, must be accompanied by a statement signed by the donor and a representative of the donee clearly referencing the documentation and in substance saying "This natural resources inventory is an accurate representation of [the protected property] at the time of the transfer.".

(ii) Donee's right to inspection and legal remedies. In the case of any donation referred to in paragraph $(\mathrm{g})(5)(\mathrm{i})$ of this section, the donor must agree to notify the donee, in writing, before exercising any reserved right, e.g. the right to extract certain minerals which may have an adverse impact on the conservation interests associated with the qualified real property interest. The terms of the donation must provide a right of the donee to enter the property at reasonable times for the purpose of inspecting the property to determine if there is compliance with the terms of the donation. Additionally, the terms of the donation must provide a right of the donee to enforce the conservation restrictions by appropriate legal proceedings, including but not limited to, the right to require the restoration of the property to its condition at the time of the donation.

(6) Extinguishment. (i) In general. If a subsequent unexpected change in the conditions surrounding the property that is the subject of a donation under this paragraph can make impossible or impractical the continued use of the property for conservation purposes, the conservation purpose can nonetheless be treated as protected in perpetuity if the restrictions are extinguished by judicial proceeding and all of the donee's proceeds (determined under paragraph (g)(6)(ii) of this section) from a subsequent sale or exchange of the property are used by the donee organization in a manner consistent with the conservation purposes of the original contribution.

(ii) Proceeds. In case of a donation made after February 13, 1986, for a deduction to be allowed under this section, at the time of the gift the donor must agree that the donation of the perpetual conservation restriction gives rise to a property right, immediately vested in the donee organization, with a fair market value that is at least equal to the proportionate value that the perpetual conservation restriction at the time of the gift, bears to the value of the property as a whole at that time. See $\S 1.170 \mathrm{~A}-14(\mathrm{~h})(3)(\mathrm{iii})$ relating to the allocation of basis. For purposes of this paragraph $(g)(6)(i i)$, that proportionate value of the donee's property rights shall remain constant. Accordingly, when a change in conditions give rise to the extinguishment of a perpetual conservation restriction under paragraph $(\mathrm{g})(6)(\mathrm{i})$ of this section, the donee organization, on a subsequent sale, exchange, or involuntary conversion of the subject property, must be entitled to a portion of the proceeds at least equal to that proportionate value of the perpetual conservation restriction, unless state law provides that the donor is entitled to the full proceeds from the conversion without regard to the terms of the prior perpetual conservation restriction. 
(h) Valuation -- (1) Entire interest of donor other than qualified mineral interest. The value of the contribution under section 170 in the case of a contribution of a taxpayer's entire interest in property other than a qualified mineral interest is the fair market value of the surface rights in the property contributed. The value of the contribution shall be computed without regard to the mineral rights. See paragraph (h)(4), example (1), of this section.

(2) Remainder interest in real property. In the case of a contribution of any remainder interest in real property, section $170(f)(4)$ provides that in determining the value of such interest for purposes of section 170, depreciation and depletion of such property shall be taken into account. See $\S$ 1.170A-12. In the case of the contribution of a remainder interest for conservation purposes, the current fair market value of the property (against which the limitations of $\S 1.170 \mathrm{~A}$ 12 are applied) must take into account any pre-existing or contemporaneously recorded rights limiting, for conservation purposes, the use to which the subject property may be put.

(3) Perpetual conservation restriction -- (i) In general. The value of the contribution under section 170 in the case of a charitable contribution of a perpetual conservation restriction is the fair market value of the perpetual conservation restriction at the time of the contribution. See $\S$ $1.170 \mathrm{~A}-7$ (c). If there is a substantial record of sales of easements comparable to the donated easement (such as purchases pursuant to a governmental program), the fair market value of the donated easement is based on the sales prices of such comparable easements. If no substantial record of market-place sales is available to use as a meaningful or valid comparison, as a general rule (but not necessarily in all cases) the fair market value of a perpetual conservation restriction is equal to the difference between the fair market value of the property it encumbers before the granting of the restriction and the fair market value of the encumbered property after the granting of the restriction. The amount of the deduction in the case of a charitable contribution of a perpetual conservation restriction covering a portion of the contiguous property owned by a donor and the donor's family (as defined in section 267(c)(4)) is the difference between the fair market value of the entire contiguous parcel of property before and after the granting of the restriction. If the granting of a perpetual conservation restriction after January 14, 1986, has the effect of increasing the value of any other property owned by the donor or a related person, the amount of the deduction for the conservation contribution shall be reduced by the amount of the increase in the value of the other property, whether or not such property is contiguous. If, as a result of the donation of a perpetual conservation restriction, the donor or a related person receives, or can reasonably expect to receive, financial or economic benefits that are greater than those that will inure to the general public from the transfer, no deduction is allowable under this section. However, if the donor or a related person receives, or can reasonably expect to receive, a financial or economic benefit that is substantial, but it is clearly shown that the benefit is less than the amount of the transfer, then a deduction under this section is allowable for the excess of the amount transferred over the amount of the financial or economic benefit received or reasonably expected to be received by the donor or the related person. For purposes of this paragraph (h)(3)((i), related person shall have the same meaning as in either section 267(b) or section 707(b). (See example (10) of paragraph (h)(4) of this section.)

(ii) Fair market value of property before and after restriction. If before and after valuation is used, the fair market value of the property before contribution of the conservation restriction 
must take into account not only the current use of the property but also an objective assessment of how immediate or remote the likelihood is that the property, absent the restriction, would in fact be developed, as well as any effect from zoning, conservation, or historic preservation laws that already restrict the property's potential highest and best use. Further, there may be instances where the grant of a conservation restriction may have no material effect on the value of the property or may in fact serve to enhance, rather than reduce, the value of property. In such instances no deduction would be allowable. In the case of a conservation restriction that allows for any development, however limited, on the property to be protected, the fair market value of the property after contribution of the restriction must take into account the effect of the development. In the case of a conservation easement such as an easement on a certified historic structure, the fair market value of the property after contribution of the restriction must take into account the amount of access permitted by the terms of the easement. Additionally, if before and after valuation is used, an appraisal of the property after contribution of the restriction must take into account the effect of restrictions that will result in a reduction of the potential fair market value represented by highest and best use but will, nevertheless, permit uses of the property that will increase its fair market value above that represented by the property's current use. The value of a perpetual conservation restriction shall not be reduced by reason of the existence of restrictions on transfer designed solely to ensure that the conservation restriction will be dedicated to conservation purposes. See $\S 1.170 A-14$ (c)(3).

(iii) Allocation of basis. In the case of the donation of a qualified real property interest for conservation purposes, the basis of the property retained by the donor must be adjusted by the elimination of that part of the total basis of the property that is properly allocable to the qualified real property interest granted. The amount of the basis that is allocable to the qualified real property interest shall bear the same ratio to the total basis of the property as the fair market value of the qualified real property interest bears to the fair market value of the property before the granting of the qualified real property interest. When a taxpayer donates to a qualifying conservation organization an easement on a structure with respect to which deductions are taken for depreciation, the reduction required by this paragraph (h)(3)(ii) in the basis of the property retained by the taxpayer must be allocated between the structure and the underlying land.

(4) Examples. The provisions of this section may be illustrated by the following examples. In examples illustrating the value or deductibility of donations, the applicable restrictions and limitations of $\S 1.170 \mathrm{~A}-4$, with respect to reduction in amount of charitable contributions of certain appreciated property, and $\S 1.170 \mathrm{~A}-8$, with respect to limitations on charitable deductions by individuals. must also be taken into account.

Example 1. A owns Goldacre, a property adjacent to a state park. A wants to donate Goldacre to the state to be used as part of the park, but A wants to reserve a qualified mineral interest in the property, to exploit currently and to devise at death. The fair market value of the surface rights in Goldacre is $\$ 200,000$ and the fair market value of the mineral rights in $\$ 100.000$. In order to ensure that the quality of the park will not be degraded, restrictions must be imposed on the right to extract the minerals that reduce the fair market value of the mineral rights to $\$ 80,000$. Under this section, the value of the contribution is $\$ 200,000$ (the value of the surface rights). 
Example 2. In 1984 B, who is 62, donates a remainder interest in Greenacre to a qualifying organization for conservation purposes. Greenacre is a tract of 200 acres of undeveloped woodland that is valued at $\$ 200,000$ at its highest and best use. Under $\S 1.170 \mathrm{~A}-12(\mathrm{~b})$, the value of a remainder interest in real property following one life is determined under $\S 25.2512-5$ of this chapter (Gift Tax Regulations). (See $\S 25.2512-5 \mathrm{~A}$ of this chapter with respect to the valuation of annuities, interests for life or term of years, and remainder or reversionary interests transferred before May 1, 1999.) Accordingly, the value of the remainder interest, and thus the amount eligible for an income tax deduction under section $170(\mathrm{f})$, is $\$ 55,996$ (\$200,000 x .27998).

Example 3. Assume the same facts as in example (2), except that Greenacre is B's 200-acre estate with a home built during the colonial period. Some of the acreage around the home is cleared; the balance of Greenacre, except for access roads, is wooded and undeveloped. See section 170(f)(3)(B)(i). However, B would like Greenacre to be maintained in its current state after his death, so he donates a remainder interest in Greenacre to a qualifying organization for conservation purposes pursuant to section $170(f)(3)(B)(i i i)$ and $(h)(2)(B)$. At the time of the gift the land has a value of $\$ 200,000$ and the house has a value of $\$ 100,000$. The value of the remainder interest, and thus the amount eligible for an income tax deduction under section 170(f), is computed pursuant to $\S 1.170 A-12$. See $\S 1.170 A-12(b)(3)$.

Example 4. Assume the same facts as in example (2), except that at age 62 instead of donating a remainder interest B donates an easement in Greenacre to a qualifying organization for conservation purposes. The fair market value of Greenacre after the donation is reduced to $\$$ 110,000 . Accordingly, the value of the easement, and thus the amount eligible for a deduction under section $170(f)$, is $\$ 90,000$ (\$200,000 less $\$ 110,000)$.

Example 5. Assume the same facts as in example (4), and assume that three years later, at age 65, B decides to donate a remainder interest in Greenacre to a qualifying organization for conservation purposes. Increasing real estate values in the area have raised the fair market value of Greenacre (subject to the easement) to $\$ 130,000$. Accordingly, the value of the remainder interest, and thus the amount eligible for a deduction under section $170(f)$, is $\$ 41,639(\$ 130,000$ x.32030).

Example 6. Assume the same facts as in example (2), except that at the time of the donation of a remainder interest in Greenacre, B also donates an easement to a different qualifying organization for conservation purposes. Based on all the facts and circumstances, the value of the easement is determined to be $\$ 100,000$. Therefore, the value of the property after the easement is $\$ 100,000$ and the value of the remainder interest, and thus the amount eligible for deduction under section $170(\mathrm{f})$, is $\$ 27,998$ ( $\$ 100,000 \times$.27998).

Example 7. C owns Greenacre, a 200-acre estate containing a house built during the colonial period. At its highest and best use, for home development, the fair market value of Greenacre is $\$$ 300,000 . C donates an easement (to maintain the house and Green acre in their current state) to a qualifying organization for conservation purposes. The fair market value of Greenacre after the donation is reduced to $\$ 125,000$. Accordingly, the value of the easement and the amount eligible for a deduction under section $170(f)$ is $\$ 175.000$ ( $\$ 300,000$ less $\$ 125,000)$. 
Example 8. Assume the same facts as in example (7) and assume that three years later, C decides to donate a remainder interest in Greenacre to a qualifying organization for conservation purposes. Increasing real estate values in the area have raised the fair market value of Greenacre to $\$ 180.000$. Assume that because of the perpetual easement prohibiting any development of the land, the value of the house is $\$ 120,000$ and the value of the land is $\$ 60,000$. The value of the remainder interest, and thus the amount eligible for an income tax deduction under section 170(f), is computed pursuant to $\S 1.170 \mathrm{~A}-12$. See $\S 1.170 \mathrm{~A}-12(\mathrm{~b})(3)$.

Example 9. D owns property with a basis of $\$ 20,000$ and a fair market value of $\$ 80,000$. D donates to a qualifying organization an easement for conservation purposes that is determined under this section to have a fair market value of $\$ 60,000$. The amount of basis allocable to the easement is $\$ 15,000(\$ 60,000 / \$ 80,000=\$ 15,000 / \$ 20,000)$. Accordingly, the basis of the property is reduced to $\$ 5,000$ ( $\$ 20,000$ minus $\$ 15,000)$.

Example 10. E owns 10 one-acre lots that are currently woods and parkland. The fair market value of each of E's lots is $\$ 15,000$ and the basis of each lot is $\$ 3,000$. E grants to the county a perpetual easement for conservation purposes to use and maintain eight of the acres as a public park and to restrict any future development on those eight acres. As a result of the restrictions, the value of the eight acres is reduced to $\$ 1,000$ an acre. However, by perpetually restricting development on this portion of the land, $\mathrm{E}$ has ensured that the two remaining acres will always be bordered by parkland, thus increasing their fair market value to $\$ 22,500$ each. If the eight acres represented all of $E$ 's land, the fair market value of the easement would be $\$ 112,000$, an amount equal to the fair market value of the land before the granting of the easement $(8 \times \$ 15,000=\$$ $120,000)$ minus the fair market value of the encumbered land after the granting of the easement $(8 \times \$ 1,000=\$ 8,000)$. However, because the easement only covered a portion of the taxpayer's contiguous land, the amount of the deduction under section 170 is reduced to $\$ 97,000$ (\$150,000 - $\$ 53,000)$, that is, the difference between the fair market value of the entire tract of land before $(\$ 150,000)$ and after $((8 \times \$ 1,000)+(2 \times \$ 22,500))$ the granting of the easement.

Example 11. Assume the same facts as in example (10). Since the easement covers a portion of E's land, only the basis of that portion is adjusted. Therefore, the amount of basis allocable to the easement is $\$ 22,400((8 \times \$ 3,000) \times(\$ 112,000 / \$ 120,000))$. Accordingly, the basis of the eight acres encumbered by the easement is reduced to $\$ 1,600(\$ 24,000-\$ 22,400)$, or $\$ 200$ for each acre. The basis of the two remaining acres is not affected by the donation.

Example 12. $\mathrm{F}$ owns and uses as professional offices a two-story building that lies within a registered historic district. F's building is an outstanding example of period architecture with a fair market value of $\$ 125,000$. Restricted to its current use, which is the highest and best use of the property without making changes to the facade, the building and lot would have a fair market value of $\$ 100,000$, of which $\$ 80,000$ would be allocable to the building and $\$ 20,000$ would be allocable to the lot. F's basis in the property is $\$ 50,000$, of which $\$ 40,000$ is allocable to the building and $\$ 10,000$ is allocable to the lot. F's neighborhood is a mix of residential and commercial uses, and it is possible that $\mathrm{F}$ (or another owner) could enlarge the building for more extensive commercial use, which is its highest and best use. However, this would require changes to the facade. $\mathrm{F}$ would like to donate to a qualifying preservation organization an easement restricting any changes to the facade and promising to maintain the facade in perpetuity. The 
donation would qualify for a deduction under this section. The fair market value of the easement is $\$ 25,000$ (the fair market value of the property before the easement, $\$ 125,000$, minus the fair market value of the property after the easement, $\$ 100,000)$. Pursuant to $\S 1.170 \mathrm{~A}-14(\mathrm{~h})(3)(\mathrm{iii})$, the basis allocable to the easement is $\$ 10,000$ and the basis of the underlying property (building and lot) is reduced to $\$ 40,000$.

(i) Substantiation requirement. If a taxpayer makes a qualified conservation contribution and claims a deduction, the taxpayer must maintain written records of the fair market value of the underlying property before and after the donation and the conservation purpose furthered by the donation and such information shall be stated in the taxpayer's income tax return if required by the return or its instructions. See also $\S 1.170 \mathrm{~A}-13$ (c) (relating to substantiation requirements for deductions in excess of \$5,000 for charitable contributions made after 1984), and section 6659 (relating to additions to tax in the case of valuation overstatements).

(j) Effective date. Except as otherwise provided in $\S 1.170 \mathrm{~A}-14(\mathrm{~g})(4)(\mathrm{ii})$, this section applies only to contributions made on or after December 18, 1980. 


\section{$\underline{\text { Appendix C }}$}

\section{Table of \& 170(h) Deduction Cases}

\section{Table Structure}

The Table below lists the cases involving challenges to charitable income tax deductions claimed with respect to conservation easement donations. Given that $\S 170(\mathrm{~h})$ and the Treasury Regulations are effective only for transfers made on or after December 18, 1980, ${ }^{1}$ the cases are separated into two groups:

1. those involving donations made before the effective date of $\S 170(\mathrm{~h})$ (pre- $\S$ $170(\mathrm{~h})$ cases) and

2. those involving donations made on or after the effective date of $\S 170(\mathrm{~h})$ (post$\S 170(\mathrm{~h})$ cases).

Substantial changes were made to the deduction provision with the enactment of $\S 170(\mathrm{~h})$ in 1980. Accordingly, the law in effect on the date of the donation may be an important factor in analyzing the relevance of an older case to a current controversy. ${ }^{2}$

\section{Precedential Value of Tax Court Cases}

The Tax Court issues several different types of opinions, the precedential value of which differs.

1. Summary Opinions. Certain disputes (for example, disputes involving deficiencies of $\$ 50,000$ or less for each year at issue) qualify for simplified or "S case" procedures. The Tax Court generally issues Summary Opinions in these cases, and Summary Opinions cannot be relied on as precedent or appealed.

2. Regular Opinions and Memorandum Opinions. The Tax Court generally issues two types of opinions in cases that are not "S" cases.

a. Opinions, sometimes referred to as "Regular Opinions," (cited as “T.C.”) are generally issued in cases that the Tax Court believes involve sufficiently

\footnotetext{
${ }^{1}$ Pub. L. 96-541, 94 Stat. 3206, §6(d). Treas. Reg. § 1.170A-14(j). The mortgage subordination, division of proceeds, baseline documentation, and donee notification, access, and enforcement rights requirements apply only to donations made after February 13, 1986. See Treas. Reg. §§ 1.170A-14(g)(2), -14(g)(6)(ii), -14(g)(5)(i), -14(g)(5)(ii). The provision requiring a reduction in amount of the donor's deduction for any increase in the value of certain property owned by the donor or a related person as a result of the donation applies only to donations made after January 14, 1986. See id. $\S$ 1.170A-14(h)(3)(i).

${ }^{2}$ For example, cases involving interpretation of the deduction provision in effect before $\S 170(\mathrm{~h})$ was enacted should not be relied upon in interpreting new requirements added to the deduction provision in 1980 to curb abuses and ensure protection of the federal investment, such as $\S 170(\mathrm{~h})(5)(\mathrm{A})$ 's new "protected-in-perpetuity" requirement. On the other, hand, some of the general rules governing valuation discussed in the older cases are still relevant to current controversies.
} 
important legal issues or principles. Regular Opinions can be cited as legal authority and appealed, and the Tax Court treats them as binding precedent.

b. Memorandum Opinions (cited at "T.C. Memo.") are generally issued in cases that do not involve novel legal issues and, instead, address situations where the law is settled or factually driven. Memorandum Opinions can be cited as legal authority and appealed, but the Tax Court does not treat them as binding precedent.

The Chief Judge of the Tax Court decides whether an opinion will be issued as a Regular Opinion or a Memorandum Opinion.

3. Bench Opinions. A Tax Court judge is authorized to issue a Bench Opinion in an $\mathrm{S}$ case or a regular case when the judge is "satisfied as to the factual conclusions to be reached in the case and that the law to be applied thereto is clear." To issue a Bench Opinion, the judge orally states the findings of fact and the opinion in court during the trial session and a transcript reflecting the findings of fact and opinion is sent to the parties. Bench Opinions cannot be relied upon as precedent.

\section{Tax Court Opinions}

T.C. and T.C. Memo. Opinions starting 09/25/95 and Summary Opinions starting 01/01/01 are available at https://www.ustaxcourt.gov/UstcInOp/OpinionSearch.aspx. 


\begin{tabular}{|c|c|c|}
\hline Pre- $\$ 170(\mathrm{~h})$ Cases (In Order of Final Opinion Date) & $\underline{\text { Date of }}$ & $\underline{\text { Holder }}$ \\
\hline Thayer v. Comm'r, T.C. Memo. 1977-370 & 1969 & $\mathrm{VOF}^{3}$ \\
\hline Todd v. U.S., 617 F. Supp. 253 (W.D. Pa. 1985) & 1979 & $\mathrm{WPC}^{4}$ \\
\hline Hilborn v. Comm'r, 85 T.C. 677 (1985) & 1979 & $\mathrm{VCC}^{5}$ \\
\hline Stanley Works v. Comm'r, 87 T.C. 389 (1986) & 1977 & $\mathrm{HVA}^{6}$ \\
\hline $\begin{array}{l}\text { Akers v. Comm'r, } 799 \text { F.2d } 243 \text { (6th Cir. 1986), } \\
\text { aff'g T.C. Memo. 1984-490 }\end{array}$ & 1977 & $\mathrm{TCL}^{7}$ \\
\hline Symington v. Comm'r, 87 T.C. 892 (1986) & 1979 & VOF \\
\hline Stotler v. Comm'r, T.C. Memo. 1987-275 & 1979 & $\begin{array}{c}\text { Monterey } \\
\text { County, CA }\end{array}$ \\
\hline $\begin{array}{l}\text { Fannon v. Comm'r, } 842 \text { F.2d } 1290 \text { (4th Cir. 1988) (unpublished), } \\
\text { modifying T.C. Memo. 1986-572 }\end{array}$ & 1979 & VOF \\
\hline Fannon v. Comm'r, T.C. Memo. 1989-136 & 1978 & VOF \\
\hline Dennis v. U.S., 70 A.F.T.R. 2d 92-5946 (E.D. Va. 1992) & $\begin{array}{c}\text { Nov. } 8 \\
1980 \\
\end{array}$ & VOF \\
\hline $\begin{array}{l}\text { McLennan v. U.S., } 994 \text { F.2d } 839 \text { (Fed. Cir. 1993), } \\
\text { aff'g } 24 \text { Cl. Ct. } 102 \text { (1991) and } 23 \text { Cl. Ct. } 99 \text { (1991) }\end{array}$ & $\begin{array}{c}\text { Nov. 10, } \\
1980\end{array}$ & WPC \\
\hline \multicolumn{2}{|l|}{ 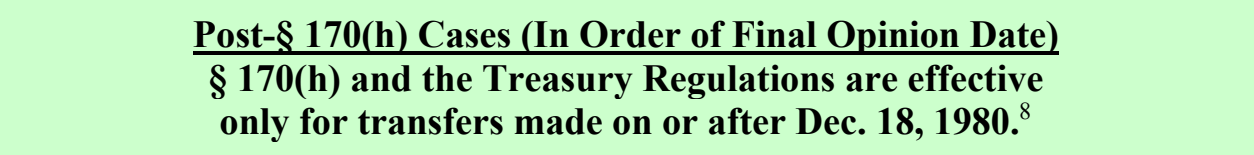 } & \\
\hline \multicolumn{3}{|l|}{1988 through 2000} \\
\hline Nicoladis v. Comm'r, T.C. Memo. 1988-163 & 1981 & $\mathrm{PANO}^{9}$ \\
\hline Losch v. Comm'r, T.C. Memo. 1988-230 & $\begin{array}{l}\text { Dec. 24, } \\
1980\end{array}$ & NTHP $^{10}$ \\
\hline Richmond v. U.S., 699 F. Supp. 578 (E.D. La. 1988) & $\begin{array}{l}\text { Dec. 29, } \\
1980\end{array}$ & $\mathrm{VCC}$ \\
\hline Higgins v. Comm'r, T.C. Memo. 1990-103 & 1981 & MET $^{11}$ \\
\hline Dorsey v. Comm'r, T.C. Memo. 1990-242 & 1981 & $\mathrm{HFC}^{12}$ \\
\hline $\begin{array}{l}\text { Griffin v. Comm'r, } 911 \text { F.2d } 1124 \text { (5th Cir. 1990), } \\
\text { aff'g T.C. Memo. 1989-130 }\end{array}$ & 1981 & HFC \\
\hline $\begin{array}{l}\text { Schapiro v. Comm'r, T.C. Memo. 1991-128; IRS AOD-1991-23 } \\
\text { (nonacquiesence) }\end{array}$ & $\begin{array}{l}1981 \\
1984\end{array}$ & MET \\
\hline Clemens v. Comm'r, T.C. Memo. 1992-436 & 1982 & VOLF $^{13}$ \\
\hline Schwab v. Comm'r, T.C. Memo. 1994-232 & 1983 & $\mathrm{AFT}^{14}$ \\
\hline \multicolumn{3}{|c|}{$\begin{array}{l}3 \text { Virginia Outdoors Foundation. } \\
{ }^{4} \text { Western Pennsylvania Conservancy. } \\
{ }^{5} \text { Vieux Carre Commission. } \\
{ }^{6} \text { Housatonic Valley Association. } \\
{ }^{7} \text { Tennessee Conservation League. } \\
{ }^{8} \text { See supra note } 1 \text { for exceptions to the effective date for some of the Treasury Regulation provisions. } \\
{ }^{9} \text { Preservation Alliance of New Orleans. } \\
10 \text { National Trust for Historic Preservation in the United States. } \\
{ }^{11} \text { Maryland Environmental Trust. } \\
{ }^{12} \text { Historic Faubourg Corporation (now Preservation Center of New Orleans). } \\
{ }^{13} \text { Vineyard Open Land Foundation. }\end{array}$} \\
\hline
\end{tabular}




\begin{tabular}{|c|c|c|}
\hline $\begin{array}{l}\text { Satullo v. Comm'r, } 67 \text { F.3d 314, } 76 \text { A.F.T.R.2d } 6536 \text { (11th Cir. } \\
\text { 1995), aff'g T.C. Memo. 1993-614 }\end{array}$ & 1985 & $\begin{array}{l}\text { Easements } \\
\text { Atlanta, Inc. }\end{array}$ \\
\hline Great Northern Nekoosa v. U.S., 38 Fed. Cl. 645 (1997) & 1981 & Maine \\
\hline Johnston v. Comm'r, T.C. Memo. 1997-475 & 1989 & $\mathrm{TNC}^{15}$ \\
\hline Browning v. Comm'r, 109 T.C. 303 (1997) & 1990 & $\begin{array}{c}\text { Howard } \\
\text { County, MD }\end{array}$ \\
\hline Strasburg v. Comm'r, T.C. Memo. 2000-94 & $\begin{array}{l}1993 \\
1994\end{array}$ & MLR $^{16}$ \\
\hline \multicolumn{3}{|l|}{2006} \\
\hline Turner v. Comm'r, 126 T.C. 299 (2006) & 1999 & $\begin{array}{c}\text { Fairfax } \\
\text { County, VA }\end{array}$ \\
\hline Ney v. Comm'r, T.C. Summ. Op. 2006-154 (2006) & 2001 & DALPF $^{17}$ \\
\hline $\begin{array}{l}\text { Glass v. Comm'r, } 471 \text { F.3d } 698 \text { (6th Cir. 2006) (Glass II), } \\
\text { aff'g } 124 \text { T.C. } 258 \text { (2005) (Glass I) }\end{array}$ & $\begin{array}{l}1992 \\
1993\end{array}$ & $\mathrm{LTC}^{18}$ \\
\hline Goldsby v. Comm'r, T.C. Memo. 2006-274 & 2000 & MSLT $^{19}$ \\
\hline \multicolumn{3}{|l|}{ 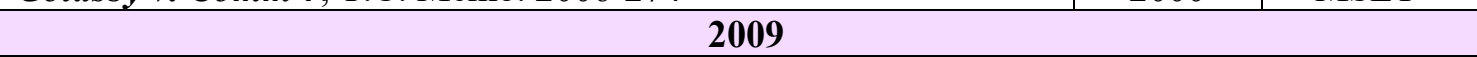 } \\
\hline Bruzewicz v. U.S., 604 F. Supp. 2d 1197 (N.D. Ill. 2009) & 2002 & LPC of IL $^{20}$ \\
\hline Hughes v. Comm'r, T.C. Memo. 2009-94 & 2000 & VLC $^{21}$ \\
\hline Kiva Dunes v. Comm'r, T.C. Memo. 2009-145 & 2002 & NALT $^{22}$ \\
\hline \multicolumn{3}{|l|}{2010} \\
\hline Lord v. Comm'r, T.C. Memo. 2010-196 & 1999 & $\mathrm{LPT}^{23}$ \\
\hline Evans v. Comm'r, T.C. Memo. 2010-207 & 2004 & $\mathrm{CHT}^{24}$ \\
\hline \multicolumn{3}{|l|}{-7000, o } \\
\hline Schrimsher v. Comm'r, T.C. Memo. 2011-71 & 2004 & $\mathrm{AHC}^{25}$ \\
\hline Boltar v. Comm'r, 136 T.C. $326(2011)$ & 2003 & SHLT $^{26}$ \\
\hline 1982 East LLC v. Comm'r, T.C. Memo. 2011-84 & 2004 & $\mathrm{NAT}^{27}$ \\
\hline $\begin{array}{l}\text { Comm'r v. Simmons, } 646 \text { F.3d } 6 \text { (D.C. Cir. 2011) (Simmons II), } \\
\text { aff'g Simmons v. Comm'r, T.C. Memo. 2009-208 (Simmons I) }\end{array}$ & $\begin{array}{l}2003 \\
2004\end{array}$ & $\begin{array}{l}\text { L'Enfant } \\
\text { Trust }\end{array}$ \\
\hline Didonato v. Comm'r, T.C. Memo. 2011-153 & 2004 & $\begin{array}{c}\text { Mercer } \\
\text { County, NJ }\end{array}$ \\
\hline $\begin{array}{l}\text { Herman v. Comm'r, T.C. Bench Op. (Sept. 22, 2011) (Herman II), } \\
\text { addressing remaining issues in T.C. Memo. 2009-205 (Herman I) }\end{array}$ & 2003 & NAT \\
\hline \multicolumn{3}{|l|}{2012} \\
\hline Butler v. Comm'r, T.C. Memo. 2012-72 & $\begin{array}{l}2003 \\
2004\end{array}$ & $\mathrm{CVLT}^{28}$ \\
\hline Dunlap v. Comm'r, T.C. Memo. 2012-126 & 2003 & NAT \\
\hline $\begin{array}{l}15 \text { The Nature Conservancy. } \\
16 \text { Montana Land Reliance. } \\
{ }^{17} \text { Delaware Agricultural Lands Preservation Foundation. } \\
{ }^{18} \text { Little Traverse Conservancy. } \\
{ }^{19} \text { Mississippi Land Trust. } \\
{ }^{20} \text { Landmarks Preservation Council of Illinois } \\
{ }^{21} \text { Valley Land Conservancy (now Black Canyon Regional Land Trust). } \\
22 \text { North American Land Trust. } \\
{ }^{23} \text { Land Preservation Trust. } \\
{ }^{24} \text { Capitol Historic Trust. } \\
{ }^{26} \text { Shirley Heistorical Commission. } \\
{ }^{27} \text { National Architectural Trust, Inc. } \\
{ }^{28} \text { Chattahoochee Vallev Land Trust. }\end{array}$ & & \\
\hline
\end{tabular}




\begin{tabular}{|c|c|c|}
\hline Wall v. Comm'r, T.C. Memo. 2012-169 & 2003 & LPC of IL \\
\hline Averyt v. Comm'r, T.C. Memo. 2012-198 & 2004 & WAT $^{29}$ \\
\hline $\begin{array}{l}\text { Rothman v. Comm'r, T.C. Memo. 2012-218 (Rothman II), } \\
\text { vacating in part T.C. Memo. 2012-163 (Rothman I) }\end{array}$ & 2004 & NAT \\
\hline $\begin{array}{l}\text { Trout Ranch v. Comm'r, } 493 \text { Fed. Appx. } 944 \text { (10th Cir. 2012) } \\
\text { (unpublished) (Trout Ranch II), aff'g T.C. Memo. 2010-283 (Trout } \\
\text { Ranch I) }\end{array}$ & 2003 & $\mathrm{CBLT}^{30}$ \\
\hline Foster v. Comm'r, T.C. Summ. Op. 2012-90 & 2003 & $\begin{array}{c}\text { L'Enfant } \\
\text { Trust }\end{array}$ \\
\hline Irby v. Comm'r, 139 T.C. 371 (2012) & $\begin{array}{l}2003 \\
2004\end{array}$ & $\mathrm{COL}^{31}$ \\
\hline \multicolumn{3}{|l|}{2013} \\
\hline Pollard v. Comm'r, T.C. Memo. 2013-38 & 2003 & $\begin{array}{c}\text { Boulder } \\
\text { County, CO }\end{array}$ \\
\hline $\begin{array}{l}\text { Pesky v. U.S., } 2013 \text { WL } 12249656 \text { (D. Idaho, July 17, 2013) } \\
\text { (unreported), } 112 \text { A.F.T.R.2d 2013-5222 (D. Idaho, July 8, 2013) } \\
\text { (unreported), } 111 \text { A.F.T.R.2d 2013-470 (D. Idaho, Jan. 7, 2013) } \\
\text { (unreported) }\end{array}$ & 2002 & $\mathrm{TNC}$ \\
\hline $\begin{array}{l}\text { Carpenter v. Comm'r, T.C. Memo. 2013-172 (Carpenter II), } \\
\text { denying reconsideration of and supplementing T.C. Memo. 2012-1 } \\
\text { (Carpenter } I)\end{array}$ & 2003 & $\begin{array}{c}\text { Greenlands } \\
\text { Reserve }\end{array}$ \\
\hline $\begin{array}{l}\text { Friedberg v. Comm'r, T.C. Memo. 2013-224 (Friedberg II), } \\
\text { reversing in part and supplementing T.C. Memo. 2011-238 } \\
(\text { Friedberg I) }\end{array}$ & 2003 & NAT \\
\hline Gorra v. Comm'r, T.C. Memo. 2013-254 & 2006 & NAT \\
\hline 61 York Acquisition, LLC v. Comm'r, T.C. Memo. 2013-266 & 2006 & NAT \\
\hline \multicolumn{3}{|l|}{2014} \\
\hline $\begin{array}{l}\text { Esgar Corp. v. Comm'r, } 744 \text { F.3d } 648\left(10^{\text {th }} \text { Cir. 2014) (Esgar II), }\right. \\
\text { aff'g T.C. Memo. 2012-35 (Esgar I) and Tempel v. Comm'r, } 136 \\
\text { T.C. } 341 \text { (2011) }\end{array}$ & 2004 & $\begin{array}{c}\text { Greenlands } \\
\text { Reserve }\end{array}$ \\
\hline Wachter v. Comm'r, 142 T.C. 140 (2014) & $\begin{array}{l}2004 \\
2005 \\
2006\end{array}$ & $\mathrm{AFW}^{32}$ \\
\hline Chandler v. Comm'r, 142 T.C. 279 (2014) & $\begin{array}{l}2004 \\
2005\end{array}$ & NAT \\
\hline $\begin{array}{l}\text { Whitehouse Hotel, LP v. Comm'r, } 755 \text { F.3d } 236\left(5^{\text {th }} \text { Cir. } 2014\right) \\
\text { (Whitehouse IV), aff'g in part and vacating in part } 139 \text { T.C. } 304 \\
\text { (2012) (Whitehouse III), on remand from 615 F.3d } 321 \text { (5th Cir. } \\
\text { 2010) (Whitehouse II), vacating and remanding } 131 \text { T.C. } 112 \\
\text { (2008) (Whitehouse I) }\end{array}$ & 1997 & PANO \\
\hline $\begin{array}{l}\text { Scheidelman v. Comm'r, } 755 \text { F.3d } 148 \text { (2d Cir. 2014) } \\
\text { (Scheidelman IV), aff'g T.C. Memo. 2013-18 (Scheidelman III), on } \\
\text { remand from 682 F.3d } 189 \text { (2d Cir. 2012) (Scheidelman II), } \\
\text { vacating and remanding T.C. Memo. 2010-151 (Scheidelman I) }\end{array}$ & 2004 & NAT \\
\hline
\end{tabular}

${ }^{29}$ Wetlands America Trust.

${ }^{30}$ Crested Butte Land Trust.

${ }^{31}$ Colorado Open Lands.

${ }^{32}$ American Foundation for Wildlife. 


\begin{tabular}{|c|c|c|}
\hline $\begin{array}{l}\text { Seventeen Seventy Sherman Street v. Comm'r, T.C. Memo. 2014- } \\
124\end{array}$ & 2003 & $\begin{array}{c}\text { Historic } \\
\text { Denver }\end{array}$ \\
\hline Schmidt v. Comm'r, T.C. Memo. 2014-159 & 2003 & $\begin{array}{c}\text { El Paso } \\
\text { County, CO }\end{array}$ \\
\hline Zarlengo v. Comm'r, T.C. Memo. 2014-161 & 2005 & NAT \\
\hline Reisner v. Comm'r, T.C. Memo. 2014-230 & 2004 & NAT \\
\hline $\begin{array}{l}\text { Belk v. Comm'r, } 774 \text { F.3d } 221\left(4^{\text {th }} \text { Cir. 2014) (Belk III), }\right. \\
\text { aff'g T.C. Memo } 2013-154(\text { Belk II), denying reconsideration of } \\
\text { and supplementing } 140 \text { T.C. } 1(2013)(\text { Belk })\end{array}$ & 2004 & SMNLT $^{33}$ \\
\hline \multicolumn{3}{|l|}{2015} \\
\hline $\begin{array}{l}\text { Mitchell v. Comm'r, } 775 \text { F.3d } 1243\left(10^{\text {th }} \text { Cir. 2015) (Mitchell III), }\right. \\
\text { aff'g T.C. Memo. 2013-204 (Mitchell II), } \\
\text { denying reconsideration and supplementing } 138 \text { T.C. } 324 \text { (2012) } \\
(\text { Mitchell I) }\end{array}$ & 2003 & $\mathrm{MLC}^{34}$ \\
\hline Balsam Mountain v. Comm'r, T.C. Memo. 2015-43 & 2003 & NALT \\
\hline SWF Real Estate LLC v. Comm'r, T.C. Memo. 2015-63 & 2005 & $\begin{array}{l}\text { Albemarle } \\
\text { County, } \\
\text { VA }^{35}\end{array}$ \\
\hline $\begin{array}{l}\text { Kaufman v. Comm'r, } 784 \text { F.3d. } 56 \text { (1st Cir. 2015) (Kaufman V), } \\
\text { aff'g T.C. Memo. 2014-52 (Kaufman IV), on remand from } 687 \\
\text { F.3d. } 21 \text { (1st Cir. 2012) (Kaufman III), vacating and remanding in } \\
\text { part } 136 \text { T.C. } 294 \text { (2011) (Kaufman II) and } 134 \text { T.C. } 182 \text { (2010) } \\
\text { (Kaufman I) }\end{array}$ & 2003 & NAT \\
\hline Costello v. Comm'r, T.C. Memo. 2015-87 & 2006 & $\begin{array}{c}\text { Howard } \\
\text { County, MD }\end{array}$ \\
\hline $\begin{array}{l}\text { Minnick v. Comm'r, } 796 \text { F.3d } 1156 \text { (9th Cir. 2015) (Minnick III) } \\
\text { and } 611 \text { Fed. Appx. } 477 \text { (9th Cir. 2015) (unpub) (Minnick II), aff'g } \\
\text { T.C. Memo. 2012-345 (Minnick I) }\end{array}$ & 2006 & LTTV $^{36}$ \\
\hline Legg v. Comm'r, 145 T.C. 344 (2015) & 2007 & $\mathrm{CNLT}^{37}$ \\
\hline Atkinson v. Comm'r, T.C. Memo. 2015-236 ${ }^{38}$ & $\begin{array}{l}2003 \\
2005 \\
\end{array}$ & NALT \\
\hline \multicolumn{3}{|l|}{2016} \\
\hline Gemperle v. Comm'r, T.C. Memo. 2016-1 & 2007 & LPC of IL \\
\hline Mecox v. U.S., 117 A.F.T.R.2d 2016-593 (S.D.N.Y.) & 2004 & NAT \\
\hline $\begin{array}{l}\text { Palmer Ranch Holdings, Ltd. v. Comm'r, T.C. Memo. 2016-190 } \\
\text { (Palmer Ranch III), supplementing T.C. Memo 2014-79 (Palmer } \\
\text { Ranch I), aff'd in part, rev'd in part, and remanded, } 812 \text { F.3d } 982 \\
\left(11^{\text {th }} \text { Cir. 2016) (Palmer Ranch II) }\right.\end{array}$ & 2006 & $\begin{array}{c}\text { Sarasota } \\
\text { County, FL }\end{array}$ \\
\hline French v. Comm'r, T.C. Memo. 2016-53 & 2005 & MLR \\
\hline Carroll v. Comm'r, 146 T.C. 196 (2016) & 2005 & $\begin{array}{l}\text { MET \& } \\
\text { LPT }\end{array}$ \\
\hline
\end{tabular}

\footnotetext{
${ }^{33}$ Smokey Mountain National Land Trust.

${ }^{34}$ Montezuma Land Conservancy.

${ }^{35}$ Albemarle County Public Recreational Facilities Authority.

${ }^{36}$ Land Trust of Treasure Valley.

${ }^{37}$ Colorado Natural Land Trust.

${ }^{38}$ On appeal in $4^{\text {th }}$ Circuit.
} 


\begin{tabular}{|c|c|c|}
\hline $\begin{array}{l}\text { Mountanos v. Comm'r, } 651 \text { Fed. Appx. } 592 \text { (9th Cir. 2016) } \\
\text { (unpublished) (Mountanos III), aff'g T.C. Memo. 2013-138 } \\
\text { (Mountanos I), reconsideration denied and opinion supplemented in } \\
\text { T.C. Memo. 2014-38 (Mountanos II). }\end{array}$ & 2005 & GSLC $^{39}$ \\
\hline 15 West $17^{\text {th }}$ St. LLC v. Comm'r, 147 T.C. 557 (2016) & 2007 & NAT \\
\hline McGrady v. Comm'r, T.C. Memo. 2016-233 & 2007 & $\begin{array}{l}\text { Township, } \\
\text { Bucks } \\
\text { County, PA }\end{array}$ \\
\hline \multicolumn{3}{|l|}{2017} \\
\hline Ten Twenty Six Investors v. Comm'r, T.C. Memo. 2017-115 & 2004 & NAT \\
\hline $\begin{array}{l}\text { RP Golf, LLC v. Comm'r, } 860 \text { F.3d } 1096\left(8^{\text {th }} \text { Cir. 2017) (RP Golf }\right. \\
I I I), \text { aff'g T.C. Memo. 2016-80 (RP Golf II) and T.C. Memo. 2012- } \\
282(R P \text { Golf } I)\end{array}$ & 2003 & PCLT $^{40}$ \\
\hline $\begin{array}{l}\text { Partita Partners LLC v. U.S., 266 F.Supp.3d } 683 \text { (S.D.N.Y. 2017) } \\
\text { (Partita Partners II) and } 216 \text { F.Supp.3d } 337 \text { (S.D.N.Y. 2016) } \\
(\text { Partita Partners I) }\end{array}$ & 2008 & NAT \\
\hline Rutkoske v. Comm'r, 149 T.C. No. 6 (2017) & 2009 & ESLC $^{41}$ \\
\hline $\begin{array}{l}\text { Bosque Canyon Ranch, } 867 \text { F.3d } 547 \text { ( } 5^{\text {th }} \text { Cir. 2017) (Bosque } \\
\text { Canyon Ranch II), vacating and remanding T.C. Memo. 2015-130 } \\
\text { (Bosque Canyon Ranch I) }\end{array}$ & $\begin{array}{l}2005 \\
2007\end{array}$ & NALT \\
\hline 310 Retail LLC v. Comm'r, T.C. Memo. 2017-164 & 2005 & LPC of IL \\
\hline Big River Development, LP v. Comm'r, T.C. Memo. 2017-166 & 2005 & PHLF $^{42}$ \\
\hline Salt Point Timber, T.C. Memo. 2017-245 & 2009 & $\mathrm{LBCT}^{43}$ \\
\hline $\begin{array}{l}\text { Graev v. Comm'r, } 149 \text { T.C. No. } 23 \text { (2017) (Graev III), } \\
\text { supplementing vacated opinion in } 147 \text { T.C. } 460 \text { (2016) (Graev II), } \\
\text { supplementing } 140 \text { T.C. } 377 \text { (2013) (Graev I) }\end{array}$ & 2004 & NAT \\
\hline \multicolumn{3}{|l|}{2018} \\
\hline $\begin{array}{l}\text { PBBM-Rose Hill v. Comm'r, Bench Op. (Sept. 9, 2016) (PBBM- } \\
\text { Rose Hill I), aff'd } 900 \text { F.3d } 193\left(5^{\text {th }} \text { Cir. 2018) }(P B B M-\text { Rose Hill }\right. \\
\text { II), petition for rehearing en banc denied, Doc. 00514755950 }\left(5^{\text {th }}\right. \\
\text { Cir., Dec. 11, 2018) }\end{array}$ & 2007 & NALT \\
\hline Harbor Lofts Associates v. Comm'r, 151 T.C. No. 3 (2018) & 2009 & $\mathrm{ENHC}^{44}$ \\
\hline $\begin{array}{l}\text { Champions Retreat Golf Founders, LLC v. Comm'r, } \\
\text { T.C. Memo 2018-146 }\end{array}$ & 2010 & NALT \\
\hline Belair Woods, LLC v. Comm'r, T.C. Memo. 2018-159 & 2009 & GA LT $^{45}$ \\
\hline $\begin{array}{l}\text { Wendell Falls Development v. Comm'r, T.C. Memo. 2018-193 } \\
\text { (Wendell Falls II), denying reconsideration of and supplementing } \\
\text { T.C. Memo. 2018-45 (Wendell Falls I) }\end{array}$ & 2007 & SMNLT \\
\hline $\begin{array}{l}\text { Pine Mountain Preserve, LLLP v. Comm'r, 151 T.C. No. } 14 \\
\text { (2018) (Pine Mountain II) and T.C. Memo. 2018-214 (Pine } \\
\text { Mountain I) }\end{array}$ & $\begin{array}{l}2005 \\
2006 \\
2007\end{array}$ & NALT \\
\hline $\begin{array}{l}{ }^{9} \text { Golden State Land Conservancy. } \\
{ }^{10} \text { Platte County Land Trust. } \\
{ }^{1} \text { Eastern Shore Land Conservancy. } \\
{ }^{2} \text { Pittsburgh History and Landmarks Foundation. } \\
13 \text { Lord Berkeley Conservation Trust. } \\
{ }^{14} \text { Essex National Heritage Commission. } \\
{ }^{5} \text { Georgia Land Trust. }\end{array}$ & & \\
\hline
\end{tabular}




\begin{tabular}{|c|c|c|}
\hline \multicolumn{3}{|l|}{2019} \\
\hline $\begin{array}{l}\text { Palmolive Building Investors, v. Comm'r, } 152 \text { T.C. No. } 4 \text { (2019) } \\
\text { (Palmolive } I I) \text { and } 149 \text { T.C. No. } 380 \text { (2017) (Palmolive I) }\end{array}$ & 2004 & LPC of IL \\
\hline $\begin{array}{l}\text { Roth v.Comm'r, F.3d. , } 2019 \text { WL } 1890976\left(10^{\text {th }} \text { Cir. 2019) }\right. \\
(\text { Roth II), aff'ing T.C. Memo. 2017-248 (Roth I) }\end{array}$ & 2007 & CNLT \\
\hline
\end{tabular}




\section{Appendix D}

Internal Revenue Code $\S 170(f)(11)$

IRC $\S 170$ Charitable, etc., contributions and gifts.

-..

(f) Disallowance of deduction in certain cases and special rules.

-..

(11) Qualified appraisal and other documentation for certain contributions.

(A) In general.

(i) Denial of deduction. In the case of an individual, partnership, or corporation, no deduction shall be allowed under subsection (a) for any contribution of property for which a deduction of more than $\$ 500$ is claimed unless such person meets the requirements of subparagraphs $(B),(C)$, and (D), as the case may be, with respect to such contribution.

(ii) Exceptions.

(I) Readily valued property. Subparagraphs (C) and (D) shall not apply to cash, property described in subsection (e)(1)(B)(iii) or section 1221(a)(1), publicly traded securities (as defined in section $6050 \mathrm{~L}(\mathrm{a})(2)(\mathrm{B}))$, and any qualified vehicle described in paragraph (12)(A)(ii) for which an acknowledgement under paragraph (12)(B)(iii) is provided.

(II) Reasonable cause. Clause (i) shall not apply if it is shown that the failure to meet such requirements is due to reasonable cause and not to willful neglect.

(B) Property description for contributions of more than $\$ 500$. In the case of contributions of property for which a deduction of more than $\$ 500$ is claimed, the requirements of this subparagraph are met if the individual, partnership or corporation includes with the return for the taxable year in which the contribution is made a description of such property and such other information as the Secretary may require. The requirements of this subparagraph shall not apply to a $\mathrm{C}$ corporation which is not a personal service corporation or a closely held C corporation.

(C) Qualified appraisal for contributions of more than $\$ 5,000$. In the case of contributions of property for which a deduction of more than $\$ 5,000$ is claimed, 
the requirements of this subparagraph are met if the individual, partnership, or corporation obtains a qualified appraisal of such property and attaches to the return for the taxable year in which such contribution is made such information regarding such property and such appraisal as the Secretary may require.

(D) Substantiation for contributions of more than $\$ 500,000$. In the case of contributions of property for which a deduction of more than $\$ 500,000$ is claimed, the requirements of this subparagraph are met if the individual, partnership, or corporation attaches to the return for the taxable year a qualified appraisal of such property.

(E) Qualified appraisal and appraiser. For purposes of this paragraph-

(i) Qualified appraisal. The term 'qualified appraisal' means, with respect to any property, an appraisal of such property which-

(I) is treated for purposes of this paragraph as a qualified appraisal under regulations or other guidance prescribed by the Secretary, and

(II) is conducted by a qualified appraiser in accordance with generally accepted appraisal standards and any regulations or other guidance prescribed under subclause (I).

(ii) Qualified appraiser. Except as provided in clause (iii), the term 'qualified appraiser' means an individual who-

(I) has earned an appraisal designation from a recognized professional appraiser organization or has otherwise met minimum education and experience requirements set forth in regulations prescribed by the Secretary,

(II) regularly performs appraisals for which the individual receives compensation, and

(III) meets such other requirements as may be prescribed by the Secretary in regulations or other guidance.

(iii) Specific appraisals. An individual shall not be treated as a qualified appraiser with respect to any specific appraisal unless-

(I) the individual demonstrates verifiable education and experience in valuing the type of property subject to the appraisal, and

(II) the individual has not been prohibited from practicing before the Internal Revenue Service by the Secretary under section 330(c) of title 31, United States Code, at any time during the 3year period ending on the date of the appraisal.

(F) Aggregation of similar items of property. For purposes of determining 
thresholds under this paragraph, property and all similar items of property donated to 1 or more donees shall be treated as 1 property.

(G) Special rule for pass-thru entities. In the case of a partnership or $S$ corporation, this paragraph shall be applied at the entity level, except that the deduction shall be denied at the partner or shareholder level.

(H) Regulations. The Secretary may prescribe such regulations as may be necessary or appropriate to carry out the purposes of this paragraph, including regulations that may provide that some or all of the requirements of this paragraph do not apply in appropriate cases. 
system. The Department has written the regulation so as to minimize litigation and provide a clear legal standard for affected conduct, and the Department has reviewed the regulation carefully to eliminate drafting errors and ambiguities.

\section{Executive Order 13211}

This rule is not subject to E.O. 13211, because it will not have a significant adverse effect on the supply, distribution, or use of energy.

\section{Plain Language}

The Department drafted this IFR in plain language.

\section{List of Subjects in 20 CFR Part 641}

Aged, Employment, Government contracts, Grant programs-labor, Privacy, Reporting and recordkeeping requirements.

- Accordingly, the IFR amending 20 CFR part 641 which was published at 82 FR 56869 on December 1, 2017, is adopted as final without change.

Rosemary Lahasky,

Deputy Assistant Secretary for Employment and Training, Labor.

[FR Doc. 2018-16216 Filed 7-27-18; 8:45 am] BILLING CODE 4510-FN-P

\section{DEPARTMENT OF THE TREASURY}

Internal Revenue Service

26 CFR Parts 1 and 602

[TD 9836]

RIN 1545-BH62

\section{Substantiation and Reporting Requirements for Cash and Noncash Charitable Contribution Deductions}

AGENCY: Internal Revenue Service (IRS), Treasury.

ACTION: Final regulations.

SUMmARY: These final regulations provide guidance concerning substantiation and reporting requirements for cash and noncash charitable contributions. The final regulations reflect the enactment of provisions of the American Jobs Creation Act of 2004 and the Pension Protection Act of 2006. These regulations provide guidance to individuals, partnerships, and corporations that make charitable contributions.

DATES: Effective date: These regulations are effective on July 30, 2018.

Applicability dates: For dates of applicability, see $\S \S 1.170 \mathrm{~A}-1(\mathrm{k})$,
1.170A-14(j), 1.170A-15(h), 1.170A16(g), 1.170A-17(c), 1.170A-18(d), 1.664-1(f), and 1.6050L-1(h).

FOR FURTHER INFORMATION CONTACT: Charles Gorham at (202) 317-7003 (not a toll-free number).

\section{SUPPLEMENTARY INFORMATION:}

\section{Paperwork Reduction Act}

The collections of information contained in these final regulations have been reviewed and approved by the Office of Management and Budget in accordance with the Paperwork Reduction Act of 1995 (44 U.S.C. 3507(d)) under control number 15451953.

The collections of information in these final regulations are in $\S \S 1.170 \mathrm{~A}-$ 15(a) and (d)(1); 1.170A-16(a), (b), (c), (d), (e), and (f); and 1.170A-18(a)(2) and (b). These collections of information are required to obtain a benefit and will enable the IRS to determine if a taxpayer is entitled to a claimed deduction for a charitable contribution.

An agency may not conduct or sponsor, and a person is not required to respond to, a collection of information unless it displays a valid control number.

Books or records relating to a collection of information must be retained as long as their contents may become material in the administration of any internal revenue law. Generally, tax returns and return information are confidential, as required by section 6103.

\section{Background}

This document contains amendments to the Income Tax Regulations, 26 CFR parts 1 and 602, relating to substantiating and reporting deductions for charitable contributions under section 170 of the Internal Revenue Code. These final regulations reflect amendments to section 170 made by section 883 of the American Jobs Creation Act of 2004, Public Law 108357 (118 Stat. 1418, 1631) (Jobs Act), and sections 1216, 1217, and 1219 of the Pension Protection Act of 2006, Public Law 109-280 (120 Stat. 780, 1079-83) (PPA), which added new rules for substantiating charitable contributions. The final regulations also update crossreferences to the section 170 regulations in other regulations.

Section 170(f)(8), which has been in the Code since 1993, provides that no deduction shall be allowed for any contribution of $\$ 250$ or more, cash or noncash, unless the taxpayer substantiates the contribution with a contemporaneous written acknowledgment of the contribution by the donee organization. The contemporaneous written acknowledgment must include: (1) The amount of cash and a description (but not value) of any property other than cash contributed; (2) a statement of whether the donee organization provided any goods or services in consideration, in whole or in part, for any such cash or property; and (3) a description and good faith estimate of the value of any such goods or services or, if such goods or services consist solely of intangible religious benefits, a statement to that effect.

Section 170(f)(11), as added by section 883 of the Jobs Act, restates, in part, section 155(a) of the Deficit Reduction Act of 1984 and contains reporting and substantiation requirements relating to the allowance of deductions for noncash charitable contributions. Under section 170(f)(11)(C), taxpayers are required to obtain a qualified appraisal for donated property for which a deduction of more than $\$ 5,000$ is claimed.

Under section 170(f)(11)(D), a qualified appraisal must be attached to any tax return claiming a deduction of more than $\$ 500,000$. Section 170(h)(4)(B), as added by section 1213 of the PPA, adds the requirement that a qualified appraisal must be included with the taxpayer's return for the taxable year of the contribution for any contribution of a qualified real property interest that is a restriction as to the exterior of a building described in section $170(\mathrm{~h})(4)(\mathrm{C})(\mathrm{ii})$.

Section 170(f)(11)(E), as amended by section 1219 of the PPA, provides statutory definitions of qualified appraisal and qualified appraiser for appraisals prepared with respect to returns filed after August 17, 2006.

Section 170(f)(11)(E)(i) provides that the term qualified appraisal means an appraisal that is (1) treated as a qualified appraisal under regulations or other guidance prescribed by the Secretary, and (2) conducted by a qualified appraiser in accordance with generally accepted appraisal standards and any regulations or other guidance prescribed by the Secretary.

Section 170(f)(11)(E)(ii) provides that the term qualified appraiser means an individual who (1) has earned an appraisal designation from a recognized professional appraiser organization or has otherwise met minimum education and experience requirements set forth in regulations prescribed by the Secretary, (2) regularly performs appraisals for which the individual receives compensation, and (3) meets such other requirements as may be prescribed by the Secretary in regulations or other 
guidance. Section 170(f)(11)(E)(iii) provides that an individual will not be treated as a qualified appraiser with respect to any specific appraisal unless that individual (1) demonstrates verifiable education and experience in valuing the type of property subject to the appraisal, and (2) has not been prohibited from practicing before the IRS by the Secretary under section 330 (c) of Title 31 of the United States Code at any time during the 3-year period ending on the date of the appraisal.

On October 19, 2006, the Treasury Department and the IRS released Notice 2006-96, 2006-2 CB 902 (see $\S 601.601(\mathrm{~d})(2)(\mathrm{ii})(b))$, which provides transitional guidance on the definitions of qualified appraisal and qualified appraiser that apply on and after the effective date of the PPA definitions.

Section 170(f)(16) as added by section 1216 of the PPA generally provides that no deduction is allowed for a contribution of clothing or a household item unless the clothing or household item is in good used condition or better.

Section 170(f)(17) as added by section 1217 of the PPA imposes a recordkeeping requirement for all cash contributions, regardless of amount. Specifically, section 170(f)(17) requires a donor to maintain as a record of any cash, check, or other monetary gift (1) a bank record, or (2) a written communication from the donee. The record must show the name of the donee organization, the date of the

contribution, and the amount of the contribution.

On December 2, 2006, the Treasury Department and the IRS released Notice 2006-110, 2006-2 CB 1127 (see $\S 601.601(\mathrm{~d})(2)(\mathrm{ii})(b))$, which provides rules under section $170(f)(17)$ for substantiating charitable contributions made by payroll deduction.

On January 8, 2008, the Treasury Department and the IRS released Notice 2008-16, 2008-1 CB 315 (see $\S 601.601(\mathrm{~d})(2)(\mathrm{ii})(b))$, which provides rules under section 170(f)(17) for substantiating a one-time, lump-sum charitable contribution of a cash, check, or other monetary gift made through the Combined Federal Campaign (CFC) or a similar program. Taxpayers may rely on Notice 2006-96, Notice 2006-110, and Notice 2008-16 prior to the effective date of these final regulations.

On August 7, 2008, the Treasury Department and the IRS provided guidance on complying with section 170 as amended by the Jobs Act and the PPA in a notice of proposed rulemaking (REG-140029-07) in the Federal Register (73 FR 45908). The Treasury Department and the IRS received comments responding to the notice of proposed rulemaking, and a public hearing was held on January 23, 2009. Copies of the comments received are available for public inspection at www.regulations.gov or upon request. After consideration of the comments received, the Treasury Department and the IRS adopt the proposed regulations as revised by this Treasury decision. The revisions are discussed in this preamble.

\section{Explanation of Provisions and Summary of Comments}

The final regulations implement changes made by the Jobs Act and PPA to the substantiation and reporting rules for charitable contributions under section 170. The final regulations set forth the substantiation requirements for contributions of more than $\$ 500$ under section 170(f)(11)(B) through (D) (added by the Jobs Act); the new definitions of qualified appraisal and qualified appraiser applicable to noncash contributions under section 170(f)(11)(E) (added by the PPA); substantiation requirements for contributions of clothing and household items under section 170(f)(16) (added by the PPA); and recordkeeping requirements for all cash contributions under section 170(f)(17) (added by the PPA).

In addition, these final regulations amend the heading of $\S 1.170 \mathrm{~A}-13$ to alert readers to the updated regulations. The final regulations also update crossreferences to the section 170 regulations in other regulations.

\section{Cash, Check, or Other Monetary Gift Substantiation Requirements}

Section 1.170A-15 implements the requirements of section $170(f)(17)$ for cash, check, or other monetary gift contributions, as added by the PPA, and clarifies that these rules supplement the substantiation rules in section $170(\mathrm{f})(8)$.

\section{A. Contributions Made to a Distributing Organization}

A donor may make a charitable contribution of cash, check, or other monetary gift to an organization that collects contributions and distributes them to ultimate recipient organizations (pursuant to the donor's instructions or otherwise). The final regulations adopt the general rule of the proposed regulations that treats as a donee for purposes of sections 170(f)(8) and 170(f)(17) an organization described in section 170(c) or a Principal Combined Fund Organization (PCFO) for purposes of the Combined Federal Campaign (CFC) and acting in that capacity. The $\mathrm{CFC}$ is a workplace giving campaign established by Executive Order 10728 , as amended by Executive Orders 10927, 12353, and 12404, and administered by the United States Office of Personnel Management (OPM). A PCFO

administers the local campaign and acts as a fiscal agent for the CFC.

\section{Blank Pledge Card Is Not}

\section{Substantiation}

Some commenters asked whether a blank pledge card provided by a donee organization but filled out by the donor constitutes adequate substantiation for a contribution of cash to a distributing organization. Section 170(f)(17) requires a taxpayer to maintain as a record of a contribution of a cash, check, or other monetary gift either a bank record or a written communication from the donee that shows the name of the donee organization, the date of the contribution, and the amount of the contribution. The proposed and final regulations at $\S 1.170 \mathrm{~A}-15(\mathrm{~b})(2)$ provide that a bank record includes a statement

from a financial institution, an electronic fund transfer receipt, a canceled check, a scanned image of both sides of a canceled check obtained from a bank website, or a credit card statement. In addition, the proposed and final regulations provide that a written communication includes an email. Because a blank pledge card provided by the donee organization to a donor does not show the information required under section 170(f)(17), it is not sufficient substantiation for a cash, check, or other monetary gift.

\section{Name of Donee for Purposes of CFC}

One commenter noted that because the CFC generally does not include the name of the donee organization on its pledge cards, and a PCFO for purposes of the CFC often is a potential ultimate recipient of a contribution to the $\mathrm{CFC}$, including the name of the PCFO on the pledge card could unduly influence donors to contribute to the PCFO rather than to other eligible donees. The commenter asked that the name of the local CFC campaign be treated as the name of the donee organization. The Treasury Department and the IRS agree with this comment. Accordingly,

$\S 1.170 \mathrm{~A}-15(\mathrm{~d})(2)(\mathrm{ii})$ provides that the name of the local CFC may be used instead of the name of the PCFO and may be treated as the donee organization for purposes of sections $170(f)(8)$ and $170(f)(17)$ and $\S 1.170 \mathrm{~A}-$ 15(d)(1)(ii).

\section{B. Compliance With $170(f)(8)$ and $170(f)(17)$ in a Single Document}

Some commenters asked if a single written acknowledgment can be used to 
satisfy the substantiation rules under sections $170(f)(8)$ and $170(f)(17)$. Section $170(\mathrm{f})(8)$ does not require that a contemporaneous written acknowledgment by the donee organization include the date of the contribution. In addition, section $170(f)(17)$ does not require that a written communication from the donee include a statement of whether any goods or services were provided in exchange for the contribution. Although there are different requirements under sections 170(f)(8) and 170(f)(17), §1.170A15(a)(3) of the final regulations provides that a single written acknowledgment that satisfies all substantiation requirements under both sections $170(f)(8)$ and $170(f)(17)$ is adequate substantiation for contributions of a cash, check, or other monetary gift.

\section{Noncash Substantiation \\ Requirements}

Section 1.170A-16 implements the requirements of section $170(f)(11)$ for noncash contributions, as added by the Jobs Act, and clarifies that these rules are in addition to the requirements in section $170(f)(8)$.

Proposed and final §1.170A-16 provide that a donor who claims a deduction for a noncash contribution of less than $\$ 250$ is required only to obtain a receipt from the donee or keep reliable records. A donor who claims a noncash contribution of at least $\$ 250$ but not more than $\$ 500$ is required only to obtain a contemporaneous written acknowledgment, as provided under section $170(\mathrm{f})(8)$ and $\S 1.170 \mathrm{~A}-13(\mathrm{f})$. For claimed noncash contributions of more than $\$ 500$ but not more than $\$ 5,000$, the donor must obtain a contemporaneous written acknowledgment and must also file a completed Form 8283 (Section A), "Noncash Charitable Contributions," with the return on which the deduction is claimed. For claimed noncash contributions of more than $\$ 5,000$, in addition to a contemporaneous written acknowledgment, the donor generally must obtain a qualified appraisal and must also complete and file either Section A or Section B of Form 8283 (depending on the type of property contributed) with the return on which the deduction is claimed. For claimed noncash contributions of more than $\$ 500,000$, the donor must also attach a copy of the qualified appraisal to the return for the taxable year in which the contribution is made.

Section 170(f)(11)(F) provides that for purposes of the $\$ 500, \$ 5,000$, and $\$ 500,000$ thresholds in section 170(f)(11), similar items contributed during the taxable year are treated as one property. In determining whether a contribution meets the $\$ 250$ threshold, $\S 1.170 \mathrm{~A}-13(\mathrm{f})(1)$ provides that separate contributions made during the tax year, regardless of whether the sum of those contributions equal or exceed $\$ 250$, are not combined. The proposed and final regulations also provide that the requirements for substantiation that must be submitted with a return also apply to the return for any carryover year under section $170(d)$.

\section{A. Reasonable Cause Exception}

In light of recent case law (see Crimi v. Commissioner, T.C. Memo. 2013-51), the paragraph relating to the reasonable cause exception set forth in proposed regulation $\S 1.170 \mathrm{~A}-16(\mathrm{f})(6)$ has been deleted from the final regulations because it is inconsistent with the Tax Court's position. In Crimi, the IRS argued that there was no qualified appraisal. The Tax Court discussed the doctrine of substantial compliance with respect to the qualified appraisal regulation, but stated that it was unnecessary to decide whether it was applicable to the petitioners' case because they established that the failure was due to reasonable cause.

Specifically, the court stated that a reasonable cause inquiry is "inherently a fact-intensive one, and facts and circumstances must be judged on a caseby-case basis." Id. at * 99 . The court found that petitioners reasonably and in good faith relied on their long-time certified public accountant's advice that their appraisal met all the legal requirements to claim the deduction. Thus, the final regulations do not contain a standard for the reasonable cause exception.

\section{B. Appraiser Privacy Concerns}

A number of commenters expressed concern over appraisers' privacy if the appraiser's social security number is required on qualified appraisals and Forms 8283 (Section B). This concern was addressed by the proposed regulations. Both the proposed and final regulations require an appraiser to use a taxpayer identification number on an appraisal, but that number does not need to be the appraiser's social security number. An appraiser may use an employer identification number, which may be obtained by: (1) Applying on the IRS website (www.regulationsgov); or (2) filing a completed Form SS-4,

Application for Employer Identification Number, by mail or by fax. The IRS has modified the instructions to Form 8283 to make clear that an appraiser may use either a social security number or an employer identification number.
C. Form 8283 Is Not a Contemporaneous Written Acknowledgment

One commenter asked whether a Form 8283 can satisfy the requirement for a contemporaneous written acknowledgment under section $170(f)(8)$. Although no format is prescribed for a contemporaneous written acknowledgment (for example, an email may qualify), a

contemporaneous written acknowledgment of a contribution by the donee organization must contain all of the information required by section 170(f)(8)(B). Moreover, section $170(f)(8)(A)$ states that the acknowledgment is made "by the donee organization." Only Section B, part IV of Form 8283, completed for property valued at over $\$ 5,000$, is a donee acknowledgment, and this acknowledgment only contains some of the information required by section 170(f)(8)(B). Accordingly, even a fullycompleted Form 8283 does not satisfy the requirements of section $170(f)(8)$.

\section{Form 8283 (Section B) Provided to Donee}

Another commenter suggested that the Form 8283 (Section B) should be required to be fully completed, including the appraiser information and the appraised or claimed value of the property, before the donor obtains the donee's signature. Section 1.170A16(d)(5)(iii) of the proposed regulations provides that specific portions of the Form 8283 (Section B) must be completed before it is signed by the donee, but that the Form 8283 (Section B) does not need to contain certain other information, such as the appraiser information and the appraised or claimed value of the property, before the donee signs the form. Regardless of any benefits that may result from additional information sharing, the public should have the opportunity to comment on any proposed requirement to share additional information with the donee. Accordingly, the final regulations adopt the proposed regulation language without adoption of this suggestion.

\section{E. Attaching Appraisal to Carryover Year Returns}

One commenter suggested deleting the requirement in the regulations to attach an appraisal to the tax returns for carryover years. Because the need for the IRS to have the appraisal attached to each return reflecting a contribution in excess of $\$ 500,000$ outweighs the burden on taxpayers to supply it, the final regulations retain this requirement. Accordingly, if the appraisal is required to be attached to the return for the 
contribution year, it must also be attached to the returns for the carryover years.

\section{New Requirements for Qualified Appraisals and Qualified Appraisers}

As prescribed in section 170(f)(11)(E), as amended by the PPA, $\S 1.170 \mathrm{~A}-17$ of the proposed and final regulations provides definitions for qualified appraisal and qualified appraiser.

\section{A. Transitional Rule}

One commenter suggested that a transitional rule be included for $\S 1.170 \mathrm{~A}-17$ because additional time may be needed to meet the education and experience requirements in $\S 1.170 \mathrm{~A}-17$ for qualified appraisers. In order to provide appraisers with a reasonable amount of time to meet the new education and experience requirements, the final rules under $\S 1.170 \mathrm{~A}-17$ apply only to contributions made on or after January 1, 2019.

\section{B. Definition of Generally Accepted Appraisal Standards}

Section 170(f)(11)(E)(i)(II) provides that the term qualified appraisal means an appraisal that is conducted by a qualified appraiser in accordance with generally accepted appraisal standards. Generally accepted appraisal standards are defined in the proposed regulations at $\S 1.170 \mathrm{~A}-17(\mathrm{a})(2)$ as the "substance and principles of the Uniform Standards of Professional Appraisal Practice [USPAP], as developed by the Appraisal Standards Board of the Appraisal Foundation." Several commenters recommended that the final regulations require appraisal documents to be prepared "in accordance with USPAP" and not merely in accordance with the "substance and principles of USPAP.", Other commenters indicated that strict compliance with USPAP would eliminate use of all other appraisal standards, including some that are generally accepted in the appraisal industry. The Treasury Department and the IRS agree that it is beneficial to provide some flexibility by requiring conformity with appraisal standards that are consistent with the substance and principles of USPAP rather than requiring that all appraisals be prepared strictly in accordance with USPAP. Accordingly, the final regulations do not adopt the recommendation to require strict compliance with USPAP and retain the requirement of consistency with the substance and principles of USPAP.
C. Education and Experience Requirement for Qualified Appraisers

Section 170(f)(11)(E)(ii)(I) and (iii)(I) and $\S 1.170 \mathrm{~A}-17(\mathrm{~b})$ of the proposed regulations provide that a qualified appraiser is an individual with verifiable education and experience in valuing the type of property for which the appraisal is performed. Some commenters reiterated suggestions made in response to Notice 2006-96 that the final regulations interpret the requirement in section $170(f)(11)(E)$ that a qualified appraiser have verifiable "education and experience" as requiring verifiable "education or experience.” The Treasury Department and the IRS did not adopt this suggestion in the proposed regulations, and do not do so in the final regulations, because it would be contrary to the clear language of the statute.

Section 1.170A-17(b)(4) of the proposed regulations requires an appraiser to specify in the appraisal the appraiser's education and experience in valuing the type of property and to make a declaration in the appraisal that, because of the appraiser's education and experience, the appraiser is qualified to make appraisals of the type of property being valued. A commenter suggested that, to meet the "verifiable" requirement in $\$ 1.170 \mathrm{~A}-17(\mathrm{~b})$, the appraiser should be required to specify in the appraisal only that the appraiser is a qualified appraiser under $\S 1.170 \mathrm{~A}-$ 17(b) and that the appraisal was prepared in accordance with the substance and principles of USPAP. The general statement of qualification suggested by the commenter does not demonstrate, as required under section 170(f)(11)(E)(iii)(I), that the appraiser has verifiable education and experience that qualifies the appraiser to prepare the appraisal for that type of property. Accordingly, the final regulations do not adopt this suggestion.

\section{Parity Between “Designation” and "Education and Experience"}

Section 1.170A-17(b)(2)(i) of the proposed regulations provides that an individual is treated as having education and experience in valuing the type of property if, as of the date the individual signs the appraisal, the individual has satisfied the following requirements: (A) Successfully completed professional or college-level coursework in valuing the type of property and has two or more years of experience in valuing the type of property; or (B) earned a recognized appraiser designation for the type of property. One commenter suggested that it is much more difficult to earn a designation from a generally recognized professional appraiser organization under $\$ 1.170 \mathrm{~A}-17(\mathrm{~b})(2)(\mathrm{i})(\mathrm{B})$ than to satisfy the education and experience requirements under $\S 1.170 \mathrm{~A}-$ 17(b)(2)(i)(A). The commenter suggested that the education and experience requirements be made more stringent. In enacting section 170(f)(11)(E), Congress intended to improve the accuracy of deductions claimed for noncash contributions by requiring qualified appraisers to meet more stringent qualification standards, including by requiring that both education and experience requirements be met. See H.R. Rep. No. 108-548, pt. 1, at 356 (2004). The requirements for education and experience in the proposed regulations are sufficiently stringent as intended by Congress. Accordingly, the final regulations do not adopt this suggestion and retain without modification the requirements for education and experience in the proposed regulations.

\section{E. Satisfying Verifiable Education Requirement}

Section 170(f)(11)(E)(iii)(I) requires verifiable education and experience in valuing the type of property subject to the appraisal. Section 1.170A17(b)(2)(i)(A) of the proposed regulations provides that an individual is treated as having education and experience in valuing the type of property if, as of the date the individual signs the appraisal, the individual has successfully completed (for example, received a passing grade on a final examination) professional or collegelevel coursework in valuing the type of property, and has two or more years of experience in valuing the type of property. One commenter asked whether attendance at a training event that does not include a final examination meets the requirement of successful completion of coursework. The reference to a passing grade on a final examination in $\S 1.170 \mathrm{~A}-$ 17(b)(2)(i)(A) is merely an example of what is considered successful completion of professional or collegelevel coursework, and other evidence of successful completion may be sufficient. However, mere attendance at a training event is not sufficient, and evidence of successful completion of coursework is necessary under the final regulations.

\section{F. Education Provided by Trade Organization}

Two commenters pointed out that, in addition to generally recognized professional appraiser organizations, a generally recognized professional trade organization may provide coursework 
that satisfies the requirement for verifiable education in valuing the type of property under $\S 1.170 \mathrm{~A}-$ 17(b)(2)(i)(A) and (ii)(B). The Treasury Department and the IRS agree with this comment, and the final regulations provide that an appraiser also can satisfy $\S 1.170 \mathrm{~A}-17(\mathrm{~b})(2)(\mathrm{i})(\mathrm{A})$ and (ii)(B) by successfully completing coursework in valuing the type of property from a generally recognized professional trade organization.

\section{G. Examples of Generally Recognized} Professional Appraiser Organizations

Some commenters objected to the references in the proposed regulations to designations conferred by one particular organization as examples of recognized appraiser designations. The Treasury Department and the IRS do not require or prefer the designation of any particular appraiser organization, and, therefore, the final regulations do not contain examples of any designations.

\section{Additional Comments}

A number of commenters requested that the Treasury Department and the IRS provide that the final regulations apply to charitable contributions for all federal tax purposes, including estate and gift tax. These regulations are promulgated under Jobs Act and PPA provisions that apply only to income tax deductions for charitable contributions under section 170 . No substantive changes were made to the proposed regulations in response to these comments because these comments were beyond the scope of the proposed regulations.

Some commenters suggested that appraisers be allowed to use certain IRS valuation tables, such as those for charitable remainder trusts, other remainder interests in property, and life insurance policies, instead of a qualified appraisal. These tables may be used to value property in certain other contexts, but they do not necessarily provide a fair market value of the property contributed. Therefore, these tables are not acceptable substitutes for a qualified appraisal to substantiate deductions for charitable contributions under section 170.

Another commenter suggested that taxpayers should not be required to substantiate their charitable contribution deduction with a qualified appraisal when they purchase medical equipment, such as a Magnetic

Resonance Imaging (MRI) machine, and donate the equipment to a qualified organization. The purchase price of the medical equipment may differ from its fair market value. A qualified appraisal prepared by a qualified appraiser is required to determine the fair market value at the time of contribution.

Therefore, no changes were made to the proposed regulations in response to this comment.

\section{Effect on Other Documents}

Notice 2006-96 provides transitional guidance on the definitions of qualified appraisal and qualified appraiser under section 170(f)(11). Notice 2006-110 provides transitional guidance under section 170(f)(17) for substantiating charitable contributions made by payroll deduction. Notice 2008-16 provides transitional guidance under section $170(f)(17)$ for substantiating a one-time, lump-sum charitable contribution of a cash, check, or other monetary gift made through the CFC or a similar program. All three notices provide that taxpayers may rely on the notices until final regulations are effective. Accordingly, Notice 2006-110 and Notice 2008-16 are obsolete as of July 30, 2018 and Notice 2006-96 is obsolete as of January 1, 2019.

\section{Applicability Dates}

In general, §§ 1.170A-15, 1.170A-16, and 1.170A-18 apply to contributions made after July 30,2018 . Section 1.170A-17 applies to contributions made on or after January 1, 2019. Taxpayers are reminded that the effective dates of the Jobs Act and the PPA relating to substantiating and reporting charitable contributions precede the effective date of these final regulations, and the Jobs Act and the PPA apply in accordance with their applicability dates. See Notice 2006-96.

\section{Special Analyses}

This regulation is not subject to review under section 6(b) of Executive Order 12866 pursuant to the Memorandum of Agreement (April 11, 2018) between the Department of the Treasury and the Office of Management and Budget regarding review of tax regulations. Further it is hereby certified that these regulations will not have a significant economic impact on a substantial number of small entities. Accordingly, a Regulatory Flexibility Analysis under the Regulatory Flexibility Act (5 U.S.C. chapter 6) is not required. Although this rule could affect a substantial number of small entities, any economic impact is expected to be minimal. The final rule provides clarifications and simplifications to the existing substantiation and reporting requirements for charitable contributions and are designed to reduce the burden on taxpayers. Further, any substantiation and reporting rules contained in these final regulations that are in addition to the rules in current regulations reflect statutory substantiation and reporting requirements. Pursuant to section 7805(f) of the Internal Revenue Code, the notice of proposed rulemaking preceding this regulation was submitted to the Chief Counsel for Advocacy of the Small Business Administration for comment on its impact on small business, and no comments were received.

\section{Drafting Information}

The principal author of these regulations is Charles Gorham of the Office of Associate Chief Counsel (Income Tax and Accounting). Other personnel from the Treasury Department and the IRS participated in their development.

\section{List of Subjects}

\section{CFR Part 1}

Income taxes, Reporting and recordkeeping requirements.

\section{CFR Part 602}

Reporting and recordkeeping requirements.

\section{Adoption of Amendments to the Regulations}

Accordingly, 26 CFR parts 1 and 602 are amended as follows:

\section{PART 1-INCOME TAXES}

- Paragraph 1. The authority citation for part 1 amended by adding sectional authorities for §§ 1.170A-15 through 1.170A-18 in numerical order to read in part as follows:

Authority: 26 U.S.C. 7805 * * *

$\S 1.170 \mathrm{~A}-15$ also issued under 26 U.S.C. 170(a)(1).

$\S 1.170 \mathrm{~A}-16$ also issued under 26 U.S.C. 170(a)(1) and 170(f)(11).

$\S 1.170 \mathrm{~A}-17$ also issued under 26 U.S.C. 170(a)(1) and 170(f)(11).

$\S 1.170 \mathrm{~A}-18$ also issued under 26 U.S.C. $170(\mathrm{a})(1)$

* * * * *

$\S \S 1.170-0,1.170-1$, and 1.170-2 [Removed]

- Par. 2. Sections 1.170-0, 1.170-1, and 1.170-2 are removed.

- Par. 3. Section 1.170A-1 is amended by revising the third sentence of paragraph (a) and adding two sentences to the end of paragraph $(\mathrm{k})$ to read as follows:

§1.170A-1 Charitable, etc., contributions and gifts; allowance of deduction.

(a) *** For rules relating to record keeping and return requirements in 
support of deductions for charitable contributions (whether by an itemizing or nonitemizing taxpayer), see

$\S \S 1.170 \mathrm{~A}-13,1.170 \mathrm{~A}-14,1.170 \mathrm{~A}-15$, 1.170A-16, 1.170A-17, and

$1.170 \mathrm{~A}-18 . * * *$

* $* * * * *$

$(k) * * *$ The third sentence of paragraph (a) applies as provided in the sections referenced in that sentence.

Par. 4. Section 1.170A-13 is amended by revising the heading to read as follows:

\section{\$1.170A-13 Recordkeeping and return requirements for deductions for charitable contributions.}

Par. 5. Section 1.170A-14 is amended by revising paragraphs (i) and (j) to read as follows:

\section{\$1.170A-14. Qualified conservation contributions.}

(i) Substantiation requirement. If a taxpayer makes a qualified conservation contribution and claims a deduction, the taxpayer must maintain written records of the fair market value of the underlying property before and after the donation and the conservation purpose furthered by the donation, and such information shall be stated in the taxpayer's income tax return if required by the return or its instructions. See also $\S 1.170 \mathrm{~A}-13(\mathrm{c})$ (relating to substantiation requirements for deductions in excess of $\$ 5,000$ for charitable contributions made on or before July 30, 2018); § 1.170A-16(d) (relating to substantiation of charitable contributions of more than $\$ 5,000$ made after July 30, 2018); §1.170A-17 (relating to the definitions of qualified appraisal and qualified appraiser for substantiation of contributions made on or after January 1, 2019); and section 6662 (relating to the imposition of an accuracy-related penalty on underpayments). Taxpayers may rely on the rules in $\S 1.170 \mathrm{~A}-16(\mathrm{~d})$ for contributions made after June 3, 2004, or appraisals prepared for returns or submissions filed after August 17, 2006. Taxpayers may rely on the rules in $\S 1.170 \mathrm{~A}-17$ for appraisals prepared for returns or submissions filed after August 17, 2006.

(j) Effective/applicability dates. Except as otherwise provided in $\S 1.170 \mathrm{~A}-14(\mathrm{~g})(4)$ (ii) and $\S 1.170 \mathrm{~A}-14(\mathrm{i})$, this section applies only to contributions made on or after December 18, 1980.

Par. 6. Section 1.170A-15 is added to read as follows:
\$1.170A-15 Substantiation requirements for charitable contribution of a cash, check, or other monetary gift.

(a) In general-(1) Bank record or written communication required. No deduction is allowed under sections 170(a) and 170(f)(17) for a charitable contribution in the form of a cash, check, or other monetary gift, as described in paragraph (b)(1) of this section, unless the donor substantiates the deduction with a bank record, as described in paragraph (b)(2) of this section, or a written communication, as described in paragraph (b)(3) of this section, from the donee showing the name of the donee, the date of the contribution, and the amount of the contribution.

(2) Additional substantiation required for contributions of $\$ 250$ or more. No deduction is allowed under section 170 (a) for any contribution of $\$ 250$ or more unless the donor substantiates the contribution with a contemporaneous written acknowledgment, as described in section 170(f)(8) and $\S 1.170 \mathrm{~A}-13(\mathrm{f})$, from the donee.

(3) Single document may be used. The requirements of paragraphs (a)(1) and (2) of this section may be met by a single document that contains all the information required by paragraphs (a)(1) and (2) of this section, if the document is obtained by the donor no later than the date prescribed by paragraph (c) of this section.

(b) Terms-(1) Monetary gift includes a transfer of a gift card redeemable for cash, and a payment made by credit card, electronic fund transfer (as described in section 5061(e)(2)), an online payment service, or payroll deduction.

(2) Bank record includes a statement from a financial institution, an electronic fund transfer receipt, a canceled check, a scanned image of both sides of a canceled check obtained from a bank website, or a credit card statement.

(3) Written communication includes email.

(c) Deadline for receipt of substantiation. The substantiation described in paragraph (a) of this section must be received by the donor on or before the earlier of-

(1) The date the donor files the original return for the taxable year in which the contribution was made; or

(2) The due date, including any extension, for filing the donor's original return for that year.

(d) Special rules-(1) Contributions made by payroll deduction. In the case of a charitable contribution made by payroll deduction, a donor is treated as meeting the requirements of section 170(f)(17) and paragraph (a) of this section if, no later than the date described in paragraph (c) of this section, the donor obtains-

(i) A pay stub, Form W-2, "Wage and Tax Statement,” or other employerfurnished document that sets forth the amount withheld during the taxable year for payment to a donee; and

(ii) A pledge card or other document prepared by or at the direction of the donee that shows the name of the donee.

(2) Distributing organizations as donees. The following organizations are treated as donees for purposes of section 170(f)(17) and paragraph (a) of this section, even if the organization (pursuant to the donor's instructions or otherwise) distributes the amount received to one or more organizations described in section 170(c):

(i) An organization described in section 170 (c).

(ii) An organization described in 5 CFR 950.105 (a Principal Combined Fund Organization (PCFO) for purposes of the Combined Federal Campaign (CFC)) and acting in that capacity. For purposes of the requirement for a written communication under section 170(f)(17), if the donee is a PCFO, the name of the local CFC campaign may be treated as the name of the donee organization.

(e) Substantiation of out-of-pocket expenses. Paragraph (a)(1) of this section does not apply to a donor who incurs unreimbursed expenses of less than $\$ 250$ incident to the rendition of services, within the meaning of $\S 1.170 \mathrm{~A}-1$ (g). For substantiation of unreimbursed out-of-pocket expenses of $\$ 250$ or more, see $\S 1.170 \mathrm{~A}-13(\mathrm{f})(10)$.

(f) Charitable contributions made by partnership or $S$ corporation. If a partnership or an S corporation makes a charitable contribution, the partnership or S corporation is treated as the donor for purposes of section 170(f)(17) and paragraph (a) of this section.

(g) Transfers to certain trusts. The requirements of section $170(\mathrm{f})(17)$ and paragraphs (a)(1) and (3) of this section do not apply to a transfer of a cash, check, or other monetary gift to a trust described in section 170(f)(2)(B); a charitable remainder annuity trust, as described in section 664(d)(1) and the corresponding regulations; or a charitable remainder unitrust, as described in section 664(d)(2) or (d)(3) and the corresponding regulations. The requirements of section $170(f)(17)$ and paragraphs (a)(1) and (2) of this section do apply, however, to a transfer to a pooled income fund, as defined in section 642(c)(5). 
(h) Effective/applicability date. This section applies to contributions made after July 30, 2018. Taxpayers may rely on the rules of this section for contributions made in taxable years beginning after August 17, 2006.

- Par. 7. Section 1.170A-16 is added to read as follows:

\section{§1.170A-16 Substantiation and reporting requirements for noncash charitable contributions.}

(a) Substantiation of charitable contributions of less than \$250-(1) Individuals, partnerships, and certain corporations required to obtain receipt. Except as provided in paragraph (a)(2) of this section, no deduction is allowed under section 170(a) for a noncash charitable contribution of less than $\$ 250$ by an individual, partnership, S corporation, or $\mathrm{C}$ corporation that is a personal service corporation or closely held corporation unless the donor maintains for each contribution a receipt from the donee showing the following information:

(i) The name and address of the donee;

(ii) The date of the contribution;

(iii) A description of the property in sufficient detail under the circumstances (taking into account the value of the property) for a person who is not generally familiar with the type of property to ascertain that the described property is the contributed property; and

(iv) In the case of securities, the name of the issuer, the type of security, and whether the securities are publicly traded securities within the meaning of $\S 1.170 \mathrm{~A}-13(\mathrm{c})(7)(\mathrm{xi})$.

(2) Substitution of reliable written records-(i) In general. If it is impracticable to obtain a receipt (for example, where a donor deposits property at a donee's unattended drop site), the donor may satisfy the recordkeeping rules of this paragraph (a) by maintaining reliable written records, as described in paragraphs (a)(2)(ii) and (iii) of this section, for the contributed property.

(ii) Reliable written records. The reliability of written records is to be determined on the basis of all of the facts and circumstances of a particular case, including the proximity in time of the written record to the contribution.

(iii) Contents of reliable written records. Reliable written records must include-

(A) The information required by paragraph (a)(1) of this section;

(B) The fair market value of the property on the date the contribution was made;
(C) The method used in determining the fair market value; and

(D) In the case of a contribution of clothing or a household item as defined in $\S 1.170 \mathrm{~A}-18(\mathrm{c})$, the condition of the item.

(3) Additional substantiation rules may apply. For additional

substantiation rules, see paragraph (f) of this section.

(b) Substantiation of charitable contributions of $\$ 250$ or more but not more than $\$ 500$. No deduction is allowed under section 170(a) for a noncash charitable contribution of $\$ 250$ or more but not more than $\$ 500$ unless the donor substantiates the contribution with a contemporaneous written acknowledgment, as described in section 170(f)(8) and §1.170A-13(f).

(c) Substantiation of charitable contributions of more than $\$ 500$ but not more than \$5,000-(1) In general. No deduction is allowed under section 170(a) for a noncash charitable contribution of more than $\$ 500$ but not more than $\$ 5,000$ unless the donor substantiates the contribution with a contemporaneous written acknowledgment, as described in section 170(f)(8) and §1.170A-13(f), and meets the applicable requirements of this section.

(2) Individuals, partnerships, and certain corporations also required to file Form 8283 (Section A). No deduction is allowed under section 170(a) for a noncash charitable contribution of more than $\$ 500$ but not more than $\$ 5,000$ by an individual, partnership, $\mathrm{S}$ corporation, or $\mathrm{C}$ corporation that is a personal service corporation or closely held corporation unless the donor completes Form 8283 (Section A), "Noncash Charitable Contributions,", as provided in paragraph (c)(3) of this section, or a successor form, and files it with the return on which the deduction is claimed.

(3) Completion of Form 8283 (Section A). A completed Form 8283 (Section A) includes-

(i) The donor's name and taxpayer identification number (for example, a social security number or employer identification number);

(ii) The name and address of the donee;

(iii) The date of the contribution;

(iv) The following information about the contributed property:

(A) A description of the property in sufficient detail under the circumstances, taking into account the value of the property, for a person who is not generally familiar with the type of property to ascertain that the described property is the contributed property;
(B) In the case of real or tangible personal property, the condition of the property;

(C) In the case of securities, the name of the issuer, the type of security, and whether the securities are publicly traded securities within the meaning of $\S 1.170 \mathrm{~A}-13(\mathrm{c})(7)(\mathrm{xi})$;

(D) The fair market value of the property on the date the contribution was made and the method used in determining the fair market value;

(E) The manner of acquisition (for example, by purchase, gift, bequest, inheritance, or exchange), and the approximate date of acquisition of the property by the donor (except that in the case of a contribution of publicly traded securities as defined in $\S 1.170 \mathrm{~A}-$ 13(c)(7)(xi), a representation that the donor held the securities for more than one year is sufficient) or, if the property was created, produced, or manufactured by or for the donor, the approximate date the property was substantially completed;

(F) The cost or other basis, adjusted as provided by section 1016, of the property (except that the cost or basis is not required for contributions of publicly traded securities (as defined in $\S 1.170 \mathrm{~A}-13(\mathrm{c})(7)(\mathrm{xi}))$ that would have resulted in long-term capital gain if sold on the contribution date, unless the donor has elected to limit the deduction to basis under section 170(b)(1)(C)(iii));

$(\mathrm{G})$ In the case of tangible personal property, whether the donee has certified it for a use related to the purpose or function constituting the donee's basis for exemption under section 501, or in the case of a governmental unit, an exclusively public purpose; and

(v) Any other information required by Form 8283 (Section A) or the instructions to Form 8283 (Section A).

(4) Additional requirement for certain vehicle contributions. In the case of a contribution of a qualified vehicle described in section 170(f)(12)(E) for which an acknowledgment by the donee organization is required under section 170(f)(12)(D), the donor must attach a copy of the acknowledgment to the Form 8283 (Section A) for the return on which the deduction is claimed.

(5) Additional substantiation rules may apply. For additional substantiation rules, see paragraph (f) of this section.

(d) Substantiation of charitable contributions of more than $\$ 5,000-$ (1) In general. Except as provided in paragraph (d)(2) of this section, no deduction is allowed under section 170(a) for a noncash charitable contribution of more than $\$ 5,000$ unless the donor- 
(i) Substantiates the contribution with a contemporaneous written acknowledgment, as described in section $170(\mathrm{f})(8)$ and $\S 1.170 \mathrm{~A}-13(\mathrm{f})$;

(ii) Obtains a qualified appraisal, as defined in \$1.170A-17(a)(1), prepared by a qualified appraiser, as defined in $\S 1.170 \mathrm{~A}-17(\mathrm{~b})(1)$; and

(iii) Completes Form 8283 (Section B), as provided in paragraph $(\mathrm{d})(3)$ of this section, or a successor form, and files it with the return on which the deduction is claimed.

(2) Exception for certain noncash contributions. A qualified appraisal is not required, and a completed Form 8283 (Section A) containing the information required in paragraph (c)(3) of this section meets the requirements of paragraph (d)(1)(iii) of this section for contributions of-

(i) Publicly traded securities as defined in §1.170A-13(c)(7)(xi);

(ii) Property described in section 170(e)(1)(B)(iii) (certain intellectual property);

(iii) A qualified vehicle described in section 170(f)(12)(A)(ii) for which an acknowledgment under section 170(f)(12)(B)(iii) is provided; and

(iv) Property described in section 1221(a)(1) (inventory and property held by the donor primarily for sale to customers in the ordinary course of the donor's trade or business).

(3) Completed Form 8283 (Section B). A completed Form 8283 (Section B) includes-

(i) The donor's name and taxpayer identification number (for example, a social security number or employer identification number);

(ii) The donee's name, address, taxpayer identification number, signature, the date signed by the donee, and the date the donee received the property;

(iii) The appraiser's name, address, taxpayer identification number, appraiser declaration, as described in paragraph (d)(4) of this section, signature, and the date signed by the appraiser;

(iv) The following information about the contributed property:

(A) The fair market value on the valuation effective date, as defined in $\S 1.170 \mathrm{~A}-17(\mathrm{a})(5)(\mathrm{i})$.

(B) A description in sufficient detail under the circumstances, taking into account the value of the property, for a person who is not generally familiar with the type of property to ascertain that the described property is the contributed property.

(C) In the case of real property or tangible personal property, the condition of the property;

(v) The manner of acquisition (for example, by purchase, gift, bequest, inheritance, or exchange), and the approximate date of acquisition of the property by the donor, or, if the property was created, produced, or manufactured by or for the donor, the approximate date the property was substantially completed;

(vi) The cost or other basis of the property, adjusted as provided by section 1016;

(vii) A statement explaining whether the charitable contribution was made by means of a bargain sale and, if so, the amount of any consideration received for the contribution; and

(viii) Any other information required by Form 8283 (Section B) or the instructions to Form 8283 (Section B).

(4) Appraiser declaration. The appraiser declaration referred to in paragraph (d)(3)(iii) of this section must include the following statement: "I understand that my appraisal will be used in connection with a return or claim for refund. I also understand that, if there is a substantial or gross valuation misstatement of the value of the property claimed on the return or claim for refund that is based on my appraisal, I may be subject to a penalty under section $6695 \mathrm{~A}$ of the Internal Revenue Code, as well as other applicable penalties. I affirm that I have not been at any time in the three-year period ending on the date of the appraisal barred from presenting evidence or testimony before the Department of the Treasury or the Internal Revenue Service pursuant to 31 U.S.C. 330(c).'

(5) Donee signature-(i) Person authorized to sign. The person who signs Form 8283 (Section B) for the donee must be either an official authorized to sign the tax or information returns of the donee, or a person specifically authorized to sign Forms 8283 (Section B) by that official. In the case of a donee that is a governmental unit, the person who signs Form 8283 (Section B) for the donee must be an official of the governmental unit

(ii) Effect of donee signature. The signature of the donee on Form 8283 (Section B) does not represent concurrence in the appraised value of the contributed property. Rather, it represents acknowledgment of receipt of the property described in Form 8283 (Section B) on the date specified in Form 8283 (Section B) and that the donee understands the information reporting requirements imposed by section 6050L and $\S 1.6050 \mathrm{~L}-1$.

(iii) Certain information not required on Form 8283 (Section B) before donee signs. Before Form 8283 (Section B) is signed by the donee, Form 8283 (Section B) must be completed (as described in paragraph $(d)(3)$ of this section), except that it is not required to contain the following:

(A) The appraiser declaration or information about the qualified appraiser.

(B) The manner or date of acquisition.

(C) The cost or other basis of the property.

(D) The appraised fair market value of the contributed property.

(E) The amount claimed as a charitable contribution.

(6) Additional substantiation rules may apply. For additional substantiation rules, see paragraph (f) of this section.

(7) More than one appraiser. More than one appraiser may appraise the donated property. If more than one appraiser appraises the property, the donor does not have to use each appraiser's appraisal for purposes of substantiating the charitable contribution deduction under this paragraph (d). If the donor uses the appraisal of more than one appraiser, or if two or more appraisers contribute to a single appraisal, each appraiser shall comply with the requirements of this paragraph (d) and the requirements in $\S 1.170 \mathrm{~A}-17$, including signing the qualified appraisal and appraisal summary.

(e) Substantiation of noncash charitable contributions of more than $\$ 500,000-(1)$ In general. Except as provided in paragraph (e)(2) of this section, no deduction is allowed under section 170(a) for a noncash charitable contribution of more than $\$ 500,000$ unless the donor-

(i) Substantiates the contribution with a contemporaneous written acknowledgment, as described in section $170(\mathrm{f})(8)$ and $\S 1.170 \mathrm{~A}-13(\mathrm{f})$;

(ii) Obtains a qualified appraisal, as defined in $\S 1.170 \mathrm{~A}-17(\mathrm{a})(1)$, prepared by a qualified appraiser, as defined in $\S 1.170 \mathrm{~A}-17(\mathrm{~b})(1)$;

(iii) Completes, as described in paragraph (d)(3) of this section, Form 8283 (Section B) and files it with the return on which the deduction is claimed; and

(iv) Attaches the qualified appraisal of the property to the return on which the deduction is claimed.

(2) Exception for certain noncash contributions. For contributions of property described in paragraph $(d)(2)$ of this section, a qualified appraisal is not required, and a completed Form 8283 (Section A), containing the information required in paragraph (c)(3) of this section, meets the requirements of paragraph (e)(1)(iii) of this section.

(3) Additional substantiation rules may apply. For additional 
substantiation rules, see paragraph (f) of this section.

(f) Additional substantiation rules(1) Form 8283 (Section B) furnished by donor to donee. A donor who presents a Form 8283 (Section B) to a donee for signature must furnish to the donee a copy of the Form 8283 (Section B).

(2) Number of Forms 8283 (Section A or Section B)-(i) In general. For each item of contributed property for which a Form 8283 (Section A or Section B) is required under paragraphs (c), (d), or (e) of this section, a donor must attach a separate Form 8283 (Section A or Section B) to the return on which the deduction for the item is claimed.

(ii) Exception for similar items. The donor may attach a single Form 8283 (Section A or Section B) for all similar items of property, as defined in $\S 1.170 \mathrm{~A}-13$ (c)(7)(iii), contributed to the same donee during the donor's taxable year, if the donor includes on Form 8283 (Section A or Section B) the information required by paragraph (c)(3) or (d)(3) of this section for each item of property

(3) Substantiation requirements for carryovers of noncash contribution deductions. The rules in paragraphs (c), (d), and (e) of this section (regarding substantiation that must be submitted with a return) also apply to the return for any carryover year under section 170(d).

(4) Partners and $S$ corporation shareholders-(i) Form 8283 (Section A or Section B) must be provided to partners and $S$ corporation

shareholders. If the donor is a partnership or S corporation, the donor must provide a copy of the completed Form 8283 (Section A or Section B) to every partner or shareholder who receives an allocation of a charitable contribution deduction under section 170 for the property described in Form 8283 (Section A or Section B). Similarly, a recipient partner or shareholder that is a partnership or S corporation must provide a copy of the completed Form 8283 (Section A or Section B) to each of its partners or shareholders who receives an allocation of a charitable contribution deduction under section 170 for the property described in Form 8283 (Section A or Section B).

(ii) Partners and $S$ corporation shareholders must attach Form 8283 (Section A or Section B) to return. A partner of a partnership or shareholder of an $\mathrm{S}$ corporation who receives an allocation of a charitable contribution deduction under section 170 for property to which paragraph (c), (d), or (e) of this section applies must attach a copy of the partnership's or S corporation's completed Form 8283
(Section A or Section B) to the return on which the deduction is claimed.

(5) Determination of deduction amount for purposes of substantiation rules-(i) In general. In determining whether the amount of a donor's deduction exceeds the amounts set forth in section 170(f)(11)(B) (noncash contributions exceeding \$500), 170(f)(11)(C) (noncash contributions exceeding $\$ 5,000)$, or $170(f)(11)(D)$ (noncash contributions exceeding $\$ 500,000)$, the rules of paragraphs (f)(5)(ii) and (iii) of this section apply.

(ii) Similar items of property must be aggregated. Under section 170(f)(11)(F), the donor must aggregate the amount claimed as a deduction for all similar items of property, as defined in $\S 1.170 \mathrm{~A}-13$ (c)(7)(iii), contributed during the taxable year. For rules regarding the number of qualified appraisals and Forms 8283 (Section A or Section B) required if similar items of property are contributed, see $\S 1.170 \mathrm{~A}-$ 13(c)(3)(iv)(A) and (4)(iv)(B).

(iii) For contributions of certain inventory and scientific property, excess of amount claimed over cost of goods sold taken into account-(A) In general. In determining the amount of a donor's contribution of property to which section 170(e)(3) (relating to contributions of inventory and other property) or (e)(4) (relating to contributions of scientific property used for research) applies, the donor must take into account only the excess of the amount claimed as a deduction over the amount that would have been treated as the cost of goods sold if the donor had sold the contributed property to the donee.

(B) Example. The following example illustrates the rule of this paragraph (f)(5)(iii):

Example. $X$ Corporation makes a contribution of inventory described in section 1221(a)(2). The contribution, described in section 170(e)(3), is for the care of the needy. The cost of the property to $X$ Corporation is $\$ 5,000$ and the fair market value of the property at the time of the contribution is $\$ 11,000$. Pursuant to section 170(e)(3)(B), $X$ Corporation claims a charitable contribution deduction of $\$ 8,000$ $(\$ 5,000+1 / 2 \times(\$ 11,000-5,000)=\$ 8,000)$. The amount taken into account for purposes of determining the $\$ 5,000$ threshold of paragraph (d) of this section is $\$ 3,000$ $(\$ 8,000-\$ 5,000)$.

(g) Effective/applicability date. This section applies to contributions made after July 30, 2018. Taxpayers may rely on the rules of this section for contributions made after June 3, 2004, or appraisals prepared for returns or submissions filed after August 17, 2006.
Par. 8. Section 1.170A-17 is added to read as follows:

\section{\$1.170A-17 Qualified appraisal and qualified appraiser.}

(a) Qualified appraisal-(1)

Definition. For purposes of section 170(f)(11) and §1.170A-16(d)(1)(ii) and (e)(1)(ii), the term qualified appraisal means an appraisal document that is prepared by a qualified appraiser (as defined in paragraph (b)(1) of this section) in accordance with generally accepted appraisal standards (as defined in paragraph (a)(2) of this section) and otherwise complies with the requirements of this paragraph (a).

(2) Generally accepted appraisal standards defined. For purposes of paragraph (a)(1) of this section, generally accepted appraisal standards means the substance and principles of the Uniform Standards of Professional Appraisal Practice, as developed by the Appraisal Standards Board of the Appraisal Foundation.

(3) Contents of qualified appraisal. A qualified appraisal must include-

(i) The following information about the contributed property:

(A) A description in sufficient detail under the circumstances, taking into account the value of the property, for a person who is not generally familiar with the type of property to ascertain that the appraised property is the contributed property.

(B) In the case of real property or tangible personal property, the condition of the property.

(C) The valuation effective date, as defined in paragraph (a)(5)(i) of this section.

(D) The fair market value, within the meaning of $\S 1.170 \mathrm{~A}-1$ (c)(2), of the contributed property on the valuation effective date;

(ii) The terms of any agreement or understanding by or on behalf of the donor and donee that relates to the use, sale, or other disposition of the contributed property, including, for example, the terms of any agreement or understanding that-

(A) Restricts temporarily or permanently a donee's right to use or dispose of the contributed property;

(B) Reserves to, or confers upon, anyone, other than a donee or an organization participating with a donee in cooperative fundraising, any right to the income from the contributed property or to the possession of the property, including the right to vote contributed securities, to acquire the property by purchase or otherwise, or to designate the person having income, possession, or right to acquire; or

(C) Earmarks contributed property for a particular use; 
(iii) The date, or expected date, of the contribution to the donee;

(iv) The following information about the appraiser:

(A) Name, address, and taxpayer identification number.

(B) Qualifications to value the type of property being valued, including the appraiser's education and experience.

(C) If the appraiser is acting in his or her capacity as a partner in a partnership, an employee of any person, whether an individual, corporation, or partnership, or an independent contractor engaged by a person other than the donor, the name, address, and taxpayer identification number of the partnership or the person who employs or engages the qualified appraiser;

(v) The signature of the appraiser and the date signed by the appraiser (appraisal report date);

(vi) The following declaration by the appraiser: "I understand that my appraisal will be used in connection with a return or claim for refund. I also understand that, if there is a substantial or gross valuation misstatement of the value of the property claimed on the return or claim for refund that is based on my appraisal, I may be subject to a penalty under section 6695A of the Internal Revenue Code, as well as other applicable penalties. I affirm that I have not been at any time in the three-year period ending on the date of the appraisal barred from presenting evidence or testimony before the Department of the Treasury or the Internal Revenue Service pursuant to 31 U.S.C. 330(c)";

(vii) A statement that the appraisal was prepared for income tax purposes;

(viii) The method of valuation used to determine the fair market value, such as the income approach, the market-data approach, or the replacement-cost-lessdepreciation approach; and

(ix) The specific basis for the valuation, such as specific comparable sales transactions or statistical sampling, including a justification for using sampling and an explanation of the sampling procedure employed.

(4) Timely appraisal report. A qualified appraisal must be signed and dated by the qualified appraiser no earlier than 60 days before the date of the contribution and no later than-

(i) The due date, including extensions, of the return on which the deduction for the contribution is first claimed;

(ii) In the case of a donor that is a partnership or S corporation, the due date, including extensions, of the return on which the deduction for the contribution is first reported; or (iii) In the case of a deduction first claimed on an amended return, the date on which the amended return is filed.

(5) Valuation effective date-(i) Definition. The valuation effective date is the date to which the value opinion applies.

(ii) Timely valuation effective date. For an appraisal report dated before the date of the contribution, as described in $\S 1.170 \mathrm{~A}-1(\mathrm{~b})$, the valuation effective date must be no earlier than 60 days before the date of the contribution and no later than the date of the contribution. For an appraisal report dated on or after the date of the contribution, the valuation effective date must be the date of the contribution.

(6) Exclusion for donor knowledge of falsity. An appraisal is not a qualified appraisal for a particular contribution, even if the requirements of this paragraph (a) are met, if the donor either failed to disclose or misrepresented facts, and a reasonable person would expect that this failure or misrepresentation would cause the appraiser to misstate the value of the contributed property.

(7) Number of appraisals required. A donor must obtain a separate qualified appraisal for each item of property for which an appraisal is required under section 170(f)(11)(C) and (D) and paragraph (d) or (e) of $\S 1.170 \mathrm{~A}-16$ and that is not included in a group of similar items of property, as defined in $\S 1.170 \mathrm{~A}-13(\mathrm{c})(7)(\mathrm{iii})$. For rules regarding the number of appraisals required if similar items of property are contributed, see section $170(f)(11)(F)$ and $\$ 1.170 \mathrm{~A}-13(\mathrm{c})(3)(\mathrm{iv})(\mathrm{A})$.

(8) Time of receipt of qualified appraisal. The qualified appraisal must be received by the donor before the due date, including extensions, of the return on which a deduction is first claimed, or reported in the case of a donor that is a partnership or S corporation, under section 170 with respect to the donated property, or, in the case of a deduction first claimed, or reported, on an amended return, the date on which the return is filed.

(9) Prohibited appraisal fees. The fee for a qualified appraisal cannot be based to any extent on the appraised value of the property. For example, a fee for an appraisal will be treated as based on the appraised value of the property if any part of the fee depends on the amount of the appraised value that is allowed by the Internal Revenue Service after an examination.

(10) Retention of qualified appraisal. The donor must retain the qualified appraisal for so long as it may be relevant in the administration of any internal revenue law.

(11) Effect of appraisal disregarded pursuant to 31 U.S.C. $330(\mathrm{c})$. If an appraiser has been prohibited from practicing before the Internal Revenue Service by the Secretary under 31 U.S.C. 330(c) at any time during the three-year period ending on the date the appraisal is signed by the appraiser, any appraisal prepared by the appraiser will be disregarded as to value, but could constitute a qualified appraisal if the requirements of this section are otherwise satisfied, and the donor had no knowledge that the signature, date, or declaration was false when the appraisal and Form 8283 (Section B) were signed by the appraiser.

(12) Partial interest. If the contributed property is a partial interest, the appraisal must be of the partial interest.

(b) Qualified appraiser-(1)

Definition. For purposes of section 170(f)(11) and §1.170A-16(d)(1)(ii) and (e)(1)(ii), the term qualified appraiser means an individual with verifiable education and experience in valuing the type of property for which the appraisal is performed, as described in paragraphs (b)(2) through (4) of this section.

(2) Education and experience in valuing the type of property-(i) In general. An individual is treated as having education and experience in valuing the type of property within the meaning of paragraph (b)(1) of this section if, as of the date the individual signs the appraisal, the individual has-

(A) Successfully completed (for example, received a passing grade on a final examination) professional or college-level coursework, as described in paragraph (b)(2)(ii) of this section, in valuing the type of property, as described in paragraph (b)(3) of this section, and has two or more years of experience in valuing the type of property, as described in paragraph (b)(3) of this section; or

(B) Earned a recognized appraiser designation, as described in paragraph (b)(2)(iii) of this section, for the type of property, as described in paragraph (b)(3) of this section.

(ii) Coursework must be obtained from an educational organization, generally recognized professional trade or appraiser organization, or employer educational program. For purposes of paragraph (b)(2)(i)(A) of this section, the coursework must be obtained from-

(A) A professional or college-level educational organization described in section $170(\mathrm{~b})(1)(\mathrm{A})(\mathrm{ii})$;

(B) A generally recognized professional trade or appraiser organization that regularly offers 
educational programs in valuing the type of property; or

(C) An employer as part of an employee apprenticeship or educational program substantially similar to the educational programs described in paragraphs (b)(2)(ii)(A) and (B) of this section.

(iii) Recognized appraiser designation defined. A recognized appraiser designation means a designation awarded by a generally recognized professional appraiser organization on the basis of demonstrated competency.

(3) Type of property defined-(i) In general. The type of property means the category of property customary in the appraisal field for an appraiser to value.

(ii) Examples. The following examples illustrate the rule of paragraphs (b)(2)(i) and (b)(3)(i) of this section

Example (1). Coursework in valuing type of property. There are very few professionallevel courses offered in widget appraising, and it is customary in the appraisal field for personal property appraisers to appraise widgets. Appraiser $A$ has successfully completed professional-level coursework in valuing personal property generally but has completed no coursework in valuing widgets. The coursework completed by Appraiser $A$ is for the type of property under paragraphs (b)(2)(i) and (b)(3)(i) of this section.

Example (2). Experience in valuing type of property. It is customary for professional antique appraisers to appraise antique widgets. Appraiser $B$ has 2 years of experience in valuing antiques generally and is asked to appraise an antique widget. Appraiser $B$ has obtained experience in valuing the type of property under paragraphs (b)(2)(i) and (b)(3)(i) of this section.

Example (3). No experience in valuing type of property. It is not customary for professional antique appraisers to appraise new widgets. Appraiser $C$ has experience in appraising antiques generally but no experience in appraising new widgets. Appraiser $C$ is asked to appraise a new widget. Appraiser $C$ does not have experience in valuing the type of property under paragraphs (b)(2)(i) and (b)(3)(i) of this section.

(4) Verifiable. For purposes of paragraph (b)(1) of this section, education and experience in valuing the type of property are verifiable if the appraiser specifies in the appraisal the appraiser's education and experience in valuing the type of property, as described in paragraphs (b)(2) and (3) of this section, and the appraiser makes a declaration in the appraisal that,

because of the appraiser's education and experience, the appraiser is qualified to make appraisals of the type of property being valued.

(5) Individuals who are not qualified appraisers. The following individuals are not qualified appraisers for the appraised property:

(i) An individual who receives a fee prohibited by paragraph (a)(9) of this section for the appraisal of the appraised property.

(ii) The donor of the property.

(iii) A party to the transaction in which the donor acquired the property (for example, the individual who sold, exchanged, or gave the property to the donor, or any individual who acted as an agent for the transferor or for the donor for the sale, exchange, or gift), unless the property is contributed within 2 months of the date of acquisition and its appraised value does not exceed its acquisition price.

(iv) The donee of the property.

(v) Any individual who is either-

(A) Related, within the meaning of section 267(b), to, or an employee of, an individual described in paragraph (b)(5)(ii), (iii), or (iv) of this section;

(B) Married to an individual described in paragraph (b)(5)(v)(A) of this section; or

(C) An independent contractor who is regularly used as an appraiser by any of the individuals described in paragraph (b)(5)(ii), (iii), or (iv) of this section, and who does not perform a majority of his or her appraisals for others during the taxable year.

(vi) An individual who is prohibited from practicing before the Internal Revenue Service by the Secretary under 31 U.S.C. 330(c) at any time during the three-year period ending on the date the appraisal is signed by the individual.

(c) Effective/applicability date. This section applies to contributions made on or after January 1, 2019. Taxpayers may rely on the rules of this section for appraisals prepared for returns or submissions filed after August 17, 2006.

- Par. 9. Section 1.170A-18 is added to read as follows:

\section{§1.170A-18 Contributions of clothing and household items.}

(a) In general. Except as provided in paragraph (b) of this section, no deduction is allowed under section 170(a) for a contribution of clothing or a household item (as described in paragraph (c) of this section) unless-

(1) The item is in good used condition or better at the time of the contribution; and

(2) The donor meets the substantiation requirements of $\S 1.170 \mathrm{~A}-16$.

(b) Certain contributions of clothing or household items with claimed value of more than \$500. The rule described in paragraph (a)(1) of this section does not apply to a contribution of a single item of clothing or a household item for which a deduction of more than $\$ 500$ is claimed, if the donor submits with the return on which the deduction is claimed a qualified appraisal, as defined in $\S 1.170 \mathrm{~A}-17(\mathrm{a})(1)$, of the property prepared by a qualified appraiser, as defined in $\$ 1.170 \mathrm{~A}-17(\mathrm{~b})(1)$, and a completed Form 8283 (Section B),

"Noncash Charitable Contributions," as described in §1.170A-16(d)(3).

(c) Definition of household items. For purposes of section 170(f)(16) and this section, the term household items includes furniture, furnishings, electronics, appliances, linens, and other similar items. Food, paintings, antiques, and other objects of art, jewelry, gems, and collections are not household items.

(d) Effective/applicability date. This section applies to contributions made after July 30, 2018. Taxpayers may rely on the rules of this section for contributions made after August 17, 2006.

- Par. 10. § 1.664-1 is amended by revising paragraph (a)(7)(i)(b) and adding a sentence to the end of paragraph (f)(1) to read as follows:

§1.664-1. Charitable remainder trusts.

(a) ***

(7) ***

(i) ***

(b) Determined by a current qualified appraisal from a qualified appraiser, as those terms are defined in-

(1) Section 1.170A-13(c)(3) and 1.170A-13(c)(5), respectively, for appraisals prepared for returns or submissions filed on or before August 17, 2006;

(2) Section 3 of Notice 2006-96, 2006-2 CB 902, for appraisals prepared for returns or submissions filed after August 17, 2006, if the donations are made before January 1, 2019; or

(3) Section 1.170A-17(a) and 1.170A17(b), respectively, for appraisals prepared for returns or submissions for donations made on or after January 1 , 2019.

$$
\text { * } * * * * *
$$
$\S 1.664-1(\mathrm{a})(7)(\mathrm{i})(\mathrm{b})$ apply as provided in that paragraph.

- Par. 10. § 1.6050L-1 is amended by:

- 1. Revising the first two sentences of paragraph (a)(2)(i).

2. Revising paragraphs (c)(4)(i)

introductory text and (d)(2).

- 3. Revising the first sentences of paragraphs (e) and (f)(2)(ii).

- 4. Adding paragraph (h).

The revisions and addition read as follows: 
\$1.6050L-1. Information return by donees relating to certain dispositions of donated property.

(a) ***

(2) ***

(i) In general. Paragraph (a)(1) of this section shall not apply with respect to an item of charitable deduction property disposed of by sale if the Form 8283 appraisal summary (as described in $\S 1.170 \mathrm{~A}-13(\mathrm{c})(4)$ for contributions made on or before July 30, 2018 and $\S 1.170 \mathrm{~A}-16(\mathrm{~d})(3)$ for contributions made after July 30, 2018), or a successor form, signed by the donee with respect to the item contains, at the time of the donee's signature, a statement signed by the donor that the appraised value of the item does not exceed $\$ 500$. In the case of a Form 8283 appraisal summary that describes more than one item, this exception shall apply only with respect to an item clearly identified as having an appraised value of $\$ 500$ or

less. ***

(c) ***

(4) ***

(i) Shall provide its name, address, and employer identification number and a copy of the Form 8283 appraisal summary (as described in $\S 1.170 \mathrm{~A}-$ 13(c)(4) for contributions made on or before July 30, 2018 and $\S 1.170 \mathrm{~A}-$ 16(d)(3) for contributions made after July 30, 2018) relating to the transferred property to the successor donee on or before the 15th day after the latest of-

(d) ***

(2) Retention of Form 8283 appraisal summary. Every donee shall retain the Form 8283 appraisal summary (as described in $\S 1.170 \mathrm{~A}-13$ (c)(4) for contributions made on or before July 30 , 2018 and $\S 1.170 \mathrm{~A}-16(\mathrm{~d})(3)$ for contributions made after July 30, 2018) in the donee's records for so long as it may be relevant in the administration of any internal revenue law.

(e) Charitable deduction property. For purposes of this section, the term charitable deduction property means any property (other than money and publicly traded securities to which $\S 1.170 \mathrm{~A}-13(\mathrm{c})(7)(\mathrm{xi})(\mathrm{B})$ does not apply) contributed after December 31, 1984, with respect to which the donee signs (or is presented with for signature in cases described in $\S 1.170 \mathrm{~A}-$

13(c)(4)(iv)(C)(2)) a Form 8283 appraisal summary (as described in $\S 1.170 \mathrm{~A}-$ 13(c)(4) for contributions made on or before July 30, 2018 and $\S 1.170 \mathrm{~A}-$ 16(d)(3) for contributions made after July 30,2018$). * * *$

\section{(f) *** \\ (2) *** \\ DEPARTMENT OF HOMELAND SECURITY}

(ii) Exception. Notwithstanding

paragraph (f)(2)(i) of this section, in the case of a donee who, on the date of receipt of the transferred property, had no reason to believe that the substantiation requirements of $\S 1.170 \mathrm{~A}-13(\mathrm{c})$ or $\S 1.170 \mathrm{~A}-16(\mathrm{~d})$ apply with respect to the property, the donee information return is not required to be filed until the 60th day after the date on which such donee has reason to believe that the substantiation requirements of $\S 1.170 \mathrm{~A}-13(\mathrm{c})$ or $\S 1.170 \mathrm{~A}-16(\mathrm{~d})$ apply with respect to the property. * * *

(h) Effective/applicability dates. The first two sentences of paragraph (a)(2)(i), paragraphs (c)(4)(i) and (d)(2), and the first sentences of paragraphs (e) and (f)(2)(ii) apply to contributions made after July 30, 2018.

\section{PART 602-OMB CONTROL NUMBERS UNDER THE PAPERWORK REDUCTION ACT}

Par. 11. The authority citation for part 602 continues to read as follows:

Authority: 26 U.S.C. 7805.

- Par. 12. In § 602.101, paragraph (b) is amended by adding in numerical order entries for 1.170A-15 through 1.170A18 to read as follows:

\section{\$602.101 OMB Control numbers.}

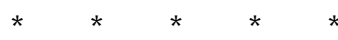

(b) ***

\begin{tabular}{|c|c|}
\hline $\begin{array}{l}\text { CFR part or section where } \\
\text { identified and described }\end{array}$ & $\begin{array}{l}\text { Current OMB } \\
\text { control No. }\end{array}$ \\
\hline $1.170 \mathrm{~A}-15$ & $1545-1953$ \\
\hline $1.170 \mathrm{~A}-16$ & $1545-1953$ \\
\hline $1.170 \mathrm{~A}-17 \ldots$ & $1545-1953$ \\
\hline $1.170 \mathrm{~A}-18$ & $1545-1953$ \\
\hline
\end{tabular}

Kirsten Wielobob,

Deputy Commissioner for Services and Enforcement.

Approved: April 23, 2018.

David J. Kautter,

Assistant Secretary of the Treasury (Tax Policy).

[FR Doc. 2018-15734 Filed 7-27-18; 8:45 am] BILLING CODE 4830-01-P
Coast Guard

\section{CFR Part 117}

[Docket No. USCG-2018-0730]

\section{Drawbridge Operation Regulation; Gulf Intracoastal Waterway, South Pasadena, FL}

AGENCY: Coast Guard, DHS.

ACTION: Notice of deviation from drawbridge regulation.

SUMmARY: The Coast Guard has issued a temporary deviation from the operating schedule that governs the Corey Causeway (SR693) Bridge across the Gulf Intracoastal Waterway (GICW), mile 117.7, South Pasadena, FL. The deviation is necessary to accommodate repairs to the Bridge. This deviation allows the bridge open at requested times a single leaf and with a 6 hour notice for double leaf openings.

DATES: This deviation is effective from 7 a.m. on August 1, 2018 to 7 a.m. on February 28, 2019.

ADDRESSES: The docket for this deviation, USCG-2018-0730 is available at http://www.regulations.gov. Type the docket number in the "SEARCH" box and click "SEARCH". Click on Open Docket Folder on the line associated with this deviation.

FOR FURTHER INFORMATION CONTACT: If you have questions on this temporary deviation, call or email MST1 Deborah A. Schneller, U.S. Coast Guard Sector Saint Petersburg, Waterways Management Division, telephone (813) 228-2194 x 8133, email

Deborah.A.Schneller@uscg.mil. SUPPLEMENTARY INFORMATION: Florida Department of Transportation (FDOT) via Quinn Construction Inc, has requested a temporary deviation from the operation that govern the Corey Causeway Bridge across the Gulf Intracoastal Waterway, mile 117.7. This deviation is necessary to facilitate mechanical and electrical repairs, painting, roadway and sidewalk grating replacement which includes concrete removal, spall repair and tender house replacement. The bridge is a double-leaf bascule bridge and has a vertical clearance in the closed to navigation position of 23 feet at mean high water.

The current operating schedule is set out in 33 CFR 117.287(f). Under this temporary deviation, the bridge will operate per the listed schedule but single leaf only and with a 6 hour notice for double leaf openings. This section of the Gulf Intracoastal Waterway is 


\section{IRS FORM 8283 SUPPLEMENTAL STATEMENT DONATION OF CONSERVATION EASEMENT ${ }^{1}$}

On December 8, 2017, Cartwright Holdings, LLC, a Nevada limited liability company, the owner of record (the "LLC," or the "donor"), with a mailing address , donated a conservation easement (the "Easement") under Section 170(h) of the Internal Revenue Code of 1986, as amended, and the regulations thereunder (the "Code"), on approximately 38 acres (the "Property") out of a larger parcel of 45+/- contiguous acres owned by the LLC in East Standwich, Open Space County, [State]. A resolution dated December 1, 2017, and signed by all of the members of the LLC, authorized the LLC to convey a conservation easement to the Town of East Standwich, as a gift and for no consideration, on 38 acres of the property owned by the LLC in East Standwich.

Pursuant to Chief Counsel Advice No. 201334039 (release date August 23, 2013), and Treas. Reg. Section 1.170A-14(h), the appraiser has valued all of the donor's contiguous property before the Easement and all of the donor's contiguous property after the Easement. ${ }^{2}$ Accordingly, for purposes of the qualified appraisal report filed herewith, the entire $45+/$ - acre contiguous parcel owned by the donor is valued both before and after the conveyance of the Easement.

The donation of the Easement was made to the Town of East Standwich, a [State] municipal corporation ("Grantee"), a government agency having an address at 445 Blooming Ave., East Standwich, [State] [zip] ("Grantee"). Grantee has the commitment and the resources to enforce the terms of the Easement and is a "qualified organization" under Section 170(h) of the Code.

The Easement was recorded on December 8, 2017, at Book , Page

in the Recorder's Office in Open Space County, [State]. Accordingly, as the appraiser's

\footnotetext{
${ }^{1}$ This document is not and does not offer legal advice. Use at your own risk. There is no guarantee whatsoever that if you use this language, or something close to it, you will not be audited on this issue, and there is no guarantee that if you are audited on this issue your deduction will not be denied. In that regard, the Internal Revenue Service has not recommended, ruled on, endorsed, or otherwise, formally or informally, liked this language. Copyright 2019 by Stephen J. Small, Esq., all rights reserved. ${ }^{2}$ Determining exactly what to appraise requires (i) an understanding of the specific conservation easement valuation rules (including but not limited to the definition of "contiguous" in your state), and (ii) knowledge of what if any property that might be relevant to the appraisal is owned by the donor, members of the donor's family, and "related persons," as defined by the Treasury Regulations.
} 
certification in the qualified appraisal was signed on April 16, 2018, ${ }^{3}$ the effective date for purposes of determining the value of the Easement under Section 170(h) of the Code is December 8, 2017.

The Easement allows public access to and across a designated portion of the Property, referred to as the "Trail" in the Easement, for passive pedestrian outdoor recreation. No motorized vehicles are permitted on the Trail. In addition, the Trail will provide for enhanced public access to and the use of the greater trail network that extends through East Standwich's Historic District and ridgelines. On November 29, 2017, the Town of East Standwich, the Grantee, in a public session, unanimously approved the acquisition of this Easement, citing the importance of maintaining the Property in a scenic, natural, and permitting access along the Trail.

As discussed above and below, by retaining the Property in perpetuity in its current open and undeveloped state, the Easement donation allows for public outdoor recreation, yields a significant public benefit, protects important scenic open space, important habitat and other natural and scientific resources, and is pursuant to clearly delineated government policy.

\section{THE PROPERTY AND ITS CONSERVATION VALUES}

The Property has the following conservation values, which are covered in greater detail in the Easement and in the Baseline Documentation Report (as hereinafter defined): (i) protection of land areas for public outdoor recreation and education; (ii) protection of significant habitat; (iii) preservation of open space for the scenic enjoyment of the general public, which yields a significant public benefit; and (iv) preservation of open space pursuant to clearly delineated governmental policy, including historic preservation value, which yields a significant public benefit.

This Easement protects land areas for public outdoor recreation and education and therefore this Easement meets the requirements of Section 170(h)(4)(A)(i) of the Code:

As previously noted, the Easement allows public access along a Trail into and across the Property. In addition, the Trail will provide for enhanced public access to and the use of the greater trail network that extends through East Standwich's Historic District and ridgelines.

Protection of the Property will preserve significant relatively natural habitat and therefore this Easement meets the requirements of Section 170(h)(4)(A)(ii) of the Code:

The Property has native vegetation, including forestland comprised of Quaking Aspen Groves, Bigtooth Maple and Gambel Oak. The Property is habitat for a wildlife including large game, ground mammals including marmot, squirrel, ermine and birds (ruffed grouse). Mule Deer, Elk, and

\footnotetext{
${ }^{3}$ If more than one appraiser signed the appraisal and appraisal certificate, and accordingly the Form 8283 , this should be adjusted.
} 
Moose frequent the Property year-round. The Property is adjacent to protected open space and open public lands that extend to larger mountainous areas that provide quality habitat for wildlife, and protection of the Property will create a larger contiguous bloc of habitat. Preservation of the Property will contribute to the ecological viability of native plants and wildlife.

Protection of the Property is for the scenic enjoyment of the general public and will yield a significant public benefit, and therefore this Easement meets the requirements of Section 170(h)(4)(A)(iii)(I) of the Code:

The hillside on the Property continues a natural scenic barrier between the East Standwich Historic District and the Hummer Hill development, contributing to the quiet semi-rural town feel. The Property's protected hillside can be viewed from the Hummer Hill neighborhood, including Cartwright Ave, and Antelope Valley Drive; the Property can be viewed from public trails located on the adjacent Management; easement and a parcel owned by the Bureau of Land

the Property is within the viewshed of the East Standwich Historic District, a nationally recognized Historic District. The Property is within a neighborhood with multiple properties and structures listed on the National Register of Historic Places. Preserving the Property contributes to the feel and character of the historic neighborhood, and prevents development that is incongruous to the historic aspect;

the Property is visible from public access trails on adjacent land owned by the Town of East Standwich and permanently protected by a conservation easement, and said public access trails may extend to the Property in the future. The Property is part of a natural and scenic open space buffer between the East Standwich Historic District and the Antelope Valley development.

Protection of the Property is pursuant to clearly delineated federal, state, and local governmental conservation policies, and will yield a significant public benefit, and therefore this Easement meets the requirements of Section 170(h)(4)(a)(iii)(II) of the Code:

as previously noted, on November 29, 2017, the Town Board of East Standwich unanimously approved the acquisition of this Easement, and cited the importance of maintaining the Property in a scenic, natural, and pedestrian accessible condition, and commending Grantor for making this commitment;

as noted above, the Property is within the viewshed of the East Standwich, Historic District. The Property is adjacent to a zoned Historic District, and is within a neighborhood with multiple properties and structures listed on the National Register of Historic Places. Preserving the Property 
contributes to the feel and character of the historic neighborhood, and prevents development that is incongruous to the historic aspect; and

the public benefits from preserving open space in the bordering areas of historic main street by creating a more substantial buffer zone between new residential development and the classic character of the Historic District. In addition, the Property is located on a narrow road with large vehicles and increased traffic that has resulted in recent years from the construction of new homes on Hummer Hill. Preventing residential development will mitigate future traffic impacts in an already heavily-travelled area.

\section{THE CONSERVATION EASEMENT}

The Easement is very restrictive. It prohibits the division of the Property and prohibits residential construction, commercial activities, and industrial activities on the Property, thereby extinguishing almost all of the Property's development rights potentially allowable under applicable zoning regulations. The Easement prohibits any activity on the Property that would interfere with the perpetual protection of the Property's conservation values, as those are defined in the Easement and set forth above. The Easement allows public access to and across a designated portion of the Property, referred to as the "Trail" in the Easement, for passive pedestrian outdoor recreation, and prohibits the use of motorized vehicles on the Trail. In addition, the Trail will connect to and therefore provide for enhanced public access to and use of the greater trail network that extends through East Standwich's Historic District and surrounding property.

\section{VALUATION AND RELATED MATTERS}

Applying the sales comparison approach, the appraiser concluded that the fair market value of the Easement is determined as follows:

a. Fair market value of the entire contiguous property owned by the donor before donation of the Easement: $\$ 3,800,000$

b. Fair market value of the entire contiguous property owned by the donor after donation of the Easement: $\$ 1,700,000$

c. Fair market value of the Easement: $\$ 2,100,000$

The donor's basis in the entire contiguous property is $\$ 3,374,779$. A copy of the qualified appraisal report dated April 16, 2018, that substantiates these values is filed with this Form 8283. A copy of the recorded Easement is included in the qualified appraisal report. As noted above, the Easement was recorded on December 8, 2017 (the effective date of the Easement), at Book , Page: , in the Recorder's Office in Open Space County, [State].

As described in greater detail in the attached qualified appraisal, neither the donor nor related family members or related persons (as defined by the Treasury Regulations) 
own any other property the value of which is increased by the Easement, so no further adjustment is required to the conclusion of value. The donation of the Easement was not made to obtain a permit or other approval from a local or other governing authority, nor was the donation required by any contractual obligation.

The condition of the Property at the time of the donation was documented and established through extensive documentation in a contemporaneous Baseline Documentation Report, dated November 25, 2017, and acknowledged by the parties to the donation in accordance with Treas. Reg. Section 1.170A-14(g)(5). A copy of the Baseline Documentation Report is filed herewith. A copy of the contemporaneous written acknowledgement of the gift of the Easement required by Section 170(f)(8) of the Code is also filed herewith.

\section{Attachments}

Copies of the following are filed with this Form 8283:

Qualified appraisal report dated April 16, 2018, with effective date December 8, 2017 (date of recording of the Easement) (appraisal report includes copy of recorded Easement)

Code Section 170(f)(8) donation acknowledgement letter from Grantee East Standwich Municipal Corporation.

Contemporaneous Baseline Documentation Report dated November 25, 2017 


\title{
$\underline{\text { Appendix G }}$
}

\section{Limited Amendment Provision}

$* * * * * * *$ This is not legal advice. There is no guarantee whatsoever that if you use this language, or something close to it, you will not be audited on this issue, and there is no guarantee that if you are audited on this issue your deduction will not be denied. In that regard, the Internal Revenue Service has not recommended, ruled on, endorsed, or otherwise, formally or informally, liked this language. Given the still unsettled law on the issue of amending conservation easements, some practitioners will prefer to use different language or to draft conservation easements with no amendment provision whatsoever. Use or modify at your own risk. And I really mean it.

\section{Law Office of Stephen J. Small, Esq., P.C.}

\author{
$4 / 19 / 19 \mathrm{draft}$
}

\subsection{Limitations on Amendment}

(a) Background; Acting in Good Faith Grantor and Grantee have been informed that the Internal Revenue Service has been concerned about the possibility of the parties thereto amending conservation easements in the future in a manner that fails to protect the conservation values of the subject property in perpetuity. Accordingly, Grantor and Grantee have agreed to include a suitably restrictive amendment clause in this Easement, to address IRS concerns.

(b) In General Grantor and Grantee recognize that natural conditions, landscapes, and technologies change over time (including best practices of open space stewardship techniques), and, in an abundance of caution, have determined, in good faith, to articulate herein the limited parameters of any permissible amendment hereto. The intent of Grantor and Grantee is that (except in a case involving solely the correction of a drafting mistake, or mapping error, or in a situation involving solely adding additional property to the existing encumbered property or otherwise eliminating or further restricting previously reserved rights) any such amendment would 
be executed only in rare instances and unusual circumstances not envisioned by either party at the time of this grant, consistent with and true to the perpetual protection of the Conservation Values, and consistent with the goals and provisions of [citation to state statute] and the goals and provisions of Section 170(h) of the Code. Further, it may be necessary at some point to amend this Easement in response to changes over time specifically to ensure the perpetual protection of the Conservation Values. This Section 5.03 is accordingly carefully limited so as to ensure that no amendment shall in any way impair the perpetual protection of the Conservation Values. Nothing in this Section 5.03 shall require Grantor or Grantee to agree to any amendment or to consult or negotiate regarding any amendment.

(c) Limitations on Amendment This Easement shall be amended only upon the written agreement of Grantee and Grantor, at Grantee's sole and absolute discretion, but only if such amendment: (i) does not constitute private inurement or give rise to an impermissible private benefit under Section 501(c)(3) and other applicable provisions of the Code or the law of [state], based on an appraisal of the economic impact of the proposed amendment by an appraiser selected by Grantee; (ii) has a neutral or positive effect on the Conservation Values*, based on an evaluation of the effect of the proposed amendment on the Conservation Values by an independent qualified person selected by Grantee; (iii) is consistent with the purpose of this Easement and the perpetual protection of the Conservation Values; (iv) does not affect the perpetual nature of this Easement; and (v) complies with [state statute] and Section 170(h) of the Code. Further, no amendment shall be permitted that (vi) causes the provisions of this Section 5.03 to be less restrictive, (vii) does not comply with the provisions of this Section 5.03, (viii) would involve the removal of any of the Property from the Easement, or (ix) would alter or remove the restrictions on assignment of this Easement under the provisions of Section , or the provisions on extinguishment, percentage 
interests, or condemnation under Section . In the case of any amendment, all of the requirements and restrictions in this Section 5.03 must be satisfied.

(d) Updated Baseline Documentation Report In the event Grantor and Grantee agree to an amendment pursuant to the provisions of this Section 5.03, an addendum to the Baseline Documentation Report shall be prepared and shall be acknowledged by Grantor and Grantee as memorializing the condition of the Property as of the date the amendment is delivered for recording to the [name of recording office]. Notwithstanding the foregoing, an addendum to the Baseline Documentation Report shall not be required for any amendment that involves solely the correction of a drafting mistake or mapping error.

(e) Costs If Grantor is the party requesting an amendment of this Easement, Grantor shall be responsible for all reasonable and customary costs related to Grantee's evaluation of said request and the amendment's execution, including but not limited to (i) any costs incurred in connection with the requirements of paragraphs 5.03(c)(i) and, if applicable, (ii) any agency or judicial proceeding referred to in Section 5.03(f), including reasonable attorney's fees and staff, contractor, legal, and consultant costs incurred in connection therewith by Grantee, and (iii) any costs associated with the preparation of the updated Baseline Documentation Report prepared pursuant to the provisions of Section 5.03(d).

(f) Court Approval Required A proposed amendment that is agreed to by Grantor and Grantee but nevertheless exceeds the scope of the limited discretion granted under this Section 5.03 is not permitted except by a final non-appealable judgment of a court having jurisdiction in $a$ proceeding to which the Attorney General of the [state] was given written notice and an opportunity to participate to represent the public interest in ensuring the continued perpetual protection of the Conservation Values and the purpose of this Easement. [italicized language is 
optional, but if the state AG is knowledgeable about conservation easement, parties may want to leave it in.]

*As noted, the law on amending conservation easements is unsettled. One of the more difficult issues is the so-called "four corners" question: if you are amending a conservation easement, and, for example, there would be prohibited private economic benefit to the landowner as a result of the proposed amendment, is it permissible to go "outside" the four corners of the easement document (and, in fact, outside the four corners of the property encumbered by the easement), and encumber other property (and take no income tax deduction for same) so there is a net loss of economic value to the landowner. Some would argue that this is tantamount to buying one's way out of a perpetual conservation easement. Others would argue that if there is an important net conservation gain, an easement holder should at least be free to consider such a transaction.

At least as problematic as the "netting" of economic benefit is this: what if the proposed conservation easement amendment has a negative impact on the Conservation Values of the Property under easement (capitalized terms used and defined in the easement document)? Arguably, under Section 170(h) and the regulations, this is prohibited. On these facts, the Conservation Values are not protected in perpetuity. Can a loss of Conservation Values on the eased property be supportable if there is a significant net conservation gain by virtue of easing or gifting other property with important conservation values (that is, outside the four corners)? The answer to that may be "no." So it is quite possible that a proposed amendment that would have an adverse impact on the Conservation Values of the eased property is stopped dead in its tracks, and the landowner cannot "net out" that conservation loss by encumbering or gifting other property 
(and taking no income tax deduction). The provision in paragraph 5.03(c)(ii) text accompanying the asterisk takes that position, that is, if one starts with a proposed amendment that has an adverse impact on the Conservation Values of the eased property, the Easement may not be amended under the provisions included above. However, recognizing that in some rare and unusual cases, a case can be made for netting out a loss of Conservation Values by filling the cup with substantially more protected conservation values (for which no income tax deduction is taken), the reader is referred to paragraph 5.03(f), above. 